\begin{abstract}
UNIVERSIDADE DE SÃO PAULO
FACULDADE DE CIÊNCIAS FARMACÊUTICAS

Programa de Pós-Graduação em Toxicologia e Análises Toxicológicas
\end{abstract}

EFEITOS CITOTÓXICOS, GENOTÓXICOS E EPIGENÉTICOS DO BISFENOL A EM CÉLULAS HL-60, MCF-7 E EM RATOS

André Luiz Teroso Ribeiro

Orientador:

Profa. Dra. Ana Paula de Melo Loureiro

São Paulo

2015 


\begin{abstract}
UNIVERSIDADE DE SÃO PAULO
FACULDADE DE CIÊNCIAS FARMACÊUTICAS

Programa de Pós-Graduação em Toxicologia e Análises Toxicológicas
\end{abstract}

EFEITOS CITOTÓXICOS, GENOTÓXICOS E EPIGENÉTICOS DO BISFENOL A EM CÉLULAS HL-60, MCF-7 E EM RATOS

André Luiz Teroso Ribeiro

Versão Corrigida

Tese para obtenção do Título de DOUTOR

Orientador:

Profa. Dra. Ana Paula de Melo Loureiro

São Paulo

2015 
Ficha Catalográfica

Elaborada pela Divisão de Biblioteca e

Documentação do Conjunto das Químicas da USP.

Ribeiro, André Luiz Teroso

R484e Efeitos citotóxicos, genotóxicos e epigenéticos do bisfenol A em células HL-60, MCF-7 e em ratos / André Luiz Teroso Ribeiro.

-- São Paulo, 2015.

$165 \mathrm{p}$.

Tese (doutorado) - Faculdade de Ciências Farmacêuticas da Universidade de São Paulo. Departamento de Análises Clínicas e Toxicológicas.

Orientador: Loureiro, Ana Paula de Melo

1. Toxicologia ambiental 2. DNA 3. Diabetes I. T. II. Loureiro, Ana Paula de Melo, orientador. 
André Luiz Teroso Ribeiro

\section{EFEITOS CITOTÓXICOS, GENOTÓXICOS E EPIGENÉTICOS DO BISFENOL A EM CÉLULAS HL-60, MCF-7 E EM RATOS}

Comissão Julgadora da Tese para obtenção do Título de DOUTOR

Profa. Dra. Ana Paula de Melo Loureiro

orientador/presidente

$1^{\circ}$. examinador

$2^{\circ}$. examinador

$3^{\circ}$. examinador

$4^{\circ}$. examinador de de 2015. 


\section{APOIO FINANCEIRO}

CAPES: COORDENAÇÃO DE APERFEIÇOAMENTO DE PESSOAL DE NÍVEL SUPERIOR

FAPESP: FUNDAÇÃO DE AMPARO À PESQUISA DO ESTADO DE SÃO PAULO

CNPq: CONSELHO NACIONAL DE DESENVOLVIMENTO CIENTÍFICO E TECNOLÓGICO

PRÓ-REITORIA DE PESQUISA DA UNIVERSIDADE DE SÃO PAULO 


\title{
Dedicatória
}

\section{Dedico este trabalho}

\begin{abstract}
...A Yeshua
Pela vida, pela força para enfrentar os obstáculos da caminhada,e firmar meus passos de maneira justa e perfeita.
\end{abstract}

...A minha mãe, Clarisse

Por ser suporte, por aconselhar,

Pelas orações, Por ser minha mãe sem seu amor e esforço eu não seria ninguém.

...A minha noiva, Laís

Dedico cada página deste trabalho Pela ajuda, pelo suporte, pela parceria

Pela paciência e por literalmente me encher de esperança. 


\section{AGRADECIMENTOS}

\section{Agradeço...}

... A prof Dr $^{a}$ Ana Paula de Melo Loureiro, pelos ensinamentos, pela orientação, por insitar a expansão do meu conhecimento e por me fazer sentir capaz de alcançar mais conhecimento, por dividir seus conhecimentos, pela ajuda nos experimentos e pela compreensão..... Obrigado !!!

... Aos Amigos do Laboratório: Tiago, Anax, Fabiana, Felipe, Larissa, Mariana, Jéssica e João agradeço pela a amizade durante todo o tempo do doutorado, pelos cafés na copa do bloco 13B, pelos memomento de descontração dentro e fora do laboratório, pelas conversas, pelas piadas e pelas risadas, agradeço pela ajuda técnica e intelectual, mesmo nos dias difíceis e pelo companheirismo, vocês ajudaram muito !!! ...Obrigado !!!!!

... Aos amigos da Toxicologia-USP: agradeço as conversas nos corredores, pela ajudar em "emprestar" algum reagente, agradeço a conversa com os professores, que sem duvida ajudaram e demaneira técnica e intelectual ao desenvolvimento deste trabalho... Obrigado !!!!

... Aos amigos do Solar, Daniel (Ted), Hildebrando (Prefeito), Evandro (Somália), Paulo (Masterchef), Fabiano (Pirulito), Douglas (Boleta), Rodrigo (o cara que vai embora de quinta), Daniel (Curió), André (Grilo), aos agregados, e claro a velha guarda (os fundadores) agradeço por serem minha segunda família, por proporcionarem momentos de descontração, pelo "churras" pelos jantares em família, pelo respeito, pela ajuda com o Thor, pela compreensão, pela parceria e por serem amigos. Acredito que meus dias seriam muito monótonos sem vocês... Obrigado !!!!

... Aos Amigos do Jockey Club, Mirtes, Márcia, Regis, Carla, Guilherme, Claudia, Ahsley, Karen, Talita, André, Camila, Wellington, Geisa, Batista, Francisco agradeço pela amizade, pelo conhecimento compartilhado, arrisco a dizer que foi um dos lugares que eu mais ganhei conhecimento até agora, em todos os sentidos, agradeço pelo carinho, pelo respeito, pelos momentos de alegria e de incertezas que compartilhei com cada um de vocês, pelas conversas no "cafezinho" e pelo incentivo, vocês foram muito importantes.... Obrigado !!!!

... Aos Amigos, Rafael Menck de Almeida e Marcelo Macedo, pela amizade e ajuda em inúmeros assuntos, pelo apadrinhamento, pelo apoio, pelos conhecimentos compartilhados, pela parceria Justa e Perfeita... Obrigado!!!! 
... Aos Colaboradores deste trabalho, Prof. Dr. Paolo de Mascio, Prof. Dr. Ricardo Ambrosio Fock, Prof ${ }^{a}$. Dr $r^{a}$. Marisa Helena Gennari de Medeiros, Agradeço pela colaboração em experimento e por ceder seus laboratórios para este trabalho pudesse ser desenvolvido.... Muito Obrigado !!!

... A Todos que de uma maneira ou de outra me auxiliaram na conclusão deste trabalho.... Muito Obrigado !!!! 
"A ciência consiste em substituir o saber que parecia seguro por uma teoria, ou seja, por algo problemático".

José Ortega y Gasset

"Talvez não tenha conseguido fazer o melhor, mas lutei para que o melhor fosse feito. Não sou o que deveria ser, mas Graças a Deus, não sou o que era antes".

Marthin Luther King 


\section{ÍNDICE DE TABELAS}

TABELA 1 - VALORES DE COEFICIENTE DE EXTINÇÃO MOLAR CALCULADOS PARA O ADUTO BPA-GUA. 
ÍNDICE DE FIGURAS

FIGURA 1 - ESTRUTURAS QUÍMICAS DO BISFENOL A (BPA) E DO DIETILESTILBESTROL (DES) …...................................................28

FIGURA 2 - CICLO REDOX ENVOLVENDO QUINONA, SEMI-QUINONA E CATECOL DO BPA

FIGURA 3 - ADUTOS RESULTANTES DA REAÇÃO DE BPA-3,4-QUINONA COM DGUO E DADO 38

FIGURA 4 - CICLO PEROXIDÁSICO DA MPO. ADAPTADO DE HAMPTON ET

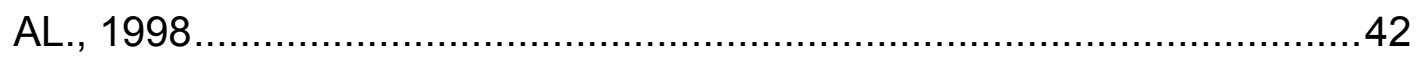

FIGURA 5 - CROMATOGRAMAS OBTIDOS POR HPLC-ESI-MS/MS DE AMOSTRA DE DNA PARA QUANTIFICAÇÃO DE DC, 5-MDC E 5-HMDC 70

FIGURA 6 - CROMATOGRAMA OBTIDO POR HPLC - PDA $(\Lambda=260$ NM) DA REAÇÃO DE BPA COM NITRITO DE SÓDIO EM MEIO ÁCIDO. FOI UTILIZADO O SISTEMA CROMATOGRÁFICO 1. 77

FIGURA 7 - ESPECTROS DE ABSORBÂNCIA E ESPECTROS DE MASSAS NO MODO NEGATIVO (ESI-MS/MS, ÍONS FRAGMENTOS DE M/Z 272 E M/Z 317) DOS PRODUTOS IV E V DA REAÇÃO DE BPA COM NITRITO DE SÓDIO, SENDO INDICADOS OS PRODUTOS IDENTIFICADOS. .....78

FIGURA 8 - (A) CROMATOGRAMA OBTIDO POR HPLC-PDA $(\Lambda=385$ NM) DA REAÇÃO DE BPA COM SAL DE FREMY E ESPECTRO DE ABSORBÂNCIA DO PRODUTO INDICADO (BPA-3,4-QUINONA). (B) ESPECTRO DE MASSAS NO MODO NEGATIVO DO PRODUTO BPA3,4-QUINONA OBTIDO (ESI-MS/MS, ÍONS FRAGMENTOS DE M/Z 241).

FIGURA 9 - (A) CROMATOGRAMA OBTIDO POR HPLC-DAD $(\lambda=275$ NM) DA REAÇÃO DE BPA-3,4-QUINONA COM DGUO, SENDO INDICADO O ADUTO (BPA-GUA) E SEU ESPECTRO DE ABSORBÂNCIA. O PICO INDICADO NÃO APARECEU NAS INCUBAÇÕES CONTROLES; (B) ESPECTRO DE MASSAS DO PRODUTO ISOLADO OBTIDO NO MODO POSITIVO (ESI-MS/MS, ÍONS FRAGMENTOS DE M/Z 394)

FIGURA 10 - ESPECTRO DE 1H RMN DO ADUTO BPA-GUA. ESPECTROS DE RESSONÂNCIA MAGNÉTICA NUCLEAR OBTIDOS DO ADUTO BPAGUA. ESPECTRO DE RMN COM 0,2 MG DE DSS EM $650 \mu \mathrm{L}$ DE VOLUME FINAL.

FIGURA 11 - CROMATOGRAMAS OBTIDOS POR HPLC-ESI-MS/MS DE AMOSTRAS DE DNA DE TIMO DE BEZERRO INCUBADO IN VITRO COM BPA-3,4-QUINONA PARA ANÁLISE DO ADUTO BPA-GUA. A) DNA SUBMETIDO AO PROCEDIMENTO DE HIDRÓLISE NEUTRA-TÉRMICA SEM O PERÍODO DE $1 \mathrm{H}$ DE AQUECIMENTO A $70{ }^{\circ} \mathrm{C}$. B) DNA 
SUBMETIDO AO PROCEDIMENTO COMPLETO DE HIDRÓLISE NEUTRA-TÉRMICA.

FIGURA 12 - VIABILIDADE DAS CÉLULAS HL-60 AVALIADA POR CITOMETRIA DE FLUXO APÓS: (A) $2 \mathrm{H}$ DE INCUBAÇÃO COM AS CONCENTRAÇÕES INDICADAS DE BPA, COM E SEM $\mathrm{H}_{2} \mathrm{O}_{2}$ (40 NMOL/5 $X 10^{4}$ CÉLULAS); (B) $24 \mathrm{H}$ DE INCUBAÇÃO COM AS CONCENTRAÇÕES INDICADAS DE BPA, COM E SEM $\mathrm{H}_{2} \mathrm{O}_{2}$ (40 NMOL/5 X $10^{4}$ CÉLULAS); (C) $48 \mathrm{H}$ DE INCUBAÇÃO COM AS CONCENTRAÇÕES INDICADAS DE BPA, COM E SEM $\mathrm{H}_{2} \mathrm{O}_{2}\left(40 \mathrm{NMOL} / 5 \times 10^{4}\right.$ CÉLULAS). MÉDIA \pm DESVIO PADRÃO KRUSKAL WALLIS COM PÓS TESTE DE DUNN, DIFERENÇAS EM RELAÇÃO AO RESPECTIVO CONTROLE. ${ }^{*} \mathrm{P}<0.05$; ${ }^{* *} \mathrm{P}<0.01$; ${ }^{* * *} P<0.001$. .88

FIGURA 13 - VIABILIDADE DAS CÉLULAS HL-60 AVALIADA POR CITOMETRIA DE FLUXO APÓS: (A) $2 \mathrm{H}$ DE INCUBAÇÃO COM AS CONCENTRAÇÕES INDICADAS DE BPANO ${ }_{2}$, COM E SEM $\mathrm{H}_{2} \mathrm{O}_{2}(40$ NMOL/5 X $10^{4}$ CÉLULAS); (B) $24 \mathrm{H}$ DE INCUBAÇÃO COM AS CONCENTRAÇÕES INDICADAS DE BPANO ${ }_{2}, \mathrm{COM} \mathrm{E} \mathrm{SEM} \mathrm{H}_{2} \mathrm{O}_{2}(40$ NMOL/5 X $10^{4}$ CÉLULAS). (C) $48 \mathrm{H}$ DE INCUBAÇÃO COM AS CONCENTRAÇÕES INDICADAS DE BPANO ${ }_{2}, \mathrm{COM}$ E SEM $\mathrm{H}_{2} \mathrm{O}_{2}(40$ NMOL/5 X $10^{4}$ CÉLULAS). $N=4$, MÉDIA \pm DESVIO PADRÃO, KRUSKAL WALLIS COM PÓS TESTE DE DUNN, DIFERENÇAS EM RELAÇÃO AO RESPECTIVO CONTROLE. *P<0.05; ${ }^{* *} P<0.01$.

FIGURA 14 - CONSUMO DE BPA PELAS CÉLULAS HL-60. AS CÉLULAS FORAM CULTIVADAS NA DENSIDADE DE $2,4 \times 10^{6}$ (A) OU $1 \times 10^{7}(B)$ CÉLULAS POR POÇO E EXPOSTAS A $250 \mathrm{MM}$ DE BPA. ALÍQUOTAS DO MEIO DE CULTURA FORAM RETIRADAS NOS PERÍODOS INDICADOS PARA QUANTIFICAÇÃO DE BPA POR HPLC-DAD $(\lambda=277$ NM).

FIGURA 15 - VIABILIDADE DAS CÉLULAS HL-60 AVALIADA PELO ENSAIO DO XTT APÓS $24 \mathrm{H}$ DE INCUBAÇÃO COM AS CONCENTRAÇÕES INDICADAS DE BPA E BPANO ${ }_{2}$, COM E SEM $\mathrm{H}_{2} \mathrm{O}_{2}\left(40 \mathrm{NMOL} / 5 \times 10^{4}\right.$ CÉLULAS). , MÉDIA \pm DESVIO PADRÃO, , KRUSKAL WALLIS COM PÓS TESTE DE DUNN, DIFERENÇAS EM RELAÇÃO AO RESPECTIVO CONTROLE. ${ }^{*} P<0.05 ;{ }^{* * *} P<0.001$.

FIGURA 16 - FLUORESCÊNCIA RELATIVA (\%) DO PRODUTO DCF NAS CÉLULAS HL-60 APÓS $1 \mathrm{H}$ DE INCUBAÇÃO (A) COM AS CONCENTRAÇÕES INDICADAS DE BPA COM E SEM $\mathrm{H}_{2} \mathrm{O}_{2}(40 \mathrm{NMOL} / 5$ $X 10^{4}$ CÉLULAS). (B) COM AS CONCENTRAÇÕES INDICADAS DE BPANO $_{2}$ COM E SEM $\mathrm{H}_{2} \mathrm{O}_{2}\left(40 \mathrm{NMOL} / 5 \times 10^{4}\right.$ CÉLULAS). $\mathrm{N}=4$, MÉDIA \pm DESVIO PADRÃO, KRUSKAL WALLIS COM PÓS-TESTE DE DUNN, DIFERENÇAS EM RELAÇÃO AO RESPECTIVO CONTROLE. ${ }^{*} \mathrm{P}<0.05$; ${ }^{* *} P<0.01$. .94

FIGURA 17 - GERAÇÃO DE NITRITO PELAS CÉLULAS HL-60 APÓS: (A) $2 \mathrm{H}$ DE INCUBAÇÃO COM AS CONCENTRAÇÕES INDICADAS DE BPA, 
SEM E COM $\mathrm{H}_{2} \mathrm{O}_{2}\left(40 \mathrm{NMOL} / 5 \times 10^{4}\right.$ CÉLULAS); (B) $24 \mathrm{H}$ DE INCUBAÇÃO COM AS CONCENTRAÇÕES INDICADAS DE BPA, SEM E COM $\mathrm{H}_{2} \mathrm{O}_{2}\left(40 \mathrm{NMOL} / 5 \times 10^{4}\right.$ CÉLULAS), MÉDIA \pm DESVIO PADRÃO, KRUSKAL WALLIS COM PÓS TESTE DE DUNN, DIFERENÇAS EM RELAÇÃO AO RESPECTIVO CONTROLE. * $P<0.05$; ${ }^{* *} P<0.01 \ldots \ldots \ldots \ldots . . .96$ FIGURA 18 - ATIVIDADE DE MPO DAS CÉLULAS HL-60 APÓS: (A) 2 H DE INCUBAÇÃO COM AS CONCENTRAÇÕES INDICADAS DE BPA, COM E SEM $\mathrm{H}_{2} \mathrm{O}_{2}$ (40 NMOL/5 X $10^{4}$ CÉLULAS); (B) $24 \mathrm{H}$ DE INCUBAÇÃO COM AS CONCENTRAÇÕES INDICADAS DE BPA, COM E SEM $\mathrm{H}_{2} \mathrm{O}_{2}(40$ NMOL/5 X $10^{4}$ CÉLULAS), MÉDIA \pm DESVIO PADRÃO, KRUSKAL WALLIS COM PÓS TESTE DE DUNN, DIFERENÇAS EM RELAÇÃO AO RESPECTIVO CONTROLE. 97

FIGURA 19 - CROMATOGRAMA RESPRESENTATIVO DA ANÁLISE DE MDA EM MEIO DE CULTURA. O PICO INDICADO É O PRODUTO DE REAÇÃO DO MDA PRESENTE NA AMOSTRA COM DINITROFENILHIDRAZINA (DNPH), EMPREGADO COMO AGENTE DERIVATIZANTE. .98

FIGURA 20 - CONCENTRAÇÃO DE MDA NO MEIO DE CULTURA DAS CÉLULAS HL-60 APÓS $24 \quad \mathrm{H}$ DE INCUBAÇÃO COM AS CONCENTRAÇÕES INDICADAS DE BPA, SEM E COM H $\mathrm{H}_{2} \mathrm{O}_{2}(40 \mathrm{NMOL} / 5$ $X 10^{4}$ CÉLULAS). $\mathrm{N}=4$, MÉDIA \pm DESVIO PADRÃO, KRUSKAL WALLIS COM PÓS-TESTE DE DUNN. 98

FIGURA 21 - FRAGMENTAÇÃO DO DNA DAS CÉLULAS HL-60 AVALIADA POR CITOMETRIA DE FLUXO APÓS $24 \mathrm{H}$ DE INCUBAÇÃO COM AS CONCENTRAÇÕES INDICADAS DE BPA (A) E BPANO 2 (B), COM E SEM $\mathrm{H}_{2} \mathrm{O}_{2}$ (40 NMOL/5 $\times 10^{4}$ CÉLULAS). $\mathrm{N}=4$, MÉDIA \pm DESVIO PADRÃO, KRUSKAL WALLIS COM PÓS TESTE DE DUNN, DIFERENÇAS EM RELAÇÃO AO RESPECTIVO CONTROLE. ${ }^{*} P<0.05 ;{ }^{* *} P<0.01$. 99

FIGURA 22 - FRAGMENTAÇÃO DO DNA DAS CÉLULAS HL-60 AVALIADA POR CITOMETRIA DE FLUXO APÓS $24 \mathrm{H}$ DE INCUBAÇÃO COM AS CONCENTRAÇÕES INDICADAS DE BPA (A) E BPANO 2 (B), COM E SEM $\mathrm{H}_{2} \mathrm{O}_{2}$ (40 NMOL/5 X $10^{4}$ CÉLULAS). $\mathrm{N}=4$, MÉDIA \pm DESVIO PADRÃO, KRUSKAL WALLIS COM PÓS TESTE DE DUNN, DIFERENÇAS EM RELAÇÃO AO RESPECTIVO CONTROLE. ${ }^{*}<<0.05 ;{ }^{* *} \mathrm{P}<0.01$. 100

FIGURA 23 - CROMATOGRAMAS OBTIDOS POR HPLC-ESI-MS/MS DE AMOSTRAS DE DNA DE FÍGADO DE RATOS SPRAGUE-DAWLEY PARA ANÁLISE DO ADUTO BPA-GUA. A) CONTROLE; B) BPA, GAVAGEM, 50 MG/KG/DIA, 4 SEMANAS; C) DIABÉTICOS + BPA (GAVAGEM, 50 $M G / K G / D I A, 4$ SEMANAS). 104

FIGURA 24 - NÍVEIS DE CEDG E 8-OXODG EM DNA DE CÉLULAS HL-60 INCUBADAS COM BPA COM OU SEM $\mathrm{H}_{2} \mathrm{O}_{2}$ (40 NMOL/5X104 CÉLULAS), NAS CONCENTRAÇÕES INDICADAS POR 24 HORAS. ANÁLISE ESTATÍSTICA UTILIZANDO O TESTE DE KRUSKAL WALLIS COM PÓS 
TESTE DE DUNN NÃO MOSTROU DIFERENÇA ENTRE OS GRUPOS. 105

FIGURA 25 - NÍVEIS DE CEDG E 8-OXODG NO MEIO DE CULTURA (MEIO RPMI SUPLEMENTADO COM 10\% DE SFB) DE CÉLULAS HL-60 INCUBADAS COM BPA, COM E SEM $\mathrm{H}_{2} \mathrm{O}_{2}$ (40 NMOL/5X104 CÉLULAS), NAS CONCENTRAÇÕES INDICADAS POR 24 HORAS. ANÁLISE ESTATÍSTICA UTILIZANDO O TESTE DE KRUSKAL WALLIS COM PÓS TESTE DE DUNN NÃO MOSTROU DIFERENÇA ENTRE GRUPOS. ....106 FIGURA 26 - NÍVEIS DE CEDG E 8-OXODG EM DNA DE CÉLULAS HL-60 INCUBADAS COM BPANO 2 , COM E SEM $\mathrm{H}_{2} \mathrm{O}_{2}$ (40 NMOL/5X10 4 CÉLULAS), NAS CONCENTRAÇÕES INDICADAS PELO PERÍODO DE 24 HORAS. *P<0,05 EM COMPARAÇÃO COM O CONTROLE, DE ACORDO COM O TESTE DE KRUSKAL WALLIS COM PÓS TESTE DE DUNN...108 FIGURA 27 - NÍVEIS DE 5-MDC E 5-HMDC EM DNA DE CÉLULAS HL-60 INCUBADAS COM BPA, SEM E COM $\mathrm{H}_{2} \mathrm{O}_{2}$ (40 NMOL/5 X $10^{4}$ CÉLULAS), NAS CONCENTRAÇÕES INDICADAS POR $24 \mathrm{H}$. * $\mathrm{P}<0,05$, ${ }^{* *} \mathrm{P}<0,01$ COMPARANDO-SE OS DIFERENTES GRUPOS COM O CONTROLE, DE ACORDO COM TESTE DE KRUSKAL WALLIS COM PÓS TESTE DE DUNN.

FIGURA 28 - VIABILIDADE DAS CÉLULAS MCF-7 AVALIADA POR CITOMETRIA DE FLUXO APÓS: A) $1 \mathrm{H}$ DE INCUBAÇÃO COM AS CONCENTRAÇÕES INDICADAS DE BPA; B) 24 H DE INCUBAÇÃO COM AS CONCENTRAÇÕES INDICADAS DE BPA, MÉDIA \pm DESVIO PADRÃO, KRUSKAL WALLIS COM PÓS TESTE DE DUNN, DIFERENÇAS EM RELAÇÃO AO CONTROLE..................................116 FIGURA 29 - VIABILIDADE DAS CÉLULAS MCF-7 AVALIADA POR CITOMETRIA DE FLUXO APÓS: A) $1 \mathrm{H}$ DE INCUBAÇÃO COM AS CONCENTRAÇÕES INDICADAS DE BPANO ${ }_{2}$; B) $24 \mathrm{H}$ DE INCUBAÇÃO COM AS CONCENTRAÇÕES INDICADAS DE BPANO ${ }_{2} . \mathrm{N}=4$, MÉDIA \pm DESVIO PADRÃO, TESTE DE KRUSKAL WALLIS COM PÓS TESTE DE DUNN, DIFERENÇAS EM RELAÇÃO AO CONTROLE. ${ }^{*} \mathrm{P}<0.05$; ${ }^{* *} \mathrm{P}<0.01$. 116

FIGURA 30 - FLUORESCÊNCIA RELATIVA (\%) DO PRODUTO DCF NAS CÉLULAS MCF-7 APÓS A) $1 \mathrm{H}$ DE INCUBAÇÃO COM AS CONCENTRAÇÕES INDICADAS DE BPA E BPANO ${ }_{2}$; B) $24 \mathrm{H}$ DE INCUBAÇÃO COM AS CONCENTRAÇÕES INDICADAS DE BPA E $\mathrm{BPANO}_{2} . \mathrm{N}=4, \mathrm{MÉDIA} \pm$ DESVIO PADRÃO, KRUSKAL WALLIS COM PÓS TESTE DE DUNN, DIFERENÇAS EM RELAÇÃO AO CONTROLE. ${ }^{*}<0,05$.

FIGURA 31 - FRAGMENTAÇÃO DO DNA DAS CÉLULAS MCF-7 AVALIADA POR CITOMETRIA DE FLUXO APÓS $24 \mathrm{H}$ DE INCUBAÇÃO COM AS CONCENTRAÇÕES INDICADAS DE BPA (A) E BPANO ${ }_{2}$ (B). $\mathrm{N}=4$, MÉDIA \pm DESVIO PADRÃO, KRUSKAL WALLIS COM PÓS TESTE DE DUNN, DIFERENÇAS EM RELAÇÃO AO CONTROLE. ${ }^{* *} P<0.01$ 118 
FIGURA 32 - CICLO DAS CÉLULAS MCF-7 AVALIADO POR CITOMETRIA DE FLUXO APÓS $24 \mathrm{H}$ DE INCUBAÇÃO COM AS CONCENTRAÇÕES INDICADAS DE BPA (A) E BPANO ${ }_{2}$ (B). $N=4$, MÉDIA \pm DESVIO PADRÃO, KRUSKAL WALLIS COM PÓS TESTE DE DUNN, DIFERENÇAS EM RELAÇÃO AO CONTROLE. ${ }^{*} P<0.05 ; \quad{ }^{* *} P<0.01$; ${ }^{* * *} P<0.001$.

FIGURA 33 - (A) ATIVIDADE ETOXIRRESORUFINA-O-DEETILASE DAS CÉLULAS MCF-7 INCUBADAS COM AS CONCENTRAÇÕES INDICADAS DE PCB POR $24 \mathrm{H}$; B) CONSUMO DE BPA PELAS CÉLULAS MCF-7. AS CÉLULAS FORAM CULTIVADAS NA DENSIDADE DE $2,4 \times 10^{6}$ CÉLULAS POR POÇO, INCUBADAS COM 300 NM DE PCB POR $24 \mathrm{H} \mathrm{E}$, APÓS TROCA DO MEIO DE CULTURA, INCUBADAS COM BPA NAS CONCENTRAÇÕES INDICADAS. ALÍQUOTAS DO MEIO DE CULTURA FORAM RETIRADAS NOS TEMPOS INDICADOS PARA QUANTIFICAÇÃO DE BPA POR HPLC-DAD $(\lambda=277 \mathrm{NM})$ 120 FIGURA 34 - (A) NÍVEIS DE CEDG E 8-OXODG EM DNA DE CÉLULAS MCF7 INCUBADAS COM BPA NAS CONCENTRAÇÕES INDICADAS POR 24 H. (B) NÍVEIS DE CEDG E 8-OXODG EM DNA DE CÉLULAS MCF-7 INCUBADAS COM 300 NM DE PCB POR 24 H PARA AUMENTO DA ATIVIDADE ETOXIRRESORUFINA-O-DEETILASE E, APÓS TROCA DO MEIO DE CULTURA, INCUBADAS COM BPA NAS CONCENTRAÇÕES INDICADAS POR $24 \mathrm{H}$. ${ }^{*} \mathrm{P}<0,05,{ }^{* *} \mathrm{P}<0,01$ COMPARANDO-SE OS DIFERENTES GRUPOS COM O CONTROLE, DE ACORDO COM TESTE DE KRUSKAL WALLIS COM PÓS TESTE DE DUNN.

FIGURA 35 - (A) NÍVEIS DE CEDG E 8-OXODG NO MEIO DE CULTURA DE CÉLULAS MCF-7 INCUBADAS COM BPA. (B) NÍVEIS DE CEDG E 8OXODG NO MEIO DE CULTURA DE CÉLULAS MCF-7 INCUBADAS COM 300 NM DE PCB 126 POR 24 H PARA AUMENTO DA ATIVIDADE ETOXIRRESORUFINA-O-DEETILASE E, APÓS TROCA DO MEIO DE CULTURA, INCUBADAS COM BPA NAS CONCENTRAÇÕES INDICADAS POR $24 \mathrm{H}$. ANÁLISE ESTATÍSTICA UTILIZANDO O TESTE DE KRUSKAL WALLIS COM PÓS TESTE DE DUNN NÃO MOSTROU DIFERENÇA ENTRE OS GRUPOS 124

FIGURA 36 - NÍVEIS DE CEDG E 8-OXODG EM DNA DE CÉLULAS MCF-7 INCUBADAS COM BPANO 2 NAS CONCENTRAÇÕES INDICADAS POR $24 \mathrm{H}$. ANÁLISE ESTATÍSTICA UTILIZANDO O TESTE DE KRUSKAL WALLIS COM PÓS TESTE DE DUNN NÃO MOSTROU DIFERENÇA ENTRE OS GRUPOS

FIGURA 37 - (A) NÍVEIS DE 5-MDC E 5-HMDC EM DNA DE CÉLULAS MCF-7 INCUBADAS COM BPA NAS CONCENTRAÇÕES INDICADAS POR $24 \mathrm{H}$. (B) NÍVEIS DE 5-MDC E 5-HMDC EM DNA DE CÉLULAS MCF-7 INCUBADAS COM 300 NM DE PCB POR 24 H PARA AUMENTO DA ATIVIDADE ETOXIRRESORUFINA-O-DEETILASE E, APÓS TROCA DO MEIO DE CULTURA, INCUBADAS COM BPA NAS CONCENTRAÇÕES 
INDICADAS POR $24 \mathrm{H}$. (C) NÍVEIS DE 5-MDC E 5-HMDC EM DNA DE CÉLULAS MCF-7 INCUBADAS COM BPANO ${ }_{2} \mathrm{NAS}$ CONCENTRAÇÕES INDICADAS POR $24 \mathrm{H}$ * $\mathrm{P}<0,05$ COMPARANDO-SE OS DIFERENTES GRUPOS COM O CONTROLE, DE ACORDO COM TESTE DE KRUSKAL WALLIS COM PÓS TESTE DE DUNN.

FIGURA 38 - PERFIL GLICÊMICO DOS ANIMAIS EXPOSTOS AO BPA DURANTE 4 SEMANAS. A GLICEMIA FOI VERIFICADA A CADA SEMANA. OS ANIMAIS FORAM CONSIDERADOS DIABÉTICOS COM GLICEMIA ACIMA DE $250 \mathrm{MG} / \mathrm{DL}$. OS RESULTADOS EXPRESSAM A MÉDIA \pm DESVIO PADRÃO; OS GRUPOS DIABÉTICOS COM OU SEM BPA APRESENTARAM P<0,001, PETO TESTE ONE WAY ANOVA, COM RELAÇÃO AOS ANIMAIS SADIOS COM E SEM BPA.

FIGURA 39 - PERFIL DO GANHO DE PESO DE RATOS SPRAGUE-DAWLEY EXPOSTOS AO BPA POR VIA INTRAGASTRICA. OS ANIMAIS FORAM EXPOSTOS DURANTE 4 SEMANAS AO BPA NA CONCENTRAÇÃO DE $50 \mathrm{MG} / K G$ DE PESO CORPÓREO. OS RESULTADOS EXPRESSAM A MÉDIA \pm DESVIO PADRÃO.

FIGURA 40 - HEMOGRAMA DE RATOS SPRAGUE-DAWLEY EXPOSTOS A BPA (50 MG/KG P.C.) NA VIGÊNCIA OU AUSÊNCIA (SADIOS) DE DIABETES. (A) ERITRÓCITOS CIRCULANTES; (B) HEMOGLOBINA; (C) LEUCÓCITOS CIRCULANTES; (D) PORCENTAGEM DO HEMATÓCRITOS. GRUPOS SADIOS ( $N=5$ ), GRUPOS DIABÉTICOS ( $N$ $=10)$, MÉDIA \pm DESVIO PADRÃO, TESTE T DE STUNDENT, DIFERENÇAS EM RELAÇÃO AO RESPECTIVO CONTROLE (VEÍCULO). ${ }^{*} \mathrm{P}<0,05$

FIGURA 41 - MIELOGRAMA DE RATOS SPRAGUE-DAWLEY EXPOSTOS A BPA (50 MG/KG P.C.) NA VIGÊNCIA OU AUSÊNCIA (SADIOS) DE DIABETES. (A) NÚMERO TOTAL DE CÉLULAS DO LAVADO MEDULAR DO FÊMUR; (B) EOSINÓFILOS; (C) LINFÓCITOS; (D) PROMIELÓCITOS; (E) BLASTOS; (F) BASTONETES; (G) SEGMENTADOS; (H) BASÓFILOS; (I) PLASMÓCITOS; (J) MONÓCITOS; (K) ERITROBLASTOS JOVENS; (L) ERITROBLASTOS POLICROMÁTICOS; (M) ERITROBLASTOS ORTOCROMÁTICOS. GRUPOS SADIOS ( $\mathrm{N}=5$ ), GRUPOS DIABÉTICOS $(N=10)$, MÉDIA \pm DESVIO PADRÃO, TESTE T DE STUNDENT, DIFERENÇAS EM RELAÇÃO AO RESPECTIVO CONTROLE (VEÍCULO). ${ }^{*} \mathrm{P}<0,05,{ }^{* *} \mathrm{P}<0,01$

FIGURA 42 - NÍVEIS DE 8-OXODG, CEDG, O6-MDG E 1,N6EDA EM URINA DOS RATOS DOS DIFERENTES GRUPOS EXPERIMENTAIS. A) CONCENTRAÇÃO NA URINA DE $10 \mathrm{H}$ (PG/ML). B) NÍVEIS TOTAIS EXCRETADOS EM $10 \mathrm{H}(\mathrm{PG} / 10 \mathrm{H})$. ${ }^{*} \mathrm{P}<0,05,{ }^{* *} \mathrm{P}<0,01$ COMPARANDOSE OS DIFERENTES GRUPOS COM O CONTROLE, DE ACORDO COM TESTE DE KRUSKAL WALLIS COM PÓS TESTE DE DUNN. 136 
FIGURA 43 - CROMATOGRAMAS OBTIDOS POR HPLC-ESI-MS/MS DE AMOSTRA DE URINA DE RATO PARA QUANTIFICAÇÃO DOS ADUTOS INDICADOS.

FIGURA 44 - NÍVEIS DE CEDG, 8-OXODG E O6-MDG EM DNA DE FÍGADO DOS RATOS DOS DIFERENTES GRUPOS EXPERIMENTAIS. ${ }^{*} P<0,05$ COMPARANDO-SE OS DIFERENTES GRUPOS COM O CONTROLE, DE ACORDO COM TESTE DE KRUSKAL WALLIS COM PÓS TESTE DE DUNN. 138

FIGURA 45 - NÍVEIS DE CEDG, 8-OXODG E $0^{6}$-MDG EM DNA DE RIM DOS RATOS DOS DIFERENTES GRUPOS EXPERIMENTAIS. *P $<0,05$ EM COMPARAÇÃO COM O GRUPO BPA, ${ }^{* *} P<0,01,{ }^{* * *} P<0,001 \quad$ EM COMPARAÇÃO COM O GRUPO CONTROLE, DE ACORDO COM TESTE DE KRUSKAL WALLIS COM PÓS TESTE DE DUNN.

FIGURA 46 - NÍVEIS DE 5-MDC E 5-HMDC EM DNA DE FÍGADO DE RATOS DOS DIFERENTES GRUPOS EXPERIMENTAIS *P $<0,05$ COMPARANDO-SE OS DIFERENTES GRUPOS COM O CONTROLE, DE ACORDO COM TESTE DE KRUSKAL WALLIS COM PÓS TESTE DE DUNN.

FIGURA 47 - NÍVEIS DE 5-MDC E 5-HMDC EM DNA DE RIM DOS RATOS DOS DIFERENTES GRUPOS EXPERIMENTAIS. ANÁLISE ESTATÍSTICA UTILIZANDO O TESTE DE KRUSKAL WALLIS COM PÓS TESTE DE DUNN NÃO MOSTROU DIFERENÇA ENTRE OS GRUPOS. 142 


\section{SUMÁRIO}

RESUMO

ABSTRACT 23

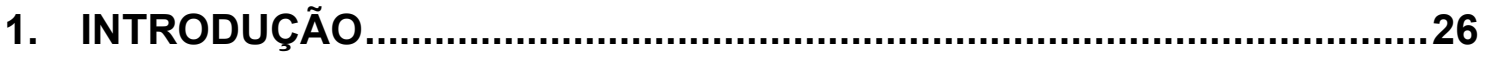

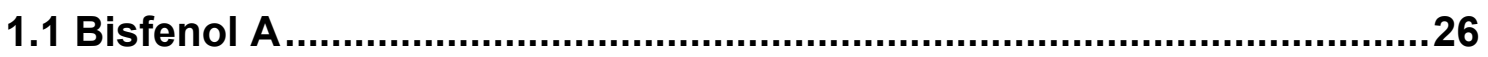

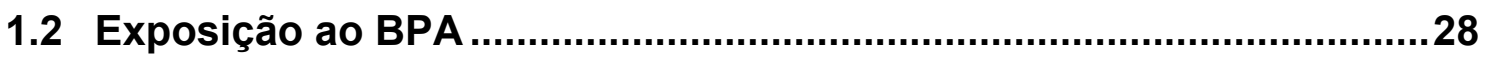

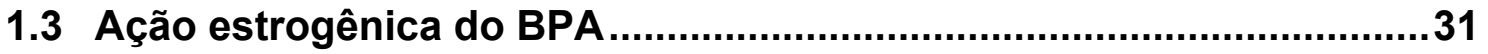

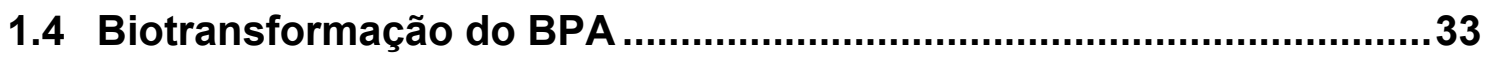

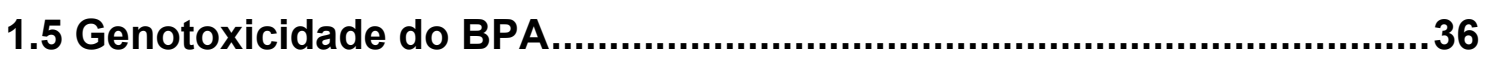

2 OBJETIVOS

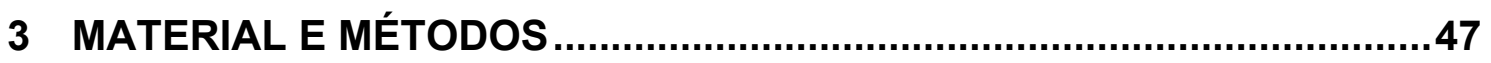

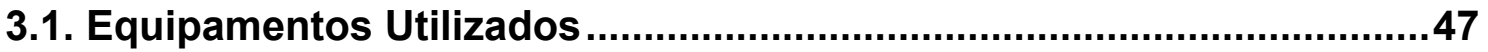

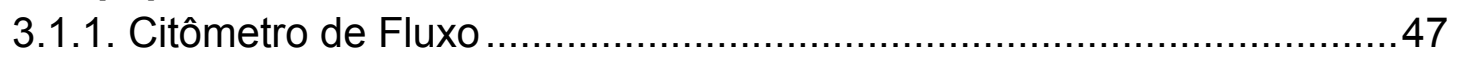

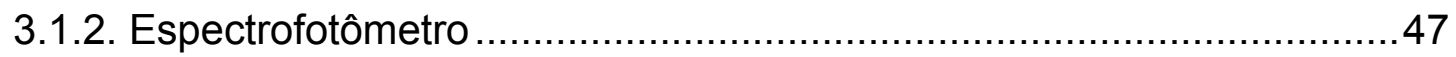

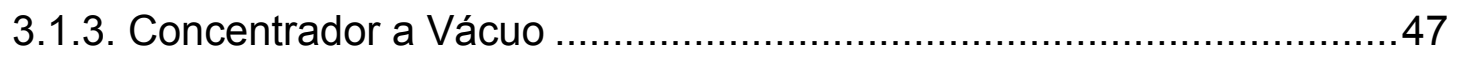

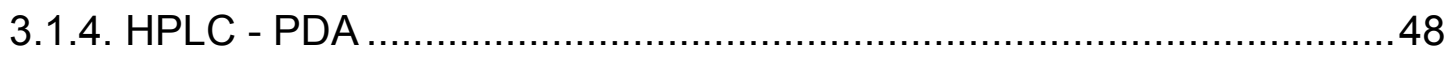

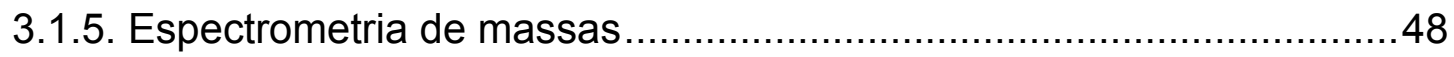

3.2. Condições Cromatográficas.................................................................49

3.3. Síntese de 3-nitro-bisfenol A $\left(\mathrm{BPANO}_{2}\right)$ e 3,3'-dinitro-bisfenol A

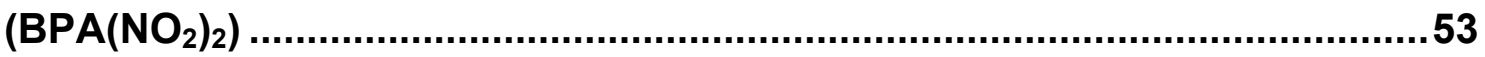

3.4. Síntese de bisfenol A-3,4-quinona (BPA-3,4-quinona) ........................53

3.5. Síntese do aduto de BPA-3,4-quinona com 2'-desoxiguanosina (dGuo)

3.6 Quantificação do aduto BPA-Gua em DNA ………............................55

3.7. Curva de crescimento das linhagens celulares HL-60 e MCF-7 ...........56

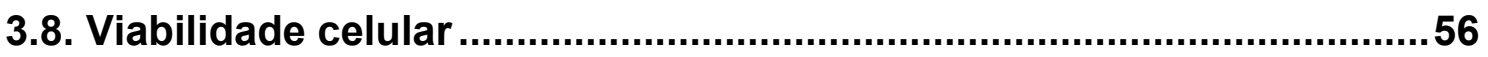

3.9. Ensaio do XTT 
3.10. Determinação da geração intracelular de espécies reativas de oxigênio (ERO) e nitrogênio (ERN)

3.11. Determinação de $\mathrm{NO}_{2}$ - no meio de cultura das células $\mathrm{HL}-60 \ldots \ldots \ldots . . . .60$

3.12. Análise de fragmentação do DNA e ciclo celular ................................60

3.13. Determinação da atividade de MPO em células HL-60 ......................61

3.14. Ensaio EROD para verificação da atividade de CYP1A1 em células MCF-7.

3.15. Análises da concentração de BPA no meio de cultura das células ..63

3.16. Quantificação de malonaldeído no meio de cultura por HPLC-PDA.63

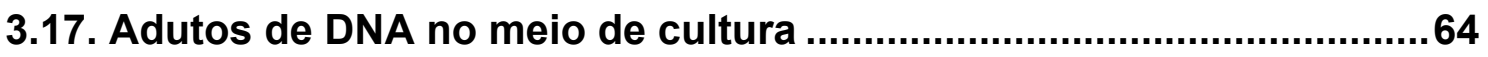

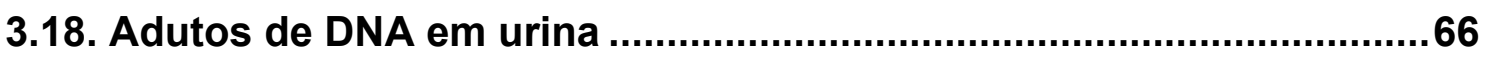

3.19. Extração de DNA das células ............................................................66

3.20. Extração de DNA de fígado e rim dos animais .....................................67

3.21. Quantificação de 8-oxodG e CEdG em amostras de DNA...................68

3.22. Quantificação de 5-metil-2'-desoxicitidina (5-metildC) e 5hidroximetil-2'-desoxicitidina (5-hmdC) em DNA .......................................69

3.23. Exposição de ratos ao BPA na vigência e ausência de doença inflamatória sistêmica ..............................................................................70

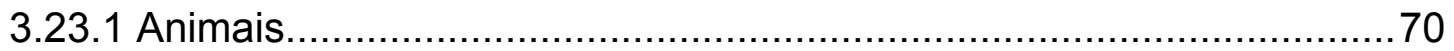

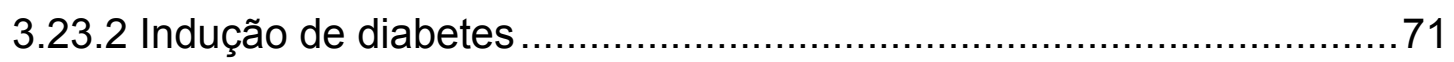

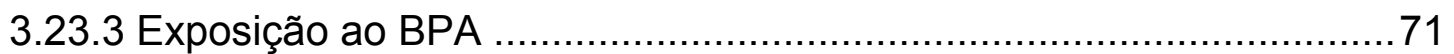

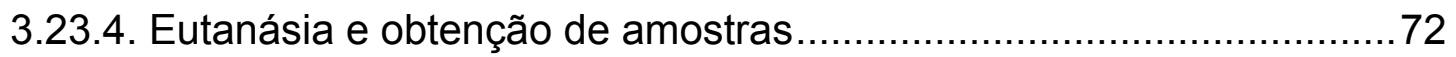

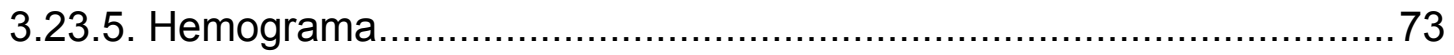

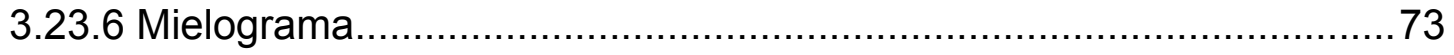

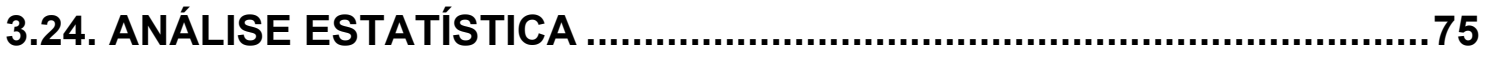

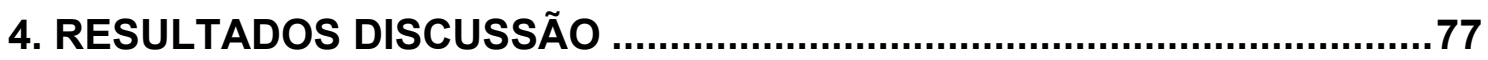

4.1. SÍNTESE E CARACTERIZAÇÃO DAS MOLÉCULAS UTILIZADAS

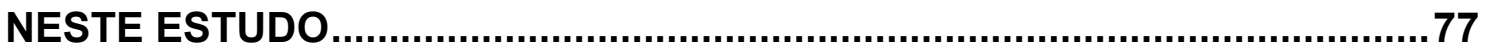

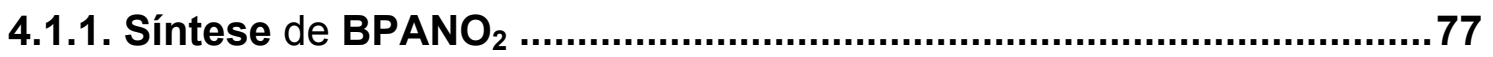

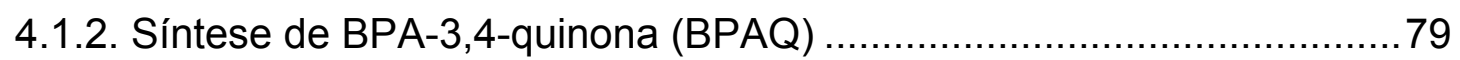


4.1.3. Síntese do aduto de BPA-3,4-quinona com guanina (Gua)

4.2. Padronização do método de hidrólise do DNA para quantificação do

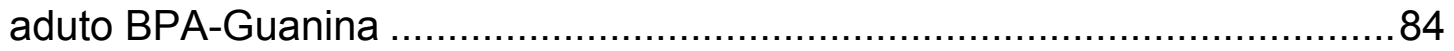

4.3.1. Avaliação da citotoxicidade em células HL-60 ..................................86

4.3.2. Avaliação de efeitos genotóxicos em células HL-60 …....................103

4.3.3. Avaliação de efeitos epigenéticos em células HL-60.......................109

4.4.1. Avaliação da citotoxicidade em células MCF-7 ...............................115

4.4.2. Avaliação de efeitos genotóxicos em células MCF-7 ….................121

4.4.3. Avaliação de efeitos epigenéticos em células MCF-7 .......................125

4.5.1. Caracterização do modelo experimental..........................................128

4.5.2. Alterações no hemograma e mielograma .........................................130

4.5.3. Níveis de adutos de DNA na urina .................................................134

4.5.4. Efeitos genotóxicos e epigenéticos em fígado e rim........................138

6. CONCLUSÃO

7. REFERÊNCIAS

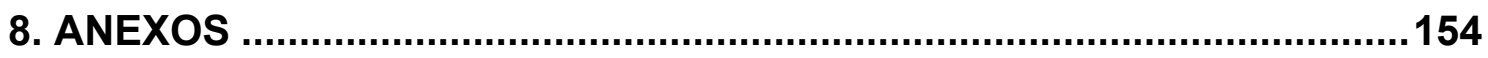

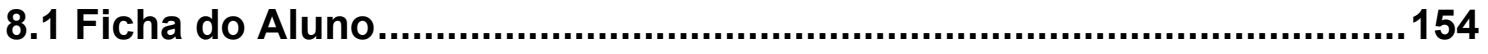

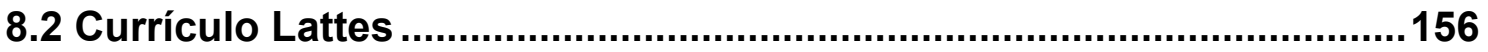

8.3 Intrusções para os membros da banca................................................164

8.4. Certificado da Comissão de Ética no Uso de Animais (CEUA) da FCFUSP 


\section{Resumo}

RIBEIRO, A. L. T. Efeitos Citotóxicos, Genotóxicos e Epigenéticos do Bisfenol A em Células HL60, MCF-7 e em Ratos. 2015. 162f. Tese (Doutorado) - Faculdade de Ciências Farmacêuticas, Universidade de São Paulo, São Paulo, 2015.

Bisfenol A (BPA) é um insumo largamente utilizado na produção de plástico policarbonato e amplamente difundido no meio ambiente, levando o ser humano à exposição crônica desde o período intrauterino. A literatura aponta a possibilidade de BPA aumentar o risco de diversos tipos de câncer, mas são necessários estudos que possibilitem o entendimento de mecanismos pelos quais isso pode ocorrer. Neste trabalho foram investigados os efeitos do BPA ou nitro-BPA em células HL-60, MCF-7 e tecidos de ratos.

Células HL-60 foram expostas ao BPA ou nitro-BPA nas concentrações de 25, 100 e $250 \mu \mathrm{M}(0,1 \%$ DMSO v/v) por 2, 24 ou 48 horas na presença ou ausência de $\mathrm{H}_{2} \mathrm{O}_{2}$ (40 nmol/5 $\times 10^{4}$ células). Células MCF-7 foram expostas da mesma forma, sem o uso de $\mathrm{H}_{2} \mathrm{O}_{2}$, mas na presença e ausência de agonista (PCB) de receptor Ah. Ratos Sprague-Dawley machos receberam BPA diariamente ao longo de 4 semanas (50 $\mathrm{mg} / \mathrm{kg}$ de peso corpóreo) por gavagem, na vigência e ausência de diabetes, com subsequente coleta de urina, fígado, rins, medula óssea e sangue. Nos experimentos com as células, a viabilidade, ciclo celular, fragmentação do DNA e a produção intracelular de espécies reativas de oxigênio (ROs) foram avaliadas por citometria de fluxo, a atividade da cadeia respiratória mitocondrial pelo ensaio do XTT, e a atividade de MPO de células HL-60 por ensaio de fluorescência, bem como a produção de ${ }^{\bullet} \mathrm{NO}$. A metilação e hidroximetilação global do DNA e os adutos 8-oxodG, CEdG, 1, $N^{6}-\varepsilon d A$, $1, N^{2}-\varepsilon d G$ e BPA-Gua no DNA das células, tecidos, meio de cultura e urina foram analisados por HPLC-ESI-MS/MS. O hemograma e mielograma dos animais foram obtidos no Laboratório de Hematologia Experimental da FCF USP.

Observou-se que tanto BPA quanto nitro-BPA induziram a geração de ROS em células HL-60 logo após $2 \mathrm{~h}$ de incubação. BPA levou subsequentemente à perda de atividade da cadeia respiratória mitocondrial, aumento da permeabilidade da membrana plasmática, fragmentação do DNA, parada na fase G2/M do ciclo celular e hipermetilação acompanhada de hipohidroximetilação global do DNA. A citotoxicidade induzida pelas mesmas concentrações de nitro-BPA em células HL-60 foi menos pronunciada, sem perda de atividade da cadeia respiratória mitocondrial, com pouca fragmentação do DNA, mas com parada na fase G0/G1 do ciclo celular e indução de hipohidroximetilação global do DNA na presença de $\mathrm{H}_{2} \mathrm{O}_{2}$. Não foi observada a indução de adutos de DNA nas células HL-60 incubadas com BPA, mas sim de CEdG nas células incubadas com nitro-BPA.

Os dados obtidos a partir da exposição das células HL-60 a BPA e nitro-BPA nos indicam que as duas moléculas provocam alterações metabólicas distintas nesse tipo celular, independentes da via estrogênica, que levam a alterações predominantemente epigenéticas (BPA) ou genéticas e epigenéticas (nitro-BPA), que 
podem ter consequências fenotípicas, como progressão maligna, que precisam ser investigadas.

Foi observado que as células MCF-7 são mais resistentes que as células HL-60 à citotoxicidade induzida por BPA e nitro-BPA. Como resultado da exposição das células MCF-7 a BPA, houve pequeno aumento da permeabilidade da membrana plasmática $(250 \mu \mathrm{M})$, indução dos níveis de ROS após $24 \mathrm{~h}(25 \mu \mathrm{M})$ e aumento da população de células em sub G1, ou seja, com DNA fragmentado (100 $\mu \mathrm{M}$ e $250 \mu \mathrm{M})$, mas sem alteração do ciclo celular. No caso de nitro-BPA, foi observada parada do ciclo celular em G2/M (25 $\mu \mathrm{M}, 100 \mu \mathrm{M}$ e $250 \mu \mathrm{M})$, assim como aumento de permeabilidade da membrana plasmática após $24 \mathrm{~h}$ de incubação $(25 \mu \mathrm{M}, 250 \mu \mathrm{M})$, sem indução de ROS ou aumento de células em sub G1. Entretanto, observou-se aumento dos níveis de CEdG e 8-oxodG no DNA das células incubadas com BPA (100 $\mu \mathrm{M}, 250 \mu \mathrm{M})$ sem a ativação prévia de receptores Ah. A ativação dos receptores $A h$ com PCB levou a menor aumento do nível das lesões após as incubações com BPA. A maior resistência das células MCF-7 aos efeitos citotóxicos do BPA está provavelmente relacionada à ação estrogênica desse xenobiótico. A sinalização estrogênica juntamente com o aumento dos níveis de lesões no DNA aumenta a chance de mutações e de transformação maligna. Nas células com ativação do receptor Ah, BPA levou ainda ao aumento da hidroximetilação global, sem alteração da metilação global do DNA.

Os animais não diabéticos expostos ao BPA apresentaram quantidades diminuídas de promielócitos, blastos e bastonetes na medula óssea (aplasia medular), sem alteração no hemograma. Houve aumento dos níveis de CEdG no fígado, da metilação e hidroximetilação global do DNA hepático, e não foi observada alteração das marcas epigenéticas e adutos de DNA no rim ou na urina. Os animais diabéticos expostos ao BPA apresentaram aumento do número de eosinófilos e linfócitos na medula óssea, podendo-se sugerir a indução de um estado inflamatório alérgico, e aumento do número total de hemácias circulantes e do hematócrito. Houve aumento dos níveis de CEdG, da metilação e hidroximetilação global do DNA hepático, aumento dos níveis de 8-oxodG no DNA renal, sem alteração das marcas epigenéticas no rim, e não foi observada alteração dos adutos de DNA na urina.

Os dados obtidos apontam para a geração de ROS como uma importante via de cito- e genotoxicidade induzidas por BPA. Sua biotransformação para BPA-3,4quinona nos modelos utilizados parece ter menor importância para os efeitos, uma vez que não foi detectada a lesão BPA-Gua em nenhuma amostra de DNA, meio de cultura das células ou urina dos animais. Alterações metabólicas induzidas por BPA e ROS podem favorecer as alterações das marcas epigenéticas observadas no DNA das células HL-60, MCF-7 e fígado dos animais. Todas essas alterações podem contribuir para a transformação maligna de células expostas ao BPA.

Palavras-chaves: Bisfenol A, HL-60, MCF-7, Adutos de DNA, Diabetes. 


\begin{abstract}
RIBEIRO, A. L. T. Cytotoxic, Genotoxic and Epigenetics Effects of Bisphenol A on HL-60, MCF-7

cells and Rats 2015. 162f. Tese (Doutorado) - Faculdade de Ciências Farmacêuticas, Universidade de São Paulo, São Paulo, 2015.
\end{abstract}

Bisphenol A (BPA) is a compound widely used in polycarbonate plastic production and widespread in the environment, humans are chronic exposed to BPA in intrauterine period and entire life. The literature suggests the possibility of BPA increase the risk of developing cancers, but studies are required to enable the understanding of mechanisms by which this can occur.

$\mathrm{HL}-60$ cells were exposed to BPA or nitro-BPA at concentrations of 25 , 100 and $250 \mathrm{uM}(0.1 \% \mathrm{DMSO} \mathrm{v} / \mathrm{v})$ for 2,24 or 48 hours in presence or absence of $\mathrm{H}_{2} \mathrm{O}_{2}\left(40 \mathrm{nmol} / 5 \times 10^{4}\right.$ cells), MCF-7 cells followed a similar profile of exposure without the use of $\mathrm{H}_{2} \mathrm{O}_{2}$, but in presence or absence of Ah agonist receptor (PCB126). Male Sprague-Dawley rats received BPA daily over 4 weeks (50 $\mathrm{mg} / \mathrm{kg}$ body weight) by gavage in presence and absence of diabetes, with subsequent collection of urine, liver, kidney, bone marrow and circulating blood.

The viability, cell cycle, DNA fragmentation and the intracellular production of reactive oxygen species (ROS) was evaluated by flow cytometry, MPO activity and NO production was evaluated by fluorescence assay for HL60 cells, mitochondrial activity by XTT assay, and the global DNA methylation was checked by HPLC-PDA. DNA adducts 8-oxodG, CEdG, 1, $N^{6}-\varepsilon d A, 1, N^{6}-\varepsilon d G$ and BPA-Gua were quantified by HPLC- ESI-MS/MS in DNA of cells, culture medium, urine and tissue collected from Sprague-Dawley rats. Blood count and bone marrow examination were obtained in collaboration with Experimental Hematology Laboratory of University of Sao Paulo

We observed that both BPA and $\mathrm{BPANO}_{2}$ induced ROS generation in HL- 60 cells after 2 hours of incubation. BPA subsequently led to failure of mitochondrial respiratory chain activity, increased permeability of the plasma membrane, DNA fragmentation, arrest in G2/M phase of cell cycle, DNA hypermethylation with global hipohydroxymethylation.

We saw low cytotoxicity in HL-60 cells induced by nitro-bpa $\mathrm{n}$ the same concentration, without loss of mitochondrial respiratory chain activity, discrete DNA fragmentation, but leading cell cycle to stopping at G0/G1 phase, and induction of DNA global hypermethylation. No lesions were observed in the DNA of HL-60 cells. The results obtained from the exposure of HL-60 cells to BPA and nitro-BPA indicate that these two molecules induce different metabolic abnormalities in this cell line, independent of estrogen pathway, leading to changes in epigenetic (BPA) or genetic and epigenetic (nitro-BPA) profile, that can induce phenotypic consequences such as malignant progression.

It was observed along the study that MCF-7 cells are more resistant than HL-60 cells to cell damage induced by BPA and nitro-BPA. As a result of MCF-7 cells exposure to BPA, we saw a slight increase in membrane permeability $(250 \mathrm{mM})$, ROS generation after $24 \mathrm{~h}(25 \mathrm{mM})$ and increase in cell population in sub G1, so we had DNA fragmentation (100 uM and $250 \mathrm{uM}$ ), but with no effect on cell cycle. However, we observed increased levels of CEdG 
and 8-oxodG on DNA of cells incubated with BPA (100 uM, $250 \mathrm{mM}$ ) without prior activation of Ah receptors. The activation of Ah receptors with PCB took a small increase in the level of DNA lesions after incubations with BPA. MCF-7 cells resistance to the cytotoxic effects of BPA is probably related to estrogen action of this compound. Estrogen signaling in addition with the increased levels of DNA damage increases the chance of mutations and malignant transformation. In cells with Ah receptor activation, BPA also led to increased DNA global hydroxymethylation, without changing the global DNA methylation.

Nondiabetic animals exposed to BPA had decreased amounts of promyelocytes, blasts and rods in the bone marrow, with any change in blood count. There were an increase of CEdG levels in liver, methylation and global hydroxymethylation on hepatic DNA, and was observed any alteration on epigenetic markers and DNA adducts in kidney or urine. On the other hand diabetic animals exposed to BPA showed increased numbers of eosinophils and lymphocytes in bone marrow, suggesting the induction of an allergic inflammatory state. There were increased levels of CEdG, methylation and global hydroxymethylation on hepatic DNA, increased 8-oxodG levels on kidney DNA without changing epigenetic markers, was not observed DNA adducts in urine. The data obtained indicate that the generation of ROS could be the major route of cytotoxic and genotoxic induced by BPA exposure.

BPA biotransformation to BPA-3,4-quinone used in the models seem to have poor effects, since we was not detected BPA-Gua lesion in any DNA sample, culture medium of cells or urine of the animals. Metabolic changes induced by BPA and ROS can enable changes in epigenetic markers observed in the DNA of HL-60 cells, MCF-7 and liver tissue. All these changes may contribute to malignant transformation of cells that were exposed to BPA.

Keywords: Biphenol A, HI-60, MCF-7, DNA Adducts, Diabetes 
Intradusãa 


\section{Introdução}

\subsection{Bisfenol A}

O Bisfenol A (BPA), 2,2'-bis[4-hidroxifenil]propano (Figura 1), foi sintetizado pela primeira vez em 1891, tornando-se em 1957 um insumo largamente utilizado no ramo industrial. O BPA é uma das principais substâncias utilizadas na síntese do plástico policarbonato, conferindo-lhe resistência térmica e mecânica, além de proporcionar transparência ao plástico. O policarbonato é utilizado para produzir uma variedade de produtos de uso comum, incluindo mamadeiras infantis, garrafas de água, potes para acondicionamento de alimentos, equipamentos esportivos, dispositivos médicos e dentários, cimentos e selantes dentais, lentes de óculos, CDs, DVDs e eletrodomésticos (Herath, Jin et al. 2004; Alonso-Magdalena, Vieira et al. 2010; Galloway, Cipelli et al. 2010; American Dental Association Council on Scientific 2014). Outras aplicações do BPA no ramo industrial são atribuídas à produção de PVC, fabricação de papel termo sensível, poliuretano, poliamida e retardantes/inibidores de chama, sendo utilizados para este ramo de aplicação cerca de $10 \%$ da produção anual de BPA (EURAR, 2003; E/E, 2003; EFSA, 2006(Zhang, Xu et al. 2014).

Além da presença nos produtos plásticos, o BPA é utilizado para a produção da resina epóxi, largamente utilizada na produção de tintas, adesivos, revestimentos de latas de alumínio comumente utilizadas para acondicionar bebidas e alimentos. A literatura ainda aponta a utilização desta resina na construção civil, como selante para estruturas de mármore e granito, utilizadas principalmente nos estágios de acabamento de construções (2008; Groff 2010; 
Schecter, Malik et al. 2010; Manfo, Jubendradass et al. 2014; Zhang, Xu et al. 2014).

Por fazer parte de tantos processos industriais a literatura aponta que a produção anual de BPA chega a 2,2 milhões de toneladas, o que ainda não é suficiente para suprir a demanda de mercado, contudo o dado mais alarmante é que cerca de $25 \%$ deste montante é liberado no meio ambiente (Ranciere, Lyons et al. 2015)

A estrutura do BPA é semelhante à do carcinógeno dietilestilbestrol (DES) (Figura 1), um estrógeno sintético não-esteroidal utilizado durante muitos anos para o tratamento de problemas relacionados a próstata e ainda para diminuir o risco de aborto espontâneo (Fenichel, Chevalier et al. 2013). Alguns anos depois do seu uso o DES foi considerado um agente cancerígeno por aumentar o risco de câncer de mama e vagina, além do risco de câncer de testículo em homens, quando a exposição ocorre durante o desenvolvimento fetal (Keri, Ho et al. 2007; Reed and Fenton 2013; Bhan, Hussain et al. 2014; Nomura, Matoda et al. 2015). A semelhança do BPA com esse hormônio sintético fez surgir dúvidas quanto à sua segurança, o que levou ao estudo da possível atividade estrogênica do BPA, que em pouco tempo gerou resultados suficientes para considerá-lo um composto xenoestrogênico (Masuda, Terashima et al. 2005; Cavalieri and Rogan 2010; Renz, Volz et al. 2013; Thigpen, Setchell et al. 2013; Bhan, Hussain et al. 2014). 


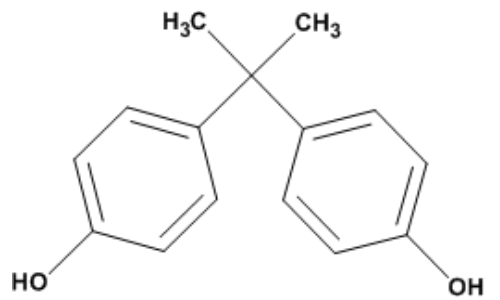

(BPA)

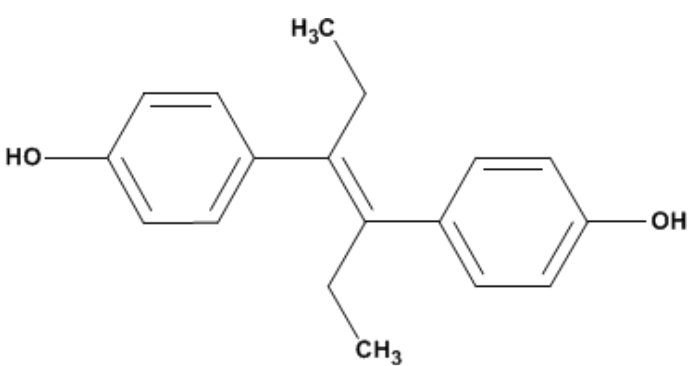

(DES)

Figura 1 - Estruturas químicas do Bisfenol A (BPA) e do dietilestilbestrol (DES)

No Brasil a importação, fabricação e venda de mamadeiras contendo BPA foram proibidas pela ANVISA a partir de Janeiro de 2012, decisão alinhada às medidas já adotadas em outros países, como Canadá e Estados da União Europeia, para reduzir a exposição de crianças a esse xenoestrógeno. Essa proibição foi realizada pela RDC 41/2011.

\subsection{Exposição ao BPA}

A grande utilização unida às suas características físico-químicas faz do BPA um composto largamente distribuído no meio ambiente e disponível para exposição do ser humano no meio ocupacional, ambiental e pelo consumo de alimentos (Geens, Aerts et al. 2012; Park, Koduru et al. 2014).

Ocupacionalmente os humanos estão expostos ao BPA em fábricas de tintas, em centros de funilaria automotiva ou em indústrias produtoras de adesivos, além de trabalhadores que utilizam uniformes com revestimento antichama e, sobretudo, nas indústrias de síntese e manipulação do BPA ou da resina epóxi (Jolanki, Kanerva et al. 1995; Vandenberg, Hauser et al. 2007; Wetherill, Akingbemi et al. 2007; Groff 2010). 
Evidências literárias citam a exposição humana ao BPA em concentrações variadas no meio ambiente, partindo principalmente de fontes como água ou poeira contaminada pelo uso rotineiro do BPA, além da atividade de reciclagem por incineração do plástico ou papel termo sensível que permite a liberação do BPA no ar (Staples, Dorn et al. 1998; West, Goodwin et al. 2001; Goodwin, Mynar et al. 2005; Kang, Katayama et al. 2006).

A exposição por via oral não inclui somente alimentos que de alguma forma entraram em contato com o BPA durante o cultivo ou preparação, mas também pela contaminação originada pelo processo de lixiviação (transferência) do BPA dos acondicionantes de alimentos. A literatura mostra que o BPA pode lixiviar do acondicionante plástico (potes, garrafas, copos) para o acondicionado (água ou produtos alimentícios), ou ainda pelo uso da resina epóxi como revestimento interno de latas metálicas que acondicionam alimentos e bebidas (Fasano, Esposito et al. 2015). A partir do revestimento das latas de alimentos, foi detectada liberação de BPA em concentrações que variaram de 0,004 a $0,023 \mathrm{mg} / \mathrm{Kg}$ de alimento (Ehlert, Beumer et al. 2008; Fasano, Esposito et al. 2015). O processo de lixiviação pode acontecer pela polimerização incompleta, ou ainda por hidrólise favorecida por temperatura, facilitando a liberação do BPA para o meio. Esse processo pode ser aumentado quando o acondicionado apresenta em sua composição compostos químicos como cafeína, taurina ou glicose em concentrações elevadas, o que favorece a hidrólise das ligações de BPA mal polimerizado (Ehlert, Beumer et al. 2008; Mendiola, Jorgensen et al. 2010; Rogers, Metz et al. 2013; Thigpen, Setchell et al. 2013). 
Dentre as vias de exposição do ser humano ao BPA, a via oral é a mais preocupante, pois essa exposição atinge uma gama de indivíduos com faixa etária variada e diferentes atividades laborais. As agências regulamentadoras Environmental Protection Agency (EPA) americana e a European Food Safety Authority (EFSA) preconizaram que em humanos a quantidade de ingestão diária tolerável (TDI) para o BPA é de 50 e $25 \mu \mathrm{g} / \mathrm{Kg} /$ dia, respectivamente. Esse limite foi calculado pela redução da dose em 1000 vezes a partir de estudos realizados pelo National Toxicology Program (NTP) na década de 1980, em que a ação carcinogênica foi avaliada em ratos e camundongos alimentados cronicamente com BPA, apresentando resultados que apontavam a Menor Dose com Efeito Adverso Observável (LOAEL) de $50 \mathrm{mg} / \mathrm{Kg} / \mathrm{dia}$. A administração de BPA foi iniciada na quinta semana de vida e ocorreu por 103 semanas, não tendo sido evidenciada uma ação carcinogênica, apesar de ter sido verificado leve aumento da incidência de câncer testicular e do sistema hematopoiético (NTP, 1982). Entretanto, limitações do estudo do NTP, tais como exposição dos animais somente na fase adulta, uso de altas concentrações de BPA sem considerar que interferentes endócrinos em baixas concentrações podem provocar efeitos não evidenciados nas concentrações mais altas, uso de apenas uma linhagem de ratos e camundongos com susceptibilidades desconhecidas ao desenvolvimento de câncer por exposição ao BPA, e falta de avaliação da susceptibilidade para desenvolvimento de câncer quando da exposição concomitante a outros carcinógenos, não permitem concluir que o BPA não seja carcinogênico (Keri, Ho et al. 2007). Com base no conhecimento atual dos modos de ação do BPA, o limite recomendado pela EPA pode não ser seguro. 
Um humano pode ingerir de 1,7 a 2,7 $\mu \mathrm{g}$ de BPA por dia, procedente de alimentos contaminados por acondicionamento ou cultivo, sem considerar o BPA presente na poeira que o indivíduo pode deglutir juntamente com os alimentos, em níveis que variam de 0,008 a 0,014 $\mu \mathrm{g}$ por dia. A esses valores podem ser somadas as concentrações de BPA em refrigerantes enlatados e em água engarrafada, variando de 0,0045 a 4,5 $\mu$ g por litro e 0,1 a 0,7 $\mu \mathrm{g}$ por litro, respectivamente (Dekant and Volkel 2008; Ehlert, Beumer et al. 2008; Cao, Corriveau et al. 2009; Groff 2010; Loganathan and Kannan 2011). A estimativa da União Européia é de que os seres humanos estejam expostos a BPA no intervalo de 10 a $600 \mu \mathrm{g} / \mathrm{dia}$ ou 0,7 a $9 \mu \mathrm{g} \mathrm{BPA} / \mathrm{Kg} / \mathrm{dia}$, considerando todas as fontes (Naik and Vijayalaxmi 2009).

\subsection{Ação estrogênica do BPA}

A ação do BPA sobre o sistema endócrino é conhecida, com vários estudos comprovando a influência do BPA sobre a função hormonal de roedores, o que o levou a ser classificado como um interferente endócrino (Rogers, Metz et al. 2013; Bittner, Denison et al. 2015; Patterson, Mo et al. 2015; Vrooman, Oatley et al. 2015).

Os interferentes endócrinos podem se ligar a receptores hormonais e desempenhar atividade agonista ou antagonista. Podem bloquear a ligação de outros hormônios que naturalmente se ligariam ao receptor em questão ou ainda aumentar a concentração hormonal, levando a uma alteração na ação desses hormônios (Schug, Janesick et al. 2011; Geens, Aerts et al. 2012).

O BPA pode se ligar aos receptores $\beta$ estrogênicos e atuar como agonista, e aos receptores a estrogênicos e atuar como agonista ou 
antagonista, desencadeando efeitos que dependem da concentração e tempo. Tal característica faz com que o BPA apresente efeitos tanto em concentrações baixas quanto altas, havendo uma resposta não-monotônica a doses. Esse fenômeno conhecido como hormese faz com que haja discrepância entre dados de diferentes estudos envolvendo o BPA e dificulta o estabelecimento de uma concentração limite para exposição humana (Hiroi, Tsutsumi et al. 1999; Schug, Janesick et al. 2011; Rogers, Metz et al. 2013; Thigpen, Setchell et al. 2013).

Em diversos estudos, fetos de roedores expostos a baixas doses de BPA (20 - $400 \mu \mathrm{g} / \mathrm{Kg} / \mathrm{dia})$ apresentaram efeitos estrogênicos após o nascimento (Calafat, Kuklenyik et al. 2005). Os efeitos são diversos, como antecipação da puberdade, hiperplasia de próstata, diminuição do número de espermatozoides, diminuição dos níveis de testosterona, alteração do desenvolvimento e organização tecidual da glândula mamária, e diminuição da resposta celular induzida por hormônios, além de carcinoma mamário, diabetes, doenças cardiovasculares, alterações das funções de enzimas hepáticas, efeitos sobre o desenvolvimento cognitivo e a reprodução (Zoeller, Bansal et al. 2005; Galloway, Cipelli et al. 2010; Groff 2010; Melzer, Rice et al. 2010; Loganathan and Kannan 2011). Camundongos expostos oralmente ao BPA (20 - $100 \mu \mathrm{g} / \mathrm{kg} / \mathrm{dia})$ apresentaram alteração na meiose, com ocorrência de gametas aneuplóides, alteração que é conhecida como a principal causa de retardo mental e também responsável pela interrupção da gravidez em humanos (Hassold and Hunt 2001; Hunt, Koehler et al. 2003; Popovic, Martinez-Garcia et al. 2014). 
É possível que produtos resultantes da biotransformação de BPA por citocromo P450, mais especificamente as isoformas CYP 1A1 e 1A2, possuam maior afinidade pelos receptores de estrógeno que a molécula original, explicando o fato de a ação estrogênica observada in vivo ser muito maior que nos estudos in vitro (Ben-Jonathan and Steinmetz 1998). Essa hipótese foi investigada por Yoshihara e colaboradores, tendo sido constatado que a biotransformação de BPA por fração S9 de fígado humano e de ratos Wistar resulta em pelo menos um metabólito com atividade estrogênica muitas vezes aumentada em relação ao BPA, em modelos in vitro. A atividade estrogênica foi parcialmente inibida ao ser utilizado um inibidor de P450 (Yoshihara, Makishima et al. 2001).

Ainda que a literatura apresente muitos efeitos do BPA sobre o sistema endócrino, conhece-se muito pouco a respeito da toxicidade deste xenoestrógeno sobre os demais sistemas do organismo. A falta de concordância entre diferentes estudos ainda deixa uma lacuna no conhecimento sobre sua toxicidade e levanta questões sobre sua biotransformação e geração de intermediários reativos, que poderiam ajudar a esclarecer vias pelas quais BPA exerce seus efeitos tóxicos.

\subsection{Biotransformação do BPA}

O BPA pode ser biotransformado por humanos e roedores ao nível intestinal e hepático, durante o metabolismo de primeira passagem, formando vários metabólitos. Alguns trabalhos mostram que roedores tem capacidade de metabolizar o BPA, administrado por via oral, transformando-o em um metabólito conjugado com o acido glicurônico (GLcA), formando um complexo 
GLCA-BPA, sendo o metabólito encontrado em maior quantidade na urina desses animais. Contudo, outro metabólito, em menor quantidade, foi encontrado nessa mesma matriz, sendo um produto da conjugação do BPA com sulfato, formando um complexo S-BPA (Yoshihara, Mizutare et al. 2004).

Além do GLcA-BPA e do S-BPA, a literatura mostra a formação de metabólitos gerados via citocromo P450, onde o BPA sofre reações oxidativas formando produtos altamente reativos (Yoshihara, Makishima et al. 2001; Jaeg, Perdu et al. 2004). Vários metabólitos são formados por esta via, por exemplo, metabólitos hidroxilados do BPA, como o 3-OH-BPA, metabólito este que pode ser oxidado formando um composto altamente reativo, denominado de BPA3,4-quinona. Este metabólito tem sido relacionado com atividade genotóxica, como formação do aduto de DNA BPAQ- $N^{7}$ Gua e formação de sítios apurínicos (Bindhumol, Chitra et al. 2003; Edmonds, Nomachi et al. 2004).

A compreensão das vias de biotransformação do BPA em mamíferos é um passo necessário para que se possam estimar riscos à saúde decorrentes da exposição frequente a esse xenobiótico. Estudos in vivo vêm sendo desenvolvidos com esse intuito, principalmente considerando a exposição a baixas doses, sendo possível verificar que apesar de o conjugado BPAglicuronídeo ser o principal metabólito excretado, vários outros metabólitos, incluindo conjugados de glicose, glicuronídeos desidratados, duplos conjugados, compostos metoxilados conjugados e dissacarídeos são detectados em tecidos e fetos de camundongos fêmeas expostos a BPA (25 $\mu \mathrm{g} / \mathrm{Kg}$, s.c.) (Zalko, Soto et al. 2003). A partir da caracterização de vários metabólitos formados in vivo é possível inferir que intermediários reativos sejam gerados, os quais podem contribuir para a toxicidade. De fato, uma 
fração de BPA não passível de extração foi detectada após $24 \mathrm{~h}$ em fetos das fêmeas que receberam BPA. Tal fração pode ser decorrente da ligação de intermediários reativos a biomoléculas, dentre eles metabólitos hidroxilados, como BPA-catecol (Zalko, Soto et al. 2003). É possível que tecidos capazes de reter xenoestrógenos durante a organogênese estejam mais sujeitos a instabilidade genética, mutações e aberrações celulares que podem permanecer latentes e se manifestar na fase adulta (Ben-Jonathan and Steinmetz 1998).

Em um estudo de farmacocinética em humanos, seis voluntários adultos que receberam $\mathrm{D}_{16}$-BPA (5 mg) oralmente apresentaram rápida absorção no trato gastrointestinal, com quase completa recuperação da dose administrada na forma conjugada $D_{16}$-BPA glicuronídeo na urina após $24 \mathrm{~h}$ (meia-vida de excreção urinária de 5,4 h) (Volkel, Colnot et al. 2002). Outros estudos, no entanto, mostram que a forma não conjugada do BPA é frequentemente detectada em humanos e que sua eliminação não é tão rápida, sugerindo meiavida mais longa, bioacumulação ou exposições não orais mais significativas (Stahlhut, Welshons et al. 2009; Vandenberg, Colborn et al. 2012). Concentrações reportadas de BPA na urina de humanos em condições normais de exposição estão na faixa de 0,2 a $20 \mu \mathrm{g} / \mathrm{L}$, havendo diferenças geográficas e temporais (Calafat, Kuklenyik et al. 2005; Lang, Galloway et al. 2008). As maiores concentrações urinárias de BPA foram associadas à ocorrência de doença cardiovascular, diabetes e concentrações anormais das enzimas hepáticas $\gamma$-glutamiltransferase, lactato desidrogenase e fosfatase alcalina em um estudo transversal que envolveu 1455 participantes entre 18 e 74 anos de idade nos Estados Unidos (Lang, Galloway et al. 2008). Níveis circulantes de 
BPA não conjugado reportados em soro humano estão na faixa de 0,2 a 20 $\mu \mathrm{g} / \mathrm{L}$ (Welshons, Nagel et al. 2006). Não há relatos na literatura sobre níveis de BPA em soro e urina da população brasileira.

\subsection{Genotoxicidade do BPA}

BPA, ao ser metabolizado via citocromo P450, gera quinonas, moléculas reativas capazes de se ligarem covalentemente ao DNA, RNA e proteínas. Além disso, quinonas podem ser reduzidas a catecóis e entrar em um ciclo redox, via semi-quinonas, favorecendo a geração de espécies reativas de oxigênio (ROS) (Figura 2). O esteroide sintético DES, que apresenta estrutura semelhante ao BPA (Figura 1), sofre esse tipo de biotransformação, sendo detectada a formação de adutos de DNA in vivo (Liehr 1990; Ben-Jonathan and Steinmetz 1998). Da mesma forma, BPA é biotransformado para o-quinona, gerando adutos de DNA in vitro e in vivo que foram detectados por ${ }^{32} \mathrm{P}$ postlabeling (Atkinson and Roy 1995; Atkinson and Roy 1995; Izzotti, Kanitz et al. 2009; De Flora, Micale et al. 2011). Pelo menos 7 adutos foram gerados na reação de DNA e dGMP (desoxiguanosina monofosfato) com BPA-3,4-quinona e com BPA ativado enzimaticamente por fração microssomal ou peroxidase $/ \mathrm{H}_{2} \mathrm{O}_{2}$. Linhagens de células de próstata humana apresentaram níveis aumentados de adutos de DNA quando expostas a altas concentrações

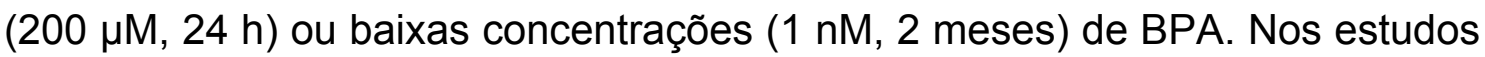
in vivo foi detectada a formação de adutos de DNA no fígado e células mamárias de ratos e camundongos. Entretanto, em nenhum desses estudos as estruturas dos adutos foram elucidadas (Atkinson and Roy 1995; Izzotti, Kanitz et al. 2009; De Flora, Micale et al. 2011). 
Nos dois estudos realizados até o momento para caracterização estrutural dos adutos de DNA gerados por BPA, foi verificado que o metabólito BPA-3,4-quinona origina os adutos 3-OH-BPA- $N^{7}$ dGuo, 3-OH-BPA- $N^{7}$ dAdo e 3OH-BPA- $N^{3}$ dAdo e os respectivos produtos de depurinação ao reagir com os nucleosídeos/nucleotídeos isoladamente ou com DNA in vitro (Figura 3) (Edmonds, Nomachi et al. 2004; Quu, Yang et al. 2004). A reação ocorre preferencialmente com a base guanina, sendo que o aduto de adenina não foi observado nas reações com DNA (QIU et al., 2004). Sítios apurínicos no DNA são reconhecidamente mutagênicos e a indução dessas lesões por BPA pode fazer parte do seu mecanismo de carcinogênese (QIU et al., 2004). Estrógenos sofrem o mesmo processo de biotransformação mencionado acima, gerando adutos de DNA que também depurinam. Tais adutos são apontados como potenciais biomarcadores para predizer o risco de câncer de próstata (Yang, Hong et al. 2009).

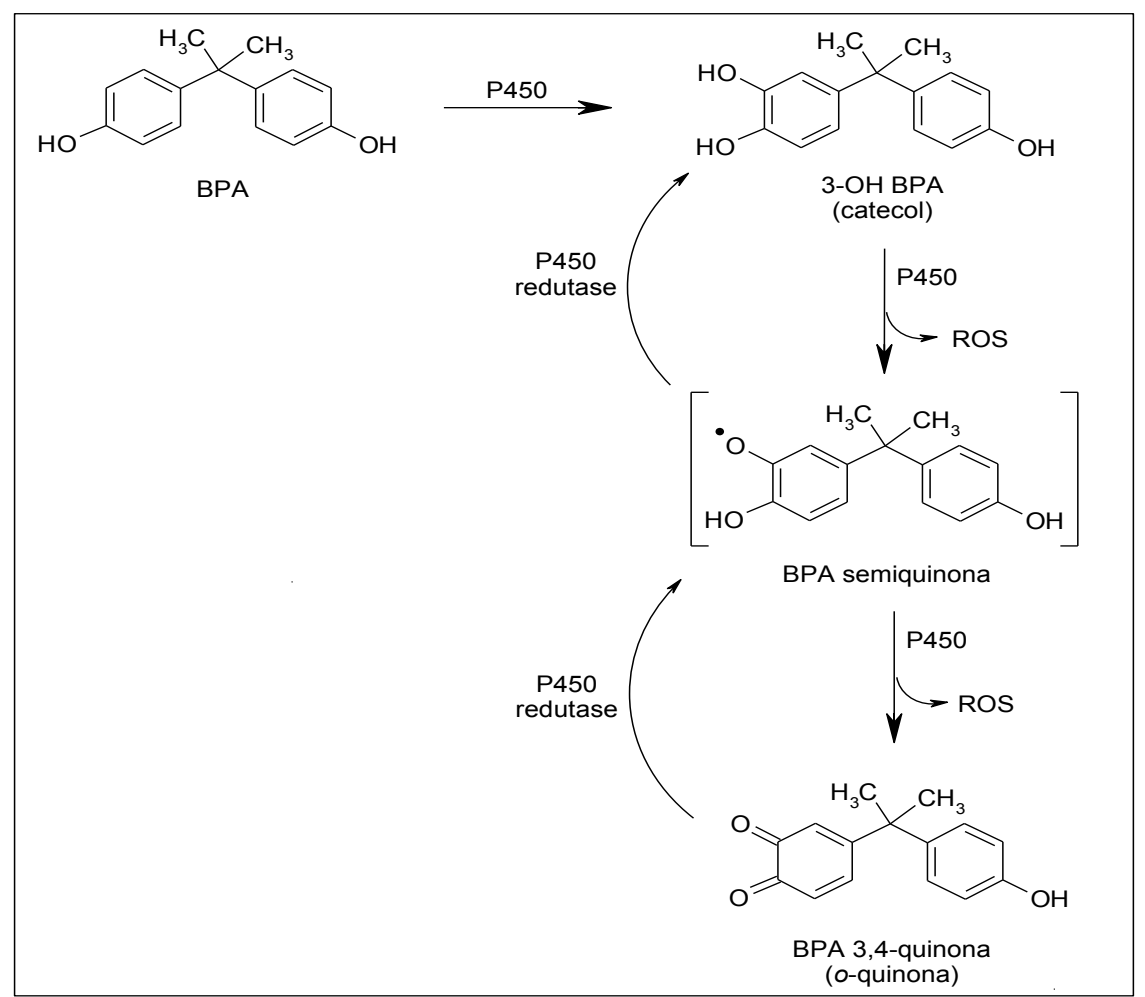

Figura 2 - Ciclo redox envolvendo quinona, semi-quinona e catecol do BPA 

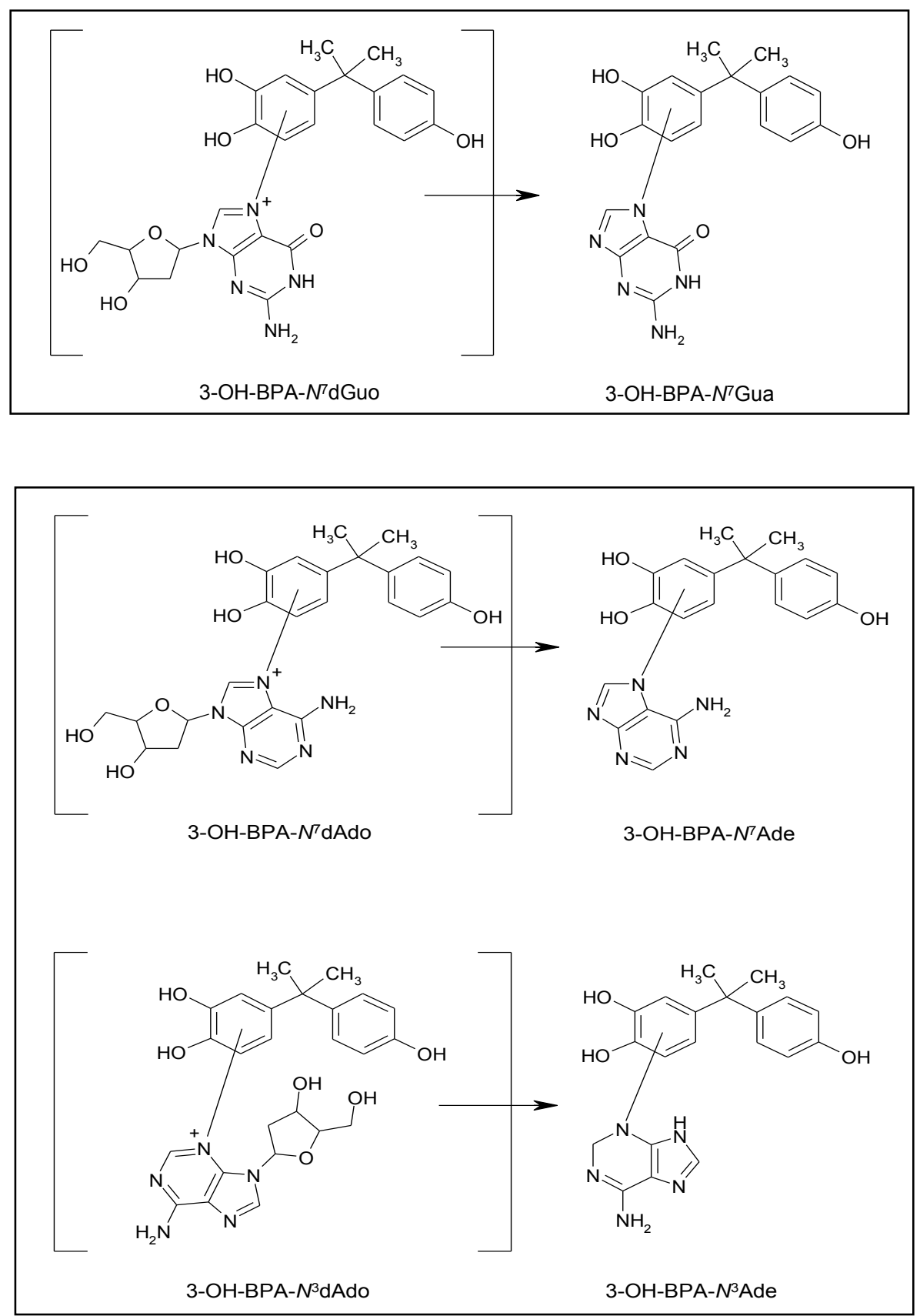

Figura 3 - Adutos resultantes da reação de BPA-3,4-quinona com dGuo e dAdo.

Ao ser avaliada a genotoxicidade do BPA em células da medula óssea de camundongos Swiss, in vivo, não foi observada a indução de efeitos clastogênicos, mas sim de lesões/intervalos acromáticos ao nível cromossômico que podem afetar a condensação dos cromossomos e o aparato 
mitótico. Tais lesões representam grande amplificação de danos moleculares iniciais no DNA. O mecanismo molecular subjacente a essas lesões induzidas por BPA é desconhecido, mas a formação de adutos de DNA é apontada como possível explicação para essas observações. Além disso, foram observados efeitos c-mitóticos, que representam uma forma indireta de testar o potencial aneugênico devido a danos nas fibras do fuso (Naik and Vijayalaxmi 2009). É conhecido há algum tempo que tanto BPA quanto outros xenoestrógenos interferem na organização de microtúbulos, o que pode levar a aneuploidia e aberrações cromossômicas (Liehr 1990). Uma vez que os efeitos mencionados acima nas células da medula óssea dos camundongos foram observados no período de 48 a 72 h após a administração de BPA (50 e 100 mg/kg, em doses orais únicas), existe a possibilidade de que produtos da biotransformação de BPA e/ou ROS geradas no processo estejam envolvidos (Naik and Vijayalaxmi 2009).

A administração oral de baixas doses de BPA $(0,2-20 \mu \mathrm{g} / \mathrm{Kg} / \mathrm{dia})$ a ratos Wistar por 30 dias resultou em estresse oxidativo hepático em todas as doses testadas, com redução das atividades das enzimas antioxidantes superóxido dismutase, catalase, glutationa redutase e glutationa peroxidase e aumento dos níveis de $\mathrm{H}_{2} \mathrm{O}_{2}$ e peroxidação lipídica de forma dose dependente. Essas alterações não ocorreram com a administração concomitante de vitamina C, confirmando o efeito oxidante do BPA (BINDHUMOL et al., 2003). Ao ser feita a administração de doses mais elevadas de BPA $(25 \mathrm{mg} / \mathrm{Kg} / \mathrm{dia}, 3$ dias por semana) em ratos por 50 dias, efeitos oxidantes mais drásticos foram observados no fígado dos animais, os quais foram agravados pela administração concomitante de vitamina C (Korkmaz, Ahbab et al. 2010). Foi 
ainda observada, em outros estudos, a indução de estresse oxidativo por BPA em cérebro, rim, testículos e esperma de camundongos e ratos (Chitra, Latchoumycandane et al. 2002; Chitra, Rao et al. 2003; Kabuto, Hasuike et al. 2003; Kabuto, Amakawa et al. 2004; De Flora, Micale et al. 2011). Estresse oxidativo é apontado como o principal mecanismo de indução de danos em DNA na linhagem germinativa. Tais danos são correlacionados a prejuízo na fertilização, baixas taxas de implantação embrionária, aumento da incidência de abortos, alta taxa de morbidade na descendência e diminuição da fertilidade. Substâncias estrogênicas que possuem o grupo catecol em suas estruturas mostraram-se indutoras de estresse oxidativo e de danos em DNA de espermatozóides humanos in vitro (Bennetts, De luliis et al. 2008).

Como mencionado anteriormente, foi verificado que BPA induz danos à medula óssea e possivelmente o câncer no sistema hematopoiético de roedores (Naik and Vijayalaxmi 2009). No estudo realizado por Korkmaz e colaboradores foi verificado que, além do dano hepático, BPA induziu anemia macrocítica hipercrômica nos ratos quando administrado em conjunto com vitamina $\mathrm{C}$, podendo representar uma interferência na eritropoiese ou aumento da destruição de eritrócitos (Korkmaz, Ahbab et al. 2010). O mesmo efeito foi observado por Ulutas e colaboradores, acompanhado por indução de fragmentação do DNA em células do sangue (Ulutas, Yildiz et al. 2011).

A literatura traz poucos dados sobre biotransformação do BPA por mieloperoxidase (MPO), apesar de a peroxidase de rábano (HRP) ser utilizada experimentalmente para a remoção de BPA de água através da catálise de formação de polímeros insolúveis de BPA via oxidação (Davis and Burns 1990). MPO, no entanto, oxida fenóis, além de ser uma enzima de grande 
importância para a metabolização de diversos xenobióticos no organismo humano (Xu, Chi et al. 2013).

MPO utiliza $\mathrm{H}_{2} \mathrm{O}_{2}$ para catalisar a biotransformação de uma série de compostos orgânicos. A princípio, MPO se encontra em uma forma inativa, a forma férrica $\left(\mathrm{Fe}^{+3}\right)$, que reage com $\mathrm{H}_{2} \mathrm{O}_{2}$ e gera o composto I $\left(\mathrm{MPO}+\mathrm{H}_{2} \mathrm{O}_{2} \rightarrow\right.$ composto I $+\mathrm{H}_{2} \mathrm{O}$ ), que é a forma cataliticamente ativa da MPO (Furtmuller, Zederbauer et al. 2006; Hansson, Olsson et al. 2006). Por sua vez, o composto I oxida o ânion cloreto para $\mathrm{HClO}$ (composto I $+\mathrm{Cl}^{-}+\mathrm{H}^{+} \rightarrow \mathrm{MPO}+\mathrm{HClO}$ ) (Hampton, Kettle et al. 1998).

Com a formação do composto I, inicia-se um ciclo peroxidásico clássico envolvendo o composto I, composto II e a forma férrica. Nesse ciclo, os compostos I e II oxidam substratos orgânicos $(\mathrm{RH})$. A produção de $\mathrm{HClO}$ pode ser diminuída caso moléculas de $\mathrm{RH}$ ou ânion superóxido estejam presentes no meio para reagir com o composto II e converter a MPO para a forma férrica, iniciando um novo ciclo (composto $\mathrm{II}+\mathrm{RH} / \mathrm{O}_{2}{ }^{\bullet} \rightarrow \mathrm{MPO}+$ radical $\left(\mathrm{R}^{*}\right)+\mathrm{H}^{+}$). Existe também a possibilidade de formação do composto III a partir da reação da MPO na forma férrica com excesso do ânion superóxido ou $\mathrm{H}_{2} \mathrm{O}_{2}(\mathrm{MPO}+$ $\mathrm{H}_{2} \mathrm{O}_{2} / \mathrm{O}_{2}{ }^{\bullet} \rightarrow$ composto III $+\mathrm{H}^{+}$) (Hampton, Kettle et al. 1998). A figura abaixo ilustra as reações de MPO no ciclo peroxidásico clássico. 


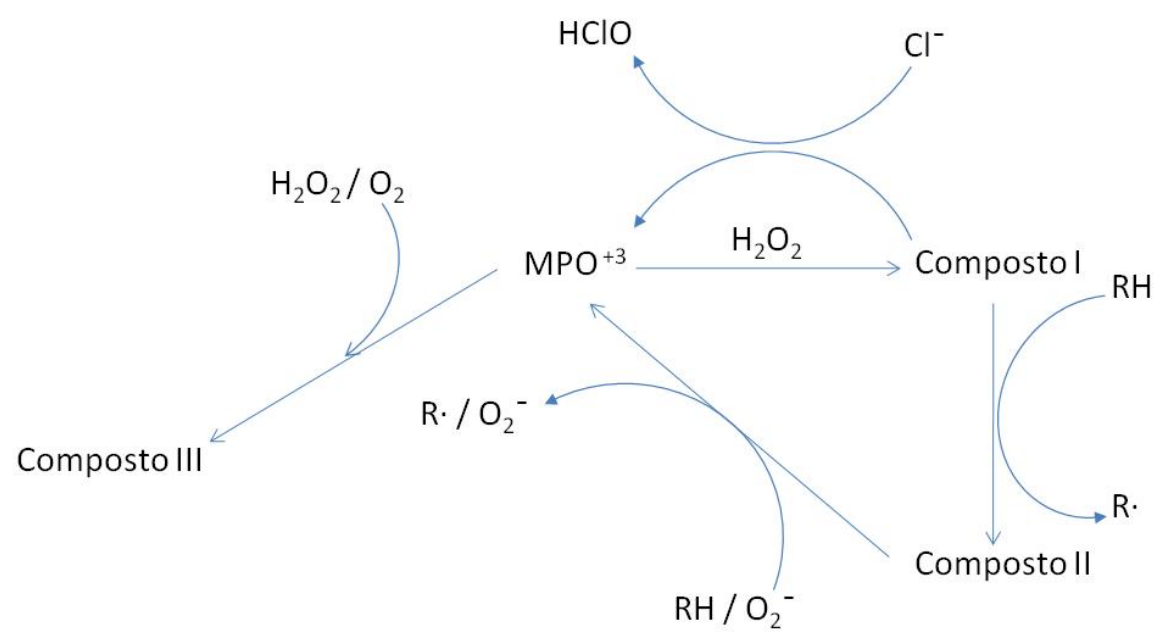

Figura 4 - Ciclo peroxidásico da MPO. Adaptado de HAMPTON et al., 1998

Dados da literatura mostram ainda que BPA pode ser nitrado ao reagir com nitrito, formando os produtos 3-nitro-BPA ou 3,3'-dinitro-BPA altamente mutagênicos. Não há informações quanto à reatividade dessas moléculas com DNA ou sobre a geração de ROS pelas mesmas. Uma vez que nitrito está presente em alimentos e a nitração de moléculas pode ocorrer no trato digestivo e em condições inflamatórias, é importante investigar a possibilidade de BPA nitrado levar a danos em biomoléculas, visto que a literatura o destaca como uma molécula mutagênica (Schrader, Langlois et al. 2002; Masuda, Terashima et al. 2005).

Atualmente são considerados quatro modos de ação do BPA que podem contribuir conjuntamente para o aumento do risco de câncer: interferência endócrina estrogênica, indução de progressão tumoral, genotoxicidade, e reprogramação do desenvolvimento com aumento da susceptibilidade a outros eventos carcinogênicos (Keri, Ho et al. 2007). Apesar de muitos estudos in vitro e in vivo evidenciarem esses modos de ação, são necessários atualmente estudos que possibilitem o entendimento de mecanismos pelos quais os 
diversos efeitos são gerados. Além disso, a realização de estudos epidemiológicos moleculares para avaliar a relação causal entre exposição a BPA e efeitos adversos em humanos depende de avanços na pesquisa de novos marcadores e do desenvolvimento de métodos sensíveis para sua detecção/quantificação (Keri, Ho et al. 2007). 
Objetivos 


\section{Objetivos}

Avaliar efeitos citotóxicos, genotóxicos e epigenéticos do BPA e $\mathrm{BPANO}_{2}$ em modelos in vitro, utilizando duas linhagens celulares com características distintas: células HL-60 derivadas de leucemia promielocítica humana e células MCF-7 derivadas de adenocarcinoma mamário humano, buscando entender mecanismos pelos quais os efeitos são gerados.

Avaliar efeitos citotóxicos, genotóxicos e epigenéticos do BPA in vivo em ratos Sprague Dawley sadios ou na vigência de diabetes.

\section{Objetivos específicos:}

1- Avaliar efeitos citotóxicos, genotóxicos e epigenéticos do BPA em dois modelos celulares distintos: células HL-60 com ou sem ativação de MPO; e células MCF-7 com ou sem ativação de CYP450.

2- Avaliar, comparativamente, efeitos citotóxicos, genotóxicos e epigenéticos do $\mathrm{BPANO}_{2}$ nas células HL-60 e MCF-7.

3- Avaliar efeitos tóxicos do BPA in vivo, avaliando o hemograma, mielograma e efeitos genotóxicos e epigenéticos no fígado e rim dos animais. 
Matexial e Metodos 


\section{Material e Métodos}

\subsection{Equipamentos Utilizados}

\subsubsection{Citômetro de Fluxo}

Todos os ensaios relacionados com citometria de fluxo foram realizados em um citômetro de fluxo FACS Canto II (Becton Dickinson, Mountains View, CA, USA) disponibilizado pelo Prof. Sandro R. Almeida (FCF-USP) e analisados usando o software Flow Jo ${ }^{\circledR}$ (versão 9.1). Os dados de 10.000 células foram obtidos e somente as células morfologicamente viáveis foram consideradas para análise.

\subsubsection{Espectrofotômetro}

Todos os ensaios que utilizaram leitura de absorbância foram realizados no leitor de microplacas com ajuste de comprimento de onda 190 a 880nm SpectraMAx 190® (Molecular Devices - Chicago, IL, USA) e os dados gerados foram analisados pelo software SoftMax Pro versão 5.4.

Para leitura de fluorescência foi utilizado o leitor de microplacas multicanal Synergy $H 1^{\circledR}$ (Biotek - Winooski, VM, USA ). Os dados foram analisados pelo software Gen 5 data analysis versão 5.

\subsubsection{Concentrador a Vácuo}

Para a eliminação de solventes e concentração de solutos presentes nas soluções obtidas durante a realização dos ensaios deste trabalho, foi utilizado um concentrador a vácuo da marca miVAC (Ipswich, UK) do tipo modular, composto por uma câmara de concentração (quattro concentrator), um condensador de solvente (speed trap), um módulo de controle de pressão e uma bomba de vácuo. 


\subsubsection{HPLC - PDA}

As análises e purificações realizadas com UV/VIS foram efetuadas em um equipamento da Shimadzu Corporation (Kyoto, Japão) equipado com duas bombas LC-20AT, um detector de arranjo de fotodiodos PDA-20AV, um autoinjetor (Proeminence SIL-20AC) e um forno para colunas (CTO-10AS/VP) controlado por um módulo de comunicação CBM-20A. Os dados foram processados pelo software LC-Solution 1.21 (Shimadzu, Japão). Os sistemas com as condições cromatográficas estão descritos em seção especifica.

\subsubsection{Espectrometria de massas}

As análises por ESI-MS/MS foram realizadas utilizando-se os espectrômetros de massas disponibilizados pelo Prof. Paolo Di Mascio e Profa. Marisa H. G. Medeiros (Instituto de Química da USP - IQUSP). A ionização das moléculas de interesse ocorreu em modo positivo ou negativo, dependendo da análise. A otimização do sistema e as condições de eluição empregadas estão descritas no decorrer do texto. Abaixo seguem as descrições dos equipamentos utilizados.

ESI-MS/MS 1 - Sistema de HPLC da Shimadzu (Kyoto, Japão) equipado com um injetor automático (SIL-10AD/VP), um injector Rheodyne (Cotati, CA), uma válvula automática de comutação de fluxo (FCV-12AH), duas bombas (Class LC 10AD) e um detector de absorbância SPD-10AV/VP, controlados por um módulo de comunicação (SCL-10A/VP-CBM 10A) e pelo software Class-VP (Shimadzu, Japão), acoplado a um espectrômetro de massas Quattro II da empresa Micromass (Manchester, Reino Unido). Os dados foram processados utilizando-se o software MassLynx 3.2 (Micromass, Reino Unido). 
ESI-MS/MS 2 - Sistema de HPLC da Agilent série 1200 (Wilmington, EUA) equipado com uma bomba binária (Agilent 1200 G1312B), uma bomba isocrática (Agilent 1200 G1310A), um forno para coluna (Agilent 1200 G1316B), um detector de absorbância de arranjo de diodos (Agilent 1200 DAD G1315C) e um injetor automático (G1367C Agilent 1200). O sistema de HPLC é integrado a um espectrômetro de massas Linear Quadrupole Ion Trap modelo 4000 QTRAP da empresa Applied Biosystems/MDS Sciex Instruments (Foster City, EUA). Os dados foram processados utilizando o software Analyst 1.6 (Applied Biosystems, EUA).

Ion trap ESI-MS $\mathbf{n}_{\mathbf{n}}$ - Sistema de HPLC da Shimadzu acoplado ao espectrômetro de massas modelo AmaZon Speed (Bruker Daltonics), com fonte ESI, duplo funil de íons e analisador tipo lon Trap.

\subsection{Condições Cromatográficas}

Neste item estão descritas as condições cromatográficas utilizadas no decorrer deste trabalho.

Condição Cromatográfica 1 - Coluna Luna C18 (2) 250 mm x 4,6 mm ID, 5 $\mu \mathrm{m}$ (Phenomenex, Torrance, CA) utilizada com uma pré-coluna C18 4,0 x 3,0 mm (Phenomenex, Torrance, CA) a qual foi eluída com um gradiente de água e metanol (iniciado em 10\%; 0 - 25 min até 100\%; 25 a 35 min permaneceu em $100 \%$; 35 - 36 min até $10 \% ; 36$ - 46 min permaneceu em $10 \%$ ), a $40^{\circ} \mathrm{C}$, com um fluxo de $1 \mathrm{~mL} / \mathrm{min}$. A absorbância foi monitorada no intervalo de 200 a 700 $\mathrm{nm}$. 
Condição Cromatográfica 2 - Coluna Luna C18 (2) 250 mm x 4,6 mm ID, 5 $\mu \mathrm{m}$ (Phenomenex, Torrance, CA) utilizada com uma pré-coluna C18 4,0 x 3,0 mm (Phenomenex, Torrance, CA) a qual foi eluída com um gradiente de água e acetonitrila (iniciado em 10\%; 0 - 25 min até 100\%; 25 a 35 min permaneceu em 100\%; 35 - 36 min até $10 \% ; 36$ - 46 min permaneceu em $10 \%$ ), a $40^{\circ} \mathrm{C}$, com um fluxo de $1 \mathrm{~mL} / \mathrm{min}$. A absorbância foi monitorada no intervalo de 200 a $700 \mathrm{~nm}$.

Condição Cromatográfica 3 - Coluna Luna C18 (2) 250 mm x 4,6 mm ID, 5 $\mu \mathrm{m}$ (Phenomenex, Torrance, CA) utilizada com uma pré-coluna C18 4,0 x 3,0 mm (Phenomenex, Torrance, CA) a qual foi eluída com um gradiente de água e acetonitrila (iniciado em 3\%; 0 - 25 min até $50 \%$; 25 a 35 min até 100\%; 35 - 36 min até $3 \% ; 36-46$ min permaneceu em $3 \%$ ), a $40^{\circ} \mathrm{C}$, com um fluxo de 1 $\mathrm{mL} / \mathrm{min}$. A absorbância foi monitorada no intervalo de 200 a $700 \mathrm{~nm}$.

Condição Cromatográfica 4. Coluna Luna C18 (2) (50 mm x 2 mm id, 2,5 $\mu \mathrm{m}$, Phenomenex, Torrance, CA) com uma pré-coluna C18 4,0 x 3,0 mm (Phenomenex, Torrance, CA) a qual foi eluída com um gradiente de água com 0,1\% de ácido acético e metanol (iniciado em 10\%; 0 - 25 min até 100\%; 25 a 35 min permaneceu em 100\%; 35 - 36 min até 10\%; 36 - 46 min permaneceu em $10 \%$ ), a $40{ }^{\circ} \mathrm{C}$, com fluxo de $0,12 \mathrm{~mL} / \mathrm{min}$. A temperatura da fonte do espectrômetro de massas foi mantida em $100{ }^{\circ} \mathrm{C}$. Espectros de massas em $M S_{1}$ e $M S_{2}$ de fragmentos de íons selecionados foram adquiridos no intervalo de $50-350 \mathrm{~m} / \mathrm{z}$ com diferentes voltagens de cone (20 e $40 \mathrm{~V}$ ). 
Condição Cromatográfica 5. Coluna Luna C18 (2) $250 \mathrm{~mm} \times 4,6 \mathrm{~mm}$ ID, 5 $\mu \mathrm{m}$, (Phenomenex, Torrance, CA) com uma pré-coluna C18 4,0 x 3,0 mm (Phenomenex, Torrance, CA) a qual foi eluída com um gradiente de água com $0,1 \%$ de ácido fórmico e uma solução de metanol: $\mathrm{H}_{2} \mathrm{O}(\mathrm{V} / \mathrm{V})$ com $0,1 \%$ de acido fórmico (0 - $25 \mathrm{~min}, 0-36 \%$ de metanol), a $30^{\circ} \mathrm{C}$, com um fluxo de $1 \mathrm{~mL} / \mathrm{min}$. O detector de PDA foi fixado em $260 \mathrm{~nm}$ para a quantificação dos desoxinucleosídeos. Curvas de calibração foram feitas no intervalo de 0,1 - 8 nmol de dG.

Condição Cromatográfica 6. Coluna Luna C18(2) $(150$ x 2.0 mm i.d., 3.0 m, Phenomenex) com uma pré-coluna C18 4,0 x 3,0 mm (Phenomenex, Torrance, CA) foi eluída com gradiente de ácido fórmico $0,1 \%$ em $\mathrm{H}_{2} \mathrm{O}$ (Solução A) e ácido fórmico $0,1 \%$ em metanol (Solução B), a $35{ }^{\circ} \mathrm{C}$, com fluxo de $130 \mu \mathrm{L} / \mathrm{min}$ (0 - 30 min, $0-50 \%$ de B; $30-31$ min, $50-80 \%$ de B; $31-36$ min, $80 \%$ de B; 36 - 38 min, 80 - $0 \%$ de B; 38 - 48 min, $0 \%$ de B). A válvula de comutação de fluxo foi configurada para permitir a entrada de eluentes no espectrômetro de massas (Sistema ESI-MS/MS 2) no intervalo de 8 - 43 min.

Condição Cromatográfica 7. Foi utilizado um sistema com duas colunas conforme o descrito a seguir. Válvula posição 0: Coluna Luna C18 (2) $50 \mathrm{~mm} \mathrm{x}$ 4,6 mm, ID, $2.6 \mu \mathrm{m}$, (Phenomenex, Torrance, CA) com uma pré-coluna C18 4,0 x 3,0 mm (Phenomenex, Torrance, CA) eluída com um gradiente de ácido fórmico $0,1 \%$ em água (Solução $A$ ) e $0,1 \%$ de ácido fórmico em metanol (Solução B), a um fluxo de $130 \mu \mathrm{L} / \mathrm{min}, 25^{\circ} \mathrm{C}$, nas seguintes condições: 0 - 5 
$\min , 0-4 \%$ de $B ; 5-6 \min , 4 \%$ de $B ; 6-11 \min , 4-7 \%$ de $B ; 11-12 \min , 7$ - $8 \%$ de B; $12-16$ min, $8-10 \%$ de B; $16-25$ min, $10-60 \%$ de B; $25-26$ min, $60-80 \%$ de B; $26-33$ min, $80 \%$ de B; $33-35 \min , 80-0 \%$ de B; $35-$ 50 min, $0 \%$ de B (Linha 1). Concomitantemente uma coluna Luna C18 (2) 150 $\mathrm{mm} \times 2,0 \mathrm{~mm}$, ID, $3 \mu \mathrm{m}$, (Phenomenex, Torrance, CA) foi eluída em modo isocrático por uma solução constituída por 15\% de metanol em água com 0,1\% de ácido fórmico, a um fluxo de $130 \mu \mathrm{L} / \mathrm{min}, 25^{\circ} \mathrm{C}$. O sistema é integrado ao espectrômetro de massas (Sistema ESI-MS/MS 2) (Linha 2). Válvula posição 1: Com a alteração do posicionamento da válvula, as duas linhas descritas acima passam a ser eluidas pelo gradiente da bomba binária e as duas colunas analíticas passam a integrar a mesma linha do sistema cromatográfico (Linha 3). As seguintes condições de posicionamento para a válvula de comutação de fluxo são empregadas: 0 - 13 min, posição 0; 13 - 35 min, posição 1; 35 - 50 min, posição 0. Para as quantificações foram injetadas curvas de calibração no intervalo de 250 a $2000 \mathrm{fmol}$ de $8-0 x o d G\left(1000 \mathrm{fmol}\right.$ de $\left.\left[{ }^{15} \mathrm{~N}_{5}\right] 8-\mathrm{oxodG}\right)$ e 2 a $100 \mathrm{fmol}$ de CEdG (200 fmol de $\left.\left[{ }^{15} \mathrm{~N}_{5}\right] \mathrm{CEdG}\right)$.

Condição Cromatográfica 8. Coluna Syncronis HILIC (2) $150 \mathrm{~mm} \times$ 4,6 mm, ID, $5 \mu \mathrm{m}$, (Thermo Scientific, USA) com uma pré-coluna HILIC 4,0 x 3,0 mm (Thermo Scientific, USA) foi eluída com um gradiente de acetonitrila (Solução A) e tampão acetato de amônio $5 \mathrm{mM}$ com $0.05 \%$ de hidróxido de amônio (Solução B), a um fluxo de $300 \mu \mathrm{L} / \mathrm{min}, 35^{\circ} \mathrm{C}$, nas seguintes condições: 0 - 35 $\min , 0-40 \%$ B; $35-36 \min , 40-0 \%$ B; $36-56 \min , 0 \%$ B. A válvula de comutação de fluxo foi configurada para permitir a entrada de eluentes no espectrômetro de massas (Sistema ESI-MS/MS 2) no intervalo de 16 - 27 min. 
Condição Cromatográfica 9. Coluna Luna C18 (2) $250 \mathrm{~mm}$ x 4,6 mm, ID, 5 $\mu \mathrm{m}$, (Phenomenex, Torrance, CA) com uma pré-coluna C18 4,0 x 3,0 mm (Phenomenex, Torrance, CA) eluída com um gradiente de água (Solução A) e acetonitrila (Solução B), ambas suplementadas com ácido acético (0,2\%; v/v), a $30^{\circ} \mathrm{C}$, com fluxo de $1 \mathrm{~mL} / \mathrm{min}(0-28 \mathrm{~min}, 20-100 \%$ de B; $28-30 \mathrm{~min}, 100-$ $20 \%$ de B; 30 - 40 min, $20 \%$ de B). O detector PDA foi fixado em 306 nm para o monitoramento do produto MDA-DNPH. Curvas de calibração foram feitas no intervalo de $25-1200$ pmol de MDA.

\subsection{Síntese de 3-nitro-bisfenol A (BPANO $\left.{ }_{2}\right)$ e 3,3'-dinitro-bisfenol A $\left(\mathrm{BPA}\left(\mathrm{NO}_{2}\right)_{2}\right)$}

Para a síntese de $\mathrm{BPANO}_{2}$ e $\mathrm{BPA}\left(\mathrm{NO}_{2}\right)_{2}$ foi utilizado o método descrito por Schrader et al., 2002. BPA ( $5 \mathrm{mg} / \mathrm{mL}$ em DMSO, $1 \mathrm{~mL}$ ) foi adicionado a 2 $\mathrm{mL}$ de tampão acetato de sódio $0,2 \mathrm{M}, \mathrm{pH} 4$ e $1 \mathrm{~mL}$ de nitrito de sódio $0,9 \mathrm{M}$ preparado no mesmo tampão. A solução foi incubada por $1 \mathrm{~h}$ a $37{ }^{\circ} \mathrm{C}$, sob agitação. Em seguida, alíquotas foram analisadas por HPLC-PDA, utilizando a condição cromatográfica 1 . Os produtos correspondentes ao $\mathrm{BPANO}_{2}$ e $\mathrm{BPA}\left(\mathrm{NO}_{2}\right)_{2}$ foram coletados, liofilizados e ressuspensos em $200 \mu \mathrm{l}$ de água/metanol (1:1) para análises por espectrometria de massas (Sistema ESIMS/MS 1 e 3, item 3.1.5).

\subsection{Síntese de bisfenol A-3,4-quinona (BPA-3,4-quinona)}

Para a síntese de BPA-3,4-quinona foi utilizado o método descrito por Qiu, Yang et al. (2004). BPA (10 mg) dissolvido em $600 \mu \mathrm{l}$ de éter que foi 
adicionado a uma solução de nitrosodissulfonato de potássio (sal de Fremy, 30 mg em $10 \mathrm{~mL}$ de tampão fosfato de sódio $50 \mathrm{mM}, \mathrm{pH}$ 7) e a solução resultante agitada por 20 min à temperatura ambiente. O produto da incubação foi submetido a extração com $5 \mathrm{ml}$ de clorofórmio por 3 vezes, a solução resultante foi submetida a lavagem com $5 \mathrm{ml}$ de água por 3 vezes. A fase orgânica foi coletada e concentrada em speedy vac. O produto resultante foi ressuspenso em acetona e uma alíquota submetida à análise por HPLC-PDA (condição cromatográfica 2). O produto correspondente ao BPA-3,4-quinona $\left(\lambda_{\text {máx. }}=386 \mathrm{~nm}\right)$ foi coletado, liofilizado e ressuspenso em água/metanol (1:1) para análise por HPLC-ESI-MS/MS no modo negativo (condição cromatográfica 4).

\subsection{Síntese do aduto de BPA-3,4-quinona com 2'-desoxiguanosina (dGuo)}

Para a síntese do aduto $3-\mathrm{OH}-\mathrm{BPA}-\mathrm{N}^{7} \mathrm{dGuo}$, foi utilizado o método descrito por Qiu et al., 2004. Uma alíquota (200 $\mu \mathrm{L})$ do produto bruto obtido em acetona após oxidação do BPA com sal de Fremy foi adicionada a uma solução de dGuo (2 mg em $800 \mu \mathrm{L}$ de água/acetona 1:1) e a solução resultante foi incubada sob agitação a $37{ }^{\circ} \mathrm{C}$ por $6 \mathrm{~h}$. A solução foi então liofilizada e ressuspensa em água/acetonitrila (1:1) para análises por HPLC-PDA, utilizando a condição cromatográfica 3 .

O mesmo procedimento foi utilizado nas incubações com $\left[{ }^{15} \mathrm{~N}_{5}\right] \mathrm{d} G u o$, obtendo-se o padrão isotópico do aduto.

O produto correspondente ao aduto de BPAQ com dGuo, com $\lambda_{\max }$ em $284 \mathrm{~nm}$, foi coletado, liofilizado e ressuspenso em $200 \mu \mathrm{L}$ de uma solução de 
água/acetonitrila (v/v). A identidade do aduto foi confirmada por espectrometria de massas no modo positivo, por infusão direta no sistema lon trap ESI-MS descrito no item 3.1.5.

\subsection{Quantificação do aduto BPA-Gua em DNA}

Uma alíquota $(200 \mu \mathrm{L})$ do produto bruto obtido em acetona após oxidação do BPA com sal de Fremy (item 3.4) foi adicionada a uma solução de DNA de timo de bezerro obtido da Sigma (4 mg em $1600 \mu \mathrm{L}$ de água) e a solução resultante foi incubada sob agitação a $37^{\circ} \mathrm{C}$ por $6 \mathrm{~h}$. Ao final foram realizadas 2 extrações com clorofórmio e o DNA precipitado utilizando-se $\mathrm{NaCl} 3 \mathrm{M}$ e etanol. O DNA recuperado foi lavado duas vezes com etanol $70 \%$, solubilizado em água e congelado até a realização da hidrólise neutra-térmica, como descrito abaixo. Para comparação, uma alíquota da mesma amostra de DNA foi submetida ao procedimento de hidrólise sem a incubação por $1 \mathrm{~h}$ a $70{ }^{\circ} \mathrm{C}$, a fim de se verificar a possibilidade de o aduto ser liberado do DNA em condições brandas de manipulação.

Para a hidrólise neutra-térmica, o DNA $(300 \mu \mathrm{g})$ dissolvido em água $\left(\mathrm{V}_{\mathrm{f}}=\right.$ $500 \mu \mathrm{L}$ ) foi aquecido a $70{ }^{\circ} \mathrm{C}$ por $1 \mathrm{~h}$ na presença de $1600 \mathrm{fmol}$ do padrão interno $\left[{ }^{15} \mathrm{~N}_{5}\right] \mathrm{BPA}-\mathrm{Gua}$. Após esse período foi retirada uma alíquota de $25 \mu \mathrm{L}$ para a realização de hidrólise ácida e quantificação de Gua. O restante do volume foi seco sob vácuo, ressuspenso em metanol (500 $\mu \mathrm{L})$, centrifugado, e

o sobrenadante novamente seco sob vácuo. Ao final, o precipitado foi ressuspenso em $76 \mu \mathrm{L}$ de água e o volume de $50 \mu \mathrm{L}$ (contendo $1000 \mathrm{fmol}$ de $\left[{ }^{15} \mathrm{~N}_{5}\right]$ BPA-Gua) foi injetado no sistema de HPLC-ESI-MS/MS (Condição cromatográfica 6, Sistema ESI-MS/MS 2) 


\subsection{Curva de crescimento das linhagens celulares HL-60 e MCF-7}

Inicialmente as duas linhagens celulares $\left(5 \times 10^{5}\right.$ células por poço) em placas de 24 poços foram cultivadas em estufa umidificada a $37^{\circ} \mathrm{C}$ e $5 \%$ de $\mathrm{CO}_{2}$, pelos períodos de $0,24,48$ e 72 horas em meio RPMI suplementado com $10 \%$ de soro fetal bovino (FBS) ou DMEM suplementado com $10 \%$ de FBS para as linhagens HL-60 e MCF-7, respectivamente. Após cada período de 24 horas as células foram retiradas de cultivo e levadas a centrifugação (600 x $\left.\mathrm{g} / 37^{\circ} \mathrm{C} / 10 \mathrm{~min}\right)$, o sobrenadante foi descartado e o pellet de células foi ressuspenso em $10 \mathrm{~mL}$ de um novo meio de cultura. Uma alíquota de $10 \mu \mathrm{L}$ da suspenção celular foi retirada e diluída em $90 \mu \mathrm{L}$ de azul de tripam $0,4 \%$ (Sigma-Aldrich, St. Louis, MO). Dessa diluição, $10 \mu \mathrm{L}$ foram utilizados para contagem das células e construção da curva de crescimento celular.

\subsection{Viabilidade celular}

Células da linhagem MCF-7 foram plaqueadas na densidade de $5 \times 10^{4}$ células por poço $(200 \mu \mathrm{L})$ em placas de cultura de 96 poços. Após o período de adesão (24 horas), o meio de cultura foi substituído por um novo meio DMEM livre de fenol suplementado com $10 \%$ FBS contendo $25 \mu \mathrm{M}, 100 \mu \mathrm{M}$ ou $250 \mu \mathrm{M}$ de BPA ou $\mathrm{BPANO}_{2}$, dissolvido em DMSO $(0,1 \%$, v/v). Incubações controle foram feitas com $0,1 \%$ de DMSO (controle veículo). As células foram expostas pelo período de 1 ou 24 horas. 
Após o término do período de exposição, o meio de cultura foi removido e as células foram cuidadosamente lavadas com PBS a temperatura de $37^{\circ} \mathrm{C}$, por duas vezes.

Células HL-60, cultivadas em suspensão, foram plaqueadas na densidade de $5 \times 10^{4}$ células por poço $(200 \mu \mathrm{L})$ em placa de cultura de 96 poços, diluídas em meio RPMI suplementado com 10\% de FBS contendo 25 $\mu \mathrm{M}, 100 \mu \mathrm{M}$ ou $250 \mu \mathrm{M}$ de BPA ou BPANO${ }_{2}$, dissolvido em DMSO $(0,1 \%, v / v)$, na presença ou ausência de $\mathrm{H}_{2} \mathrm{O}_{2}\left(40 \mathrm{nmol} / 5 \times 10^{4}\right.$ células). Incubações controle foram feitas com $0,1 \%$ de DMSO (controle veículo). As células foram expostas pelo período de 2 ou 24 horas. A quantidade utilizada de $\mathrm{H}_{2} \mathrm{O}_{2}$ foi definida com base no trabalho de Cuddihy et al., 2008, tendo sido feita a adição à suspensão de células $1 \mathrm{~h}$ após o início das incubações.

Após o período de exposição, células MCF-7 e HL-60 foram lavadas com PBS, transferidas para tubos de citometria e submetidas à centrifugação (600 $\left.\mathrm{xg} / 4^{\circ} \mathrm{C} / 10 \mathrm{~min}\right)$. $\mathrm{O}$ sobrenadante foi descartado e o pellet de células foi ressuspenso em $200 \mu \mathrm{L}$ de uma solução de PBS contendo iodeto de propídeo (PI - Sigma-Aldrich, St. Louis, MO) na concentração de $50 \mu \mathrm{g} / \mathrm{mL}$. Após a ressuspensão, as células foram imediatamente levadas para leitura em citômetro de fluxo.

Foi avaliada a intensidade de fluorescência do iodeto de propídio ligado ao DNA de 10.000 eventos por amostra, monitorados no canal PerCP-Cy 5.5 $\left(\lambda_{\text {exc. }}=488 \mathrm{~nm} ; \lambda_{\text {emi. }}=695 \mathrm{~nm}\right)$. Apenas as células com alteração da permeabilidade da membrana plasmática apresentam fluorescência. 


\subsection{Ensaio do XTT}

Com o intuito de verificar se BPA e $\mathrm{BPANO}_{2}$ interferem na cadeia de transporte de elétrons mitocondrial, alterando a atividade da succinato desidrogenase e, assim, levando à perda de viabilidade celular, as células HL60 foram expostas a BPA ou $\mathrm{BPANO}_{2}$ como descrito anteriormente por $24 \mathrm{~h}$ e em seguida submetidas ao ensaio do XTT utilizando o kit da empresa Xenometrix. Após o término do período de exposição, o meio de cultura foi removido, as células foram cuidadosamente lavadas com solução salina fosfato tamponada (PBS) pH 7,0 e um novo meio de cultura com 5\% de SFB (200 $\mu \mathrm{L} /$ poço) foi adicionado à placa. Uma solução pré-formulada de $50 \mu \mathrm{L}$ do reagente XTT (reagente XTT: tampão $=100: 1$ ) foi então adicionada a cada poço e a placa de cultura foi incubada por $1 \mathrm{~h}$ a $37^{\circ} \mathrm{C}, 5 \%$ de $\mathrm{CO}_{2}$. Os valores da absorbância (OD = OD450nm-OD690nm) foram aferidos fazendo a leitura no comprimento de onda de $450 \mathrm{~nm}$, com a leitura de referência no comprimento de onda de $690 \mathrm{~nm}$. Os resultados foram expressos em porcentagem relativa ao grupo controle.

\subsection{Determinação da geração intracelular de espécies reativas de oxigênio (ERO) e nitrogênio (ERN)}

Sondas fluorogênicas são ferramentas convenientes e sensíveis para a detecção de oxidantes intracelulares. A indução de estresse oxidativo foi monitorada quantitativamente por análise de fluorescência do produto 2',7'diclorofluoresceína (DCF) resultante da oxidação de 2',7'diclorodihidrofluoresceína (DCFH) intracelularmente. Para tanto, células HL-60 
foram incubadas com BPA ou $\mathrm{BPANO}_{2}(25 \mu \mathrm{M}, 100 \mu \mathrm{M}, 250 \mu \mathrm{M})$ pelo período de 1 hora. Em seguida, as células foram transferidas para tubos de citometria e submetidas à centrifugação $\left(600 \times \mathrm{g} / 10 \mathrm{~min} / 4^{\circ} \mathrm{C}\right)$. $\mathrm{O}$ sobrenadante foi descartado e o pellet de células foi lavado duas vezes com $1 \mathrm{~mL}$ de PBS. Após a última lavagem, o sobrenadante foi descartado e o pellet de células foi ressuspenso em $200 \mu \mathrm{L}$ de 2',7'-diclorofluorescina-diacetato (DCFH-DA, 3 mM), o qual se acumula no citosol e é desacetilado por esterases para 2',7'diclorodihidrofluoresceína que pode ser, então, oxidado por radicais livres gerados intracelularmente, como $\mathrm{RO}_{2}^{\circ}, \mathrm{RO}^{\circ}, \mathrm{NO}_{2}{ }^{\circ}, \mathrm{CO}_{3}{ }^{-}$e $\mathrm{HO}$. O volume final das amostras foi completado para $1100 \mu \mathrm{L}$ com PBS. As células foram incubadas a $37^{\circ} \mathrm{C}$ por 30 minutos e, ao fim da incubação, $2 \mathrm{~mL}$ de EDTA (3 $\mathrm{mM})$ a $4^{\circ} \mathrm{C}$ foram adicionados. As soluções foram centrifugadas $(600 \mathrm{~g} / 10 \mathrm{~min} /$ $4^{\circ} \mathrm{C}$ ), os sobrenadantes descartados e os pellets ressuspensos em $100 \mu \mathrm{L}$ de PBS. Para verificar se a estimulação de MPO por $\mathrm{H}_{2} \mathrm{O}_{2}$ teria efeito sobre a geração de EROs/ERNs, parte das amostras foi incubada por 5 min com $\mathrm{H}_{2} \mathrm{O}_{2}$ (40 nmol / $5 \times 10^{4}$ células) antes das análises por citometria de fluxo. Foi avaliada a intensidade de fluorescência $\left(\lambda_{\text {emi. }}=530 \mathrm{~nm}\right.$ com $\left.\lambda_{\text {exc. }}=488 \mathrm{~nm}\right)$ de 10.000 eventos por amostra.

O mesmo procedimento de exposição foi aplicado às células MCF-7. Após o período de exposição, o meio de cultura (DMEM com 10\% FBS, livre de fenol) contendo BPA ou $\mathrm{BPANO}_{2}$ foi removido e as células lavadas com PBS. Uma solução de PBS contendo $10 \mu \mathrm{M}$ de DCFH foi adicionada às células e levadas a incubação por 30 minutos a temperatura ambiente e ao abrigo de luz. Em seguida, as células foram levadas para leitura, segundo descrito por Renz, 
Volz et al. (2013). A intensidade de emissão de fluorescência foi mensurada a $\lambda_{\text {emi. }}=530 \mathrm{~nm}$ com $\lambda_{\text {exc. }}=488 \mathrm{~nm}$, no leitor de ELISA.

\subsection{Determinação de $\mathrm{NO}_{2}$ no meio de cultura das células $\mathrm{HL}-60$}

A concentração de $\mathrm{NO}_{2}$ - foi determinada no sobrenadante da cultura de células HL-60 utilizando a reação de GRIESS. Para tanto, $100 \mu \mathrm{L}$ do sobrenadante da cultura celular foram adicionados a $100 \mu \mathrm{L}$ do reagente de GRIESS (1\% sulfanilamida com $0,1 \%$ de $\alpha$-naftil etilenodiamina) em microplaca de 96 poços e a solução resultante incubada por 10 minutos à temperatura ambiente. Após esse período foi feita a leitura de absorbância em 550 nm. A concentração de $\mathrm{NO}_{2}$ - foi determinada a partir de uma curva padrão de nitrito de sódio $\left(\mathrm{NaNO}_{2}\right)$ na faixa de $0,2-200 \mu \mathrm{M}$.

\subsection{Análise de fragmentação do DNA e ciclo celular}

Para a análise concomitante de fragmentação do DNA e ciclo celular das células HL-60 e MCF-7, $25 \times 10^{5}$ células foram plaqueadas em placas de 24 poços com meio de cultura RPMI ou DMEM suplementado com $10 \%$ FBS. Após o período de adesão celular (24 horas), pertinente às células MCF-7, o meio de cultura das duas linhagens foi substituído por um novo meio de cultura livre de fenol contendo $25 \mu \mathrm{M}, 100 \mu \mathrm{M}$ ou $250 \mu \mathrm{M}$ de BPA ou $\mathrm{BPANO}_{2}$, dissolvido em DMSO $(0,1 \%, v / v)$ com ou sem $\mathrm{H}_{2} \mathrm{O}_{2}\left(40 \mathrm{nmol} / 5 \times 10^{4}\right.$ células $)$ quando se tratar da linhagem HL-60.

Ao término de 24 horas de exposição, o meio de cultura das células MCF-7 foi removido, as células foram lavadas duas vezes com PBS e 
tripsinizadas (300 $\mu \mathrm{L} /$ poço). Após 1 minuto de contato, foram adicionados 1000 $\mu \mathrm{L}$ de meio de cultura DMEM livre de fenol suplementado com $10 \%$ FBS.

As células MCF-7 e HL-60 foram homogeneizadas, transferidas para tubos de citometria e centrifugadas $\left(600 \times \mathrm{g} / 10 \mathrm{~min} / 4{ }^{\circ} \mathrm{C}\right)$. $\mathrm{O}$ sobrenadante foi desprezado e o pellet de células foi lavado duas vezes com PBS. Após as lavagens foram adicionados a cada tubo $50 \mu \mathrm{L}$ de uma solução contendo a enzima RNAse A (15 mg/mL) e $150 \mu \mathrm{L}$ do tampão hipotônico fluorescente (PBS, 0,05\% Triton X-100, 0,1\% de citrato de sódio, $25 \mu \mathrm{g} / \mathrm{mL}$ de iodeto de propídio). As amostras foram incubadas por 30 minutos à temperatura ambiente e as análises foram realizadas por citometria de fluxo. Foi avaliada a intensidade de fluorescência do iodeto de propídio ligado ao DNA de 10.000 eventos por amostra, monitorados no canal PerCP-Cy $5.5\left(\lambda_{\text {exc. }}=488 \mathrm{~nm} ; \lambda_{\text {emi. }}\right.$. $=695 \mathrm{~nm})$.

\subsection{Determinação da atividade de MPO em células HL-60}

Para a análise da atividade de MPO, $25 \times 10^{5}$ células HL-60 foram plaqueadas em placa de 24 poços $(1000 \mu \mathrm{L})$ e expostas ao meio de cultura RPMI suplementado com 10\% FBS, contendo $25 \mu \mathrm{M}, 100 \mu \mathrm{M}$ ou $250 \mu \mathrm{M}$ de BPA ou $\mathrm{BPANO}_{2}$, dissolvido em DMSO $(0,1 \%, \mathrm{v} / \mathrm{v})$, na presença ou ausência de $\mathrm{H}_{2} \mathrm{O}_{2}\left(40 \mathrm{nmol} / 5 \times 10^{4}\right.$ células) durante 2 ou 24 horas, como explicado anteriormente. Ao término do período de exposição, a suspensão de células foi transferida para tubos de $1,5 \mathrm{~mL}$. Subsequentemente, as amostras foram centrifugadas $\left(600 \times \mathrm{g} / 10 \mathrm{~min} / 37^{\circ} \mathrm{C}\right)$ e as células lavadas duas vezes com PBS. 
Após a última centrifugação, o sobrenadante foi descartado e o pellet de células ressuspenso em $500 \mu \mathrm{L}$ de brometo de hexadeciltrimetilamonio (HTAB 0,5\% em água - Sigma-Aldrich, St. Louis, MO). As células foram imediatamente congeladas em nitrogênio líquido e descongeladas em água a $37^{\circ} \mathrm{C}$ e posteriormente vortexadas vigorosamente durante 20 segundos. Este procedimento foi repetido por três vezes para a lise das células e liberação da MPO.

A suspensão de células resultante foi levada à estufa a $60^{\circ} \mathrm{C}$ por 2 horas para inativação da catalase. Em seguida, as amostras foram centrifugadas a $10.000 \mathrm{rpm}$ durante $2 \mathrm{~min}$. O sobrenadante foi utilizado para determinação da atividade de MPO e o precipitado proteico utilizado para determinação da quantidade de proteínas por ensaio de Bradford.

Para realização do ensaio cinético empregado na determinação da atividade da enzima, foram acrescentados $10 \mu \mathrm{L}$ do sobrenadante a $200 \mu \mathrm{L}$ da solução reagente (o-dianisidina, $\mathrm{H}_{2} \mathrm{O}_{2}$ a $0,0005 \%$, em tampão fosfato $5 \mathrm{mM}, \mathrm{pH}$ $6,0)$ em uma microplaca. As amostras foram levadas ao espectrofotômetro

(Spectra Max Plus ${ }^{-}$Molecular Devices, Chicago, IL, USA) para a monitorização da velocidade de formação do produto de oxidação da odianisidina, através do registro do aumento da absorbância a 460 nm.

\subsection{Ensaio EROD para verificação da atividade de CYP1A1 em células MCF-7}

Para a determinação da atividade de CYP1A1 em células MCF-7 foi utilizado um método adaptado de Barbara e colaboradores (Spink, Hussain et al. 2003). 
Para tanto células MCF-7 $\left(1 \times 10^{4}\right)$ foram cultivadas em meio DMEM com $10 \%$ SFB em placa de 96 poços. Após atingirem a confluência o meio foi substituído por um novo, contendo BPA na concentrações de 25, 100, $250 \mu \mathrm{M}$ e incubados em estufa por 24 horas. Ao final do período de exposição o meio foi removido e um novo meio contendo $4 \mu \mathrm{M}$ de ethoxyresorufina (sigma) e $10 \mu \mathrm{M}$ de dicumarol (3,3'-Metileno-bis(4-hidroxicoumarina)). A placa contendo o novo meio foi incubada em estufa por mais 30 minutos. Em seguida a fluorescência foi medida em $\lambda_{\text {emissão }}=590 \mathrm{~nm}$ e $\lambda_{\text {excitação }}=535 \mathrm{~nm}$ (em ponto final). Controles positivos foram adotados com $10 \mathrm{nM}$ de PCB126 (3,3',4,4',5Pentachlorobiphenyl) como ativador do CYP.

\subsection{Análises da concentração de BPA no meio de cultura das células}

Alíquotas de $50 \mu \mathrm{L}$ do meio de cultura das células, após diferentes períodos de incubação com BPA, foram injetadas no sistema de HPLC-PDA, utilizando-se a condição cromatográfica 1. O BPA eluiu da coluna em $\sim 21,5$ min nas condições utilizadas, sendo monitorado em $277 \mathrm{~nm}$.

\subsection{Quantificação de malonaldeído no meio de cultura por HPLC-PDA}

Para a quantificação de MDA no meio de cultura, as células HL-60 foram plaqueadas na densidade de $5 \times 10^{5}$ células/poço em placas de cultura de 6

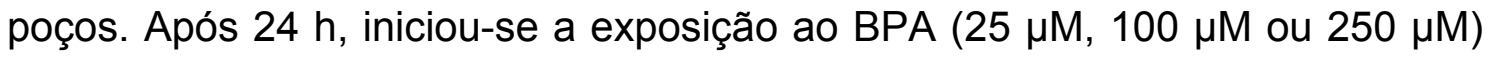
dissolvido em DMSO $\left(0,1 \%\right.$, v/v), na presença ou ausência de $\mathrm{H}_{2} \mathrm{O}_{2}(40 \mathrm{nmol} /$ $5 \times 10^{4}$ células). Incubações controle foram feitas com $0,1 \%$ de DMSO (controle veículo). As células foram expostas pelo período de 24 horas. Alíquotas do 
meio de cultura $(100 \mu \mathrm{L})$ foram hidrolisadas para obtenção do MDA livre de proteínas pela adição de $10 \mu \mathrm{L}$ de $\mathrm{NaOH} 4 \mathrm{M}$ com subsequente incubação a 60 ${ }^{\circ} \mathrm{C}$ por 30 min sob agitação de $100 \mathrm{rpm}$. Ao término da incubação, $150 \mu \mathrm{L}$ de $\mathrm{H}_{2} \mathrm{SO}_{4} 1 \%(\mathrm{v} / \mathrm{v})$ foram adicionados e as amostras foram submetidas à vigorosa agitação por 20 segundos com posterior centrifugação a $9.300 \mathrm{~g}$ por $10 \mathrm{~min}$. Após a centrifugação, $175 \mu \mathrm{L}$ do sobrenadante foram coletados e incubados com $25 \mu \mathrm{L}$ de uma solução de 2,4-dinitrofenilhidrazina (DNPH, $1 \mathrm{mg} / \mathrm{mL}$ em $\mathrm{HCl}$ 2M). A reação de derivatização ocorreu em temperatura ambiente, ao abrigo da luz, durante $30 \mathrm{~min}$. Alíquotas de $100 \mu \mathrm{L}$ foram injetadas no sistema de HPLC-PDA (condição cromatográfica 9).

O padrão de MDA foi preparado pela adição de $22 \mu \mathrm{L}$ de uma solução de 1,1,3,3-tetrametoxipropano a $10 \mathrm{~mL}$ de $\mathrm{H}_{2} \mathrm{SO}_{4} 1 \%(\mathrm{v} / \mathrm{v})$. Após a incubação ( $2 \mathrm{~h}$, temperatura ambiente, no escuro) a concentração da solução foi calculada através da determinação da absorbância em $\mathrm{H}_{2} \mathrm{SO}_{4} 1 \%$ (v/v), utilizando o respectivo coeficiente de extinção molar $(\varepsilon)$ : MDA, $\varepsilon=13700 \mathrm{M}^{-1} \mathrm{~cm}^{-1}$ em 245 $\mathrm{nm}$.

\subsection{Adutos de DNA no meio de cultura}

As células cultivadas em placas de cultura de $15 \mathrm{~cm}$ de diâmetro (densidade aproximada de $1 \times 10^{7}$ células) foram expostas ao $\mathrm{BPA}$ ou $\mathrm{BPANO}_{2}$ $(25 \mu \mathrm{M}, 100 \mu \mathrm{M}$ ou $250 \mu \mathrm{M})$, dissolvidos em DMSO $(0,1 \%, v / v)$, na presença ou ausência de $\mathrm{H}_{2} \mathrm{O}_{2}$ (40 nmol / $5 \times 10^{4}$ células), como descrito anteriormente. Ao final, foram adicionados às alíquotas do meio de cultura, $2 \mu \mathrm{L}$ da solução contendo $75 \mathrm{fmol} / \mu \mathrm{L}$ de $\left[{ }^{15} \mathrm{~N}_{5}\right] \mathrm{CEdG},\left[{ }^{15} \mathrm{~N}_{5}\right] 1, N^{6}-\varepsilon \mathrm{dA}$ e $\left[{ }^{15} \mathrm{~N}_{5}\right] 1, N^{2}-\varepsilon \mathrm{dG}$, e $1,5 \mu \mathrm{L}$ da solução contendo $1000 \mathrm{fmol} / \mu \mathrm{L}$ de $\left[{ }^{15} \mathrm{~N}_{5}\right] 8-0 x o d G$. As amostras foram então 
homogeneizadas em vórtex e secas completamente a vácuo. Posteriormente, adicionou-se $1 \mathrm{~mL}$ de metanol às amostras, que foram novamente homogeneizadas em vórtex e centrifugadas por $10 \mathrm{~min}$ a $16.000 \mathrm{~g}$. O sobrenadante foi então transferido para outro tubo para nova secagem completa a vácuo. As amostras foram então ressuspensas em $75 \mu \mathrm{L}$ de $\mathrm{H}_{2} \mathrm{O}$ e centrifugadas por 5 min a $16.000 \mathrm{~g}$. Por fim, foram injetados $50 \mu \mathrm{L}$ no sistema HPLC-ESI-MS/MS 2, condição cromatográfica 6. As análises foram conduzidas com ionização por electrospray em modo positivo $\left(\mathrm{ESI}^{+},[\mathrm{M}+\mathrm{H}]^{+}\right)$, utilizando-se os seguintes parâmetros otimizados: gás de interface (CUR), 15 psi; gás de nebulização (GS1), 45 psi; gás na fonte de íons (GS2), 50 psi; gás de dissociação induzida por colisão (CAD), LOW; temperatura da fonte do ESI (TEM), $650^{\circ} \mathrm{C}$; potencial de entrada (EP), $10 \mathrm{~V}$ e tensão do spray de íons (IS), 5500 V. Foi utilizado o modo de monitoramento de reação múltipla (MRM) para detecção e quantificação das lesões, sendo utilizadas as seguintes fragmentações: $m / z 276[\mathrm{M}+\mathrm{H}]^{+} \rightarrow m / z 160\left[\mathrm{M}-2^{\prime} \text {-desoxirribose }+\mathrm{H}\right]^{+}$e $m / z$ $281[\mathrm{M}+\mathrm{H}]^{+} \rightarrow m / z 165\left[\mathrm{M}-2^{\prime}-\right.$ desoxirribose $+\mathrm{H}^{+}$para detecção de 1,N6EdAdo e respectivo padrão interno $\left[{ }^{15} \mathrm{~N}_{5}\right] 1, N^{6}-\varepsilon d A d o ; m / z 292[\mathrm{M}+\mathrm{H}]^{+} \rightarrow m / z 176$ $[\mathrm{M} \text { - 2'- desoxirribose }+\mathrm{H}]^{+}$e $m / z 297[\mathrm{M}+\mathrm{H}]^{+} \rightarrow m / z 181[\mathrm{M}$ - 2'- desoxirribose $+\mathrm{H}]^{+}$para detecção de $1, N^{2}-\varepsilon d G u o$ e respectivo padrão interno $\left[{ }^{15} N_{5}\right] 1, N^{2}-$ $\varepsilon d G u o ; m / z 284[\mathrm{M}+\mathrm{H}]^{+} \rightarrow m / z 168\left[\mathrm{M}-2^{\prime}-\right.$ desoxirribose $+\mathrm{H}^{+}$e $m / z 289$ $[\mathrm{M}+\mathrm{H}]^{+} \rightarrow m / z 173\left[\mathrm{M}-2^{\prime}\right.$ - desoxirribose $+\mathrm{H}^{+}$para deteç̧ão de 8-oxodGuo e respectivo padrão interno $\left[{ }^{15} \mathrm{~N}_{5}\right] 8$-oxodGuo; $\mathrm{m} / \mathrm{z} 340[\mathrm{M}+\mathrm{H}]^{+} \rightarrow \mathrm{m} / \mathrm{z} 224\left[\mathrm{M}-2^{\prime}-\right.$ desoxirribose $+\mathrm{H}]^{+}$e $m / z 345[\mathrm{M}+\mathrm{H}]^{+} \rightarrow m / z 229\left[\mathrm{M}-2^{\prime} \text { - desoxirribose }+\mathrm{H}\right]^{+}$ para detecção de CEdG e respectivo padrão interno $\left[{ }^{15} \mathrm{~N}_{5}\right]$ CEdG; $m / z 282$ $[\mathrm{M}+\mathrm{H}]^{+} \rightarrow m / z 166\left[\mathrm{M}-2^{\prime} \text {-desoxirribose }+\mathrm{H}\right]^{+}$e $m / z 297[\mathrm{M}+\mathrm{H}]^{+} \rightarrow m / z 181[\mathrm{M}-$ 
2'- desoxirribose $+\mathrm{H}^{+}$para detecção de $O^{6}-\mathrm{mdG}$ e respectivo padrão interno

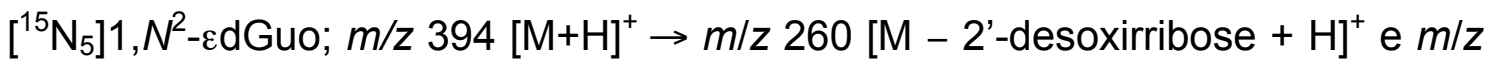
$399[\mathrm{M}+\mathrm{H}]^{+} \rightarrow m / z 265\left[\mathrm{M}-2^{\prime}-\right.$ desoxirribose $+\mathrm{H}^{+}$para deteç̧ão de BPA-Gua e respectivo padrão interno $\left[{ }^{15} \mathrm{~N}_{5}\right] \mathrm{BPA}-G u a$. As razões entre as áreas (aduto/padrão interno) foram utilizadas para quantificação. Para as quantificações foram injetadas curvas de calibração no intervalo de 50 a 1000 fmol de 8-oxodG (1000 fmol de $\left[{ }^{15} \mathrm{~N}_{5}\right] 8$-oxodG); 5 a 80 fmol de CEdG; 1 a 20 fmol de $1, N^{6}-\varepsilon d A ; 1$ a $40 \mathrm{fmol}$ de $1, N^{2}-\varepsilon d G ; 1$ a $100 \mathrm{fmol}$ de $O^{6}$-mdG (100 fmol de $\left[{ }^{15} N_{5}\right]$ CEdG, $\left[{ }^{15} N_{5}\right] 1, N^{6}-\varepsilon d A$ e de $\left.\left[{ }^{15} N_{5}\right] 1, N^{2}-\varepsilon d G\right) ;$ e 10 a 1000 fmol de BPAGua $\left(1000 \mathrm{fmol}\right.$ de $\left[{ }^{15} \mathrm{~N}_{5}\right] \mathrm{BPA}-\mathrm{Gua}$.

\subsection{Adutos de DNA em urina}

O mesmo método descrito no item 3.17 foi aplicado para as análises dos adutos de DNA em amostras de urina, sendo apenas modificado o volume inicial de amostra utilizado, que foi de $100 \mu \mathrm{L}$. Para a coleta de urina, os animais (modelo experimental descrito abaixo) permaneceram em gaiolas metabólicas pelo período de $10 \mathrm{~h}$.

\subsection{Extração de DNA das células}

Após o período de incubação, as células foram transferidas para um tubo de $15 \mathrm{~mL}$ e levadas à centrifugação $\left(600 \times \mathrm{g} / 10 \mathrm{~min} / 37^{\circ} \mathrm{C}\right) . \mathrm{O}$ sobrenadante foi desprezado e o pellet de células foi utilizado para extração do DNA de acordo com o protocolo de extração da Gentra Puregene® (QIAGEN 
Sciences, USA), acrescentando-se $0,5 \mathrm{mM}$ de desferoxamina/10 mM de Dpenicilamina às soluções do kit.

\subsection{Extração de DNA de fígado e rim dos animais}

Foi utilizada uma etapa de lise das células e precipitação dos núcleos utilizando tampão A (320 mM sacarose, $5 \mathrm{mM} \mathrm{MgCl}$, $10 \mathrm{mM}$ Tris, $0,1 \mathrm{mM}$ desferoxamina, 1\% Triton X-100 em pH final de 7,5), sendo incluído $10 \mathrm{mM}$ da solução de D-penicilamina em dois momentos do protocolo: na solução de lise das células e na solução de estocagem com desferoxamina a fim de evitar formação artefatual de lesões. Portanto, para $300 \mathrm{mg}$ de tecido foram adicionados $6 \mathrm{~mL}$ de tampão A. Após homogeneização, centrifugou-se a amostra a 1500 x g por 10 minutos e o sobrenadante foi descartado. Repetiuse o procedimento. Então, adicionou-se ao pellet formado, $3 \mathrm{~mL}$ da solução de lise de células (GentraPuregene ${ }^{*} \mathrm{Kit}$ ) contendo $0,5 \mathrm{mM}$ de desferoxamina/10 mM de D-penicilamina. Após completa dissolução do precipitado adicionou-se $105 \mu \mathrm{L}$ de SDS $10 \%$ e os tubos foram invertidos por 20 vezes. Em seguida foram adicionados $42 \mu \mathrm{L}$ de proteinase $\mathrm{K}(20 \mathrm{mg} / \mathrm{mL})$, inverteu-se os tubos 25 vezes e as amostras foram incubadas a $37^{\circ} \mathrm{C}$ por 1 hora. Foram então adicionados $12 \mu \mathrm{L}$ de RNAse $\mathrm{A}$ e as amostras foram incubadas por 2 horas à temperatura ambiente ao abrigo de luz. Posteriormente foram adicionados 1,5

$\mathrm{mL}$ da solução de precipitação de proteínas (GentraPuregene ${ }^{\bullet}$ Kit), agitou-se a amostra vigorosamente e centrifugou-se por 10 minutos a 2000 x g. Em seguida o sobrenadante foi vertido sobre $10 \mathrm{~mL}$ de isopropanol gelado para precipitação do DNA. O DNA precipitado foi então lavado com $10 \mathrm{~mL}$ de etanol 
$70 \%$ e mais uma vez centrifugado por 10 minutos a $2000 \times \mathrm{g}$, sendo essa etapa repetida por mais uma vez. Descartou-se o sobrenadante e o precipitado de DNA foi seco ao ar. Em seguida adicionou-se $400 \mu \mathrm{L}$ de desferroxamina 0,1 $\mathrm{mM}$, contendo $10 \mathrm{mM}$ de D-penicilamina e os tubos foram mantidos sob refrigeração por 1 noite.

Após completa solubilização do DNA, aferiu-se a concentração da amostra com leitura de absorbância em $260 \mathrm{~nm}$ e a pureza foi obtida pela razão das absorbâncias em 260 e 280 nm. As amostras de DNA foram congeladas a $-20{ }^{\circ} \mathrm{C}$ para posterior hidrólise imediatamente antes das análises.

\subsection{Quantificação de 8-oxodG e CEdG em amostras de DNA}

Para a reação de hidrólise enzimática, alíquotas contendo $80 \mu \mathrm{g}$ de DNA foram adicionadas a 3,8 $\mu \mathrm{L}$ de tampão Tris- $\mathrm{HCl} / \mathrm{MgCl}_{2} 200 \mathrm{mM}(\mathrm{pH} 7,4), 3,2$ unidades de DNAse $1(3,2 \mu \mathrm{L}), 5,3 \mu \mathrm{L}$ da solução contendo $75 \mathrm{fmol} / \mu \mathrm{L}$ do padrão $\left[{ }^{15} \mathrm{~N}_{5}\right]$ CEdG e $2 \mu \mathrm{L}$ da solução contendo $1000 \mathrm{fmol} / \mu \mathrm{L}$ do padrão $\left[{ }^{15} \mathrm{~N}_{5}\right] 8$-oxodG. As amostras foram incubadas a $37{ }^{\circ} \mathrm{C}$ por $1 \mathrm{~h}$. Após a incubação foram adicionadas 0,0016 unidade da enzima PDE1 $(3,2 \mu \mathrm{L})$ e 4,8 unidades da enzima fosfatase alcalina $(4 \mu \mathrm{L})$. As amostras foram novamente incubadas a $37^{\circ} \mathrm{C}$ por $1 \mathrm{~h}$ com agitação de $1000 \mathrm{rpm}$. Ao término da segunda hora, o volume final da incubação (100 $\mu \mathrm{L})$ foi centrifugado por $10 \mathrm{~min}$ a $9300 \mathrm{~g}$ e uma alíquota de $10 \mu \mathrm{L}$ do sobrenadante foi coletada para injeção de $5 \mu \mathrm{L}$ no sistema de HPLC-PDA, condição cromatográfica 5 , utilizado para quantificação dos desoxinucleosídeos normais ( $d C, d G$ e $d A)$. Alíquotas de $50 \mu \mathrm{L}$ foram injetadas paralelamente no sistema de HPLC-ESI-MS/MS (condição cromatográfica 7) para a quantificação das lesões. 
As análises foram realizadas em modo positivo $(E S I+,[M+H]+)$, utilizando os parâmetros otimizados: CUR, 15 psi; GS1, 45 psi; GS2, 50 psi; CAD, LOW; TEM, $650^{\circ} \mathrm{C}$; EP, $10 \mathrm{~V}$ e IS, $5500 \mathrm{~V}$. Foi utilizado o modo de monitoramento de reação múltipla (MRM) para deteç̧ão e quantificação das lesões, sendo utilizadas as seguintes fragmentações: $m / z 284[M+H]^{+} \rightarrow m / z$

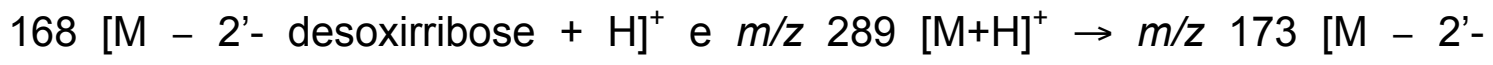
desoxirribose $+\mathrm{H}^{+}$para detecção de 8-oxodGuo e respectivo padrão interno $\left[{ }^{15} \mathrm{~N}_{5}\right] 8$-oxodGuo; $m / z 340[\mathrm{M}+\mathrm{H}]^{+} \rightarrow \mathrm{m} / \mathrm{z} 224\left[\mathrm{M}-2^{\prime} \text {-desoxirribose }+\mathrm{H}\right]^{+}$e $\mathrm{m} / \mathrm{z}$ $345[\mathrm{M}+\mathrm{H}]^{+} \rightarrow m / z 229\left[\mathrm{M}-2^{\prime}-\right.$ desoxirribose $+\mathrm{H}^{+}$para detecção de CEdG e respectivo padrão interno $\left[{ }^{15} \mathrm{~N}_{5}\right] \mathrm{CEdG}$.

\subsection{Quantificação de 5-metil-2'-desoxicitidina (5-metildC) e 5- hidroximetil-2'-desoxicitidina (5-hmdC) em DNA}

Alíquotas contendo $6 \mu \mathrm{g}$ de DNA em desferroxamina $(0,1 \mathrm{mM})$ foram adicionadas a 2,5 $\mu \mathrm{L}$ de tampão Tris- $\mathrm{HCl} / \mathrm{MgCl}_{2} 200 \mathrm{mM}(\mathrm{pH} 7,4)$ e 1,2 unidade de DNAse 1. As amostras foram incubadas a $37^{\circ} \mathrm{C}$ por $1 \mathrm{~h}$. Após a incubação foram adicionados 0,0005 unidade de fosfodiesterase 1 (PDE1) e 1,2 unidade de fosfatase alcalina. As amostras foram novamente incubadas a $37^{\circ} \mathrm{C}$ por $1 \mathrm{~h}$ com agitação de $1000 \mathrm{rpm}$. Ao término da segunda hora ao volume final da incubação (60 $\mu \mathrm{L})$ foram adicionados $140 \mu \mathrm{L}$ de acetonitrila. As amostras foram submetidas à vigorosa agitação por 20 segundos com posterior centrifugação a $9300 \mathrm{~g}$ por $10 \mathrm{~min}$. Após a centrifugação, alíquotas de $50 \mu \mathrm{L}$ foram injetadas no sistema HPLC-ESI-MS/MS (condição cromatográfica 8). As análises foram conduzidas com ionização por electrospray em modo positivo $\left(E S I^{+},[\mathrm{M}+\mathrm{H}]^{+}\right)$, 
utilizando os seguintes parâmetros otimizados: CUR, 15 psi; GS1, 45 psi; GS2, 50 psi; CAD, LOW; TEM, $650^{\circ} \mathrm{C}$; EP, $10 \mathrm{~V}$ e IS, $5500 \mathrm{~V}$. As fragmentações utilizadas no MRM encontram-se na figura a seguir. Curvas de quantificação foram feitas pela injeção de DNA de timo de bezerro contendo 2 - 1200 pmol de dC, 0,1-116 pmol de 5-mdC e 0,0005-0,010 pmol de 5-hmdC.
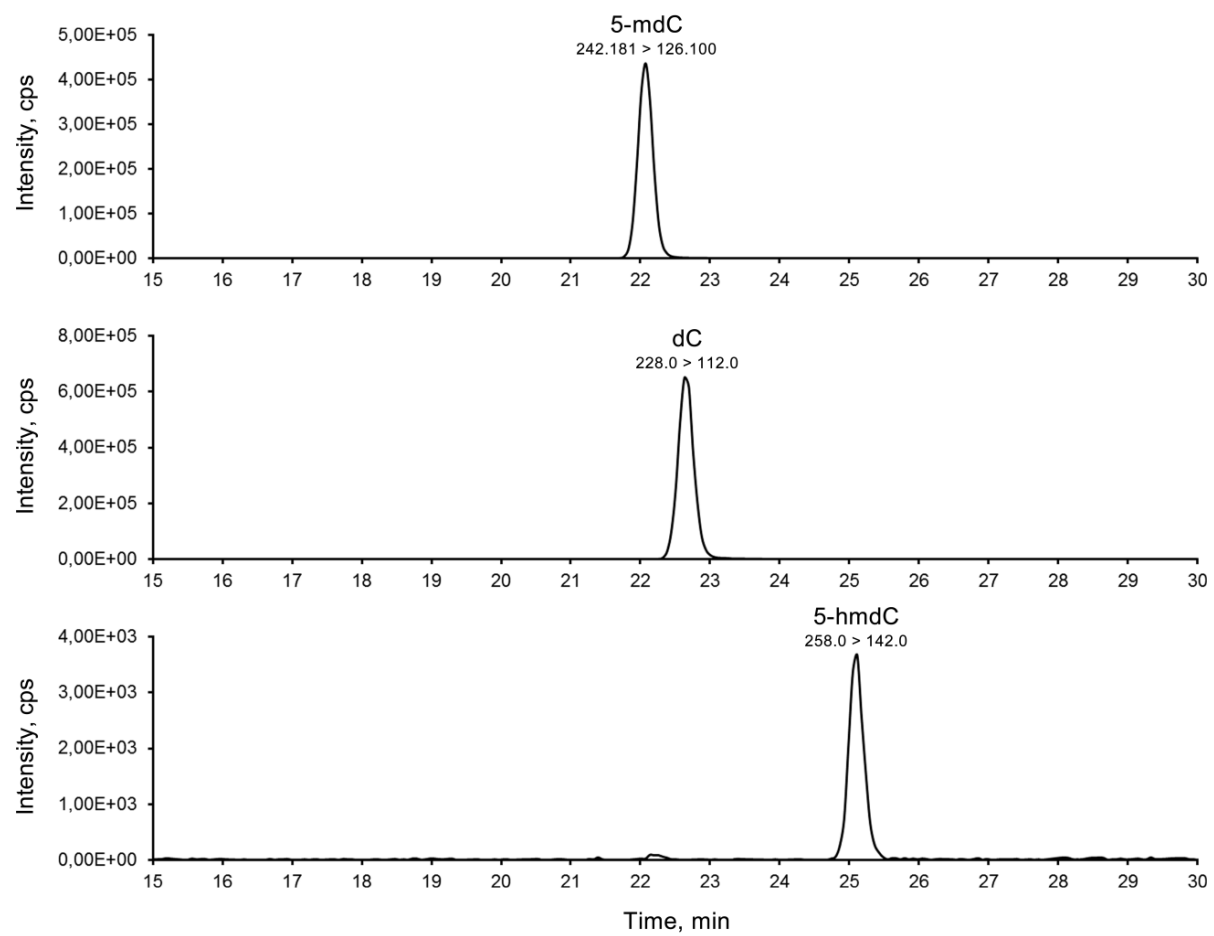

Figura 5 - Cromatogramas obtidos por HPLC-ESI-MS/MS de amostra de DNA para quantificação de dC, 5-mdC e 5-hmdC

\subsection{Exposição de ratos ao BPA na vigência e ausência de doença inflamatória sistêmica}

\subsubsection{Animais}

Para avaliação dos efeitos da exposição in vivo ao BPA foram utilizados ratos da linhagem Sprague-Dawley, machos, com peso de 200-250g, fornecidos pelo Biotério da Faculdade de Ciências Farmacêuticas e do Instituto de Química da Universidade de São Paulo. Os animais foram mantidos em 
condições normais de biotério até o início do experimento. Todos os procedimentos adotados estão em conformidade com as normas do Conselho Nacional de Controle de Experimentação Animal (CONCEA), como certificado pela Comissão de Ética no Uso de Animais da Faculdade de Ciências Farmacêuticas da Universidade de São Paulo (Protocolo CEUA/FCF/369 de 06/08/12).

\subsubsection{Indução de diabetes}

Para a indução do diabetes, os animais permaneceram em jejum por um período de 12 horas. Após esse período os mesmos foram anestesiados com Isoflurano 4\% (Isoforine ${ }^{\circledR}$ - Crystália, São Paulo) por via inalatória, utilizando-se um equipamento de anestesia inalatória (Morya $\left.{ }^{\circledR}\right)$. Uma solução recémpreparada de estreptozotocina (STZ-Sigma-Aldrich, St. Louis, MO) em solução salina (50 $\mathrm{mg} / \mathrm{mL})$ foi administrada por via intravenosa, através de punção da veia peniana, em volume correspondente à dose de $40 \mathrm{mg}$ de STZ por $\mathrm{Kg}$ de peso corpóreo. Os animais do grupo controle não diabético foram submetidos aos mesmos procedimentos, tendo recebido apenas o veículo por via intravenosa. A condição de diabetes foi confirmada após acompanhamento glicêmico 24, 48 e 72 horas após a administração de STZ. A glicemia foi mensurada no sangue coletado da veia caudal, utilizando-se glicosímetro Breeze $^{\mathrm{TM}}$ 2- (Bayer HealthCare, Mishawaka, USA), sendo que os animais que apresentaram glicemia igual ou superior a $250 \mathrm{mg} / \mathrm{dL}$ nas três medições foram considerados diabéticos e incluídos no estudo.

\subsubsection{Exposição ao BPA}

O esquema de exposição dos animais ao BPA compreendeu a administração diária de uma solução recém-preparada de BPA (50mg/Kg) 
diluído em óleo com $0,1 \%$ de DMSO por via intra-estomacal (gavagem), durante 4 semanas. Animais controles receberam óleo com $0,1 \%$ de DMSO pela mesma via e nas mesmas condições supracitadas. Os grupos estudados foram: Grupo Sadio com e sem BPA, ambos com 5 animais e Grupo Diabético com e sem BPA, ambos com 10 animais.

Os animais foram pesados diariamente para o ajuste da dose $\mathrm{e}$ concomitantemente a glicemia foi monitorada uma vez por semana durante todo o período de exposição.

\subsubsection{Eutanásia e obtenção de amostras}

Decorridas as 4 semanas de exposição, os animais foram anestesiados com uma solução de cloridrato de quetamina e xilazina 2:1 (100 $\mu \mathrm{L})$, por via intra-peritoneal. A cavidade peritoneal foi aberta e a artéria aorta abdominal foi exposta, a qual foi puncionada para coleta de sangue e consequente sacrifício por exsanguinação.

$\mathrm{O}$ sangue foi coletado em tubo heparinizado em quantidade de $8 \mathrm{~mL}$. O tubo foi então homogeneizado cuidadosamente e mantido em banho de gelo para posterior contagem total e diferencial de leucócitos. Em seguida o fígado e os rins foram coletados, lavados em PBS, pesados e armazenados em freezer $-80^{\circ} \mathrm{C}$ para posterior extração de DNA.

Para análise dos efeitos do BPA na medula óssea, células foram obtidas da cavidade femoral, imediatamente após os animais serem anestesiados e exsanguinados. As células da medula óssea foram obtidas pela lavagem da cavidade femoral com meio RPMI (Cultilab do Brasil ${ }^{\circledR}$ Campinas, SP), pH 7,4, estéril, suplementado com $10 \%$ de soro bovino fetal (Cultilab do Brasil® Campinas, SP) e com $100 \mathrm{Ul} / \mathrm{mL}$ de penicilina G sódica e $100 \mu \mathrm{g} / \mathrm{mL}$ de 
estreptomicina (Sigma ${ }^{\circledR}$ Chemical Company, USA), contendo 5\% de heparina sódica. A suspensão celular foi colocada em tubos Falcon, cuidadosamente homogeneizada e mantida em banho de gelo.

\subsubsection{Hemograma}

Para determinação do número total e diferencial de células circulantes, foi realizado o hemograma a partir de sangue total heparinizado. A dosagem de hemoglobina, a determinação do volume do hematócrito e a contagem global de hemácias e leucócitos foram feitas pelo analisador automático de células sanguíneas $A B C$ Vet (ABX DIAGNOSTICS).

As contagens diferenciais dos leucócitos foram feitas em extensões sanguíneas preparadas imediatamente após a coleta e coradas pelo corante de May-Grunwald-Giemsa. As lâminas foram analisadas em microscópio óptico comum, contando-se, no mínimo, 100 leucócitos por lâmina.

\subsubsection{Mielograma}

Para determinação dos efeitos da exposição ao BPA sobre o número total e diferencial de células da medula óssea, foi realizada contagem em lâminas coradas pelo método de May-Grünwald-Giemsa (ROSENFELD, 1947).

A contagem total de células foi realizada em hemocitômetro de Neubauer, após diluição das amostras da suspensão celular com meio de cultura Iscove's (Sigma-Aldrich ${ }^{\oplus}$, Chemical Company, USA).

A classificação das células da linhagem granulocítica foi baseada na relação núcleo-citoplasma, na afinidade tintorial do citoplasma, na presença ou não de granulações primária e secundária no citoplasma, no padrão de cromatina nuclear, na presença ou não de nucléolos, no diâmetro e segmentação ou não do nucléolo. Na série granulocítica, foram consideradas 
quatro etapas maturativas: (i) blastos envolvendo o hemocitoblasto e o mieloblasto; (ii) formas jovens englobando o promielócito e o mielócito; (iii) formas em anel correspondentes ao metamielócito e ao bastonete; (iv) segmentados envolvendo as formas segmentadas a partir de dois lóbulos nucleares (BORELLI, P et al. 1995).

Os precursores eritroides foram classificados em: (i) eritroblastos jovens envolvendo proeritroblastos e eritroblastos basófilos; (ii) eritroblastos policromáticos englobando todas as etapas em que as células apresentaram cromatina condensada e citoplasma policromático; (iii) eritroblastos ortocromáticos incluindo células com núcleo apresentando cromatina picnótica e citoplasma eosinofílico. Quando as células apresentaram assincronismo maturativo, prevaleceu aspecto da cromatina nuclear para identificação da etapa maturativa.

A identificação dos monoblastos e dos plasmoblastos seguiu os critérios morfológicos do padrão de cromatina nuclear e basofilia do citoplasma.

Promonócitos, monócitos e macrófagos foram reunidos em um grupo de células denominadas de monomacrofágicas.

As células da linhagem linfoide envolvendo prolinfócitos, linfócitos típicos ou atípicos foram agrupadas como linfócitos. As células da linhagem plasmocitária foram agrupadas como plasmócitos.

Todas as análises do hemograma e do mielograma foram realizadas com a colaboração do Prof. Dr. Ricardo Ambrósio Fock do Laboratório de Hematologia Experimental vinculado ao Departamento de Análises Clínicas e Toxicológicas da Faculdade de Ciências Farmacêuticas - USP. 


\subsection{Análise Estatística}

Os resultados aqui apresentados foram expressos como média \pm desvio padrão (S.D). Foram analisados estatisticamente pelo teste de Kruskal Wallis com pós teste de Dunn ou teste $t$ de student. Foi utilizado o programa de análise estatística GraphPad Prism versão 5.0 e os valores foram considerados estatisticamente significativos quando $p<0.05$. 
Gesultadas e Oiscussãa 


\section{Resultados Discussão}

\subsection{Síntese e caracterização das moléculas utilizadas neste estudo}

\subsubsection{Síntese de $\mathrm{BPANO}_{2}$}

A síntese de $\mathrm{BPANO}_{2}$ para ser utilizado nas incubações com as células foi realizada como descrito por Schrader et al., 2002. A solução final obtida foi injetada no sistema de HPLC-PDA. Os produtos resultantes podem ser observados na figura a seguir.

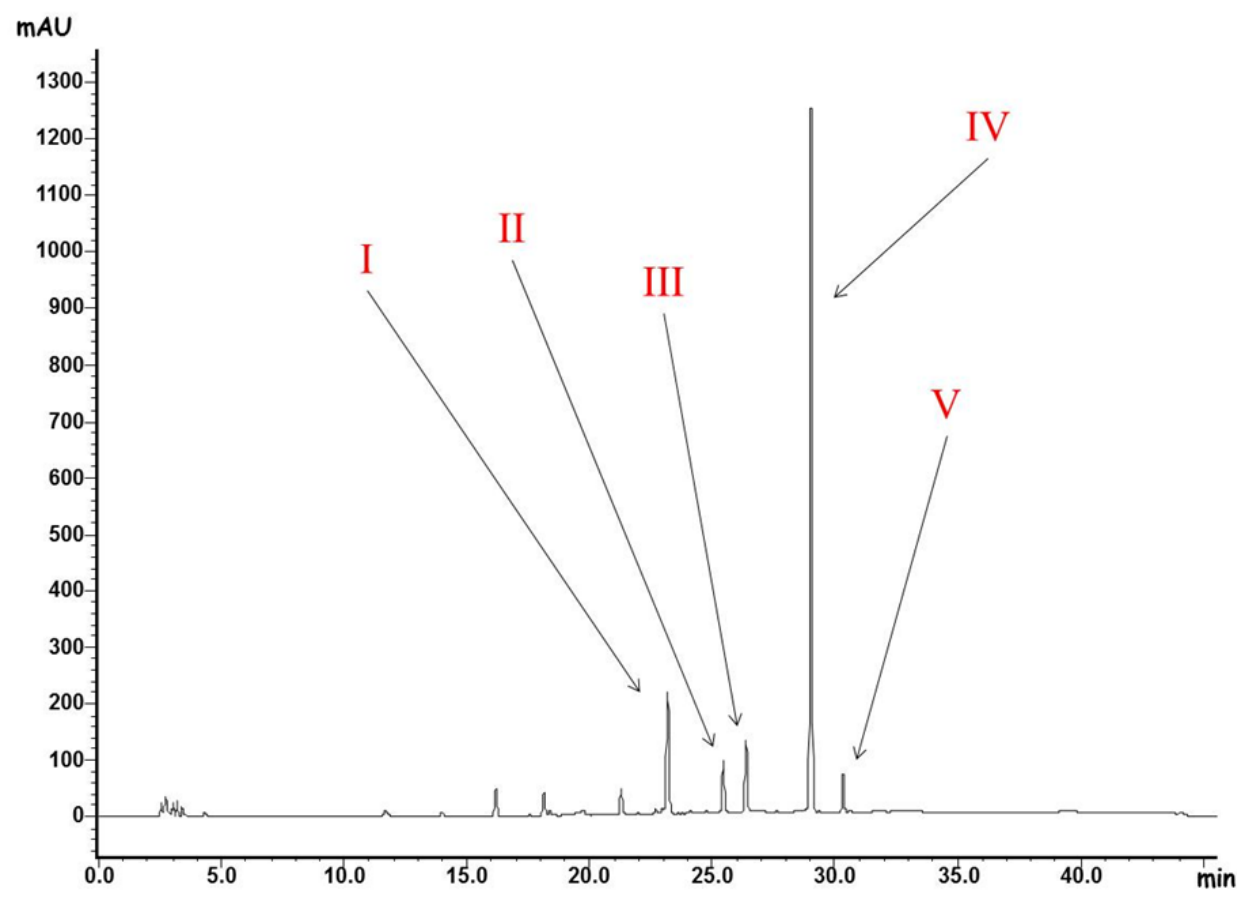

Figura 6 - Cromatograma obtido por HPLC - PDA $(\Lambda=260 \mathrm{~nm})$ da reação de BPA com nitrito de sódio em meio ácido. Foi utilizado o sistema cromatográfico 1.

Os picos de maior intensidade foram numerados de $\mathrm{I}$ a $\mathrm{V}$, coletados, liofilizados e submetidos a análise por ESI-MS/MS. Na figura a seguir estão apresentados os espectros de massas e de absorbância obtidos para os produtos IV e V, correspondendo, respectivamente, a $\mathrm{BPANO} \mathrm{N}_{2}$ e $\mathrm{BPA}\left(\mathrm{NO}_{2}\right)_{2}$. Os espectros de massas obtidos correspondem aos reportados por Schrader, 
Langlois et al. (2002) e Babu, Vellore et al. (2012). O pico III corresponde ao BPA que não reagiu, apresentando relação massa/carga $(\mathrm{m} / \mathrm{z}) 227$ e absorção máxima em $\lambda_{\max }=275 \mathrm{~nm}$, em modo negativo. Os produtos I e II não foram identificados. $\mathrm{O}$ produto $\mathrm{BPANO}_{2}$ foi purificado em quantidade suficiente (15 mg) para as incubações subsequentes com as células.

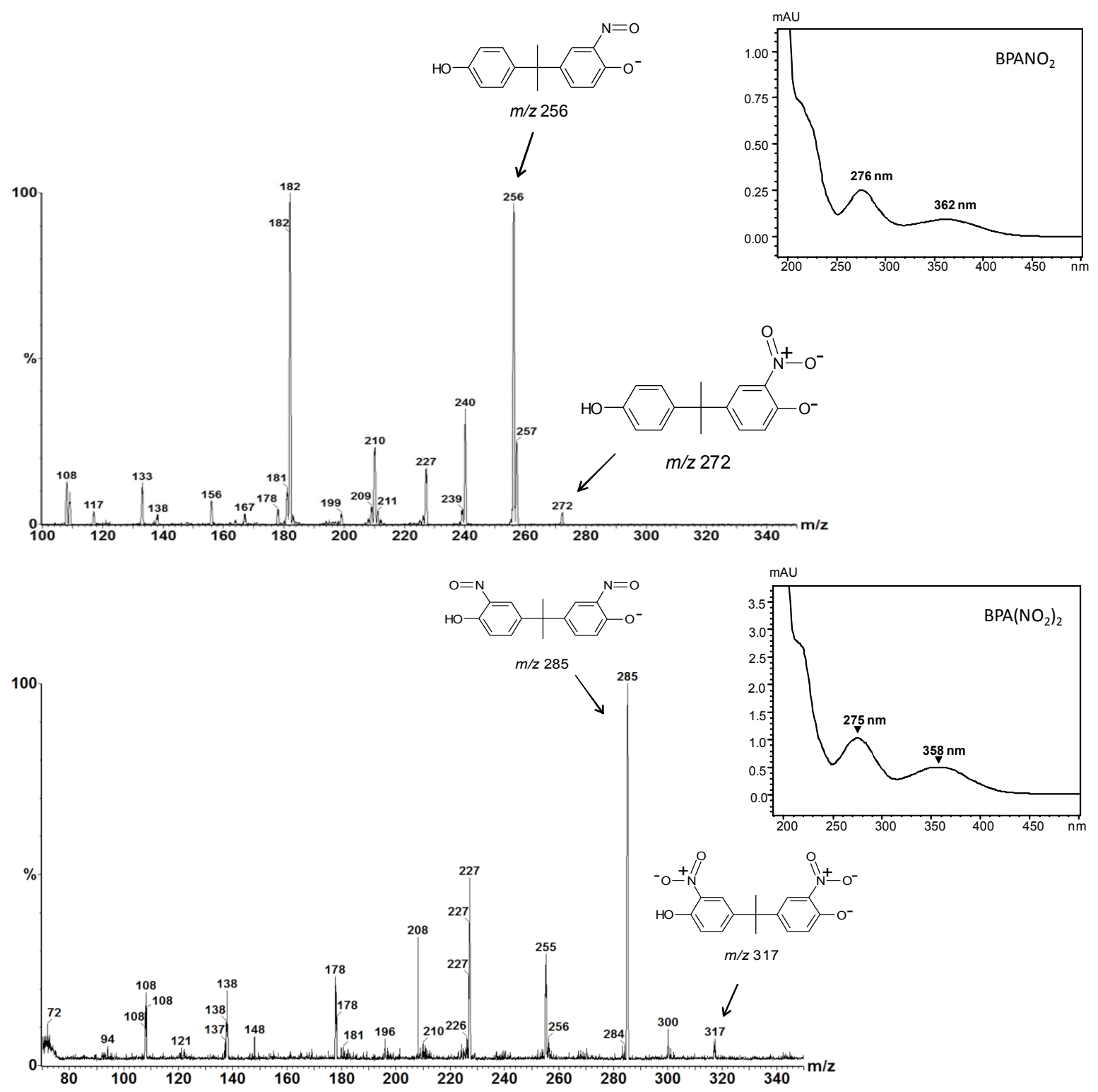

Figura 7 - Espectros de absorbância e espectros de massas no modo negativo (ESI-MS/MS, íons fragmentos de $\mathrm{m} / \mathrm{z} 272$ e $\mathrm{m} / \mathrm{z}$ 317) dos produtos IV e $\mathrm{V}$ da reação de BPA com nitrito de sódio, sendo indicados os produtos identificados. 


\subsubsection{Síntese de BPA-3,4-quinona (BPAQ)}

O produto formado após a reação de síntese de BPAQ pode ser observado na figura a seguir. O pico com maior intensidade foi coletado para identificação por espectrometria de massas, apresentando $\mathrm{m} / \mathrm{z} 241$ no modo negativo e os fragmentos indicados. O espectro de absorbância e espectro de massas obtidos correspondem ao produto BPAQ, como reportado por Qiu, Yang et al. (2004) e ATKINSON e ROY (1995).
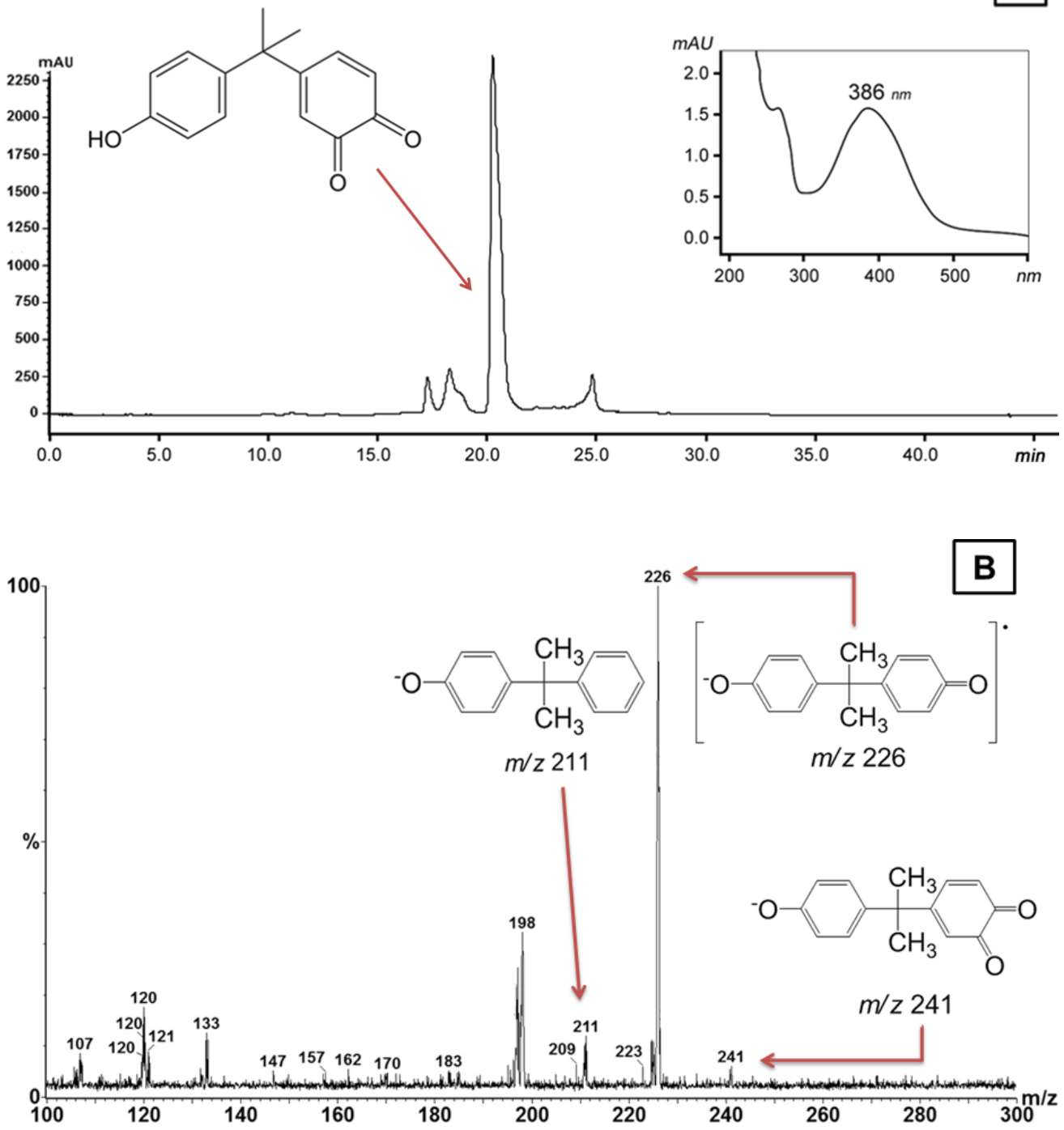

Figura 8 - (A) Cromatograma obtido por HPLC-PDA $(\lambda=385 \mathrm{~nm})$ da reação de BPA com sal de Fremy e espectro de absorbância do produto indicado (BPA-3,4-quinona). (B) Espectro de massas no modo negativo do produto BPA-3,4-quinona obtido (ESI-MS/MS, íons fragmentos de $\mathrm{m} / \mathrm{z} 241$ ). 


\subsubsection{Síntese do aduto de BPA-3,4-quinona com guanina (Gua)}

Para a síntese do aduto BPAQ-Gua foi utilizado o método descrito por Quu et al., 2004. Primeiramente foi realizada a síntese de BPA-3,4-quinona como descrito acima. O produto bruto obtido em acetona após oxidação do BPA com sal de Fremy, contendo BPAQ, foi então incubado com 2'desoxiguanosina (dGuo). Quando o produto BPAQ purificado foi incubado com dGuo, não foi possível observar a formação do aduto. Dessa forma, optou-se por fazer a reação do desoxinucleosídeo com a mistura de oxidação de BPA contendo BPAQ. Na figura a seguir estão apresentados o cromatograma com indicação do pico correspondente ao aduto (ausente nas incubações controles) e o espectro de massas obtido após purificação do produto indicado e análises por ESI-MS/MS. O mesmo procedimento foi realizado para as incubações com $\left[{ }^{15} \mathrm{~N}_{5}\right] \mathrm{dGuo}$, obtendo-se o respectivo aduto com a adição de 5 unidades de massa.

Como reportado por (Qiu, Yang et al. 2004), observou-se que o aduto obtido a partir da reação de dGuo com BPA oxidado não possui o açúcar em sua estrutura, tendo ocorrido a perda do açúcar durante a reação. A posição de ligação do BPA-3,4-quinona à guanina desestabiliza a ligação desta ao açúcar. 


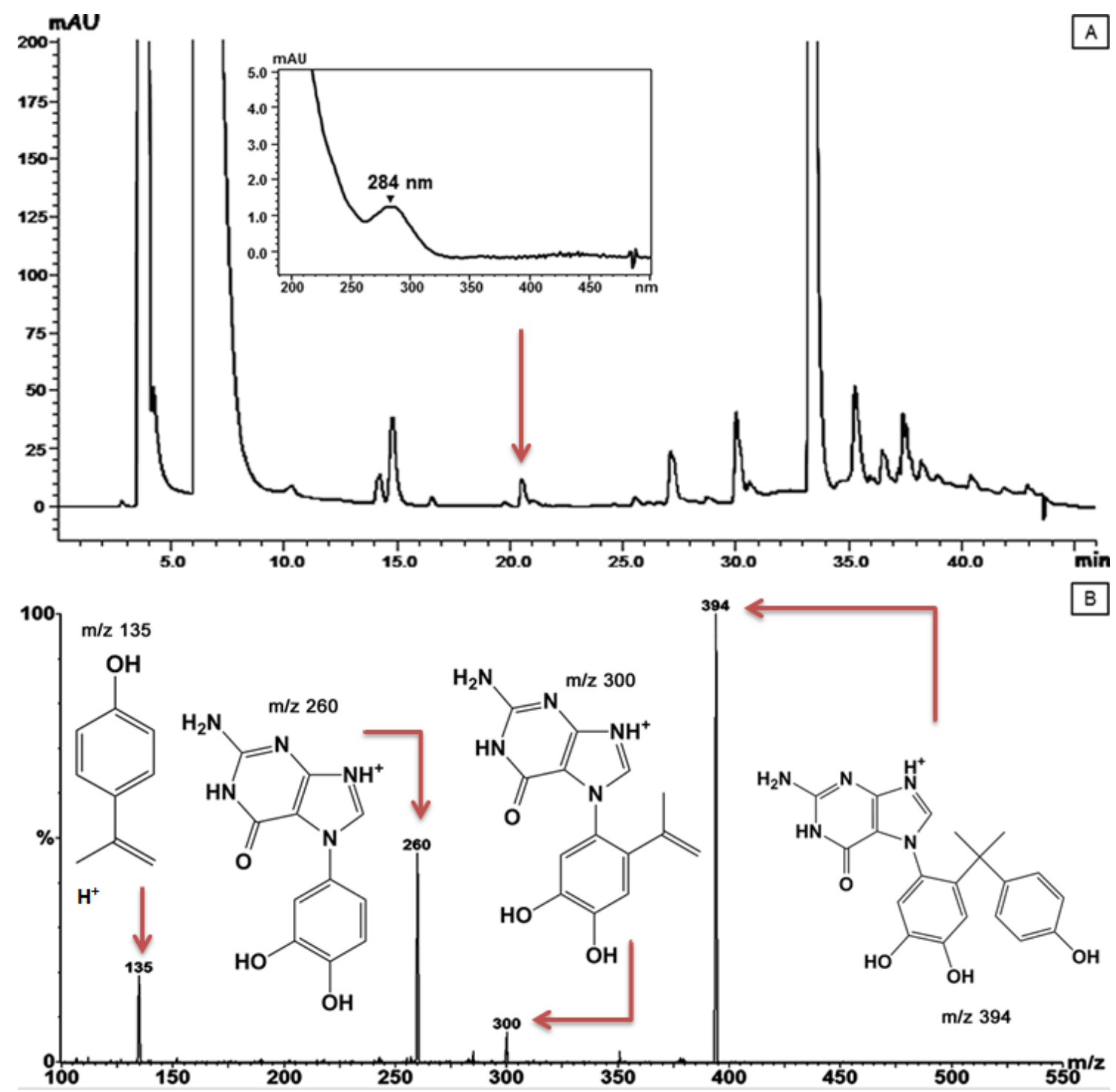

Figura 9 - (A) Cromatograma obtido por HPLC-DAD $(\lambda=275 \mathrm{~nm})$ da reação de BPA-3,4-quinona com dGuo, sendo indicado o aduto (BPA-Gua) e seu espectro de absorbância. O pico indicado não apareceu nas incubações controles; (B) Espectro de massas do produto isolado obtido no modo positivo (ESIMS/MS, íons fragmentos de $\mathrm{m} / \mathrm{z} 394$ )

Para quantificação do aduto BPA-Gua em amostras de DNA, meio de cultura das células e urina dos animais, foi necessário determinar o seu coeficiente de extinção molar $(\varepsilon)$, uma vez que esse dado não está disponível na literatura. A dificuldade para a determinação do $\varepsilon$ deve-se ao fato de não ser possível a síntese e purificação de grandes quantidades (pelo menos 5 mg) do aduto para adequada aferição da massa em balança analítica e obtenção de uma solução de concentração conhecida para leitura da absorbância. Assim, a 
determinação da concentração da solução do aduto purificado foi feita por meio de análises de espectros de ${ }^{1} \mathrm{H}$ RMN. Para obtenção dos espectros, foi necessário realizar purificações do aduto de modo a obter soluções em concentração suficiente para a obtenção dos sinais dos prótons. Como o rendimento da reação é baixo, diversas incubações e purificações foram realizadas. O produto final (aduto puro) foi liofilizado, solubilizado em DMSO- $d_{6}$ e alíquotas foram utilizadas para o preparo das soluções contendo 3(trimetilsilil)-1-propanosulfonato de sódio (DSS) como padrão interno para a determinação das concentrações. Dois tubos de RMN com concentrações diferentes de DSS e do aduto foram preparados como descrito abaixo:

Tubo 1: $\quad 0,2 \mathrm{mg}$ DSS $+400 \mu \mathrm{L}$ da solução do aduto $\left(\mathrm{V}_{\text {final }}=650 \mu \mathrm{L}\right)$ Tubo 2: $\quad 0,5 \mathrm{mg}$ DSS $+600 \mu \mathrm{L}$ da solução do aduto $\left(V_{\text {final }}=850 \mu \mathrm{L}\right)$

A partir da relação entre a média das áreas dos prótons do DSS e a média das áreas dos prótons do aduto em cada solução, foi possível determinar as concentrações do aduto nos diferentes tubos, uma vez que eram conhecidas as concentrações de DSS. Posteriormente, alíquotas de cada uma das amostras dos tubos de RMN foram diluídas com volumes apropriados das soluções para determinação de absorbância em pH 1 (tampão $\mathrm{HCl}-\mathrm{KCl}, 50$ mM), pH 7 (tampão fosfato de sódio, 50 mM) e pH 11 (tampão bicarbonatocarbonato, $50 \mathrm{mM}$ ). Após as medidas de absorbância das soluções em diferentes comprimentos de onda, os valores de $\varepsilon$ foram determinados pelas razões entre os valores de absorbância e concentração molar (Tabela 1). 


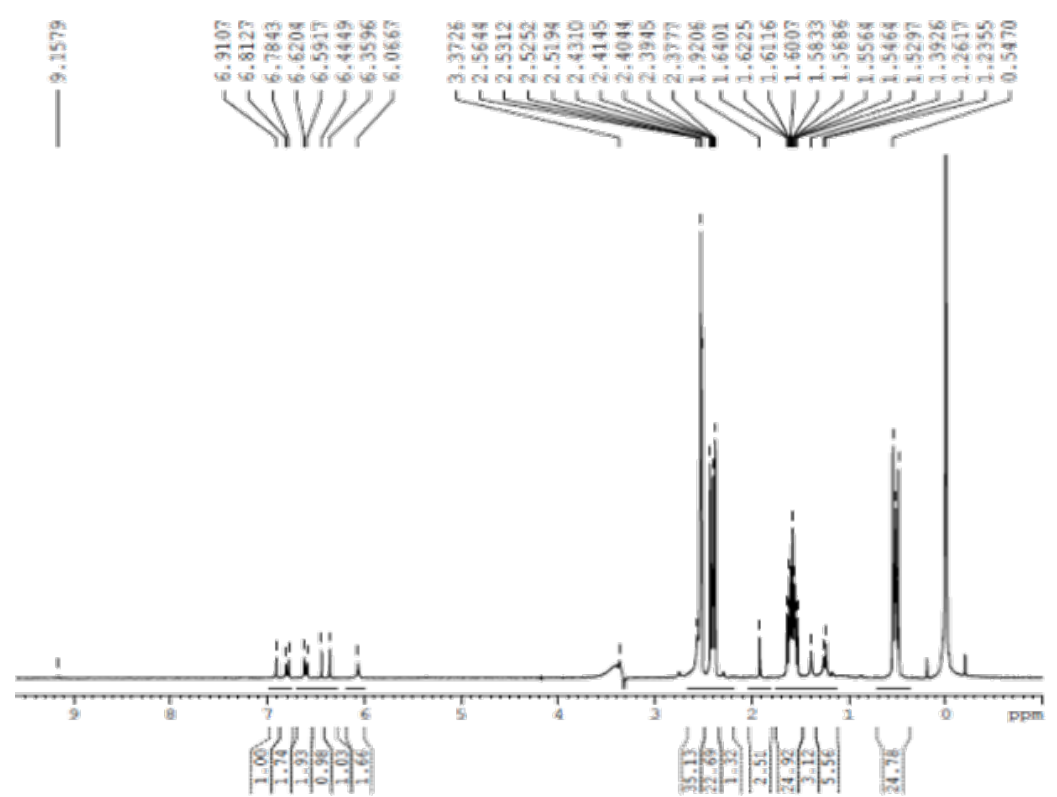

Figura 10 - Espectro de 1H RMN do aduto BPA-Gua. Espectros de Ressonância Magnética Nuclear obtidos do aduto BPA-Gua. Espectro de RMN com 0,2 mg de DSS em $650 \mu$ lde volume final.

Tabela 1 - Valores de coeficiente de extinção molar calculados para o aduto BPA-Gua.

\begin{tabular}{|l|l|}
\hline \multicolumn{2}{|c|}{ Aduto BPA-Gua } \\
\hline \multirow{2}{*}{$\mathrm{pH} \mathrm{1}$} & $\varepsilon_{248 \mathrm{~nm}}=39287 \mathrm{M}^{-1} \mathrm{~cm}^{-1}$ \\
\cline { 2 - 3 } & $\varepsilon_{278 \mathrm{~nm}}=36687 \mathrm{M}^{-1} \mathrm{~cm}^{-1}$ \\
\hline \multirow{2}{*}{$\mathrm{pH} \mathrm{7}$} & $\varepsilon_{242 \mathrm{~nm}}=49388 \mathrm{M}^{-1} \mathrm{~cm}^{-1}$ \\
\cline { 2 - 3 } & $\varepsilon_{286 \mathrm{~nm}}=45982 \mathrm{M}^{-1} \mathrm{~cm}^{-1}$ \\
\hline \multirow{2}{*}{$\mathrm{pH} \mathrm{11}$} & $\varepsilon_{244 \mathrm{~nm}}=51863 \mathrm{M}^{-1} \mathrm{~cm}^{-1}$ \\
\cline { 2 - 2 } & $\varepsilon_{286 \mathrm{~nm}}=24466 \mathrm{M}^{-1} \mathrm{~cm}^{-1}$ \\
\hline
\end{tabular}

Assim, as concentrações das soluções do aduto BPA-Gua e do padrão isotópico $\left[{ }^{15} \mathrm{~N}_{5}\right]$ BPA-Gua disponíveis no laboratório puderam ser determinadas. 


\subsection{Padronização do método de hidrólise do DNA para quantificação do aduto BPA-Guanina}

Para a quantificação do aduto BPA-Gua nas amostras de DNA foi necessário realizar alguns testes envolvendo a hidrólise neutra-térmica do DNA. Os testes foram baseados no trabalho de Loureiro e colaboradores (Loureiro, Zhang et al. 2009), substituindo-se o tampão cacodilato por tampão Tris- $\mathrm{HCl}(10 \mathrm{mM}, \mathrm{pH}$ 7,0). Entretanto, nessas condições verificou-se degradação do aduto. Após uma série de testes, foi possível chegar à condição de hidrólise que possibilitou a liberação do aduto BPA-Gua do DNA, sem degradação.

Na figura a seguir estão apresentados os cromatogramas obtidos a partir de uma amostra de DNA de timo de bezerro incubado in vitro com a mistura resultante da reação de oxidação de BPA com sal de Fremy. O DNA recuperado foi lavado duas vezes com etanol $70 \%$, solubilizado em água e congelado até a realização da hidrólise neutra-térmica. Para comparação, uma alíquota da mesma amostra de DNA foi submetida ao procedimento de hidrólise sem a incubação por $1 \mathrm{~h}$ a $70^{\circ} \mathrm{C}$, a fim de se verificar a possibilidade de o aduto ser liberado do DNA em condições brandas de manipulação. Como apresentado na Figura 11A, verificamos liberação do aduto BPA-Gua do DNA mesmo sem a incubação por $1 \mathrm{~h}$ a $70{ }^{\circ} \mathrm{C}$. A liberação é aumentada quando o aquecimento é realizado ao longo de $1 \mathrm{~h}$ (Figura 11B). 

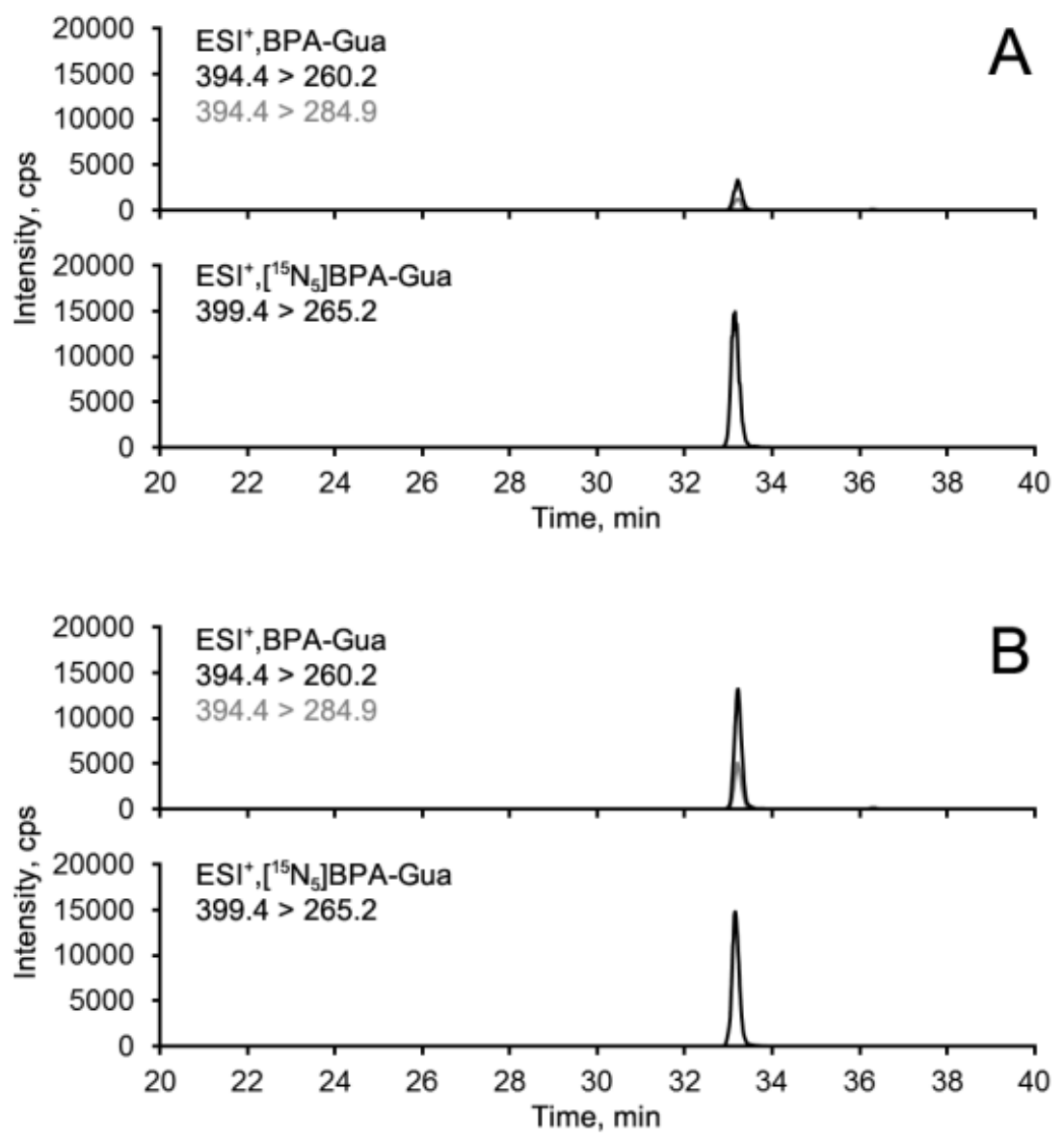

Figura 11 - Cromatogramas obtidos por HPLC-ESI-MS/MS de amostras de DNA de timo de bezerro incubado in vitro com BPA-3,4-quinona para análise do aduto BPA-Gua. A) DNA submetido ao procedimento de hidrólise neutra-térmica sem o período de $1 \mathrm{~h}$ de aquecimento a $70{ }^{\circ} \mathrm{C}$. B) DNA submetido ao procedimento completo de hidrólise neutra-térmica. 


\subsection{Efeitos citotóxicos, genotóxicos e epigenéticos em células HL-60 expostas a BPA e $\mathrm{BPANO}_{2}$}

Células HL-60 são derivadas de leucemia promielocítica humana, contem MPO e são utilizadas como modelos em diversos estudos nos quais a adição de $\mathrm{H}_{2} \mathrm{O}_{2}$ ativa MPO, que oxida substratos tais como fenol ou etoposídeo para os respectivos radicais, levando a dano oxidativo (TYURINA et al., 1995; GOLDMAN et al., 1999; BORISENKO et al., 2004; CUDDIHY et al., 2008). Assim, utilizou-se esse modelo para avaliação de danos que pudessem ser devidos à biotransformação de BPA por MPO.

\subsubsection{Avaliação da citotoxicidade em células HL-60}

As células HL-60 foram expostas por 2 h, 24 h ou 48 h a BPA (25 $\mu \mathrm{M}$, $100 \mu \mathrm{M}, 250 \mu \mathrm{M})$ ou $\mathrm{BPANO}_{2}(25 \mu \mathrm{M}, 100 \mu \mathrm{M}, 250 \mu \mathrm{M})$, na presença e ausência de $\mathrm{H}_{2} \mathrm{O}_{2}\left(40 \mathrm{nmol} / 5 \times 10^{4}\right.$ células $)$. A citotoxicidade foi avaliada pela análise da permeabilidade da membrana plasmática ao iodeto de propídeo, por citometria de fluxo. Nas figuras a seguir são apresentados os dados obtidos para as incubações com BPA e $\mathrm{BPANO}_{2}$, respectivamente.

Foi observado aumento da permeabilidade da membrana das células após $24 \mathrm{~h}$ de incubação com BPA $(25 \mu \mathrm{M}, 100 \mu \mathrm{M}, 250 \mu \mathrm{M})$ ou $\mathrm{BPANO}_{2}(250$ $\mu \mathrm{M})$, na presença ou ausência de $\mathrm{H}_{2} \mathrm{O}_{2}$. Observou-se, ainda, aumento crescente da permeabilidade da membrana plasmática após 48 h de incubação das células com $250 \mu \mathrm{M}$ de BPA. Entretanto, nas concentrações de $25 \mu \mathrm{M}$ e $100 \mu \mathrm{M}$ de BPA não houve aumento adicional da permeabilidade da membrana plasmática após o período de $48 \mathrm{~h}$. Nas incubações com $\mathrm{BPANO}_{2}$ não foi observada perda da viabilidade celular após $48 \mathrm{~h}$. 
Uma vez que as células HL-60 apresentaram resistência à perda de viabilidade com o passar do tempo de incubação, avaliou-se o consumo de BPA ao longo do tempo. Observa-se, que após um período inicial (12 h) de absorção do BPA pelas células, o consumo atingiu um platô. Após $84 \mathrm{~h}$ de incubação com $250 \mu \mathrm{M}$ de BPA, apenas $15 \%$ da quantidade disponível inicialmente havia sido absorvida pelas células. As análises do meio de cultura foram feitas por HPLC-DAD, não tendo sido possível a detecção de produtos de biotransformação do BPA. 

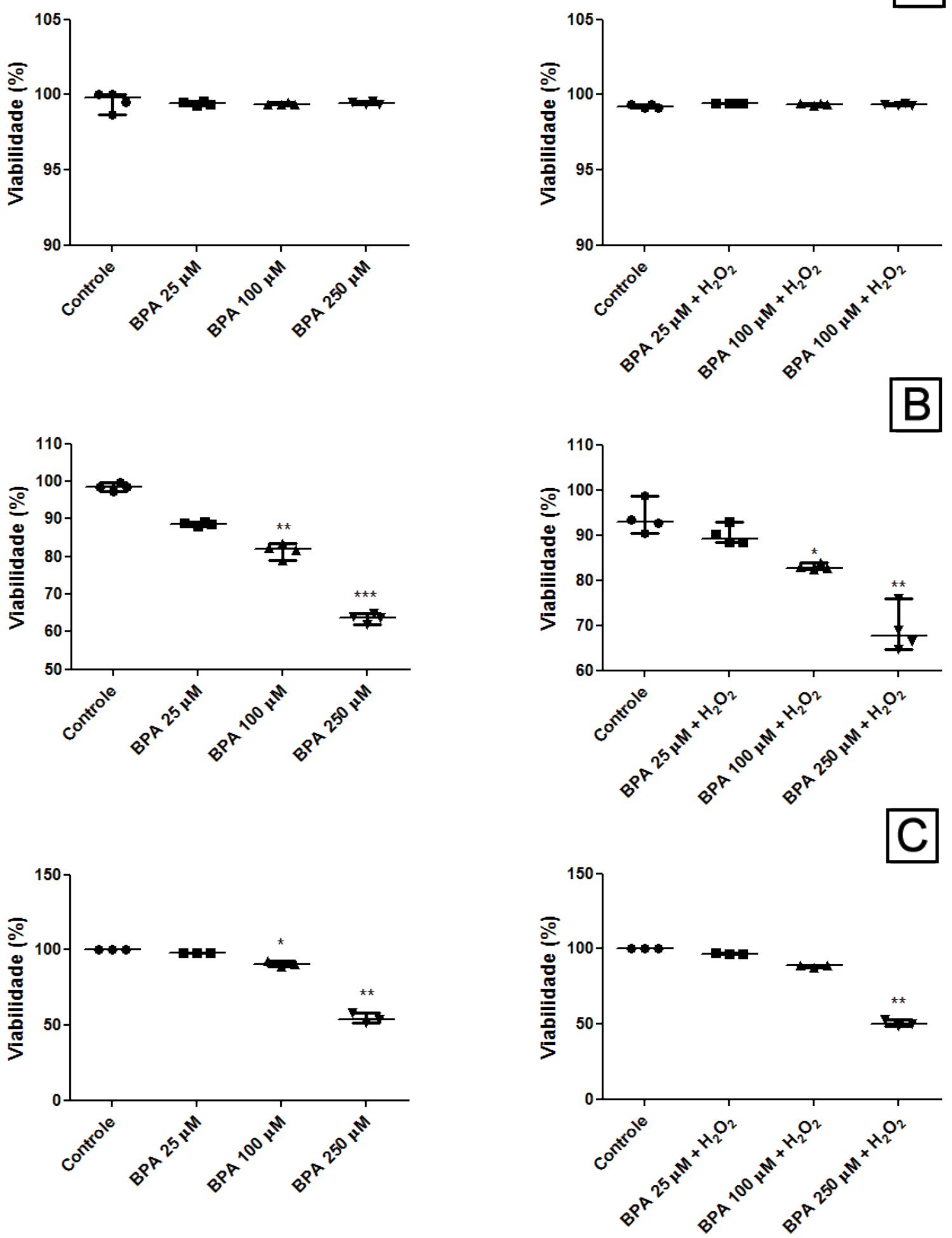

Figura 12 - Viabilidade das células HL-60 avaliada por citometria de fluxo após: (A) 2 h de incubação com as concentrações indicadas de BPA, com e sem $\mathrm{H}_{2} \mathrm{O}_{2}\left(40 \mathrm{nmol} / 5 \times 10^{4}\right.$ células $) ;(B) 24 \mathrm{~h}$ de incubação com as concentrações indicadas de BPA, com e sem $\mathrm{H}_{2} \mathrm{O}_{2}\left(40 \mathrm{nmol} / 5 \times 10^{4}\right.$ células); (C) $48 \mathrm{~h}$ de incubação com as concentrações indicadas de BPA, com e sem $\mathrm{H}_{2} \mathrm{O}_{2}\left(40 \mathrm{nmol} / 5 \times 10^{4}\right.$ células). média \pm desvio padrão Kruskal Wallis com pós teste de Dunn, diferenças em relação ao respectivo controle. ${ }^{*} \mathrm{P}<0.05 ;{ }^{* *} \mathrm{P}<0.01 ;{ }^{* * *} \mathrm{P}<0.001$. 

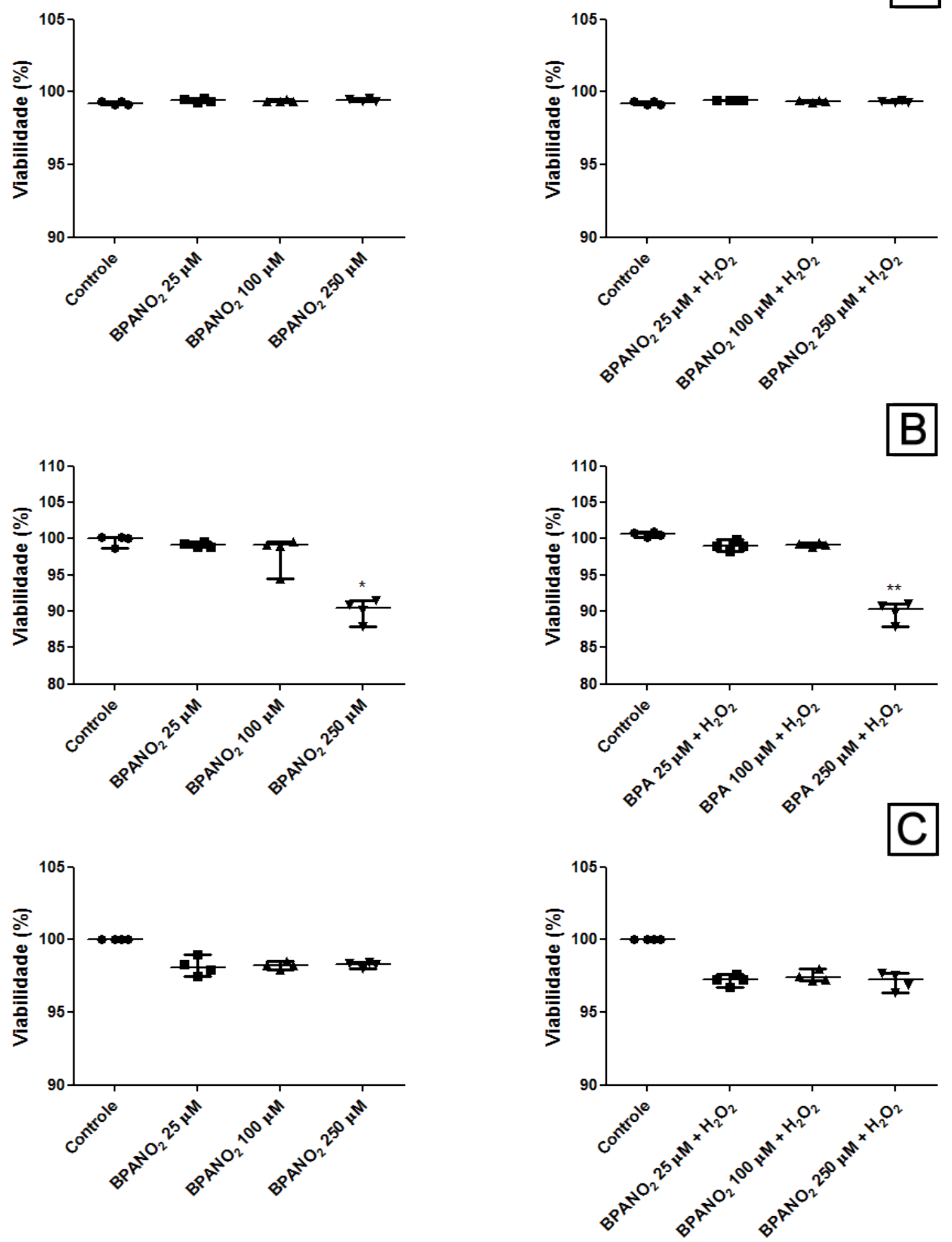

Figura 13 - Viabilidade das células HL-60 avaliada por citometria de fluxo após: (A) 2 h de incubação com as concentrações indicadas de $\mathrm{BPANO}_{2}$, com e sem $\mathrm{H}_{2} \mathrm{O}_{2}\left(40 \mathrm{nmol} / 5 \times 10^{4}\right.$ células $)$; (B) $24 \mathrm{~h}$ de incubação com as concentrações indicadas de $\mathrm{BPANO}_{2}$, com e sem $\mathrm{H}_{2} \mathrm{O}_{2}\left(40 \mathrm{nmol} / 5 \times 10^{4}\right.$ células). (C) $48 \mathrm{~h}$ de incubação com as concentrações indicadas de $\mathrm{BPANO}_{2}$, com e sem $\mathrm{H}_{2} \mathrm{O}_{2}\left(40 \mathrm{nmol} / 5 \times 10^{4}\right.$ células). $N=4$, média \pm desvio padrão, Kruskal Wallis com pós teste de Dunn, diferenças em relação ao respectivo controle. ${ }^{*} \mathrm{P}<0.05 ;{ }^{*} \mathrm{P}<0.01$. 
$\mathbf{A}$

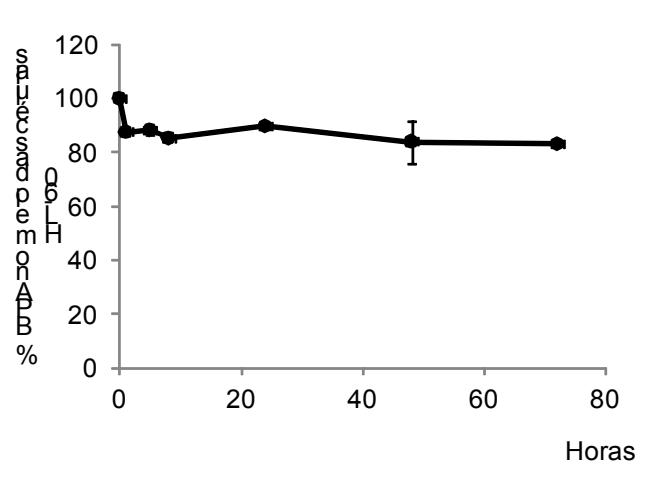

B

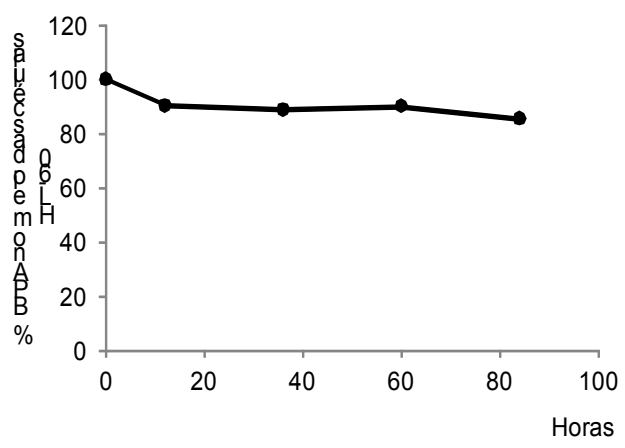

Figura 14 - Consumo de BPA pelas células HL-60. As células foram cultivadas na densidade de $2,4 \times 10^{6}$ (A) ou $1 \times 10^{7}$ (B) células por poço e expostas a $250 \mu \mathrm{M}$ de BPA. Alíquotas do meio de cultura foram retiradas nos períodos indicados para quantificação de BPA por HPLC-DAD $(\lambda=277 \mathrm{~nm})$.

Considerando-se a fração de BPA absorvida, o número de células e o volume de meio de cultura nas incubações, estimou-se um nível intracelular médio de BPA na ordem de poucos pg/célula. É reportado que a absorção de BPA pelo trato gastrointestinal humano é rápida e a recuperação na urina após $24 \mathrm{~h}$ é quase completa na forma conjugada com glicuronídeo (meia-vida de excreção urinária de 5,4 h) (Volkel, Colnot et al. 2002). A rápida e quase completa excreção de BPA na urina sugerem que, ao contrário do que ocorre no trato gastrointestinal e fígado, BPA seja pouco absorvido pelas células de outros tecidos. Concentrações de BPA no soro e urina humanos estão na faixa de 0,2 a $20 \mu \mathrm{g} / \mathrm{L}$ (Calafat, Kuklenyik et al. 2005; Welshons, Nagel et al. 2006; Lang, Galloway et al. 2008), sendo muito inferiores às utilizadas no meio de cultura de células nos estudos in vitro. Entretanto, nos estudos in vitro observam-se efeitos decorrentes das concentrações intracelulares atingidas no intervalo de poucas horas, enquanto que in vivo a exposição ocorre de forma 
crônica e, dependendo da velocidade de biotransformação e excreção celular da substância, pode haver, ao longo do tempo, incremento das concentrações intracelulares para os níveis correspondentes aos dos estudos in vitro. A concentração de $20 \mu \mathrm{g} / \mathrm{L}$ (ou $20 \mathrm{pg} / \mu \mathrm{L}$ ) de BPA no soro humano permite que células mais permeáveis estejam sujeitas a níveis de BPA na ordem de poucos picogramas ao longo do tempo.

Com o intuito de verificar se BPA e $\mathrm{BPANO}_{2}$ interferem na cadeia de transporte de elétrons mitocondrial, alterando a atividade da succinato desidrogenase e, assim, levando à perda de viabilidade celular, as células foram expostas por $24 \mathrm{~h}$ e em seguida submetidas ao ensaio do XTT. Na figura a seguir são apresentados os dados obtidos, sendo observada inibição da atividade desidrogenase da cadeia respiratória nas incubações com BPA por $24 \mathrm{~h}$, na ausência e presença de $\mathrm{H}_{2} \mathrm{O}_{2}$, o mesmo não ocorrendo nas incubações com $\mathrm{BPANO}_{2}$. A perda da atividade respiratória mitocondrial observada nas incubações com BPA parece preceder a perda da integridade da membrana plasmática, podendo haver a participação de ROS/RNS no processo. 

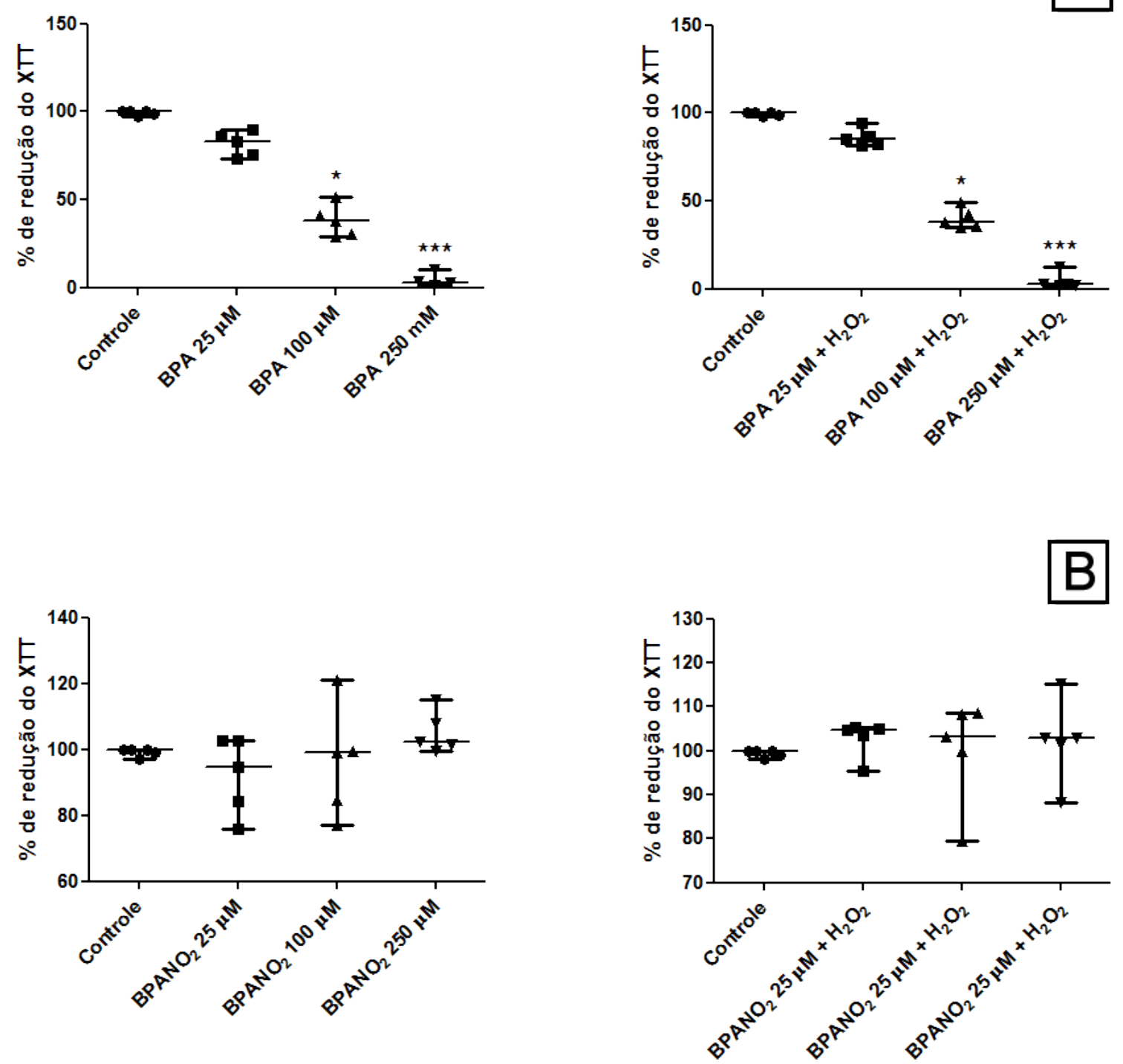

Figura 15 - Viabilidade das células HL-60 avaliada pelo ensaio do XTT após $24 \mathrm{~h}$ de incubação com as concentrações indicadas de BPA e $\mathrm{BPANO}_{2}$, com e sem $\mathrm{H}_{2} \mathrm{O}_{2}\left(40 \mathrm{nmol} / 5 \times 10^{4}\right.$ células). , média \pm desvio padrão, , Kruskal Wallis com pós teste de Dunn, diferenças em relação ao respectivo controle. ${ }^{*} \mathrm{P}<0.05$; ${ }^{* * *} \mathrm{P}<0.001$.

A literatura traz informações sobre a indução de estresse oxidativo por BPA (Hassan, Elobeid et al. 2012; Hulak, Gazo et al. 2013; Wu, Liu et al. 2013). Dessa forma, a avaliação da geração intracelular de ROS/RNS é necessária para a compreensão dos efeitos tóxicos desse xenobiótico.

A indução de estresse oxidativo foi monitorada quantitativamente por análise de fluorescência do produto 2',7'-diclorofluoresceína (DCF) resultante 
da oxidação de 2',7'-diclorodihidrofluoresceína (DCFH) por radicais livres gerados intracelularmente, como $\mathrm{RO}_{2}{ }^{\circ}, \mathrm{RO}^{\circ}, \mathrm{NO}_{2}{ }^{\circ}, \mathrm{CO}_{3}{ }^{-}$e $\mathrm{HO} O^{\circ}$ (HELD, P.; 2010). Os dados obtidos estão apresentados na figura 16. Observa-se que a geração de ROS/RNS é um evento precoce nas incubações de células HL-60 com BPA e BPANO ${ }_{2}$. No caso de BPA, a indução foi observada após $1 \mathrm{~h}$ de incubação com $100 \mu \mathrm{M}$ e $250 \mu \mathrm{M}$, não havendo efeito da adição de $\mathrm{H}_{2} \mathrm{O}_{2}$. Quanto ao $\mathrm{BPANO}_{2}$, a indução de ROS/RNS ocorreu em todas as concentrações testadas, principalmente na ausência de $\mathrm{H}_{2} \mathrm{O}_{2}$. Como apresentado nas figuras 12 e 13, nesse período de incubação não foi observado aumento da permeabilidade da membrana plasmática das células expostas a essas concentrações de BPA e BPANO ${ }_{2}$. 

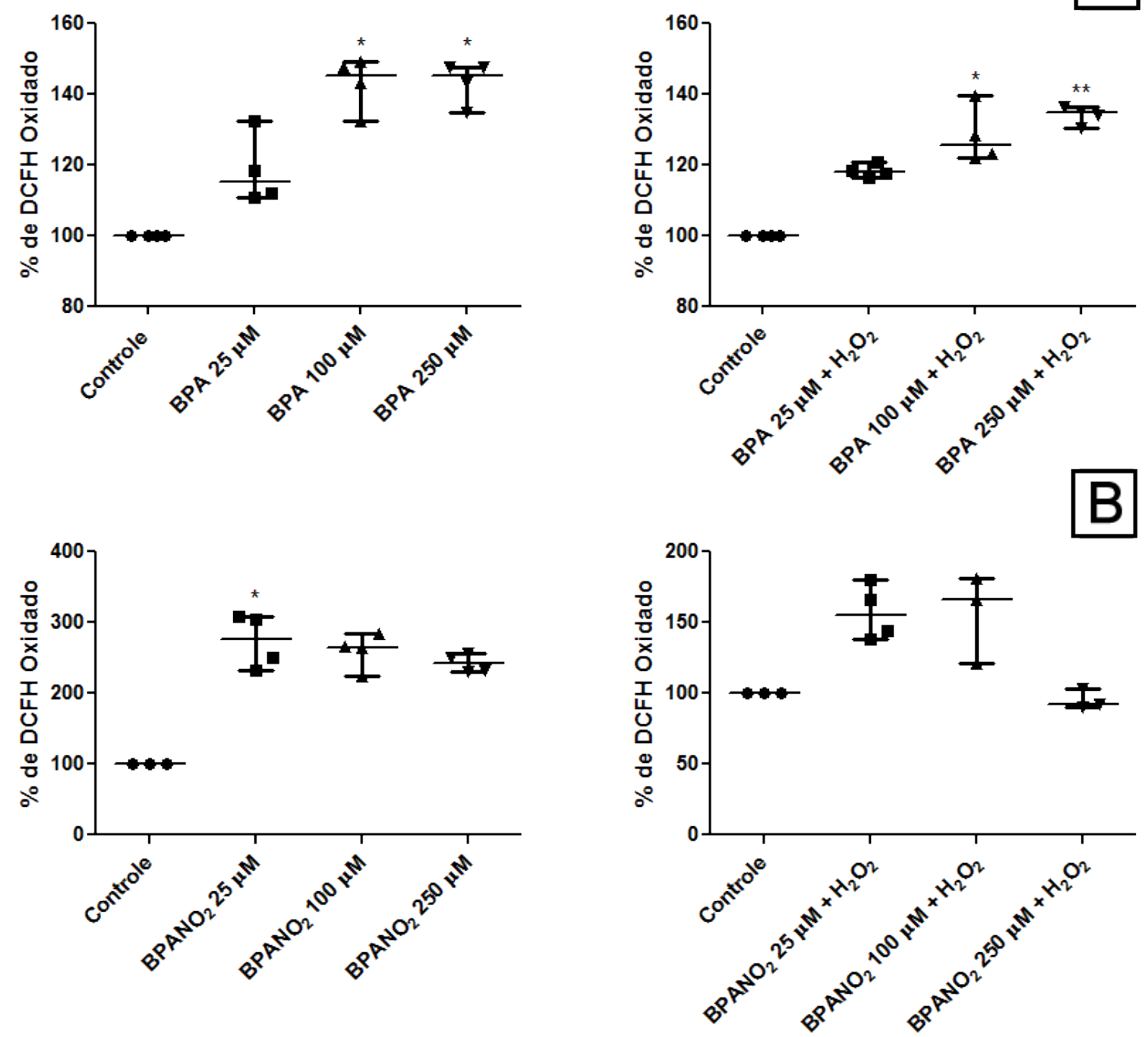

Figura 16 - Fluorescência relativa (\%) do produto DCF nas células HL-60 após $1 \mathrm{~h}$ de incubação (A) com as concentrações indicadas de BPA com e sem $\mathrm{H}_{2} \mathrm{O}_{2}\left(40 \mathrm{nmol} / 5 \times 10^{4}\right.$ células). (B) com as concentrações indicadas de $\mathrm{BPANO}_{2}$ com e sem $\mathrm{H}_{2} \mathrm{O}_{2}\left(40 \mathrm{nmol} / 5 \times 10^{4}\right.$ células $) . \mathrm{N}=4$, média \pm desvio padrão, Kruskal Wallis com pós-teste de Dunn, diferenças em relação ao respectivo controle. ${ }^{*} P<0.05$; ${ }^{*} P<0.01$.

Sabe-se que vias de redução de grupos nitro levam à formação de diversos intermediários radicalares e não radicalares. No processo de biotransformação pode haver também a geração de ROS a partir da redução de $\mathrm{O}_{2}$ pelos radicais intermediários (Toyoizumi, Deguchi et al. 2008). Assim, era esperada indução de ROS/RNS nas células expostas a $\mathrm{BPANO}_{2}$. 
Entretanto, essas alterações iniciais não levaram à perda da viabilidade celular após 24 h de incubação, ao contrário do que ocorreu com o BPA.

BPA, ao longo do período de $24 \mathrm{~h}$ de incubação, pode levar a alterações mitocondriais que agravam o estado de estresse oxidativo das células, levando à perda de viabilidade. A possibilidade de formação de BPA-3,4-quinona intracelularmente pode também aumentar a geração de ROS, via formação do radical semiquinona e entrada da molécula em um ciclo redox. Adicionalmente, pode haver a indução de óxido nítrico sintase (NOS), com síntese de grandes quantidades $(\mu \mathrm{M})$ de $\mathrm{NO}$ que, na presença de $\mathrm{O}_{2}{ }^{-}$, leva à formação de peroxinitrito e radicais livres reativos resultantes de sua clivagem $\left(\mathrm{NO}_{2} \cdot, \mathrm{OH}\right.$, $\mathrm{CO}_{3}^{-}$), que contribuem para os danos celulares (Oh and Lim 2008; Gu, Nakamura et al. 2010).

Para avaliar a possibilidade de aumento da geração de $\cdot N O$, foi realizada a quantificação de $\mathrm{NO}_{2}$ no meio de cultura das células $\mathrm{HL}-60$ expostas ao BPA nas concentrações de $25 \mu \mathrm{M}, 100 \mu \mathrm{M}$ ou $250 \mu \mathrm{M}$, na presença ou ausência de $\mathrm{H}_{2} \mathrm{O}_{2}$, utilizando a reação de Griess. Os dados obtidos estão apresentados na figura 17.

Observa-se que $\mathrm{H}_{2} \mathrm{O}_{2}$ estimulou a geração de nitrito pelas células $\mathrm{HL}-60$ (2 h e 24 h). Entretanto, na presença de BPA $+\mathrm{H}_{2} \mathrm{O}_{2}$ a geração de nitrito foi diminuída. Por outro lado, na ausência de $\mathrm{H}_{2} \mathrm{O}_{2}$ observou-se a indução de geração de nitrito por BPA. Na presença de $\mathrm{H}_{2} \mathrm{O}_{2}$ é possível que BPA seja alvo para o ataque dos radicais livres gerados, incluindo $\mathrm{NO}_{2}$, o que poderia contribuir para a queda da geração de nitrito (Kim and Jeong 2003; Terasaka, Kadoma et al. 2005; Moon, Kim et al. 2012). Entretanto, não foram detectados produtos de biotransformação do BPA no meio de cultura das células. 
$\mathrm{Na}$ figura 18 são apresentados os dados de atividade de mieloperoxidase (MPO) das células HL-60 expostas ao BPA, mostrando que as incubações pelos períodos de $2 \mathrm{~h}$ e 24 h não alteraram a atividade da enzima.
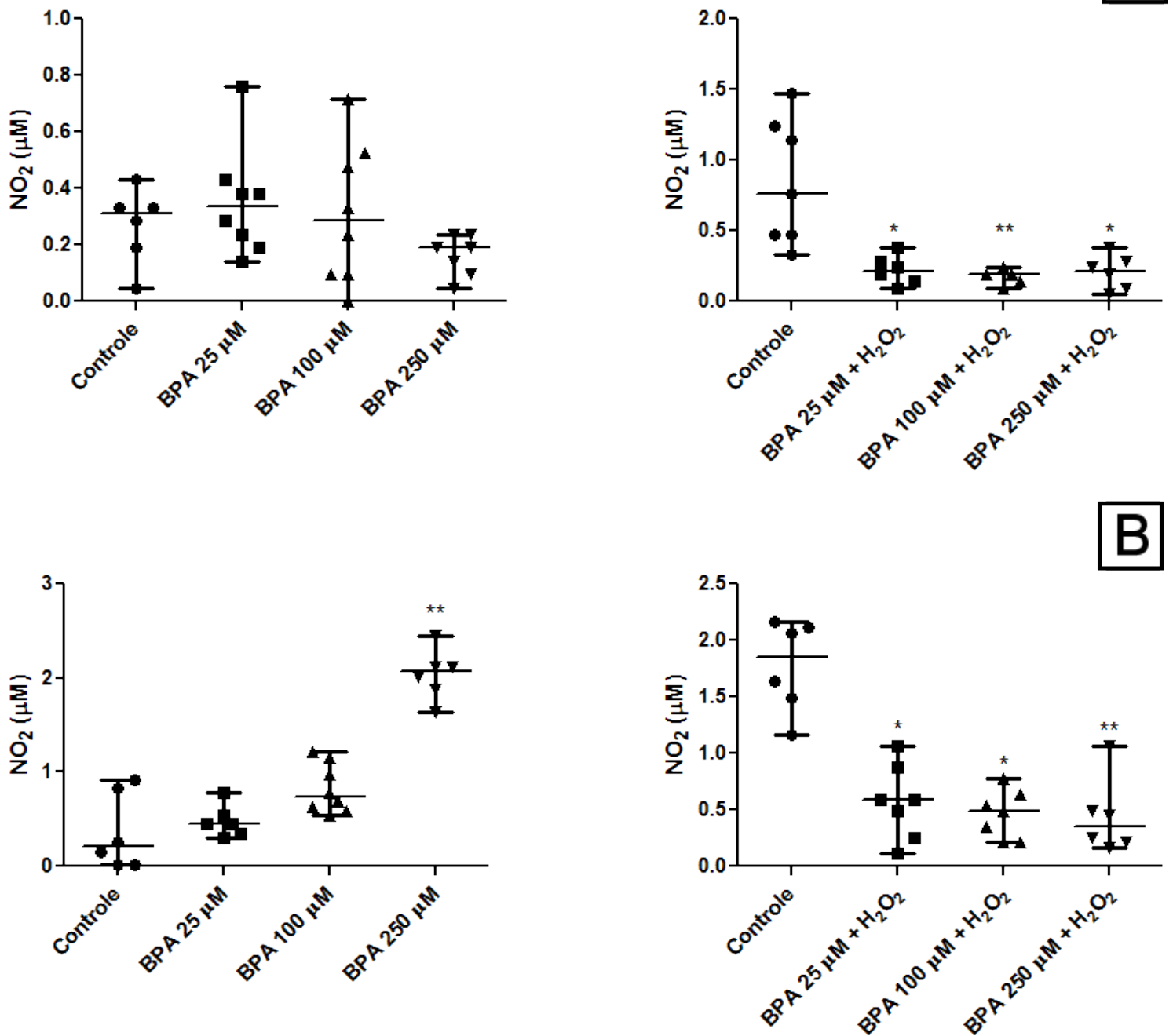

Figura 17 - Geração de nitrito pelas células HL-60 após: (A) 2 h de incubação com as concentrações indicadas de $\mathrm{BPA}$, sem e com $\mathrm{H}_{2} \mathrm{O}_{2}$ (40 nmol/5 $\times 10^{4}$ células); (B) $24 \mathrm{~h}$ de incubação com as concentrações indicadas de BPA, sem e com $\mathrm{H}_{2} \mathrm{O}_{2}\left(40 \mathrm{nmol} / 5 \times 10^{4}\right.$ células $)$, média \pm desvio padrão, Kruskal Wallis com pós teste de Dunn, diferenças em relação ao respectivo controle. ${ }^{*} \mathrm{P}<0.05 ;{ }^{* *} \mathrm{P}<0.01$. 

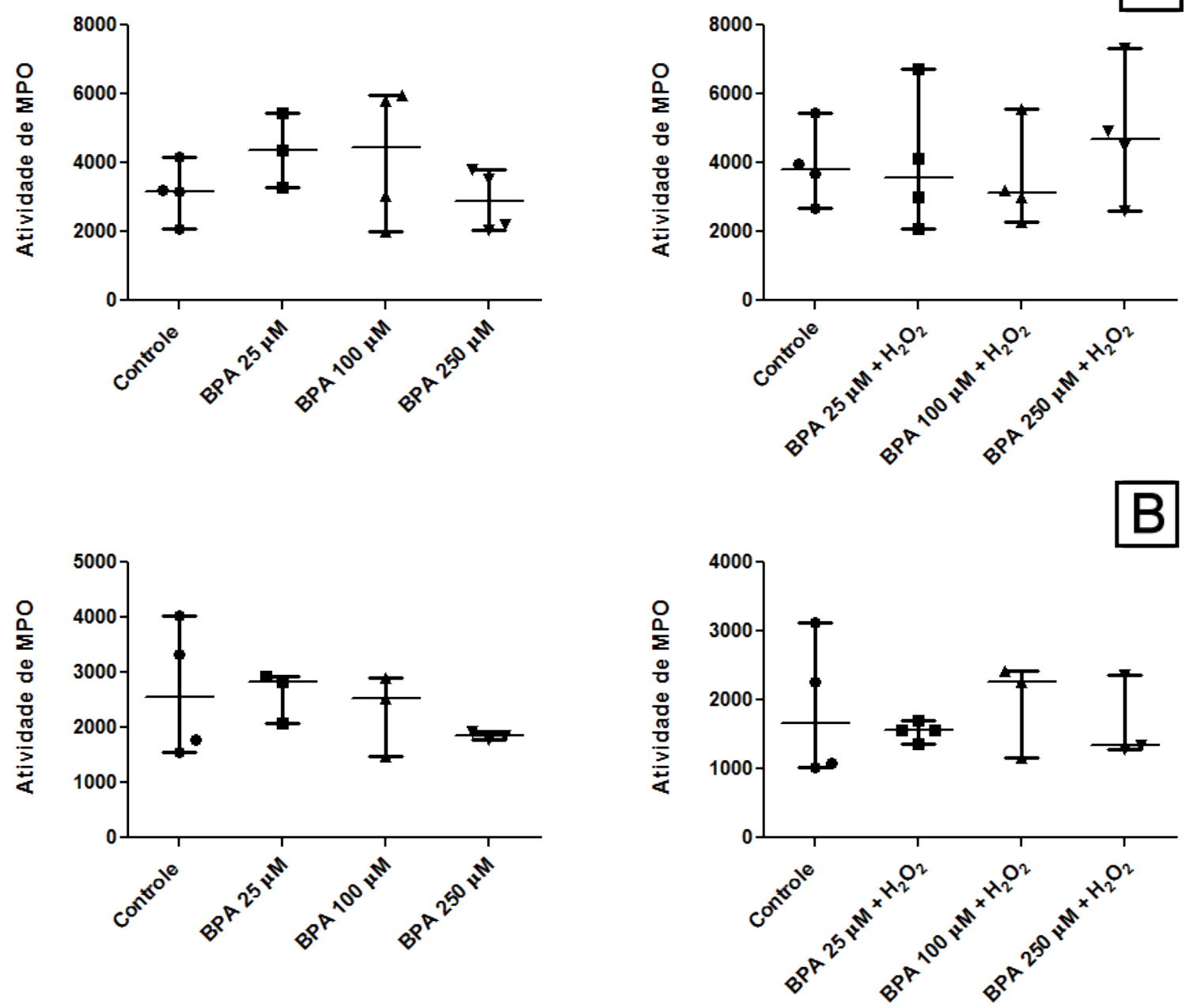

Figura 18 - Atividade de MPO das células HL-60 após: (A) 2 h de incubação com as concentrações indicadas de BPA, com e sem $\mathrm{H}_{2} \mathrm{O}_{2}$ (40 nmol/5 × $10^{4}$ células); (B) $24 \mathrm{~h}$ de incubação com as concentrações indicadas de BPA, com e sem $\mathrm{H}_{2} \mathrm{O}_{2}\left(40 \mathrm{nmol} / 5 \times 10^{4}\right.$ células $)$, média \pm desvio padrão, Kruskal Wallis com pós teste de Dunn, diferenças em relação ao respectivo controle.

Uma vez observada a indução de ROS/RNS nas células incubadas com BPA, avaliou-se a ocorrência de peroxidação lipídica por meio da quantificação de malonaldeído (MDA) no meio de cultura das células. Um cromatograma representativo encontra-se na Figura 19. Observa-se na Figura 20 que não houve alteração da concentração de MDA no meio de cultura das células expostas ao BPA por $24 \mathrm{~h}$, na presença ou ausência de $\mathrm{H}_{2} \mathrm{O}_{2}$, indicando que o 
aumento observado dos níveis de ROS/RNS não foi suficiente para induzir peroxidação lipídica.

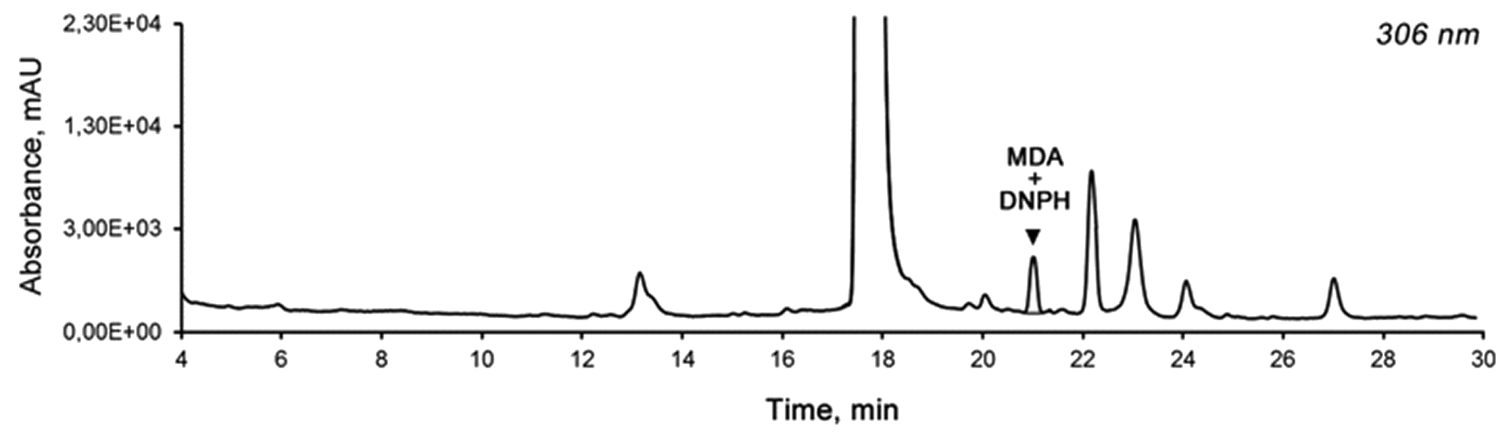

Figura 19 - Cromatograma respresentativo da análise de MDA em meio de cultura. O pico indicado é o produto de reação do MDA presente na amostra com dinitrofenilhidrazina (DNPH), empregado como agente derivatizante.
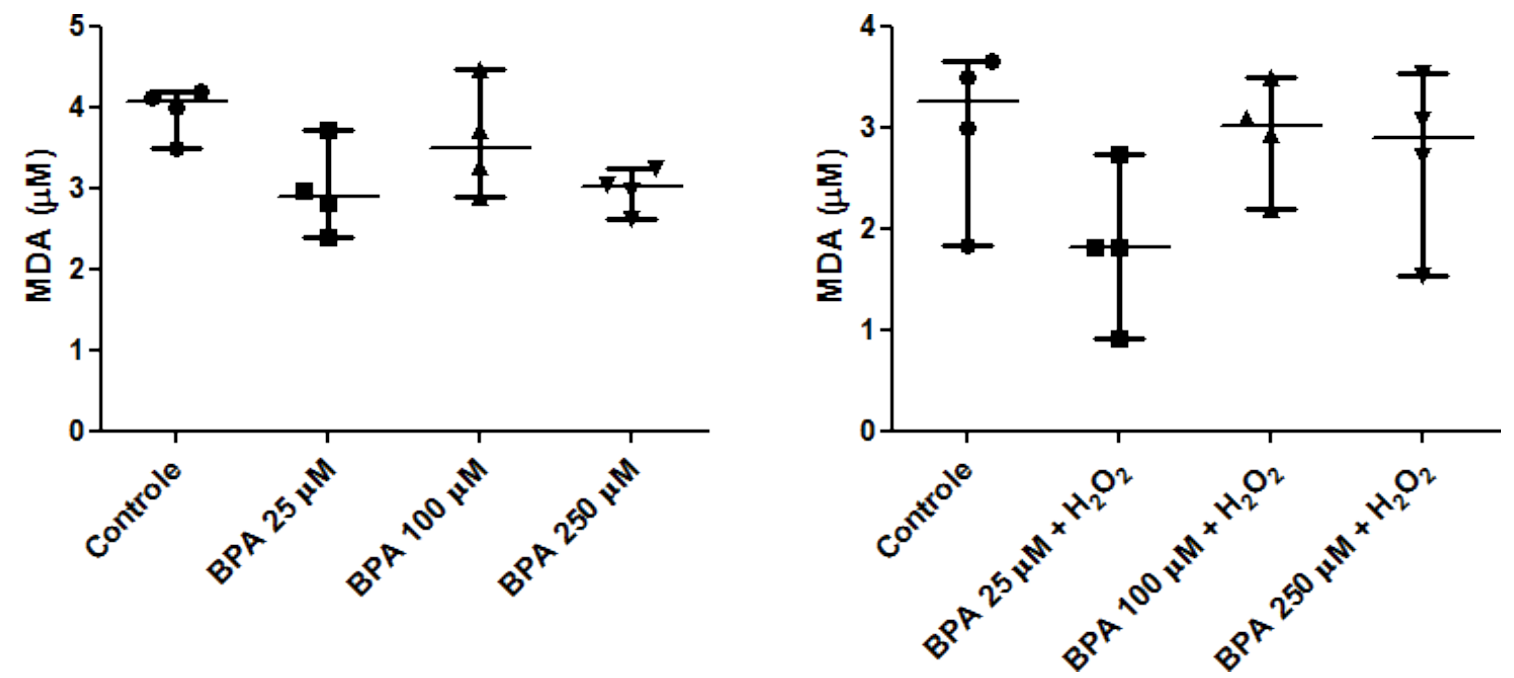

Figura 20 - Concentração de MDA no meio de cultura das células HL-60 após 24 h de incubação com as concentrações indicadas de BPA, sem e com $\mathrm{H}_{2} \mathrm{O}_{2}\left(40 \mathrm{nmol} / 5 \times 10^{4}\right.$ células $)$. $\mathrm{N}=4$, média \pm desvio padrão, Kruskal Wallis com pós-teste de Dunn.

Fragmentação do DNA e alterações do ciclo celular podem ocorrer como resultado da geração excessiva de ROS e ocorrência de danos celulares. Nas figuras 21 e 22 são apresentados os dados obtidos por citometria de fluxo após incubação das células por $24 \mathrm{~h}$ com BPA ou $\mathrm{BPANO}_{2}$, na presença ou ausência de $\mathrm{H}_{2} \mathrm{O}_{2}$. 


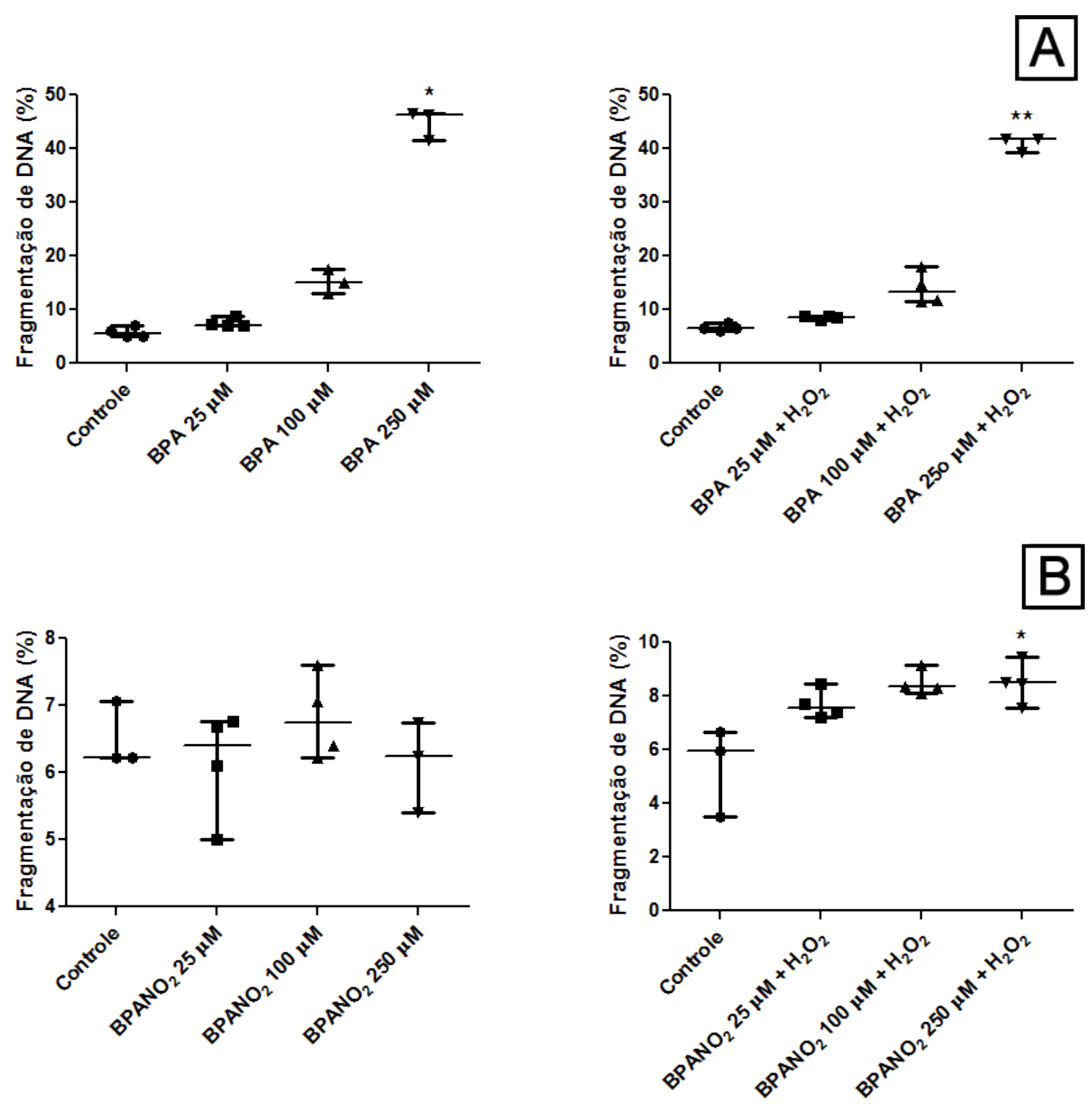

Figura 21 - Fragmentação do DNA das células HL-60 avaliada por citometria de fluxo após $24 \mathrm{~h}$ de incubação com as concentrações indicadas de BPA (A) e $\mathrm{BPANO}_{2}(\mathrm{~B})$, com e sem $\mathrm{H}_{2} \mathrm{O}_{2}\left(40 \mathrm{nmol} / 5 \times 10^{4}\right.$ células). $\mathrm{N}=4$, média \pm desvio padrão, Kruskal Wallis com pós teste de Dunn, diferenças em relação ao respectivo controle. ${ }^{*} \mathrm{P}<0.05 ;{ }^{* *} \mathrm{P}<0.01$. 

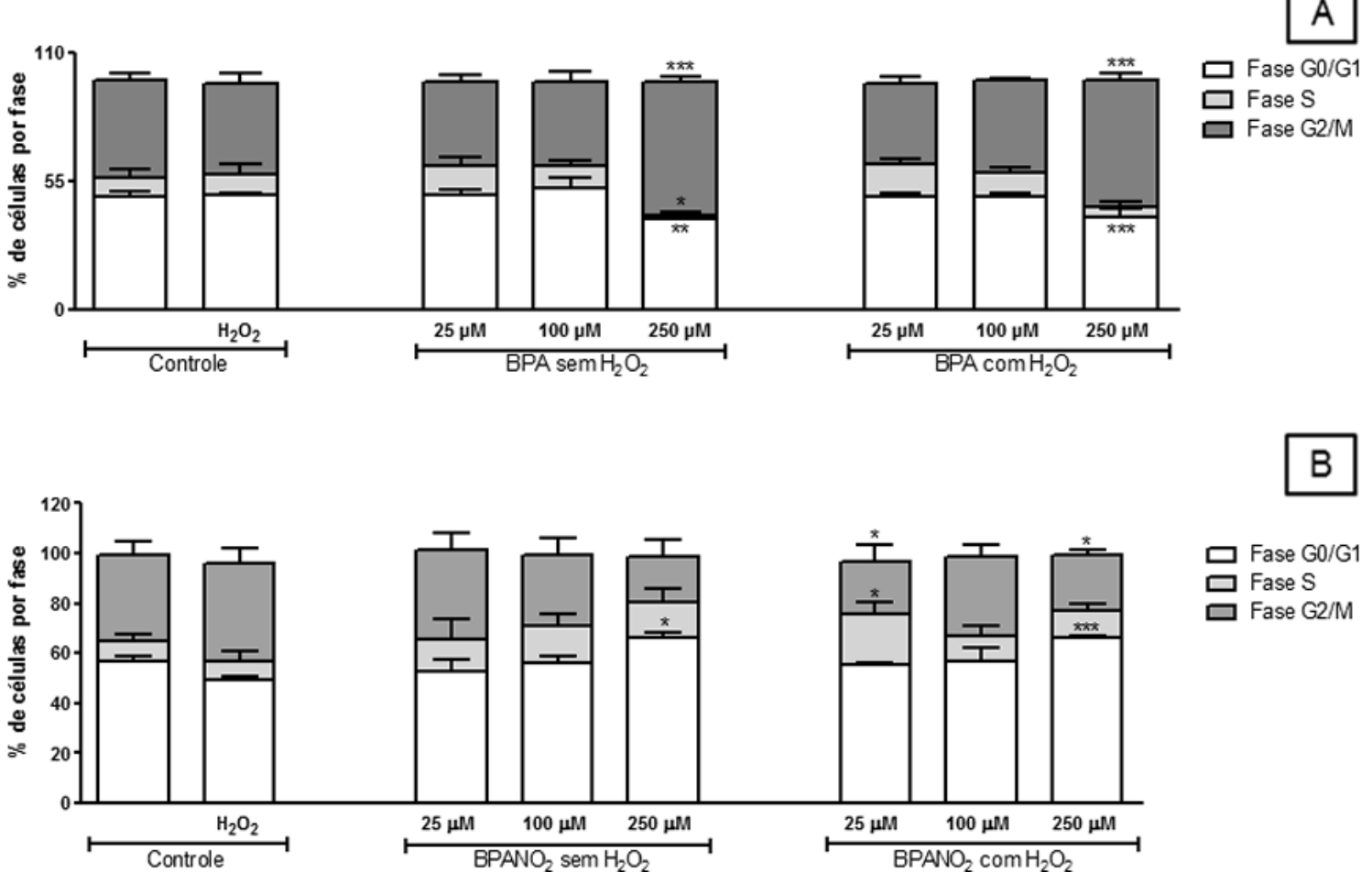

Figura 22 - Fragmentação do DNA das células HL-60 avaliada por citometria de fluxo após $24 \mathrm{~h}$ de incubação com as concentrações indicadas de BPA (A) e $\mathrm{BPANO}_{2}(\mathrm{~B})$, com e sem $\mathrm{H}_{2} \mathrm{O}_{2}\left(40 \mathrm{nmol} / 5 \times 10^{4}\right.$ células). $\mathrm{N}=4$, média \pm desvio padrão, Kruskal Wallis com pós teste de Dunn, diferenças em relação ao respectivo controle. ${ }^{*} \mathrm{P}<0.05 ;{ }^{* *} \mathrm{P}<0.01$.

BPA provocou fragmentação do DNA das células HL-60 na concentração de $250 \mu \mathrm{M}$, independentemente da adição de $\mathrm{H}_{2} \mathrm{O}_{2}$. Na maior concentração testada houve parada do ciclo celular na fase G2/M. Por outro lado, $\mathrm{BPANO}_{2}$ levou à parada do ciclo na fase G0/G1 na maior concentração testada, induzindo discretamente a fragmentação do DNA na presença de $\mathrm{H}_{2} \mathrm{O}_{2}$.

Resumidamente, nesta etapa verificou-se que, apesar da baixa absorção de BPA pelas células HL-60 (Figura 14), na primeira hora de incubação com BPA (100 $\mu \mathrm{M}$ e $250 \mu \mathrm{M})$ houve indução da geração de ROS (Figura 16). Esse efeito foi acompanhado por perda da viabilidade celular (inibição da atividade 
desidrogenase da cadeia respiratória mitocondrial e aumento da permeabilidade da membrana plasmática, principalmente nas incubações com $100 \mu \mathrm{M}$ e $250 \mu \mathrm{M}$, Figuras 12 e 15), aumento da população de células em sub G1, ou seja, com DNA fragmentado (250 $\mu \mathrm{M}$, Figura 21) e parada do ciclo celular na fase G2/M (250 $\mu \mathrm{M}$, Figura 22) no período de $24 \mathrm{~h}$.

Em outro estudo, células de leucemia mielóide humana (NB4, K562 e HL-60) incubadas com BPA por 48 h nas concentrações de 10, 30, 60 e 100 $\mu \mathrm{M}$ sofreram parada do ciclo celular nas fases $\mathrm{G} 1$ ou $\mathrm{G} 2 / \mathrm{M}$, dependendo do tipo celular e da concentração de BPA, e aumento de fragmentação do DNA (fase sub G1) (Bontempo, Mita et al. 2009). Nas células NB4 incubadas com 60 $\mu \mathrm{M}$ de BPA foi verificada indução de apoptose pela ativação das caspases 8,9 e 37, além de aumento da expressão de p21, p27 e p16, diminuição da expressão de ciclina $\mathrm{D} 1$, aumento da fosforilação de BAD e diminuição da fosforilação de ERK, Rb e AKT, alterações moleculares que explicam a parada no ciclo celular e apoptose pelas vias extrínseca e intrínseca. Foi ainda observado aumento da acetilação de histona H3 nas células NB4 incubadas com BPA, um efeito epigenético que altera a expressão gênica. Como as células não expressam receptor de estrógeno, os efeitos são independentes da via estrogênica (Bontempo, Mita et al. 2009).

Em estudo realizado por Watanabe e colaboradores (2003), BPA na concentração de $1 \mathrm{nM}$ aumentou, por via independente de receptores de estrógeno, a geração de radical $\mathrm{O}_{2} \cdot$ estimulada por zymosan opsonizado em células HL-60 submetidas à diferenciação neutrofílica. Aumento da expressão gênica de p47phox e p67phox, componentes do sistema NADPH oxidase, foi também observado. Entretanto, em concentrações no intervalo de 1 - $10 \mu \mathrm{M}$, 
BPA não apresentou efeito no burst respiratório (Watanabe, Adachi et al. 2003).

Sabe-se que diferentes vias de sinalização celular e fatores de transcrição podem ser modulados por ROS, levando as células ao crescimento e replicação ou à parada no ciclo celular e morte. O destino da célula possivelmente depende da fonte de ROS, sua localização e concentração. Assim, baixas concentrações de ROS (nM) estão relacionadas à indução de crescimento, replicação e diferenciação, enquanto maiores concentrações $(\mu M)$ estão relacionadas à indução de morte celular (Chiu and Dawes 2012).

As incubações com $\mathrm{BPANO}_{2}$ por 1 hora levaram a maior geração intracelular de ROS (Figura 17) em comparação às incubações com BPA, sem, no entanto, ser observada perda equivalente da viabilidade celular após $24 \mathrm{~h}$ (foi observado pequeno aumento de permeabilidade da membrana plasmática nas incubações com $250 \mu \mathrm{M}$, revertido após 48 h, sem alteração da atividade desidrogenase da cadeia respiratória mitocondrial, Figuras 14 e 16). Pequeno aumento da população de células em sub G1 (DNA fragmentado) foi observado nas incubações com $250 \mu \mathrm{M}$ na presença de $\mathrm{H}_{2} \mathrm{O}_{2}$ (Figura 22) e parada do ciclo na fase G0/G1 foi observada na maior concentração testada na ausência e presença de $\mathrm{H}_{2} \mathrm{O}_{2}$ (Figura 22). Nas incubações com $25 \mu \mathrm{M}$ de $\mathrm{BPANO}_{2}$ na presença de $\mathrm{H}_{2} \mathrm{O}_{2}$ foi observado aumento da população de células na fase $\mathrm{S}$ e diminuição em G2/M (Figura 22).

Assim, ao compararmos as incubações das células HL-60 com BPA e $\mathrm{BPANO}_{2}$ fica claro que o nível total intracelular de ROS não explica o destino distinto das células nas duas condições. Apesar de as duas moléculas elevarem os níveis celulares de ROS $\left(\mathrm{BPANO}_{2}\right.$ mais do que BPA), BPA inibe a 
cadeia de transporte de elétrons mitocondrial, o que não foi observado para $\mathrm{BPANO}_{2}$. As alterações em diferentes compartimentos celulares e diferenças na composição das espécies reativas geradas devem ativar vias distintas de sinalização, culminando nos diferentes efeitos no ciclo celular e morte.

\subsubsection{Avaliação de efeitos genotóxicos em células HL-60}

O aumento da geração de ROS/RNS nas células HL-60 incubadas com BPA poderia resultar em aumento das lesões 8-oxo-7,8-dihidro-2'desoxiguanosina (8-oxodG), 1, $N^{2}$-eteno-2'-desoxiguanosina $\left(1, N^{2}-\varepsilon d G\right), 1, N^{6}$ etheno-2'-deoxyadenosina $\left(1, N^{6}\right.$-edA) e $\quad N^{2}$-carboxietil-2'-desoxiguanosina (CEdG) no DNA que, sendo reparadas, seriam excretadas para o meio de cultur. Avaliou-se, portanto, os níveis dessas lesões no DNA e/ou meio de cultura das células. Adicionalmente, foi avaliado um marcador de alquilação do DNA, $O^{6}$-metil-2'-desoxiguanosina $\left(0^{6}-\mathrm{mdG}\right)$, que pode ser formado por íons metila resultantes do metabolismo de compostos $N$-nitroso (Dederer, Sokolova et al. 1995); (Gottschalg, Scott et al. 2007). A possibilidade de formação de metabólitos reativos de BPA levando a lesões no DNA também foi investigada pela análise do aduto BPA-Gua tanto no DNA das células, como no meio de cultura. A indução de lesões no DNA pode levar à parada no ciclo celular e morte, além de aumentar a chance de mutações que favorecem a progressão maligna (Roos and Kaina 2013; Yager 2015)

Os métodos de HPLC-ESI-MS/MS para quantificação das lesões em DNA e no meio de cultura foram validados pelo grupo. Dentre as lesões analisadas no DNA das células (8-oxodG, CEdG, $0^{6}-\mathrm{mdG}$ e BPA-Gua) e no meio de cultura (8-oxodG, $1, N^{2}-\varepsilon d G, 1, N^{6}-\varepsilon d A, C E d G, O^{6}-m d G$ e BPA-Gua), foi 
possível quantificar CEdG e 8-oxodG. As demais lesões, se presentes, estavam abaixo dos limites de detecção dos métodos (exemplos de cromatogramas nos quais não há a detecção da lesão são apresentados na figura a seguir, no caso referentes a análises do aduto BPA-Gua em amostras de DNA de fígado. Todas as amostras de DNA de células e tecidos analisadas neste trabalho não apresentaram níveis detectáveis do aduto BPA-Gua).
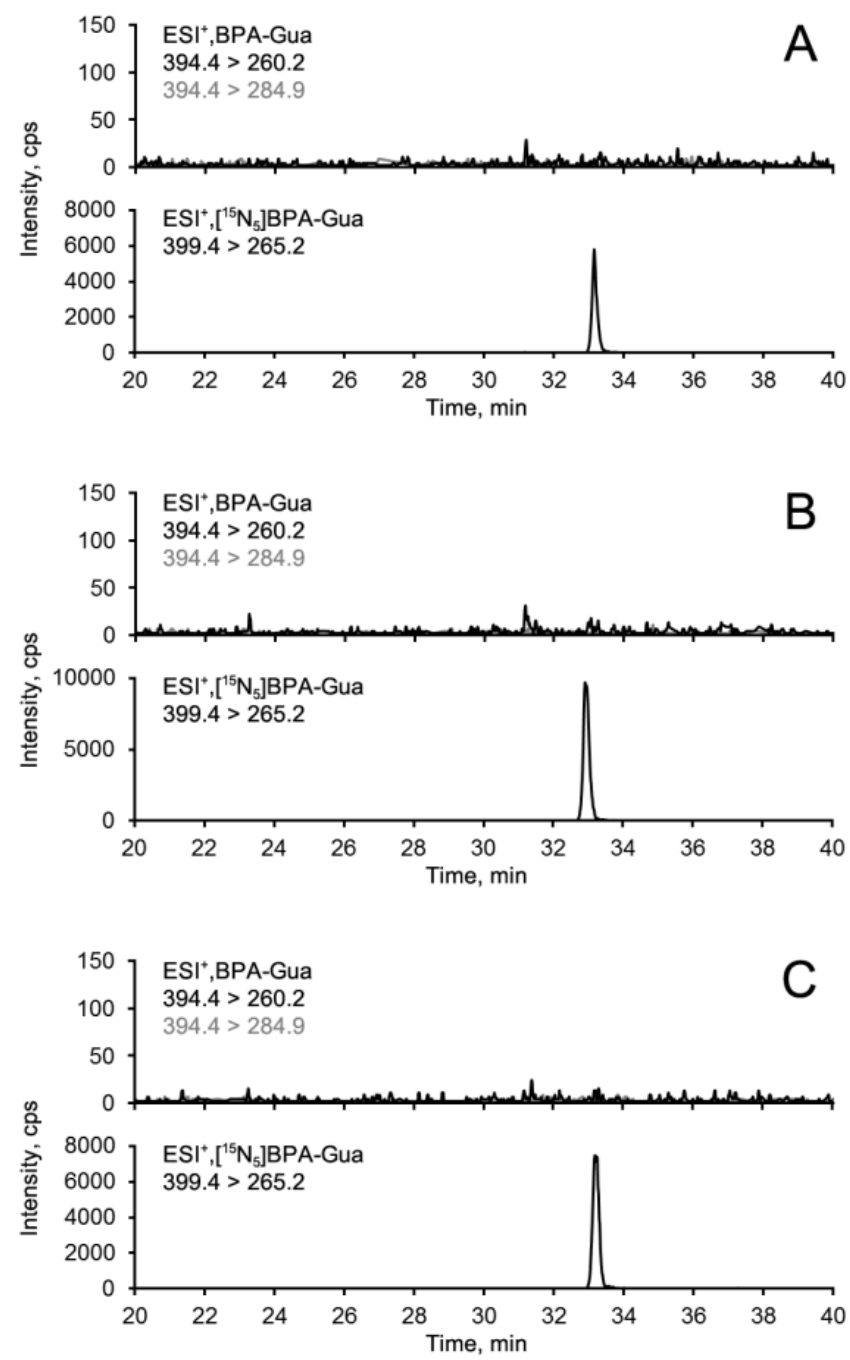

Figura 23 - Cromatogramas obtidos por HPLC-ESI-MS/MS de amostras de DNA de fígado de ratos Sprague-Dawley para análise do aduto BPA-Gua. A) Controle; B) BPA, gavagem, $50 \mathrm{mg} / \mathrm{kg} / \mathrm{dia}, 4$ semanas; C) Diabéticos + BPA (gavagem, $50 \mathrm{mg} / \mathrm{kg} / \mathrm{dia}$, 4 semanas). 
Nas Figuras 24 e 25 são apresentados os níveis de CEdG e 8-oxodG no DNA das células $\mathrm{HL}-60$ incubadas com BPA na presença e ausência de $\mathrm{H}_{2} \mathrm{O}_{2} \mathrm{e}$ nas respectivas amostras de meio de cultura.
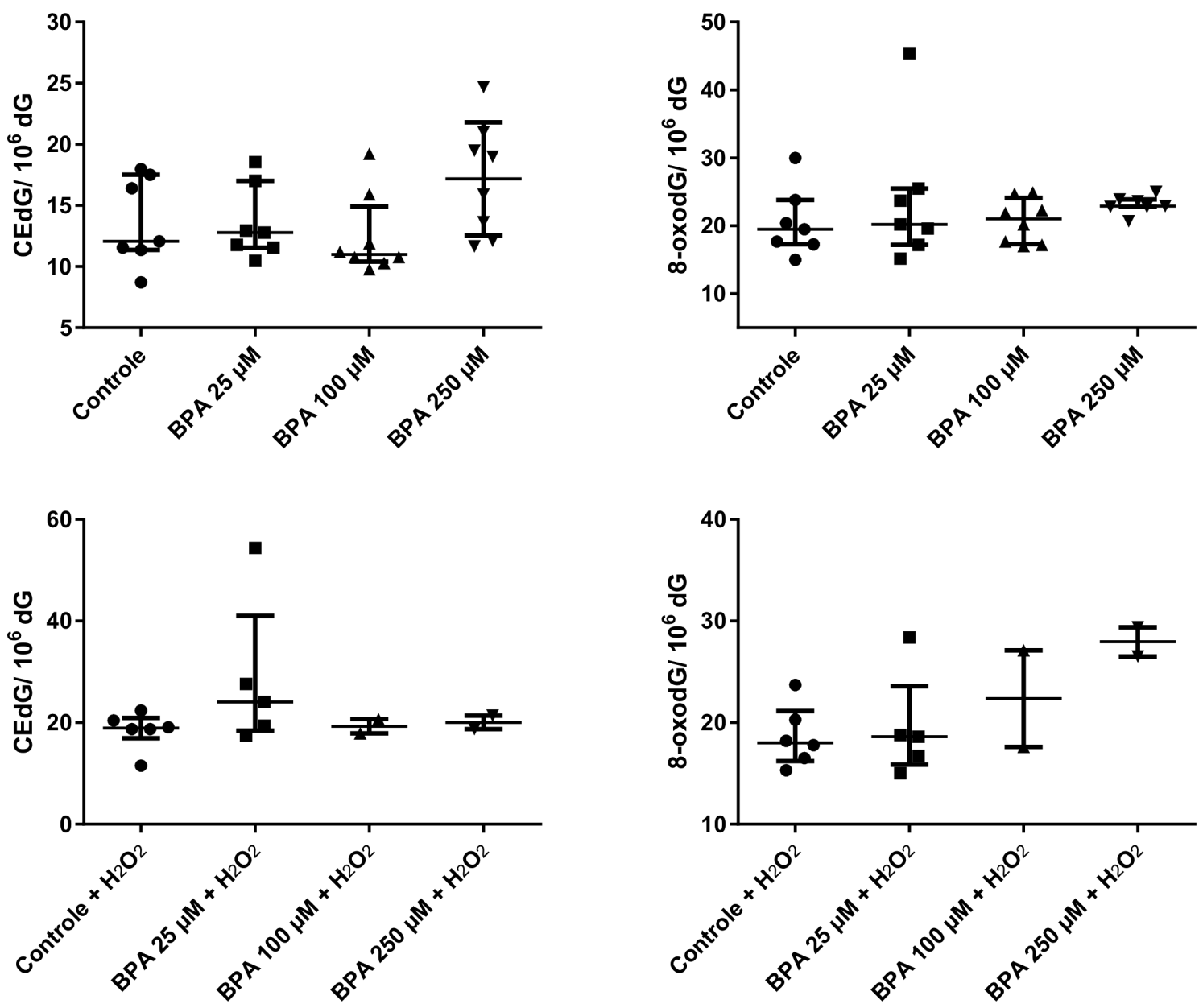

Figura 24 - Níveis de CEdG e 8-oxodG em DNA de células HL-60 incubadas com BPA com ou sem $\mathrm{H}_{2} \mathrm{O}_{2}$

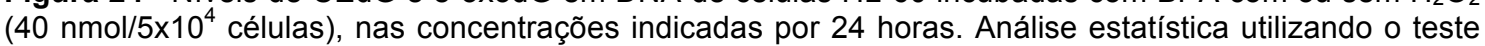
de Kruskal Wallis com pós teste de Dunn não mostrou diferença entre os grupos. 

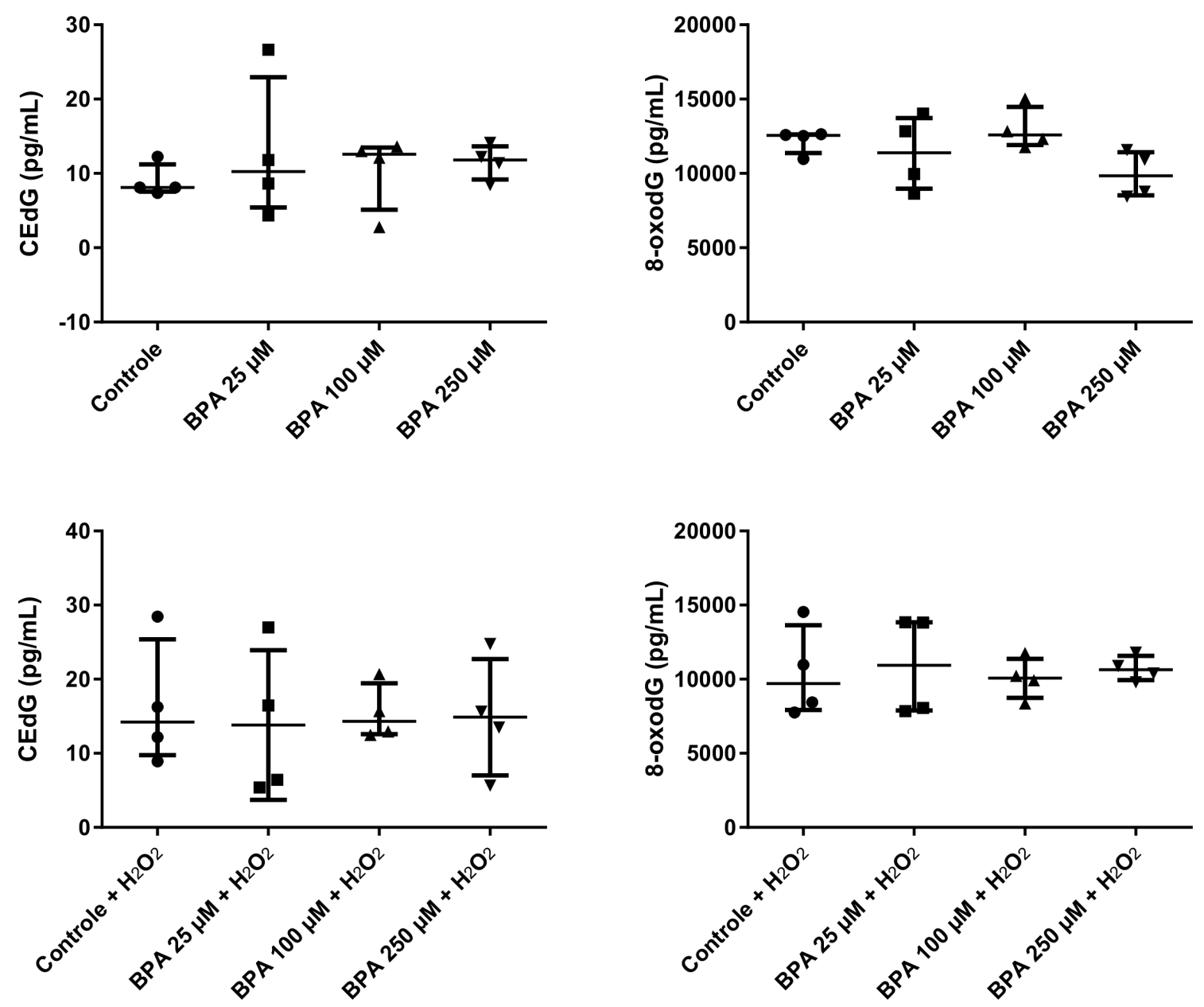

Figura 25 - Níveis de CEdG e 8-oxodG no meio de cultura (meio RPMI suplementado com 10\% de SFB) de células $\mathrm{HL}-60$ incubadas com BPA, com e sem $\mathrm{H}_{2} \mathrm{O}_{2}\left(40 \mathrm{nmol} / 5 \times 10^{4}\right.$ células), nas concentrações indicadas por 24 horas. Análise estatística utilizando o teste de Kruskal Wallis com pós teste de Dunn não mostrou diferença entre grupos.

Observa-se que as incubações com BPA não levaram ao aumento dos níveis das lesões no DNA ou ao aumento da excreção das lesões para o meio de cultura. Como apresentado anteriormente, também não foi observado aumento dos níveis de malonaldeído, um outro marcador de dano oxidativo, no meio de cultura das células. Assim, é possível que em resposta ao aumento da geração de ROS na presença de BPA, as células tenham aumento da expressão de enzimas antioxidantes, que acabam protegendo contra a indução de lesões em biomoléculas por radicais livres. O fator de transcrição Nrf2 é 
ativado na presença de ROS e induz a expressão de genes que estão sob controle do elemento responsivo a antioxidantes (ARE), tais como glutationa-Stransferase, $\gamma$-glutamilcisteína sintetase, glutationa redutase, glutationa peroxidase, peroxirredoxina, tiorredoxina, tiorredoxina redutase, catalase, SOD, sulfirredoxina e enzimas de biotransformação de fase II (Chiu and Dawes 2012). Essa resposta ao estresse inicial pode também explicar a resistência das células à perda de viabilidade com o passar do tempo de incubação (Figura 12).

De fato, em estudo com células renais embrionárias humanas (HEK 293) foi verificado que BPA nas concentrações de $100-200 \mu \mathrm{M}$ ativa os fatores de transcrição Nrf1 e Nrf2 e aumenta a transcrição de genes sob controle de ARE, como heme oxigenase-1 (ho-1) e NADPH quinona desidrogenase 1 (Nqo1). Aumento da razão GSH/GSSG foi também observado. Nessas células, quantidades de BPA na ordem de 50 - $200 \mathrm{ng}$ foram encontradas em frações subcelulares, principalmente na mitocôndria e citoplasma. Não houve indução de ROS ou perda de viabilidade celular no período de 24 h (Chepelev, Enikanolaiye et al. 2013).

As análises no meio de cultura das células nos permitiram, adicionalmente, detectar concentrações altas das lesões CEdG $(21,1 \pm 3,3$ $\mathrm{pg} / \mathrm{mL})$ e 8-oxodG $(6829 \pm 855 \mathrm{pg} / \mathrm{mL})$ mesmo na ausência de células, tendo como provável fonte o soro fetal bovino utilizado na composição do meio. $\mathrm{Na}$ presença das células, as concentrações de CEdG no meio de cultura diminuiram, enquanto que as de 8-oxodG aumentaram (Figura 25).

As células HL-60 foram também incubadas com $\mathrm{BPANO}_{2}$, na ausência e presença de $\mathrm{H}_{2} \mathrm{O}_{2}$, e o DNA extraído para análise das lesões 8-oxodG, CEdG, 
$0^{6}$-mdG e BPA-Gua. Da mesma forma, foi possível quantificar as lesões 8oxodG e CEdG, não tendo sido detectadas as demais. Os dados estão apresentados na figura a seguir, observando-se aumento dos níveis de CEdG nas células incubadas com $100 \mu \mathrm{M}$ de $\mathrm{BPANO}_{2}$ na presença de $\mathrm{H}_{2} \mathrm{O}_{2}$.
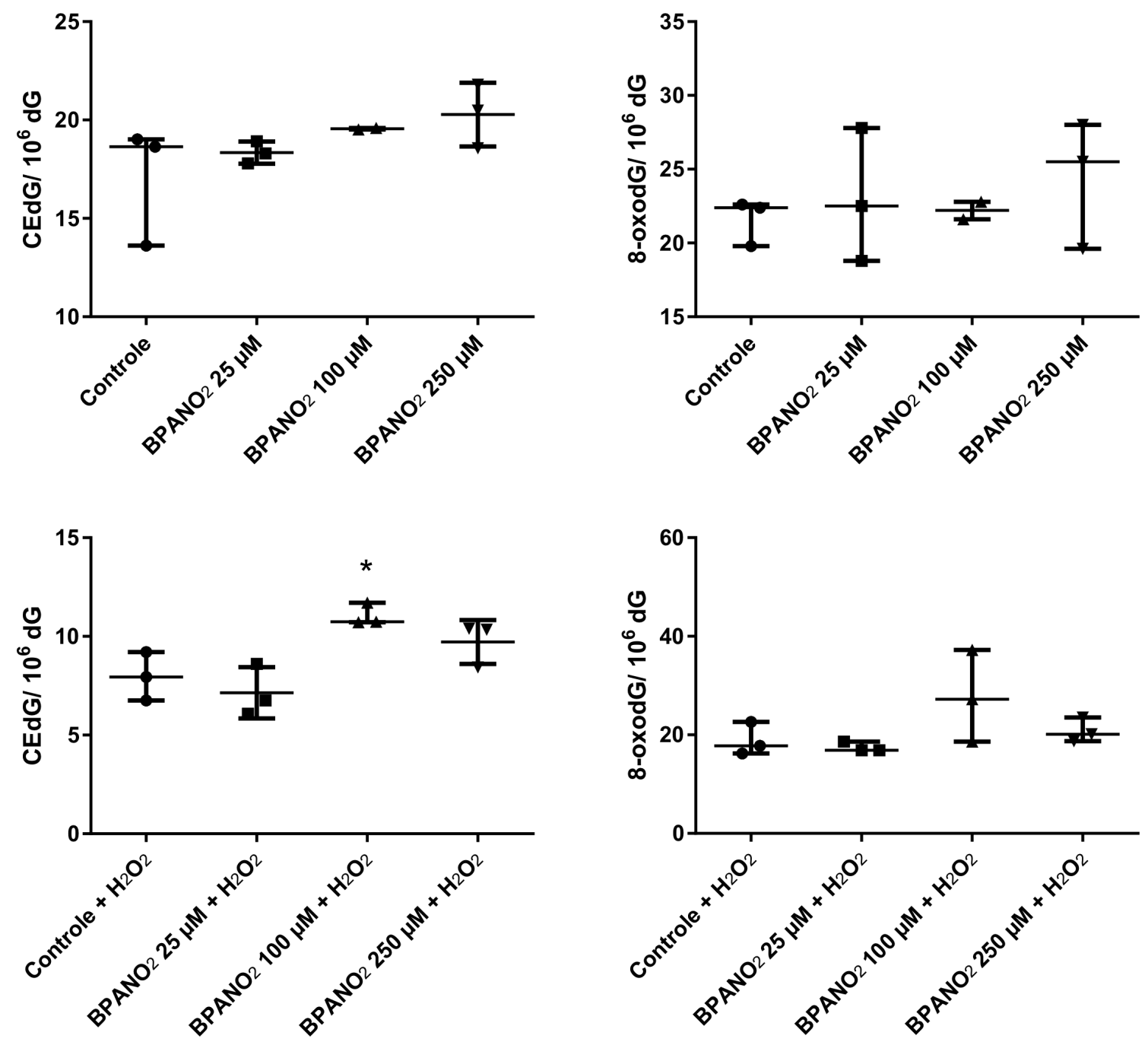

Figura 26 - Níveis de CEdG e 8-oxodG em DNA de células HL-60 incubadas com $\mathrm{BPANO}_{2}$, com e sem $\mathrm{H}_{2} \mathrm{O}_{2}$ (40 nmol $/ 5 \times 10^{4}$ células), nas concentrações indicadas pelo período de 24 horas. ${ }^{*} \mathrm{P}<0,05 \mathrm{em}$ comparação com o controle, de acordo com o teste de Kruskal Wallis com pós teste de Dunn.

O aduto CEdG observado em nível aumentado no DNA das células incubadas com BPANO $2(100 \mu \mathrm{M})$, mas não com BPA, pode resultar da reação de metilglioxal com o grupo amino exocíclico da guanina (Chepelev, Enikanolaiye et al. 2013). Algumas fontes de metilglioxal são o processo de 
peroxidação lipídica, degradação enzimática ou não enzimática de dihidroxiacetona fosfato (intermediário da via glicolítica), metabolismo de acetona, glicerol, glicina e treonina (Vistoli, De Maddis et al. 2013). O acúmulo de CEdG no DNA pode levar a alterações da expressão gênica, da atividade de proteínas (Breyer, Frischmann et al. 2008) e aumento de mutações (Cao, Jiang et al. 2007; Tamae, Lim et al. 2011), eventos relacionados ao desenvolvimento de doenças. A indução de formação de CEdG nas células incubadas com $\mathrm{BPANO}_{2}$, mas não com BPA, pode ser reflexo de alterações induzidas por essas moléculas em diferentes compartimentos celulares, como discutido no item anterior.

\subsubsection{Avaliação de efeitos epigenéticos em células HL-60}

Alterações epigenéticas podem contribuir para a expressão diferencial de genes, levando a diversas consequências, tais como alterações no sistema de reparo, no ciclo celular e em vias metabólicas. Uma importante modificação epigenética em genoma de mamíferos é a metilação na posição $C-5$ da citosina (5-metilcitosina ou 5-mdC), cujo padrão é mantido no genoma ao longo das gerações celulares. A metilação do DNA é um evento regulado pela ação de DNA metil-transferases (DNMTs). O processo de desmetilação do DNA, por sua vez, envolve a oxidação de 5-mdC para 5-hidroximetilcitosina (5-hmdC) por uma família de dioxigenases dependentes de a-cetoglutarato e $\mathrm{Fe}(\mathrm{II})$, denominadas proteínas Ten-Eleven-Translocation (TET1, TET2 e TET3). As marcas epigenéticas 5-mdC e 5-hmdC são importantes para a regulação da expressão gênica (Valinluck and Sowers 2007; Tahiliani, Koh et al. 2009; Ito, 
D'Alessio et al. 2010; Jin, Kadam et al. 2010; Dahl, Gronbaek et al. 2011; Williams, Christensen et al. 2012).

Um método de HPLC-ESI-MS/MS foi padronizado pelo grupo para quantificação simultânea de 5-mdC e 5-hmdC no DNA. A espectrometria de massas permite especificidade para a quantificação dos analitos e o uso de pequenas quantidades de DNA. Para a quantificação de 5-mdC por HPLC-UV são necessários pelo menos $5 \mu \mathrm{g}$ de DNA, enquanto que a quantificação por HPLC-ESI-MS/MS é possível com o uso de 100 vezes menos DNA. No caso de 5-hmdC, devido às baixas concentrações no DNA, não é possível sua quantificação por HPLC-UV.

Células HL-60 foram incubadas com BPA e $\mathrm{BPANO}_{2}$, na ausência e presença de $\mathrm{H}_{2} \mathrm{O}_{2}$, e o DNA extraído para quantificação de 5-mdC e 5-hmdC. Os dados estão apresentados nas figuras a seguir.

Foi observada hipermetilação (5-mdC) do DNA das células HL-60 incubadas com BPA e simultânea queda dos níveis de 5-hmdC. A hipermetilação foi atenuada e não houve alteração dos níveis de 5-hmdC quando as incubações ocorreram na presença de $\mathrm{H}_{2} \mathrm{O}_{2}$ (Figura 27). Essas alterações no período de $24 \mathrm{~h}$ de incubação evidenciam a possível ação do BPA na modulação da atividade de enzimas responsáveis pela manutenção do padrão de metilação do DNA. A ação pode ser direta ou mediada por alterações metabólicas que acabam levando, por exemplo, à inibição de TET. É sugerido que a perda de função das proteínas TET pode levar à hipermetilação de regiões promotoras de genes, com consequente desregulação da transcrição e diferenciação celular (Williams, Christensen et al. 2012). Vale ressaltar que TET2 é frequentemente mutada em neoplasmas mieloides e que 
TET1 e TET2 são frequentemente mutadas em gliomas (Chia, Wang et al. 2011). Uma vez que as proteínas TET são dependentes de $\alpha$-cetoglutarato para sua atividade catalítica, alterações no ciclo do ácido tricarboxílico podem levar a alterações dos níveis de 5-mdC e 5-hmdC no DNA (Chia, Wang et al. 2011).
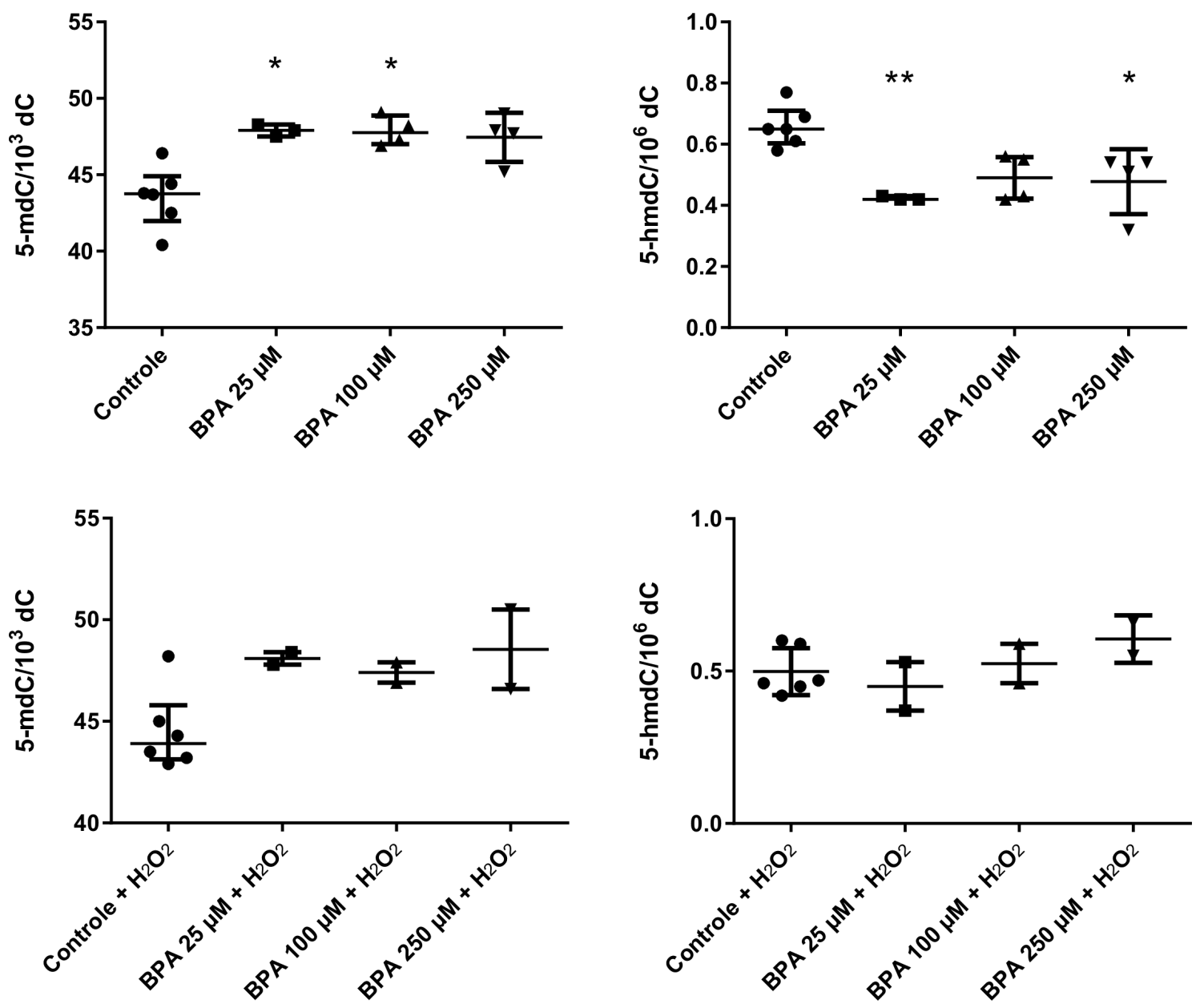

Figura 27 - Níveis de 5-mdC e 5-hmdC em DNA de células HL-60 incubadas com BPA, sem e com $\mathrm{H}_{2} \mathrm{O}_{2}$ ( $40 \mathrm{nmol} / 5 \times 10^{4}$ células), nas concentrações indicadas por $24 \mathrm{~h}$. ${ }^{*} \mathrm{P}<0,05,{ }^{* *} \mathrm{P}<0,01$ comparando-se os diferentes grupos com o controle, de acordo com teste de Kruskal Wallis com pós teste de Dunn.

Nas incubações com $25 \mu \mathrm{M}$ de BPA não foi observado aumento dos níveis intracelulares de ROS e alteração do ciclo celular (incluindo células em sub G1). Foi observado pequeno aumento da permeabilidade da membrana plasmática após 24 h, mas não após 48 h de incubação, e pouca inibição da 
atividade desidrogenase da cadeia respiratória mitocondrial após 24 h. Assim, o efeito epigenético observado na Figura 27 ocorreu na ausência de citotoxicidade e é possível que se manifeste em concentrações inferiores de BPA, o que merece ser investigado.

Em análise metabolômica utilizando urina de ratos expostos a BPA (administração oral, $0,5 \mu \mathrm{g} / \mathrm{kg} / \mathrm{dia}$ e $50 \mathrm{mg} / \mathrm{kg} / \mathrm{dia}$, 8 semanas), Chen e colaboradores (2014) revelaram que BPA aumentou a excreção de biotina e riboflavina, a síntese de produtos metilados, o catabolismo de purinas e o fluxo pela via do metabolismo da colina, que leva à geração de metionina. No fígado dos ratos expostos mesmo à menor dose de BPA foram observados níveis aumentados de S-adenosilmetionina (SAMe) e das enzimas que catalizam a síntese de SAMe a partir de metionina. SAMe é o principal doador biológico de grupo metila para reações de metilação endógena, incluindo a metilação da citosina no DNA (Chen et al., 2014). Esse tipo de alteração metabólica induzida por BPA levaria ao aumento da atividade de DNA metiltransferases (DNMTs) e, consequentemente, ao aumento dos níveis de 5-mdC no DNA. Foi verificada atividade aumentada de DNMT3 em fígado de ratos expostos a BPA (Ma, Xia et al. 2013).

Muitos estudos tem sido conduzidos visando esclarecer se e como a exposição perinatal ao BPA pode levar a maior suscetibilidade a doenças cardiovasculares, diabetes, câncer, síndrome metabólica na idade adulta. Alterações do padrão de metilação do DNA tem sido reveladas em diferentes tecidos de ratos e camundongos no intervalo de dias, semanas e meses após a exposição no período perinatal, o que pode justificar a modulação da 
susceptibilidade a doenças (van Esterik et al., 2015). Embora a variedade de métodos existentes para as análises de metilação do DNA dificulte a observação de um padrão comum de alteração, o conjunto dos trabalhos mostra que a exposição ao BPA leva a alterações da metilação do DNA durante o desenvolvimento fetal, o que pode favorecer a ocorrência de doenças na idade adulta. Entretanto, é importante considerar também que BPA pode alterar o padrão de metilação do DNA de células somáticas de indivíduos jovens/adultos, também favorecendo o desenvolvimento de doenças. Assim, é importante entender como as alterações metabólicas induzidas por BPA estão relacionadas com alterações epigenéticas e o risco de doenças.

Não há dados na literatura sobre alterações dos níveis de 5-mdC e 5hmdC no DNA de células HL-60 expostas a BPA.

Quanto à exposição das células $\mathrm{HL}-60$ a $\mathrm{BPANO}_{2}$, verificou-se queda dos níveis de 5-hmdC no DNA das incubações na presença de $\mathrm{H}_{2} \mathrm{O}_{2}$, não acompanhada de aumento dos níveis de 5-mdC. Uma vez que as alterações metabólicas induzidas por $\mathrm{BPANO}_{2}$ são diferentes das induzidas por BPA, é possível que os efeitos na maquinaria epigenética também sejam diferentes. É importante notar que nessas células foi observado aumento dos níveis de CEdG no DNA, o que pode afetar a atividade de DNMTs ou favorecer a desmetilação do DNA por vias de reparo de lesões (Franchini et al., 2014). 

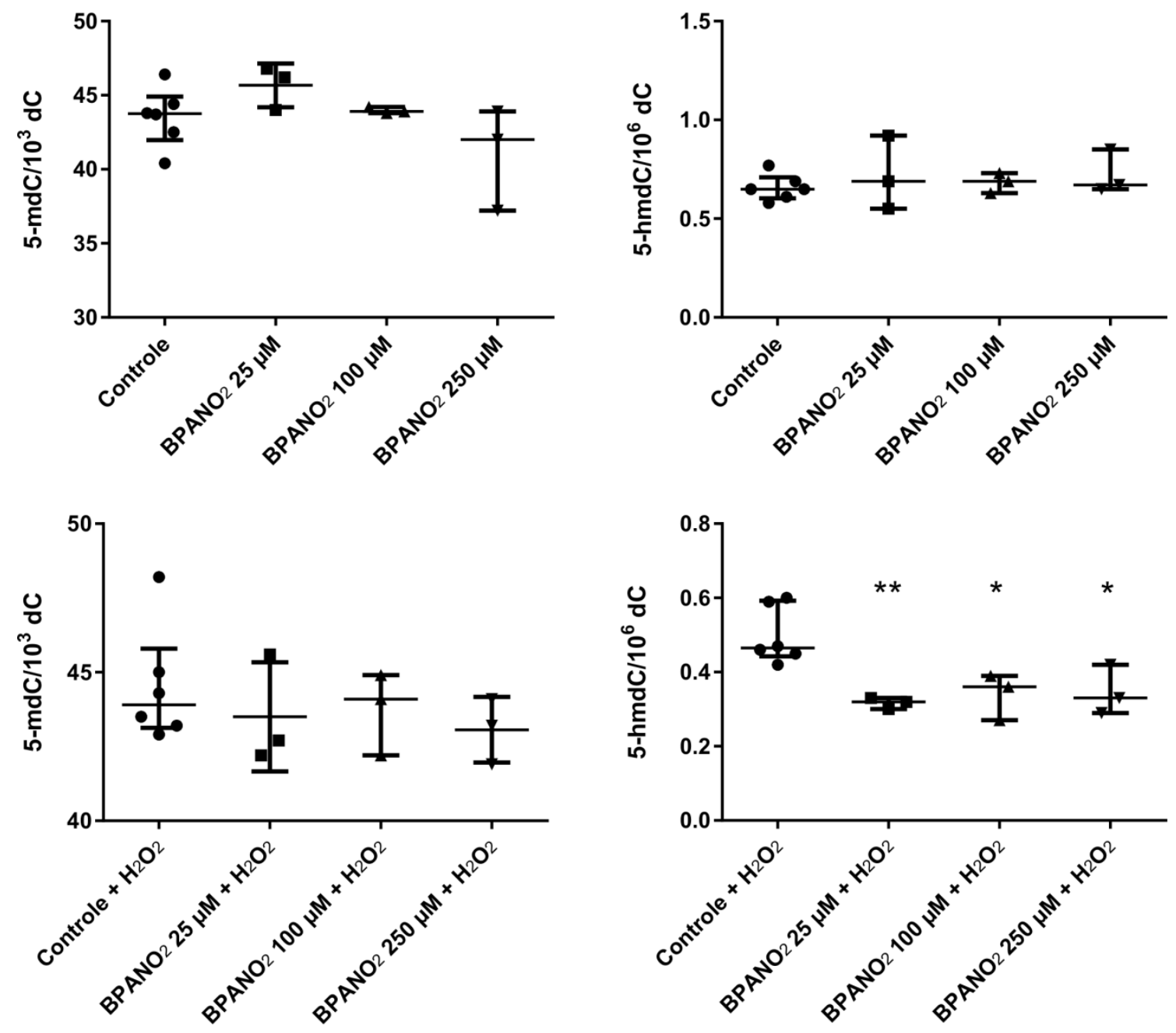

Figura 28 - Níveis de 5-mC e 5-hmC em DNA de células HL-60 incubadas com $\mathrm{BPANO}_{2}$ com ou sem $\mathrm{H}_{2} \mathrm{O}_{2}$ (40 nmol/5x10 células), nas concentrações indicadas por 24 horas. ${ }^{*} \mathrm{P}<0,05$; ${ }^{* *} \mathrm{P}<0,01$ comparandose os diferentes grupos com o controle, de acordo com teste de Kruskal Wallis com pós teste de Dunn. 


\subsection{Efeitos citotóxicos, genotóxicos e epigenéticos em células MCF-7 expostas a BPA e $\mathrm{BPANO}_{2}$}

\subsubsection{Avaliação da citotoxicidade em células MCF-7}

As células MCF-7 são derivadas de adenocarcinoma mamário humano e apresentam receptores de estrógeno, podendo sofrer a ação estrogênica do BPA (Dong, Terasaka et al. 2011). Além disso, células MCF-7 apresentam atividade de citocromo P450 1A1 e 1B1 quando estimuladas com agonistas do receptor de hidrocarboneto aromático (receptor Ah), por exemplo 2,3,7,8tetraclorodibenzo-p-dioxina (TCDD) e bifenilas policloradas (PCB). Permitem, então, a investigação de como outras possíveis vias de ação do BPA modulam os efeitos tóxicos. As células cresceram aderidas à placa de cultura, utilizandose meio DMEM com $10 \%$ de SFB e sem fenol vermelho para evitar a interferência estrogênica. Todos os procedimentos foram realizados como descrito para as células $\mathrm{HL}-60$, com exceção da adição de $\mathrm{H}_{2} \mathrm{O}_{2}$.

Nas figuras 28 a 32 são apresentados os dados de viabilidade celular (citometria de fluxo), geração de ROS/RNS, fragmentação do DNA e ciclo celular nas diferentes condições de incubação.

As células MCF-7 apresentaram aumento da permeabilidade da membrana plasmática quando expostas por $1 \mathrm{~h}$ (4\% de morte) ou 24 h (12\% de morte) ao BPA na concentração de $250 \mu \mathrm{M}$ (Figura 28).

A exposição ao $\mathrm{BPANO}_{2}$ por 1 hora não induziu morte celular nas

concentrações de 25, 100 ou $250 \mu \mathrm{M}$, (Figura 29A). Contudo, quando o período de exposição foi estendido para 24 horas, os resultados obtidos 
mostraram que houve morte celular nas concentrações de $25 \mu \mathrm{M}(13,2 \%$ de morte) e $250 \mu \mathrm{M}(19,8 \%$ de morte) (Figura 29B).

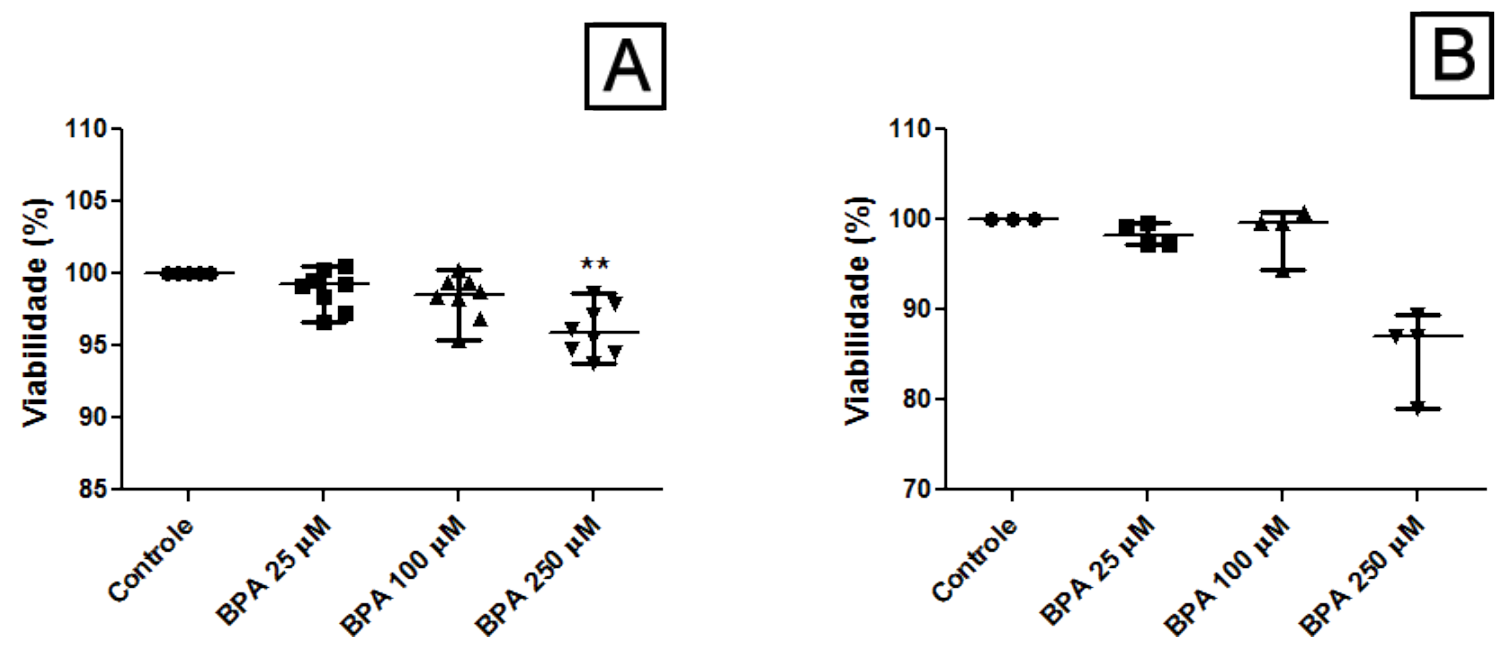

Figura 29 - Viabilidade das células MCF-7 avaliada por citometria de fluxo após: A) $1 \mathrm{~h}$ de incubação com as concentrações indicadas de BPA; B) $24 \mathrm{~h}$ de incubação com as concentrações indicadas de BPA, média \pm desvio padrão, Kruskal Wallis com pós teste de Dunn, diferenças em relação ao controle.

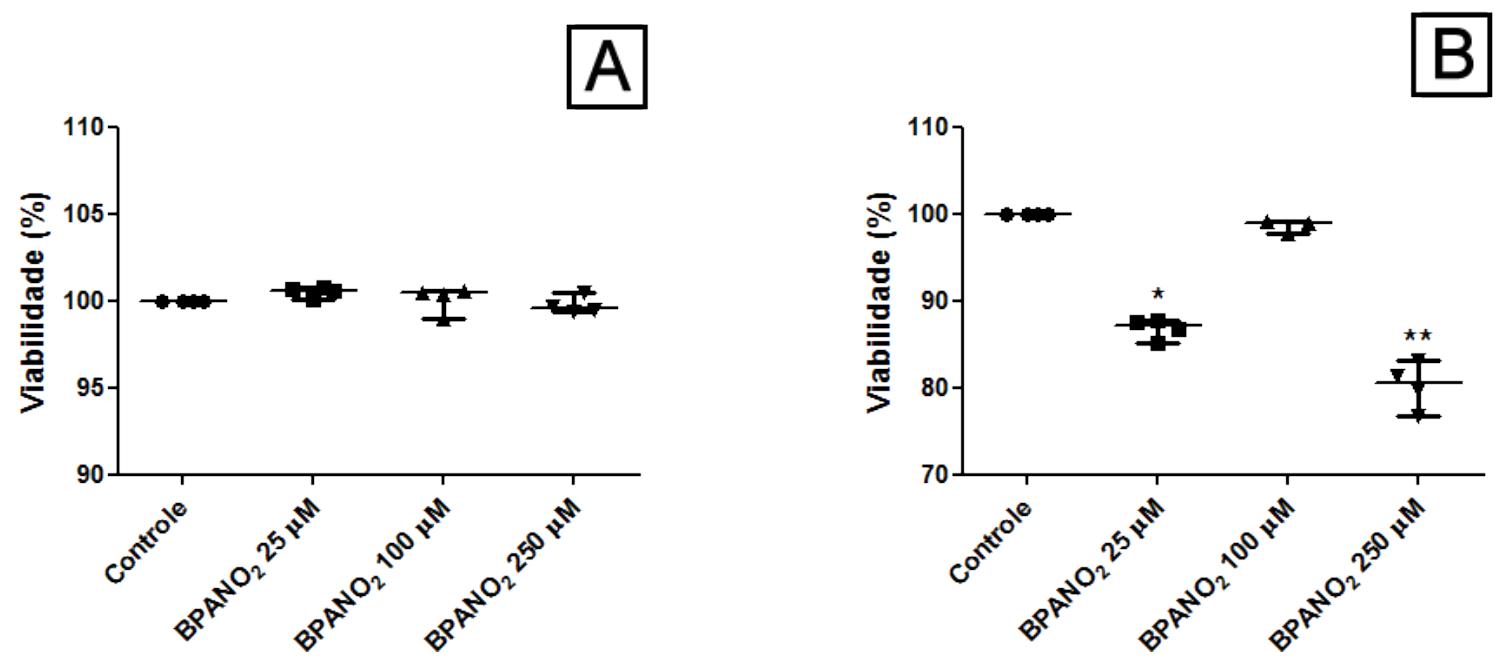

Figura 30 - Viabilidade das células MCF-7 avaliada por citometria de fluxo após: A) 1 h de incubação com as concentrações indicadas de $\mathrm{BPANO}_{2}$; B) $24 \mathrm{~h}$ de incubação com as concentrações indicadas de $\mathrm{BPANO}_{2} . \mathrm{N}=4$, média \pm desvio padrão, teste de Kruskal Wallis com pós teste de Dunn, diferenças em relação ao controle. ${ }^{*} \mathrm{P}<0.05 ;{ }^{* *} \mathrm{P}<0.01$.

Células MCF-7 expostas ao BPA por 1 hora não sofreram alteração da produção intracelular de ROS/RNS, contudo a exposição ao $\mathrm{BPANO}_{2}$ levou à diminuição significativa de ROS/RNS na concentração de $100 \mu \mathrm{M}$ (Figura 30A). Estendendo-se a exposição a BPA para $24 \mathrm{~h}$, foi observado aumento 
significativo da produção de ROS/RNS nas células expostas a $25 \mu \mathrm{M}$, seguido por diminuição significativa na concentração de $250 \mu \mathrm{M}$. Tais alterações não foram observadas na exposição ao $\mathrm{BPANO}_{2}$ (Figura 30B).

Houve aumento da fragmentação do DNA de células MCF-7 expostas ao BPA na concentração de $250 \mu \mathrm{M}$ por 24 horas (Figura 31A). Quando as células foram expostas ao $\mathrm{BPANO}_{2}$ por 24 horas, não houve fragmentação do DNA (Figura 31B).

A exposição ao BPA não induziu alterações no ciclo celular. Contudo, a exposição ao $\mathrm{BPANO}_{2}$ provocou diminuição da porcentagem de células na fase G0/G1 e aumento na fase G2/M. Esse efeito foi observado em todas as concentrações de $\mathrm{BPANO}_{2}$, como apresentado na figura 32.
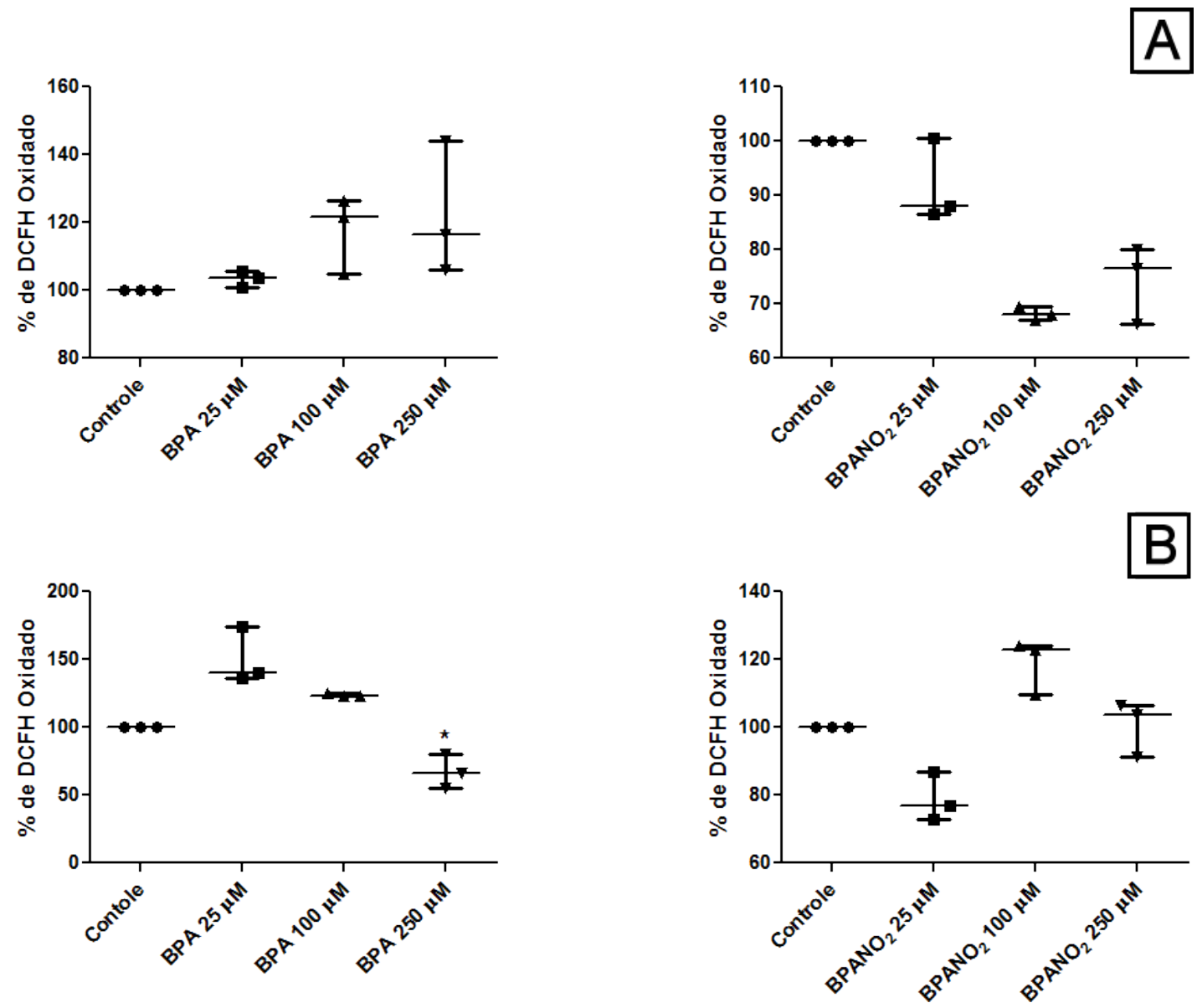

Figura 31 - Fluorescência relativa (\%) do produto DCF nas células MCF-7 após A) $1 \mathrm{~h}$ de incubação com as concentrações indicadas de BPA e $\mathrm{BPANO}_{2}$; $\left.\mathrm{B}\right) 24 \mathrm{~h}$ de incubação com as concentrações indicadas de BPA e $\mathrm{BPANO}_{2} . \mathrm{N}=4$, média \pm desvio padrão, Kruskal Wallis com pós teste de Dunn, diferenças em relação ao controle. ${ }^{*} \mathrm{P}<0,05$. 


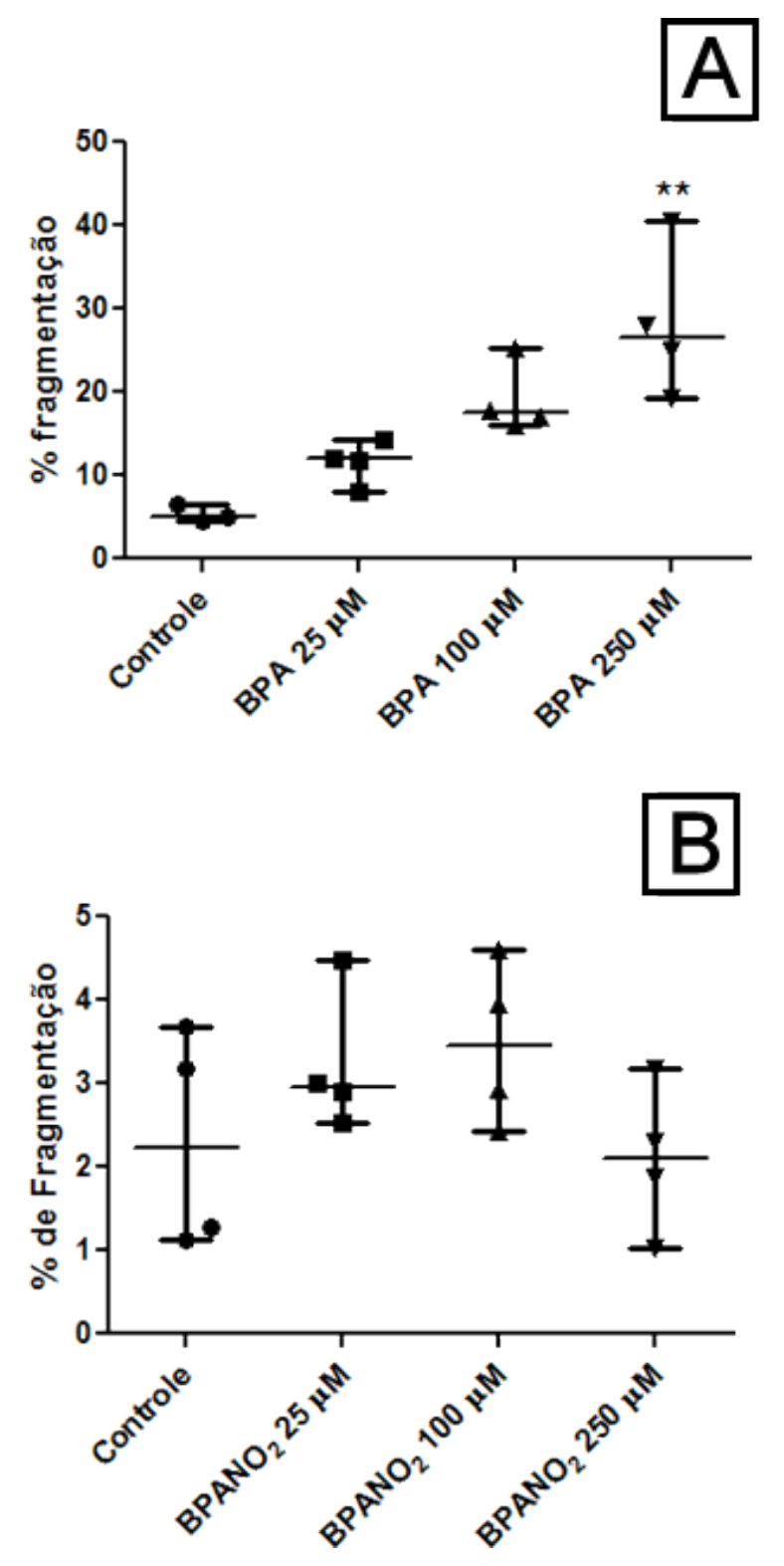

Figura 32 - Fragmentação do DNA das células MCF-7 avaliada por citometria de fluxo após 24 h de incubação com as concentrações indicadas de BPA (A) e $\mathrm{BPANO}_{2}$ (B). $\mathrm{N}=4$, média \pm desvio padrão, Kruskal Wallis com pós teste de Dunn, diferenças em relação ao controle. ${ }^{* *} \mathrm{P}<0.01$ 

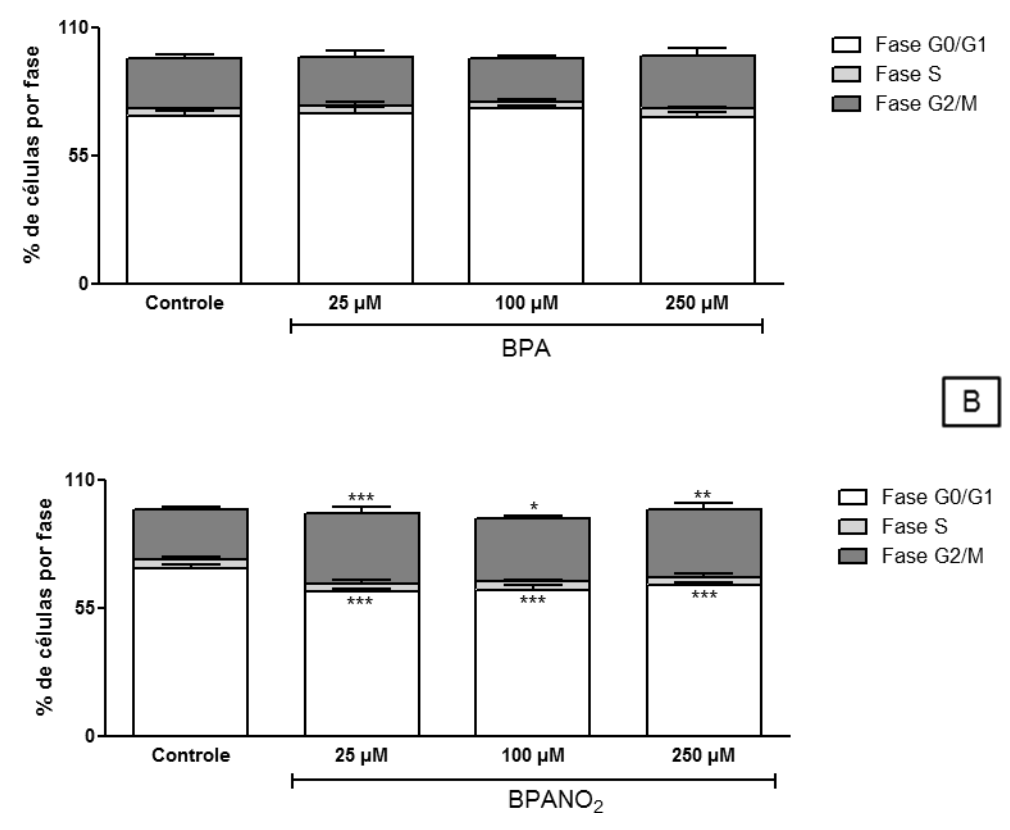

Figura 33 - Ciclo das células MCF-7 avaliado por citometria de fluxo após $24 \mathrm{~h}$ de incubação com as concentrações indicadas de BPA (A) e $\mathrm{BPANO}_{2}$ (B). $\mathrm{N}=4$, média \pm desvio padrão, Kruskal Wallis com pós teste de Dunn, diferenças em relação ao controle. ${ }^{*} P<0.05$; ${ }^{* *} P<0.01$; ${ }^{* *} P<0.001$.

O procedimento de análise do consumo de BPA foi realizado com as células MCF-7 previamente incubadas com 300 nM de bifenila policlorada (PCB126) para indução da atividade de CYP450 1A1. Na Figura 33A são apresentados os dados referentes à análise de atividade de CYP450 1A1 em células MCF-7 incubadas com diferentes concentrações de PCB126 por 24 h, realizando-se o ensaio da etoxirresorufina-O-deetilase (EROD) segundo descrito por Donato e colaboradoresdonato (Donato, Gomez-Lechon et al. 1993). A concentração de 300 nM de PCB126 levou ao aumento da atividade enzimática e foi escolhida para as incubações subsequentes com BPA. Na Figura 33B são apresentados os dados de consumo de BPA pelas células MCF-7. As células foram incubadas com 300 nM de PCB126 por 24 h, o meio 
de cultura foi trocado, e as células incubadas com BPA nas concentrações de $25 \mu \mathrm{M}, 100 \mu \mathrm{M}$ e $250 \mu \mathrm{M}$ por mais $24 \mathrm{~h}$.

A

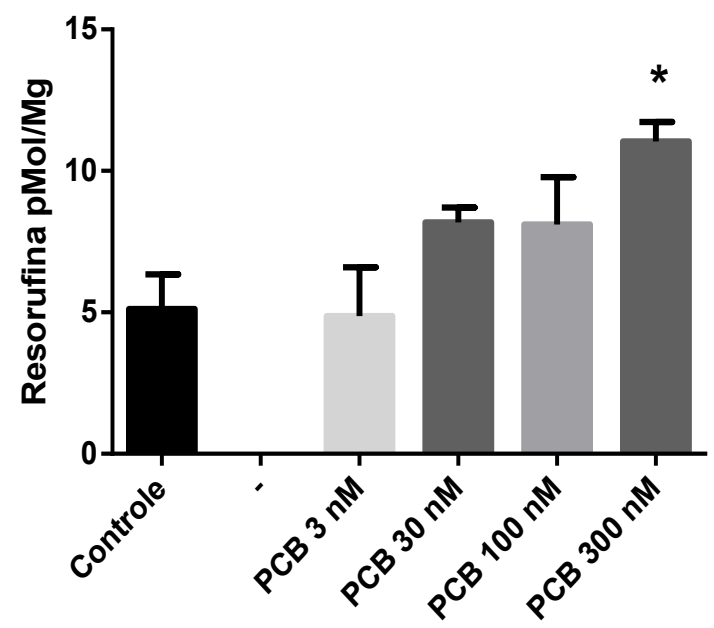

B

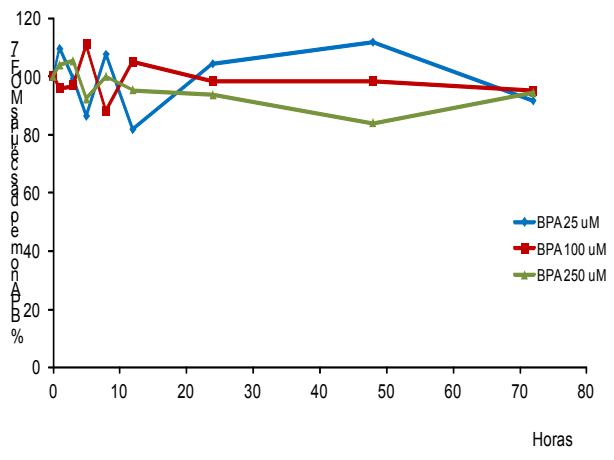

Figura 34 - (A) Atividade etoxirresorufina-O-deetilase das células MCF-7 incubadas com as concentrações indicadas de PCB por $24 \mathrm{~h}$; B) Consumo de BPA pelas células MCF-7. As células foram cultivadas na densidade de $2,4 \times 10^{6}$ células por poço, incubadas com $300 \mathrm{nM}$ de PCB por $24 \mathrm{~h}$ e, após troca do meio de cultura, incubadas com BPA nas concentrações indicadas. Alíquotas do meio de cultura foram retiradas nos tempos indicados para quantificação de BPA por HPLC-DAD $(\lambda=277 \mathrm{~nm})$.

Assim como para as células HL-60, observou-se que a absorção de BPA pelas células MCF-7 é bastante lenta. A quantificação de BPA no meio de cultura das células permitiu verificar que após 72 h de incubação, apenas 5 a $8 \%$ da quantidade de BPA disponível inicialmente havia sido consumida. Não foi possível observar a formação de produtos de biotransformação, mesmo nas células com atividade etoxirresorufina-O-deetilase aumentada após exposição a PCB126.

Foi observada maior resistência das células MCF-7, em comparação com as células HL-60, à citotoxicidade induzida por BPA e $\mathrm{BPANO}_{2}$. Resumidamente, como resultado da exposição das células MCF-7 a BPA, 
houve pequeno aumento da permeabilidade da membrana plasmática (250 $\mu \mathrm{M})$, indução dos níveis de ROS após $24 \mathrm{~h}(25 \mu \mathrm{M})$ e aumento da população de células em sub $\mathrm{G} 1$, ou seja, com DNA fragmentado (250 $\mu \mathrm{M})$, mas sem alteração do ciclo celular. No caso de $\mathrm{BPANO}_{2}$, foi observada parada do ciclo celular em G2/M (25 $\mu \mathrm{M}, 100 \mu \mathrm{M}$ e $250 \mu \mathrm{M})$, assim como aumento de permeabilidade da membrana plasmática após $24 \mathrm{~h}$ de incubação $(25 \mu \mathrm{M}, 250$ $\mu \mathrm{M})$, sem indução de ROS ou aumento de células em sub G1.

A maior resistência das células MCF-7 aos efeitos citotóxicos do BPA está provavelmente relacionada à ação estrogênica desse xenobiótico. BPA se liga aos receptores nucleares de estrógeno $\alpha$ e $\beta(\operatorname{Er} \alpha$ e $\operatorname{Er} \beta)$, modulando a expressão de genes que favorecem a sobrevivência e proliferação celular. Liga-se também ao receptor 30 acoplado à proteína G (GPR30) na membrana plasmática, induzindo rápida sinalização estrogênica via ativação de Erk1/2,

que também favorece a expressão de genes (por exemplo, c-fos, genes sob controle do fator AP-1) relacionados a sobrevivência e proliferação (Dong, Terasaka et al. 2011). Não há informação sobre ação estrogênica do $\mathrm{BPANO}_{2}$, mas as células incubadas com 25, 100 e $250 \mu \mathrm{M}$ dessa molécula apresentaram parada do ciclo em G2/M, o que indica modulação diferente de vias de sinalização em comparação ao BPA.

\subsubsection{Avaliação de efeitos genotóxicos em células MCF-7}

As células MCF-7 foram incubadas com BPA na ausência (Figura 34A) e presença de agonista de receptor Ah (Figura 34B) e o DNA foi extraído para análise das lesões 8-oxodG, CEdG, O6-mdG e BPA-Gua. Foi possível quantificar as lesões 8-oxodG e CEdG, não tendo sido detectadas as demais. 
Foi observado aumento dos níveis de CEdG e 8-oxodG nas células incubadas com BPA $(100 \mu \mathrm{M}, 250 \mu \mathrm{M})$ sem a ativação prévia de receptores Ah (Figura 34A). A ativação dos receptores Ah com PCB126 levou a menor aumento do nível das lesões após as incubações com BPA (Figura 34B). Apesar da resistência à morte nas incubações com BPA, provavelmente por ativação de vias de sinalização que levam à sobrevivência e replicação em detrimento de parada no ciclo e morte, há um estresse oxidativo evidenciado pela indução de lesões no DNA. A sinalização estrogênica juntamente com o aumento dos níveis de lesões no DNA aumenta a chance de mutações e de transformação maligna. O estresse oxidativo não parece estar relacionado à biotransformação do BPA via citocromo P450, podendo ser devido à sua ação direta em receptores celulares e ativação de vias de sinalização.

É reportado que o estresse oxidativo tem papel importante na patogênese do câncer de mama induzido por estrógeno. O receptor Era tem papel proliferativo importante, favorecendo o crescimento tumoral e o estresse oxidativo, enquanto $\operatorname{Er} \beta$ parece reduzir a proliferação induzida por Era e favorecer a diferenciação da glândula mamária (Nadal-Serrano, Sastre-Serra et al. 2012). Células MCF-7 apresentam razão $\operatorname{Er\alpha /Er\beta ~em~torno~de~1,~sendo~}$ considerada alta. Na presença de estrógeno (17ß-estradiol, E2), essas células apresentam aumento da produção de ROS e estresse oxidativo, provavelmente devido a uma resposta inadequada do sistema antioxidante e à indução de disfunção mitocondrial relacionada à razão $\operatorname{Er} \alpha / \operatorname{Er} \beta$. Células com razão $\operatorname{Er\alpha /Er\beta }$ menor (T47D, em torno de 0,1) ou sem Era (MDA-MB-231) apresentam menos ROS e estresse oxidativo na presença de E2 (Nadal-Serrano, Sastre-Serra et al. 2012). 


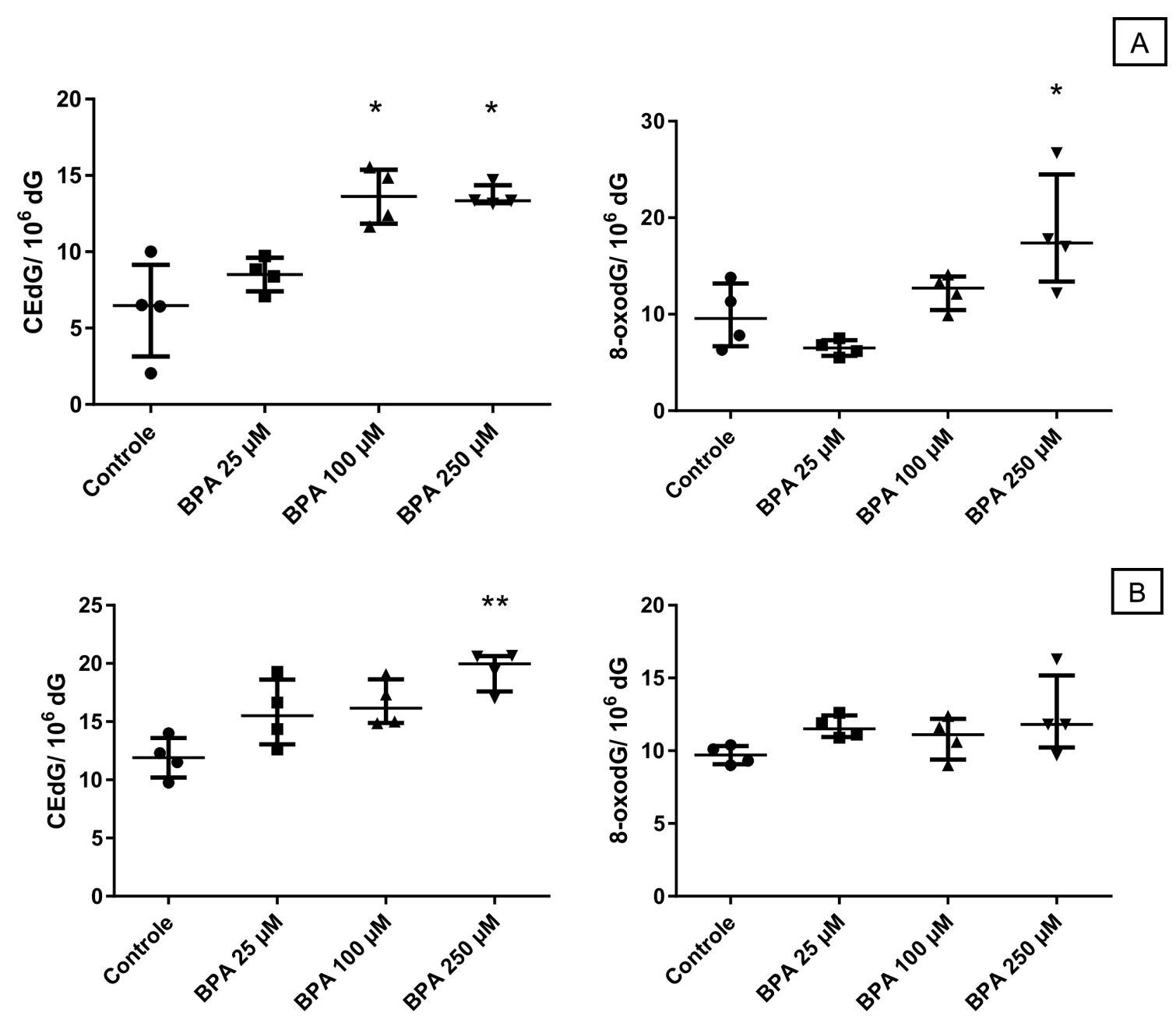

Figura 35 - (A) Níveis de CEdG e 8-oxodG em DNA de células MCF-7 incubadas com BPA nas concentrações indicadas por $24 \mathrm{~h}$. (B) Níveis de CEdG e 8-oxodG em DNA de células MCF-7 incubadas com $300 \mathrm{nM}$ de PCB por $24 \mathrm{~h}$ para aumento da atividade etoxirresorufina-O-deetilase e, após troca do meio de cultura, incubadas com BPA nas concentrações indicadas por $24 \mathrm{~h}$. ${ }^{*} \mathrm{P}<0,05$, ${ }^{* *} \mathrm{P}<0,01$ comparando-se os diferentes grupos com o controle, de acordo com teste de Kruskal Wallis com pós teste de Dunn.

Dentre as lesões analisadas no meio de cultura das células (8-oxodG, $1, N^{2}-\varepsilon d G, 1, N^{6}-\varepsilon d A, C E d G, O^{6}-m d G$ e BPA-Gua), foi novamente possível quantificar CEdG e 8-oxodG, sem detecção das demais. Como apresentado na Figura 35, não houve alteração das concentrações das lesões no meio de cultura. Na ausência de células, o meio de cultura apresentou CEdG na concentração média de $21,3 \pm 7,3$ pg/mL e 8-oxodG na concentração média de 
$10517 \pm 737 \mathrm{pg} / \mathrm{mL}$. Na presença das células, as concentrações de CEdG no meio de cultura aumentaram, enquanto que as de 8-oxodG diminuiram.
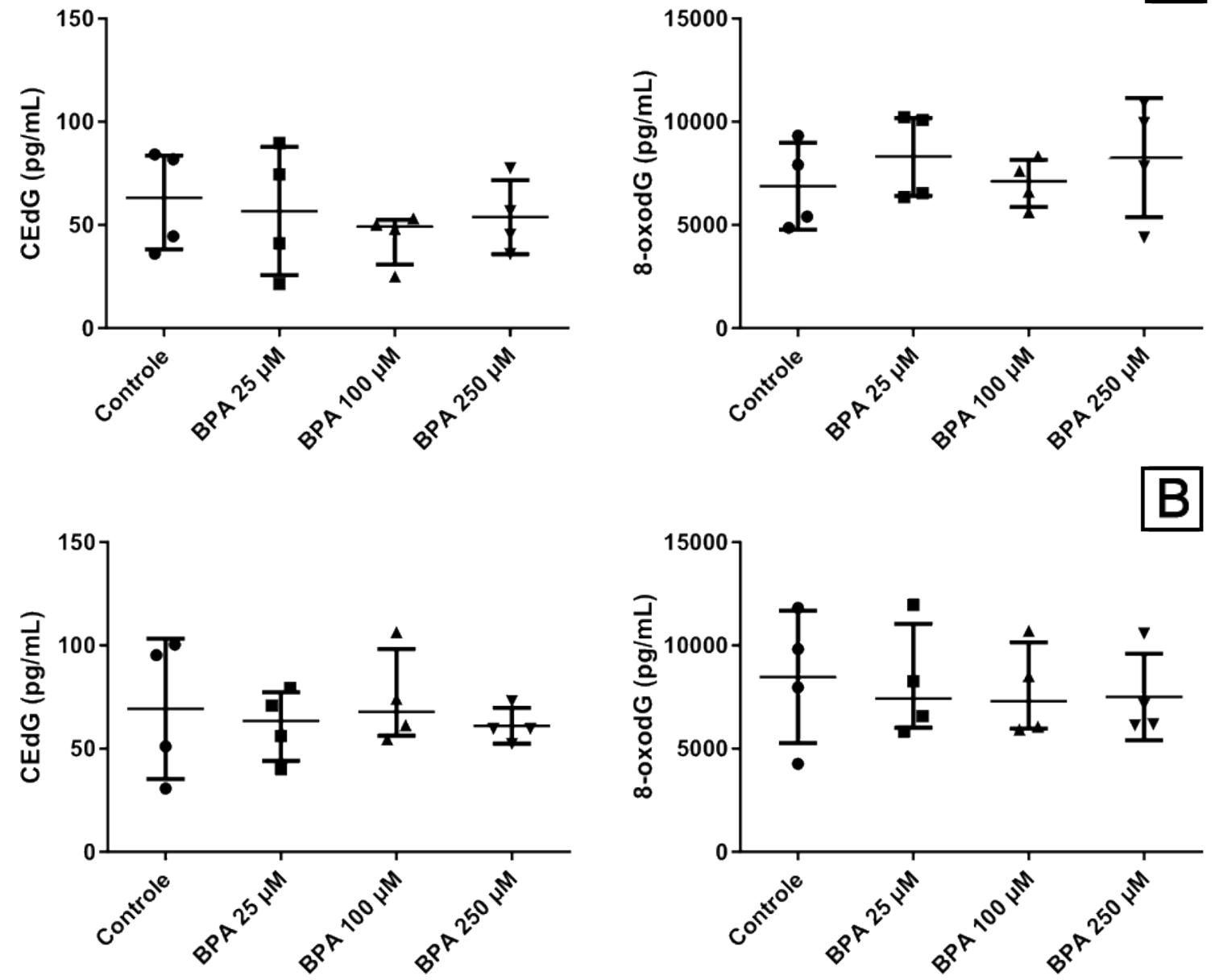

Figura 36 - (A) Níveis de CEdG e 8-oxodG no meio de cultura de células MCF-7 incubadas com BPA. (B) Níveis de CEdG e 8-oxodG no meio de cultura de células MCF-7 incubadas com 300 nM de PCB 126 por $24 \mathrm{~h}$ para aumento da atividade etoxirresorufina-O-deetilase e, após troca do meio de cultura, incubadas com BPA nas concentrações indicadas por $24 \mathrm{~h}$. Análise estatística utilizando o teste de Kruskal Wallis com pós teste de Dunn não mostrou diferença entre os grupos.

No caso das células MCF-7 incubadas com $\mathrm{BPANO}_{2}$, não foi observada indução das lesões CEdG e 8-oxodG no DNA (Figura 36), o que está de acordo com a não observação de aumento dos níveis de ROS nessas incubações. 

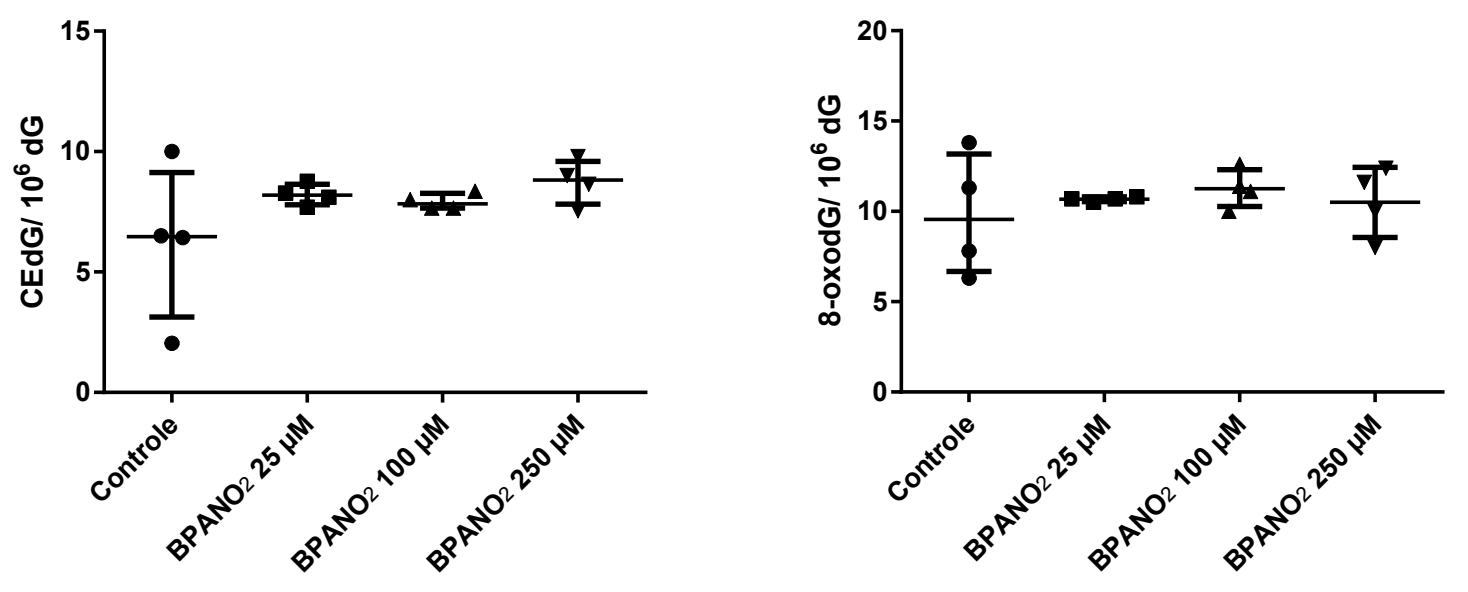

Figura 37 - Níveis de CEdG e 8-oxodG em DNA de células MCF-7 incubadas com $\mathrm{BPANO}_{2}$ nas concentrações indicadas por $24 \mathrm{~h}$. Análise estatística utilizando o teste de Kruskal Wallis com pós teste de Dunn não mostrou diferença entre os grupos

\subsubsection{Avaliação de efeitos epigenéticos em células MCF-7}

Amostras de DNA das células incubadas com BPA, sem e com ativação de citocromo P450 1A1, foram analisadas por HPLC-ESI-MS/MS para quantificação de 5-mdC e 5-hmdC. Os dados apresentados na Figura 37A mostram que no período de $24 \mathrm{~h}$ de incubação não houve alteração dos níveis dessas marcas epigenéticas nas células incubadas com BPA sem ativação de citocromo P450, apesar de ser visível uma tendência de aumento dos níveis de $5-\mathrm{mdC}$.

Entretanto, nas células com ativação de citocromo P450 pelo agonista do receptor Ah (PCB126), foi observado aumento dos níveis de 5-hmdC, sem alteração dos níveis de 5-mdC (Figura 37B). É possível que esse aumento inicial dos níveis de 5-hmdC resulte em queda da metilação do DNA em gerações subsequentes, o que teria que ser avaliado após 48 e $72 \mathrm{~h}$ de incubação. Caso a atividade de DNMTs esteja aumentada nas células expostas a BPA, como sugerido anteriormente com base no trabalho de Chen e 
colaboradores (2014), o aumento dos níveis de 5-hmdC pode ser uma resposta celular na tentativa de manter o padrão de metilação do DNA. Não há dados na literatura sobre alteração do padrão de metilação do DNA de células MCF-7 por BPA e o significado dessas alterações sob exposição a BPA precisa ser melhor avalido.

Observou-se também que as células MCF-7 pré-incubadas com PCB126 apresentaram aumento de aproximadamente 10 vezes nos níveis de 5 -hmdC e níveis ligeiramente mais baixos de 5-mdC em relação às que não foram préincubadas com PCB (comparar níveis dos controles na Figura 37A e B). A influência do PCB nos níveis de 5-hmdC também precisa ser melhor investigada.

Quanto à exposição das células MCF-7 a BPANO 2 , verificou-se aumento dos níveis de 5-mdC, sem alteração dos níveis de 5-hmdC (Figura 37C). 

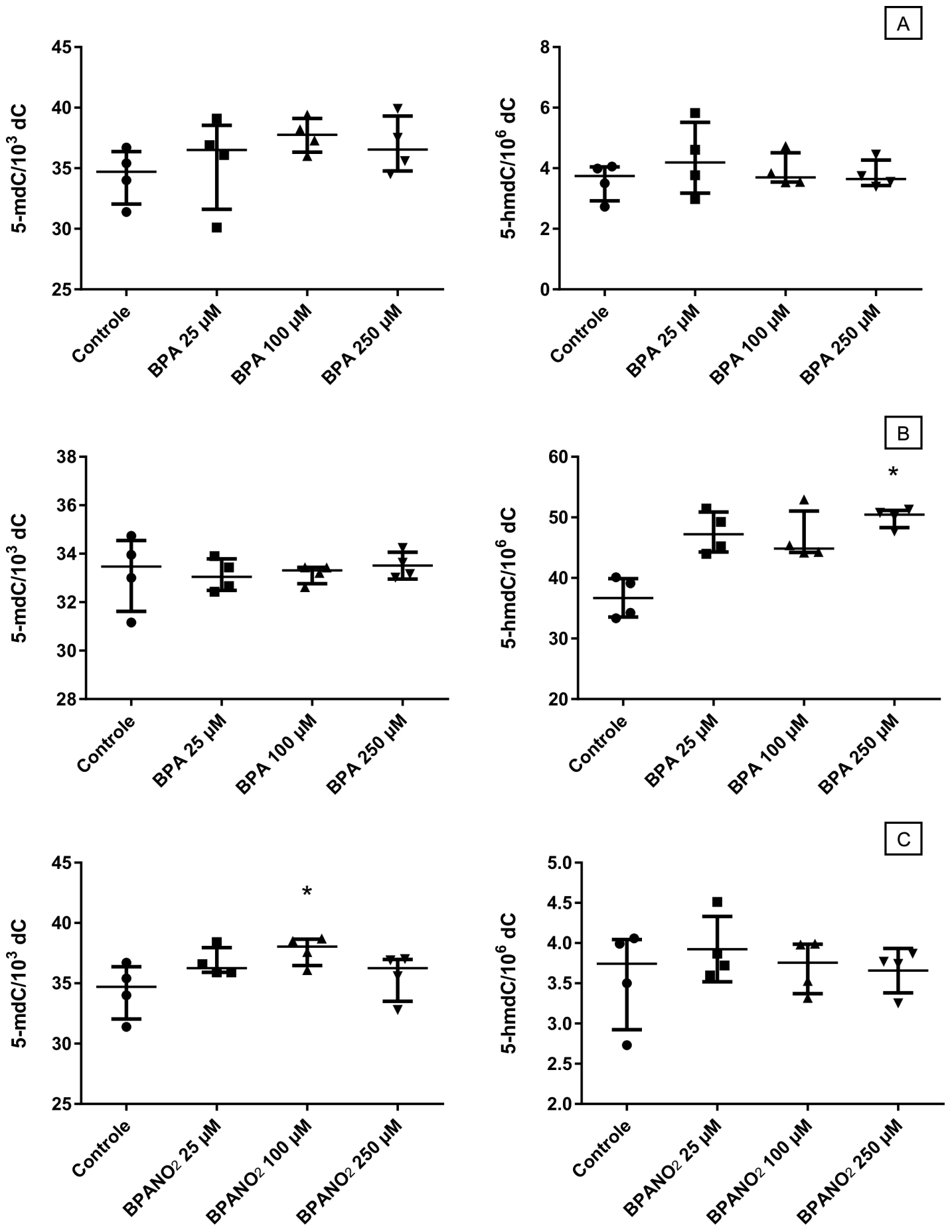

Figura 38 - (A) Níveis de 5-mdC e 5-hmdC em DNA de células MCF-7 incubadas com BPA nas concentrações indicadas por $24 \mathrm{~h}$. (B) Níveis de 5-mdC e 5-hmdC em DNA de células MCF-7 incubadas com $300 \mathrm{nM}$ de PCB por $24 \mathrm{~h}$ para aumento da atividade etoxirresorufina-O-deetilase e, após troca do meio de cultura, incubadas com BPA nas concentrações indicadas por $24 \mathrm{~h}$. (C) Níveis de 5-mdC e 5hmdC em DNA de células MCF-7 incubadas com $\mathrm{BPANO}_{2}$ nas concentrações indicadas por $24 \mathrm{~h}$ * $\mathrm{P}<$ 0,05 comparando-se os diferentes grupos com o controle, de acordo com teste de Kruskal Wallis com pós teste de Dunn. 
4.5. Efeitos tóxicos do BPA em ratos Sprague-Dawley: hemograma, mielograma, adutos de DNA na urina, efeitos genotóxicos e epigenéticos em fígado e rim

\subsubsection{Caracterização do modelo experimental}

Para obtenção de dados in vivo, ratos Sprague-Dawley machos, com $250 \mathrm{~g}$ de peso, receberam BPA diariamente ao longo de 4 semanas $(50 \mathrm{mg} / \mathrm{kg}$ de peso corpóreo, diluído em óleo com 0,1\% de DMSO) por via intra-gástrica (gavagem), na vigência e ausência de diabetes. Na vigência de um processo inflamatório, no caso diabetes, esperava-se que BPA fosse mais facilmente ativado para metabólitos reativos, levando à ocorrência de mais lesões no DNA dos tecidos analisados.

A indução do diabetes foi feita por injeção intravenosa (punção da veia peniana) de estreptozotocina (40 mg/kg p.c.), conforme já padronizado no laboratório. Decorridas 72 horas da injeção de estrepetozotocina, a glicemia dos animais foi aferida e foram considerados diabéticos todos os animais que apresentaram glicemia acima de $250 \mathrm{mg} / \mathrm{dL}$. A glicemia dos animais foi monitorada durante as 4 semanas de estudo, uma vez por semana, no mesmo horário.

Observa-se na figura 38 que os animais que receberam estreptozotocina permaneceram diabéticos durante todo o período de experimentação e que a exposição ao BPA na dose de $50 \mathrm{mg} / \mathrm{Kg}$ de peso corpóreo não alterou a glicemia dos animais sadios nem dos animais diabéticos.

Há relato de que a exposição de camundongos ao BPA $(50 \mu \mathrm{g} / \mathrm{kg}$ de peso corpóreo), por via oral, pelo período de 12 semanas induziu resistência à insulina e intolerância à glicose, além de elevar o nível de interleucinas pró- 
inflamatórias e o peso dos animais (Moon, Jeong et al. 2015), o que não foi observado aqui, apesar da dose maior utilizada. Falência das ilhotas pancreáticas devido a sobrecarga mitocondrial também é descrita no caso da exposição a BPA (Aekplakorn, Chailurkit et al. 2014; Shapiro, Dodds et al. 2015; Song, Chou et al. 2015).

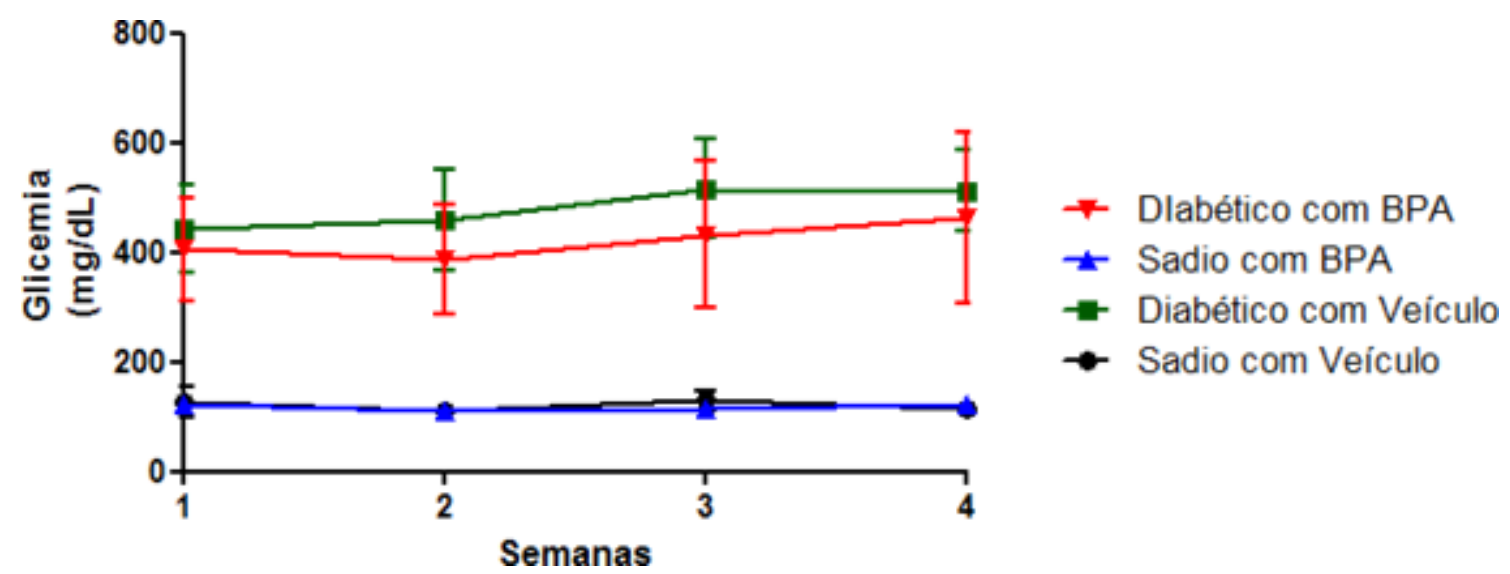

Figura 39 - Perfil glicêmico dos animais expostos ao BPA durante 4 semanas. A glicemia foi verificada a cada semana. Os animais foram considerados diabéticos com glicemia acima de $250 \mathrm{mg} / \mathrm{dL}$. Os resultados expressam a média \pm desvio padrão; os grupos diabéticos com ou sem BPA apresentaram $\mathrm{P}<0,001$, peto teste one way ANOVA, com relação aos animais sadios com e sem BPA.

Quanto ao ganho de peso, observa-se na figura 39 uma tendência a maior ganho de peso dos animais sadios expostos ao BPA, embora sem diferença estatística. É relatado que a exposição ao BPA aumenta a concentração de adiponectina no soro, o que está relacionado ao aumento de peso e à adipogênese (Marmugi, Lasserre et al. 2014; Moon, Jeong et al. 2015). 


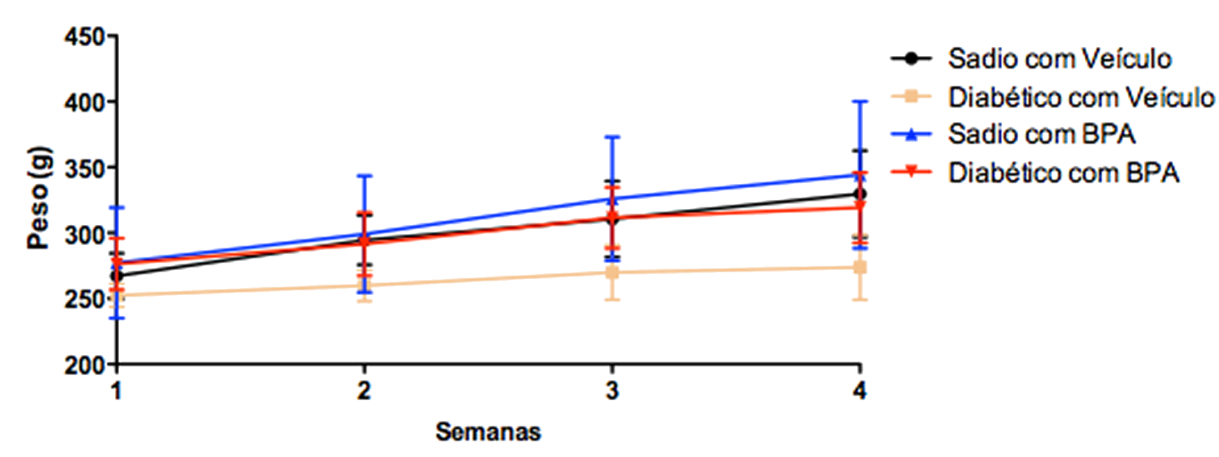

Figura 40 - Perfil do ganho de peso de ratos Sprague-Dawley expostos ao BPA por via intragastrica. Os animais foram expostos durante 4 semanas ao BPA na concentração de $50 \mathrm{mg} / \mathrm{kg}$ de peso corpóreo. Os resultados expressam a média \pm desvio padrão.

\subsubsection{Alterações no hemograma e mielograma}

Com a colaboração do Prof. Dr. Ricardo Ambrósio Fock, Laboratório de Hematologia Experimental da FCF USP, foram obtidos o hemograma e o mielograma dos animais.

Observa-se no hemograma (Figura 40) o aumento do número total de hemácias circulantes e do hematócrito nos animais diabéticos expostos ao BPA. Entretanto, não houve alteração significativa das quantidades dos outros tipos celulares.

$\mathrm{Na}$ medula óssea (Figura 41) observa-se aumento do número de eosinófilos e linfócitos nos animais diabéticos expostos ao BPA, podendo-se sugerir a indução de um estado inflamatório alérgico. Dados da literatura mostram que o BPA induz liberação de histamina, um mediador alérgico, além de aumentar a liberação de interleucinas pró-inflamatórias, como IL-6, que favorece a proliferação celular (Bonds and Midoro-Horiuti 2013; Marmugi, Lasserre et al. 2014; Moon, Jeong et al. 2015).

Os animais não diabéticos expostos ao BPA apresentaram quantidades diminuídas de promielócitos, blastos e bastonetes. Tal efeito do BPA nos 
animais não diabéticos pode ser entendido como precursor de um estado de aplasia de medula, uma vez que há diminuição do número de células mais jovens que, mais tarde, pode resultar em diminuição do número total de células. A não observação do mesmo efeito no sangue deve-se justamente ao fato de a diminuição ocorrer em cascata e não ter havido tempo, no período de 4 semanas, para que a alteração fosse detectada nesse compartimento. Nos animais diabéticos expostos ao BPA esse efeito não foi observado, podendo estar mascarado pelo aumento da produção de células induzido pelo diabetes (Shill, Feinglos et al. 2007; Chao, Song et al. 2010; Wang, Bao et al. 2013; O'Brien, Dolinoy et al. 2014).

A

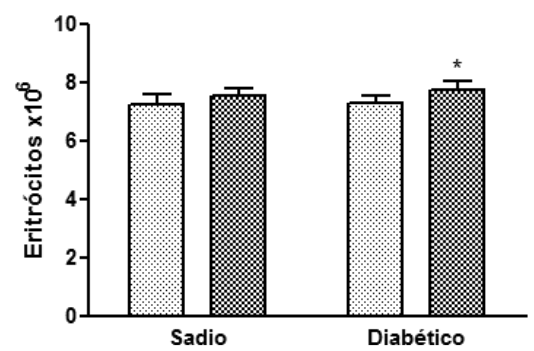

C

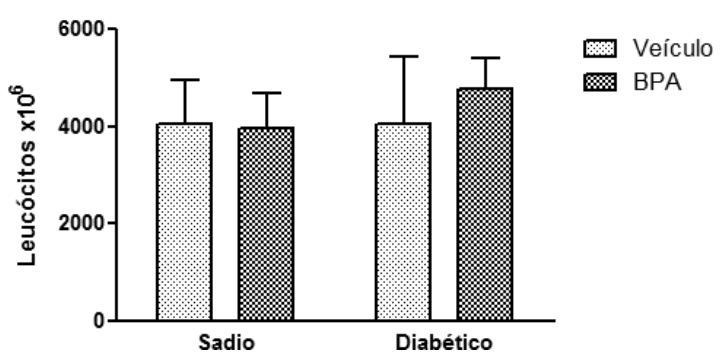

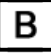

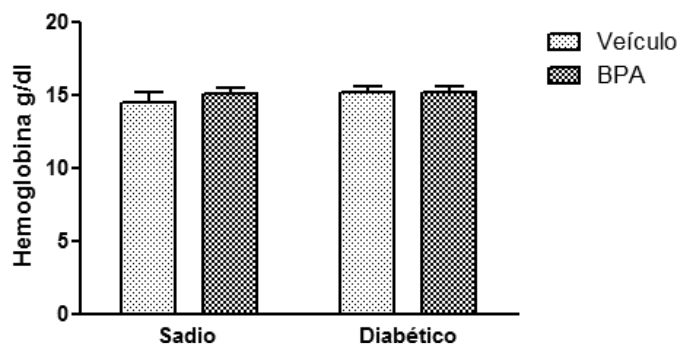

D

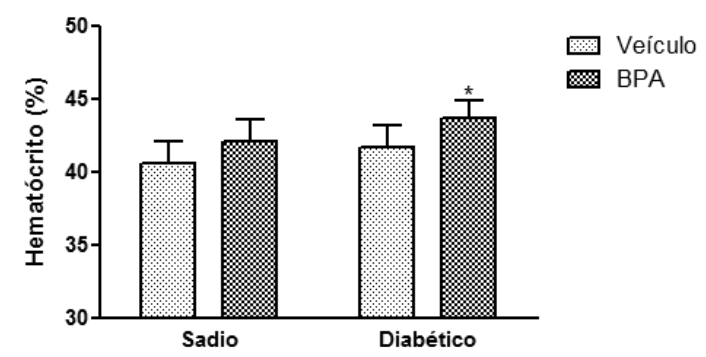

Figura 40 - Legenda na próxima página 


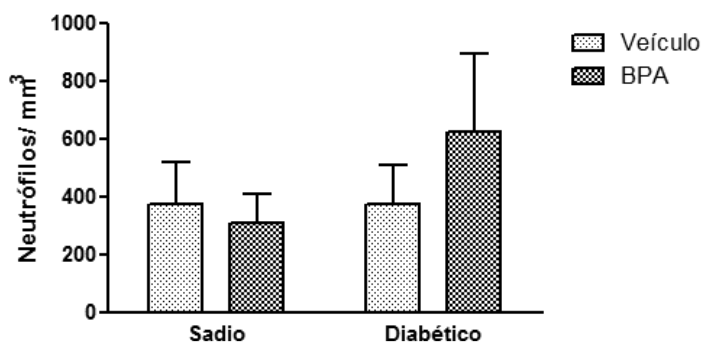

G

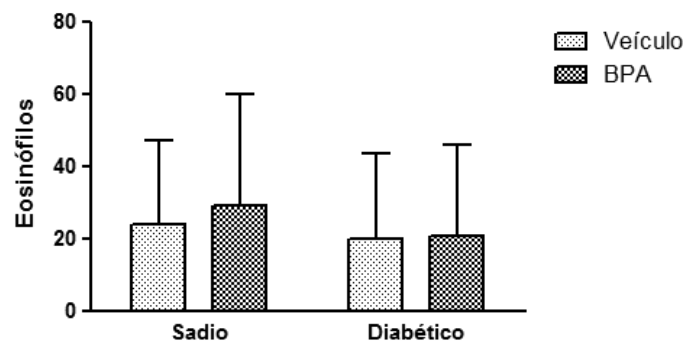

$\mathrm{H}$
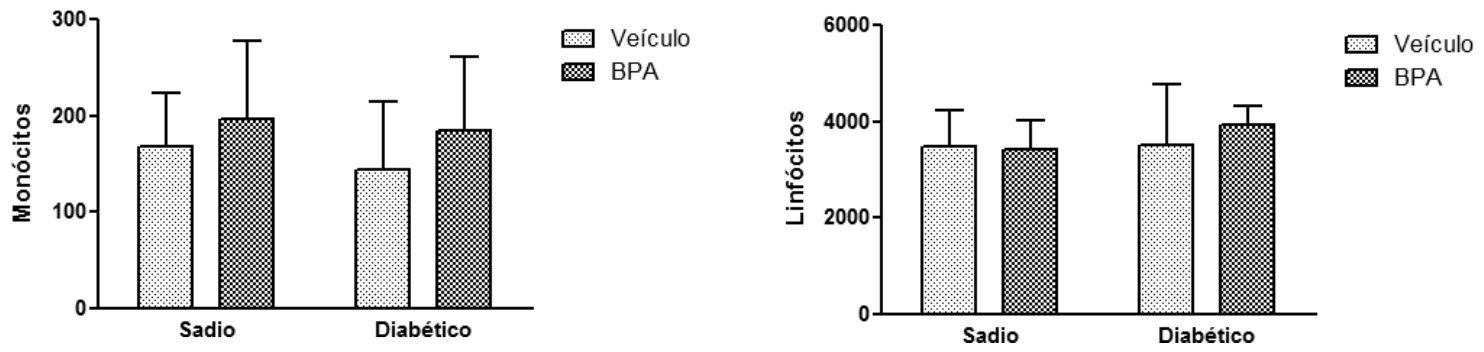

Figura 41 - Hemograma de ratos Sprague-Dawley expostos a BPA (50 mg/kg p.c.) na vigência ou ausência (sadios) de diabetes. (A) eritrócitos circulantes; (B) hemoglobina; (C) leucócitos circulantes; (D) porcentagem do hematócritos. Grupos sadios $(N=5)$, grupos diabéticos $(N=10)$, média \pm desvio padrão, teste $t$ de stundent, diferenças em relação ao respectivo controle (veículo). ${ }^{*} \mathrm{P}<0,05$ 


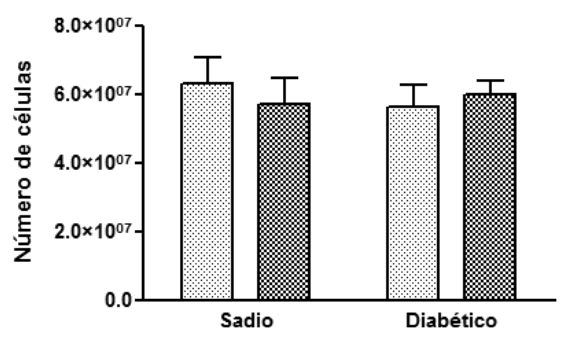

Veículo

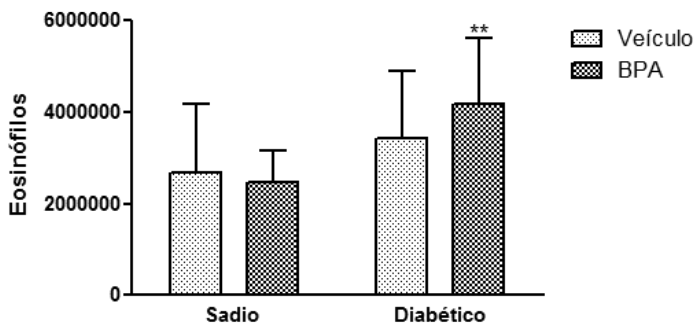

C

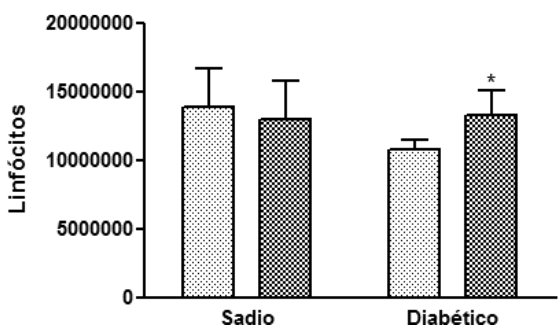

Veículo

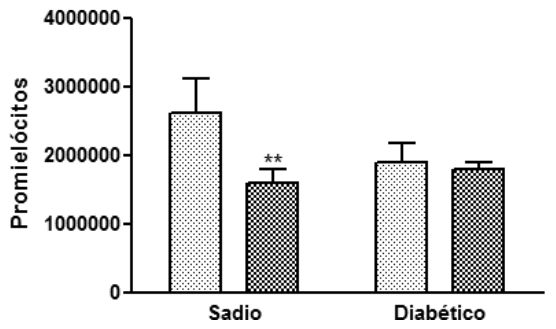

Veículo

BPA

$\mathrm{E}$
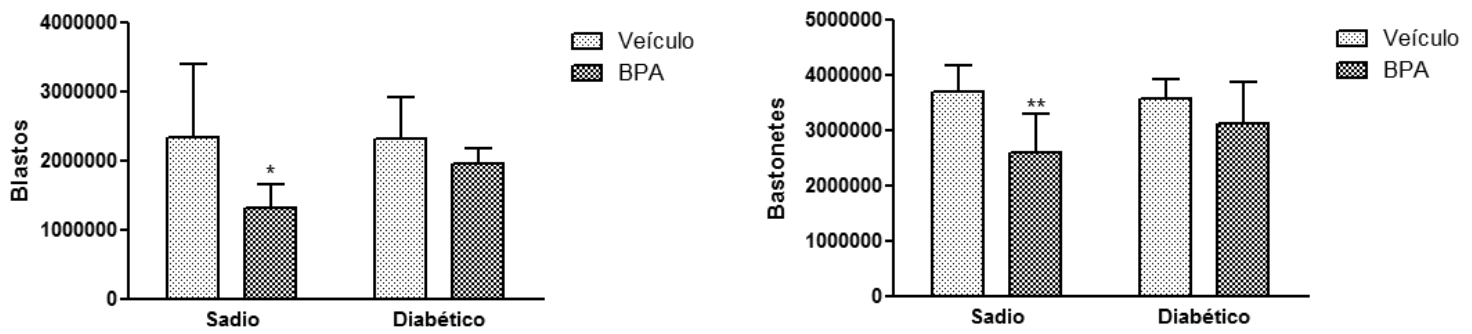

G
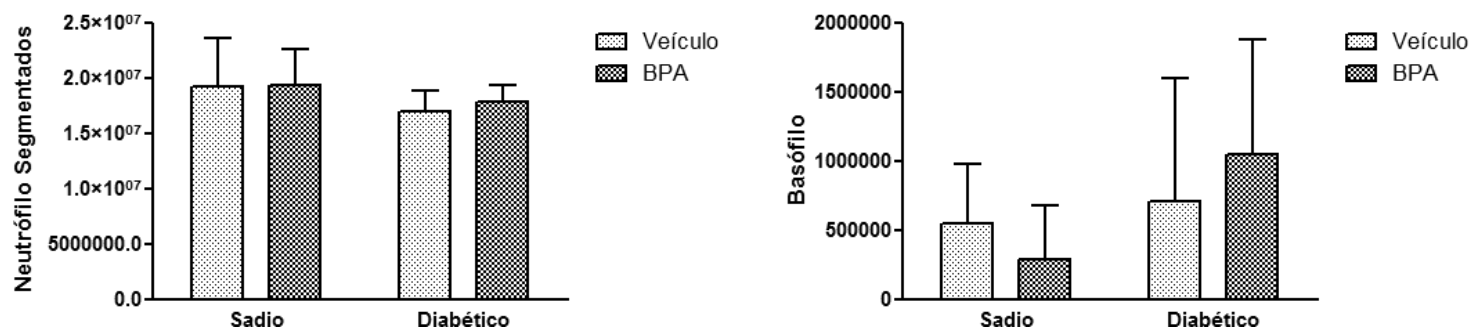

Figura 41 - Legenda na próxima página 

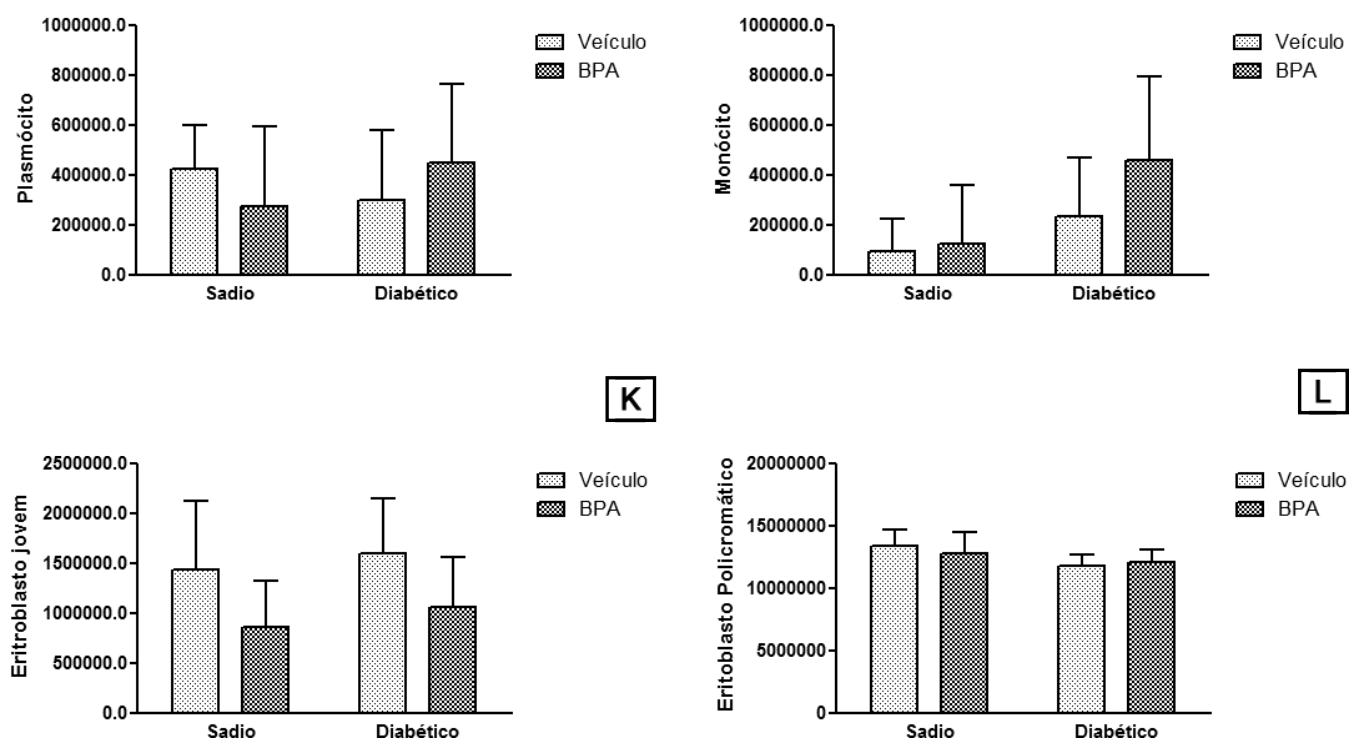

$\mathbf{M}$

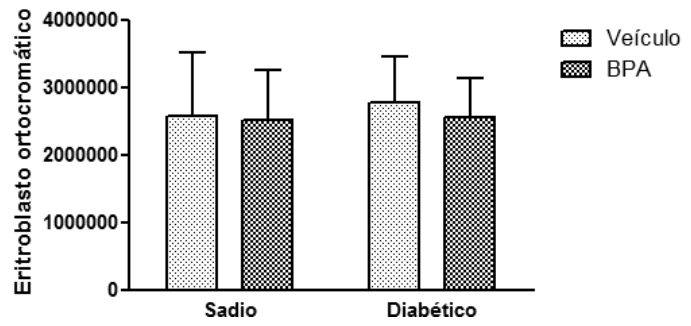

Figura 42 - Mielograma de ratos Sprague-Dawley expostos a BPA (50 mg/kg p.c.) na vigência ou ausência (sadios) de diabetes. (A) número total de células do lavado medular do fêmur; (B) eosinófilos; (C) linfócitos; (D) promielócitos; (E) blastos; (F) bastonetes; (G) segmentados; (H) basófilos; (I) plasmócitos; (J) monócitos; (K) eritroblastos jovens; (L) eritroblastos policromáticos; (M) eritroblastos ortocromáticos. Grupos sadios $(\mathrm{N}=5)$, grupos diabéticos $(\mathrm{N}=10)$, média \pm desvio padrão, teste $t$ de stundent, diferenças em relação ao respectivo controle (veículo). ${ }^{*} \mathrm{P}<0,05,{ }^{* *} \mathrm{P}<0,01$

\subsubsection{Níveis de adutos de DNA na urina}

Uma grande variedade de moléculas de baixo peso molecular excretadas das células de um organismo pode ser encontrada na urina. Lesões reparadas do DNA possuem esse destino, sendo a urina uma matriz importante para a quantificação do conjunto de lesões removidas do DNA de todas as células do organismo em um determinado período (Broedbaek, Siersma et al. 2011). Para a coleta de urina, os animais permaneceram em gaiolas metabólicas pelo período de $10 \mathrm{~h}$. Os dados estão expressos como 
concentração dos adutos $(\mathrm{pg} / \mathrm{mL})$ e quantidade total $(\mathrm{pg})$ no volume coletado de urina ao longo de $10 \mathrm{~h}$. Observa-se na Figura 42 que BPA na dose administrada não induziu estresse oxidativo a ponto de possibilitar a detecção aumentada das diferentes lesões na urina. Em nenhuma amostra de urina foi possível detectar a presença do aduto BPA-Gua, apesar de ser detectado seu padrão interno como indicado na Figura 43.

O estado de diabetes levou ao aumento de excreção das lesões 8oxodG, CEdG e $0^{6}$-mdG na urina. A excreção aumentada de 8-oxodG e CEdG na urina dos animais diabéticos era esperada, devido ao estresse oxidativo e glicação. No caso da $0^{6}$-mdG, é importante considerar que a condição de diabetes foi induzida pela injeção intravenosa de estreptozotocina, que é um agente indutor de $0^{6}$-mdG no DNA. 
A
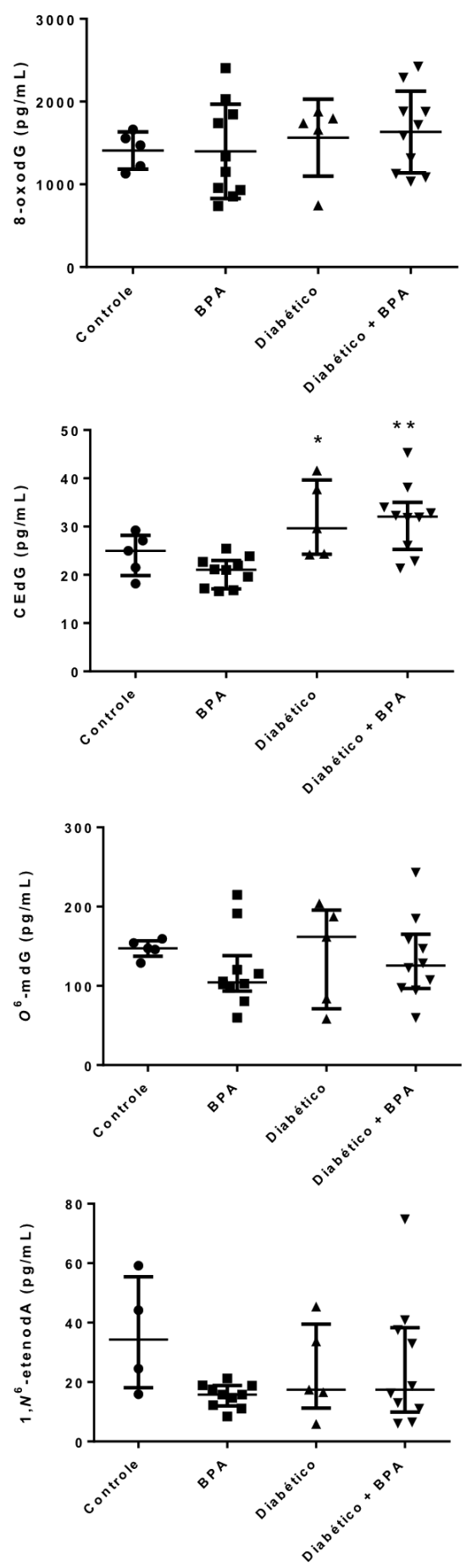

B
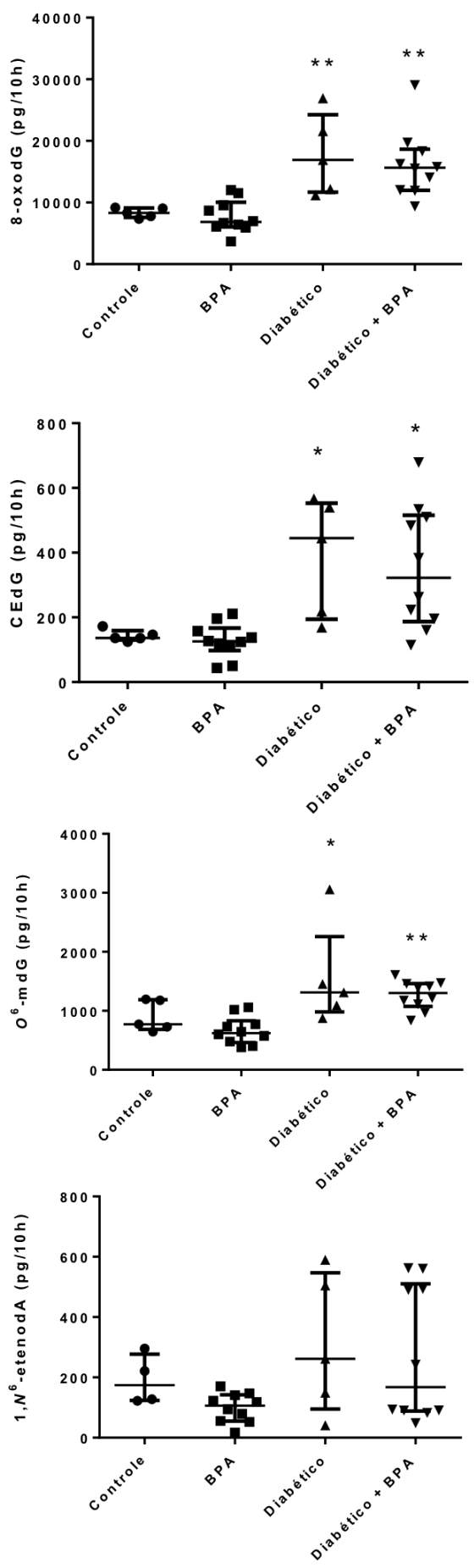

Figura 43 - Níveis de 8-oxodG, CEdG, $O^{6}$-mdG e $1, N^{6} \varepsilon d A$ em urina dos ratos dos diferentes grupos experimentais. A) Concentração na urina de $10 \mathrm{~h}(\mathrm{pg} / \mathrm{mL})$. B) Níveis totais excretados em $10 \mathrm{~h}(\mathrm{pg} / 10 \mathrm{~h})$. ${ }^{*} \mathrm{P}<0,05$, ${ }^{*} \mathrm{P}<0,01$ comparando-se os diferentes grupos com o controle, de acordo com teste de Kruskal Wallis com pós teste de Dunn. 

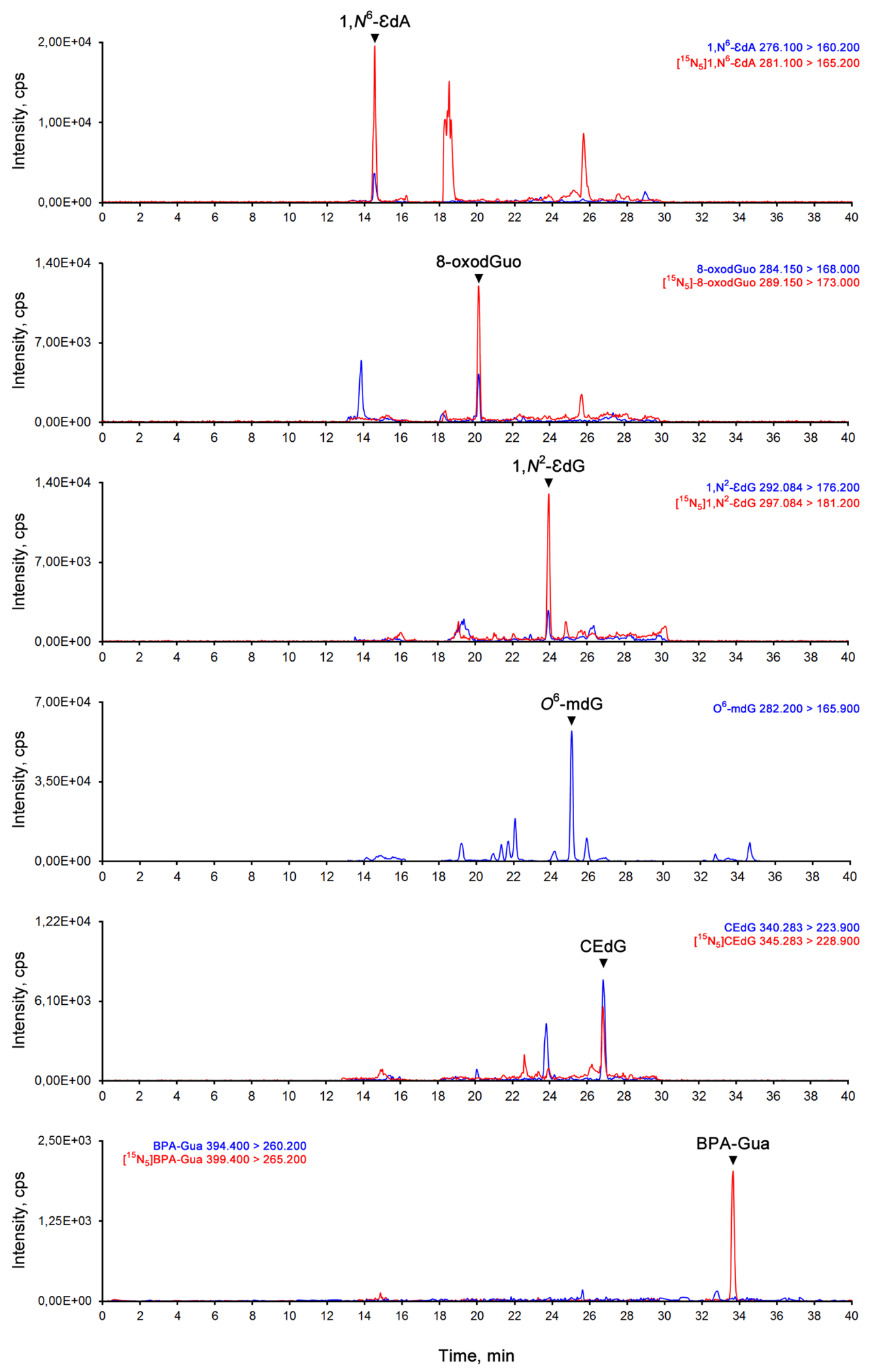

Figura 44 - Cromatogramas obtidos por HPLC-ESI-MS/MS de amostra de urina de rato para quantificação dos adutos indicados. 


\subsubsection{Efeitos genotóxicos e epigenéticos em fígado e rim}

As lesões 8-oxodG, CEdG, $\mathrm{O}^{6}$-mdG e BPA-Gua foram analisadas em amostras de DNA de fígado e rim dos animais. Mais uma vez, o aduto BPAGua não apareceu em nenhuma amostra, mostrando que a via de biotransformação de BPA para BPA-3,4-quinona não deve ser relevante in vivo. As lesões 8-oxodG, CEdG, $\mathrm{O}^{6}$-mdG foram quantificadas e os dados estão apresentados nas Figuras 44 e 45.
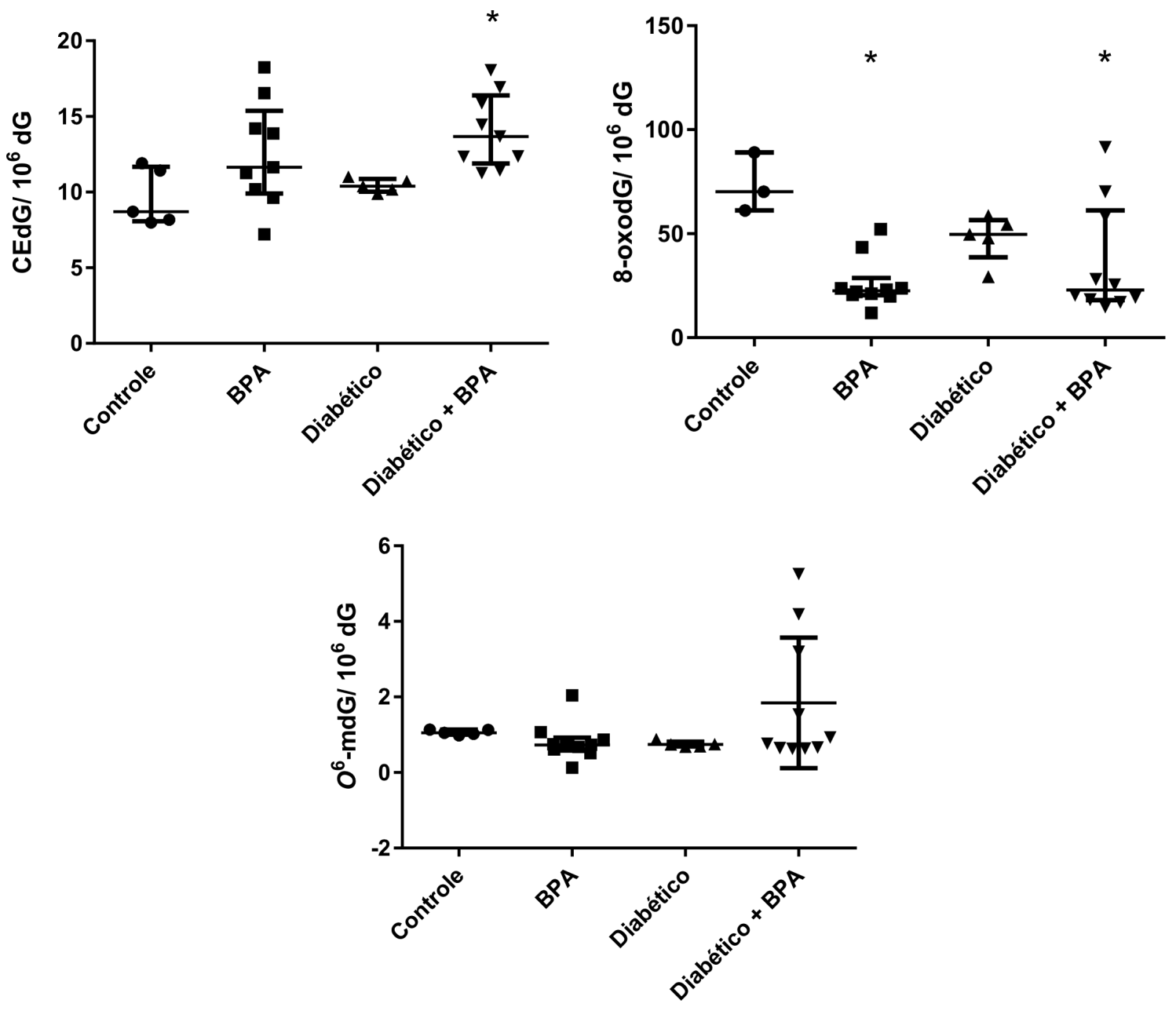

Figura 45 - Níveis de CEdG, 8-oxodG e $0^{6}$-mdG em DNA de fígado dos ratos dos diferentes grupos experimentais. ${ }^{*} \mathrm{P}<0,05$ comparando-se os diferentes grupos com o controle, de acordo com teste de Kruskal Wallis com pós teste de Dunn 

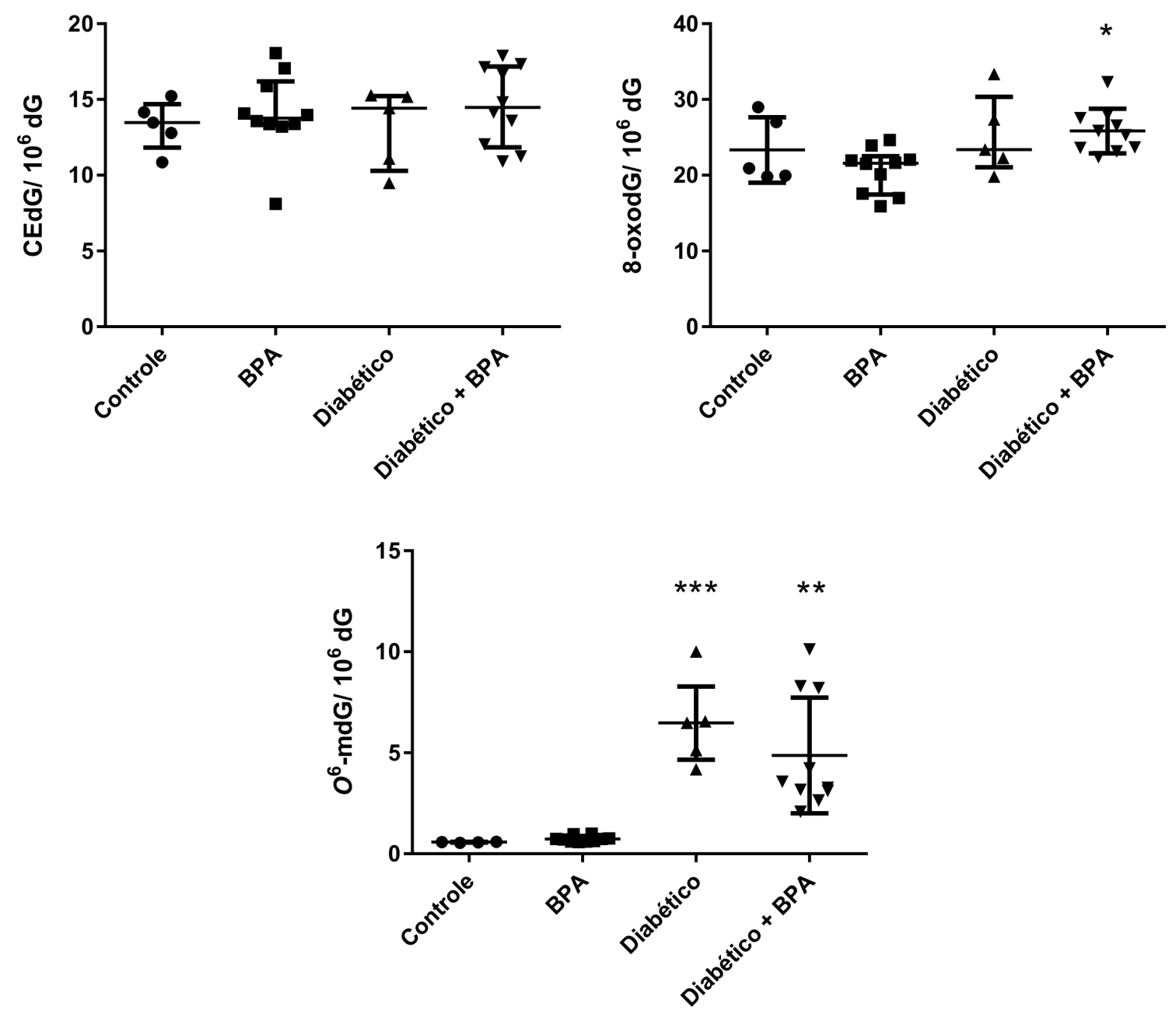

Figura 46 - Níveis de CEdG, 8-oxodG e $0^{6}$-mdG em DNA de rim dos ratos dos diferentes grupos experimentais. ${ }^{*} P<0,05$ em comparação com o grupo BPA, ${ }^{* *} P<0,01$, ${ }^{* * *} P<0,001$ em comparação com o grupo controle, de acordo com teste de Kruskal Wallis com pós teste de Dunn.

Observa-se que a exposição ao BPA levou ao aumento dos níveis de CEdG no fígado dos animais, o que não havia sido ainda verificado na literatura.

Alguns animais diabéticos expostos ao BPA também apresentaram níveis mais elevados de $0^{6}-\mathrm{mdG}$ nesse tecido, mas não houve diferença estatística entre os grupos. É reportada diminuição da atividade da enzima de reparo $0^{6}$-metilguanina DNA metiltransferase em leucócitos de indivíduos diabéticos (Akcay, Dincer et al. 2003), o que favorece a permanência dessa 
lesão mutagênica no DNA. Como citado anteriormente, BPA provoca alterações metabólicas hepáticas que favorecem a metilação de biomoléculas (Chen, Zhou et al. 2014), podendo justificar essa tendência de aumento dos níveis de $0^{6}$-mdG no DNA hepático dos animais diabéticos expostos ao BPA. É importante considerar também que a condição de diabetes foi induzida pela injeção intravenosa de estreptozotocina, que é um agente indutor de $O^{6}$-mdG no DNA. Entretanto, foi decorrido o período de 4 semanas entre a indução de diabetes e a eutanásia dos animais e é descrito que estreptozotocina é seletivamente absorvida pelas células $\beta$ pancreáticas, onde induz toxicidade e leva ao diabetes (Reusser 1971; Baluchnejadmojarad and Roghani 2008)

No caso de 8-oxodG no fígado, as diferenças entre os grupos não devem ser consideradas, uma vez que o nível no grupo controle está anormalmente alto.

Os níveis aumentados de CEdG estão de acordo com o descrito na literatura de que a exposição a BPA leva a estresse oxidativo em diferentes tecidos, como fígado, cérebro, rim, testículos e esperma de camundongos e ratos (Bindhumol et al., 2003; Korkmaz et al., 2010; Chitra et al., 2002; Chitra et al., 2003; Kabuto et al., 2003; Kabuto et al., 2004; De Flora et al., 2011). É possível que as lesões em DNA induzidas por BPA sejam predominantemente devidas a estresse oxidativo, uma vez que não foi detectado o aduto BPA-Gua mesmo na alta dose de BPA administrada.

Nas amostras de DNA de rim foi observado aumento dos níveis de 8oxodG nos animais diabéticos expostos a BPA em comparação com os animais não diabéticos expostos a BPA, além de aumento dos níveis de $0^{6}$-mdG nos animais diabéticos, expostos ou não expostos a BPA, em comparação com os 
respectivos controles (grupo controle e grupo BPA). Não há dados na literatura sobre detecção e quantificação de $0^{6}$-mdG em tecidos na condição de diabetes. Esses níveis aumentados podem estar implicados em complicações do diabetes, como maior risco de câncer.

Na Figura 46 são apresentados os níveis de 5-mdC e 5-hmdC em DNA de fígado dos animais.

Observa-se que os ratos que receberam a dose diária de BPA ao longo de 4 semanas apresentaram aumento dos níveis de 5-mdC e 5-hmdC no DNA. Os dados nos permitem sugerir que a hipermetilação global do DNA observada na exposição ao BPA seja devida à maior atividade de DNMTs e não à inibição do processo de desmetilação (atividade de TET). Alterações dos níveis de metilação e hidroximetilação levam a alterações da expressão gênica que podem culminar em transformação maligna.
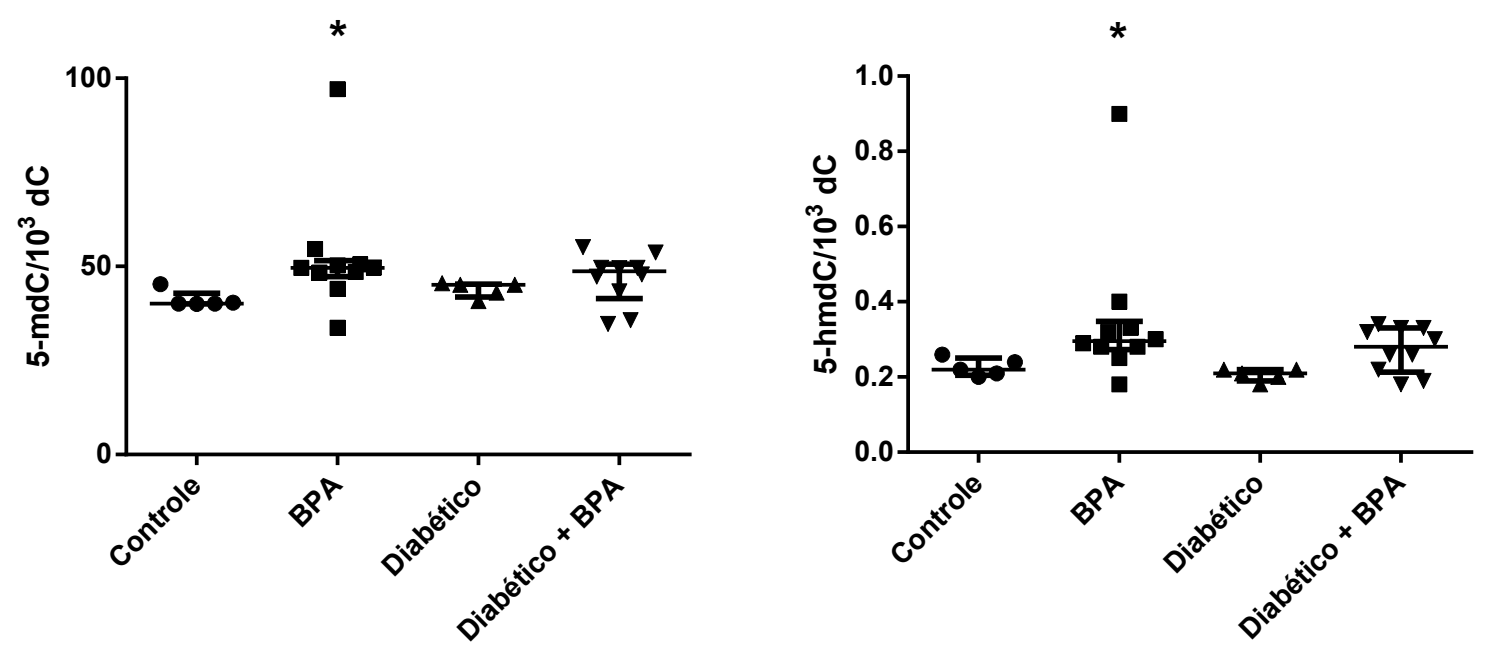

Figura 47 - Níveis de 5-mdC e 5-hmdC em DNA de fígado de ratos dos diferentes grupos experimentais *P $<0,05$ comparando-se os diferentes grupos com o controle, de acordo com teste de Kruskal Wallis com pós teste de Dunn.

As mesmas análises em DNA de rim nos mostraram que BPA não provocou alterações dessas marcas epigenéticas nesse tecido (Figura 47). 

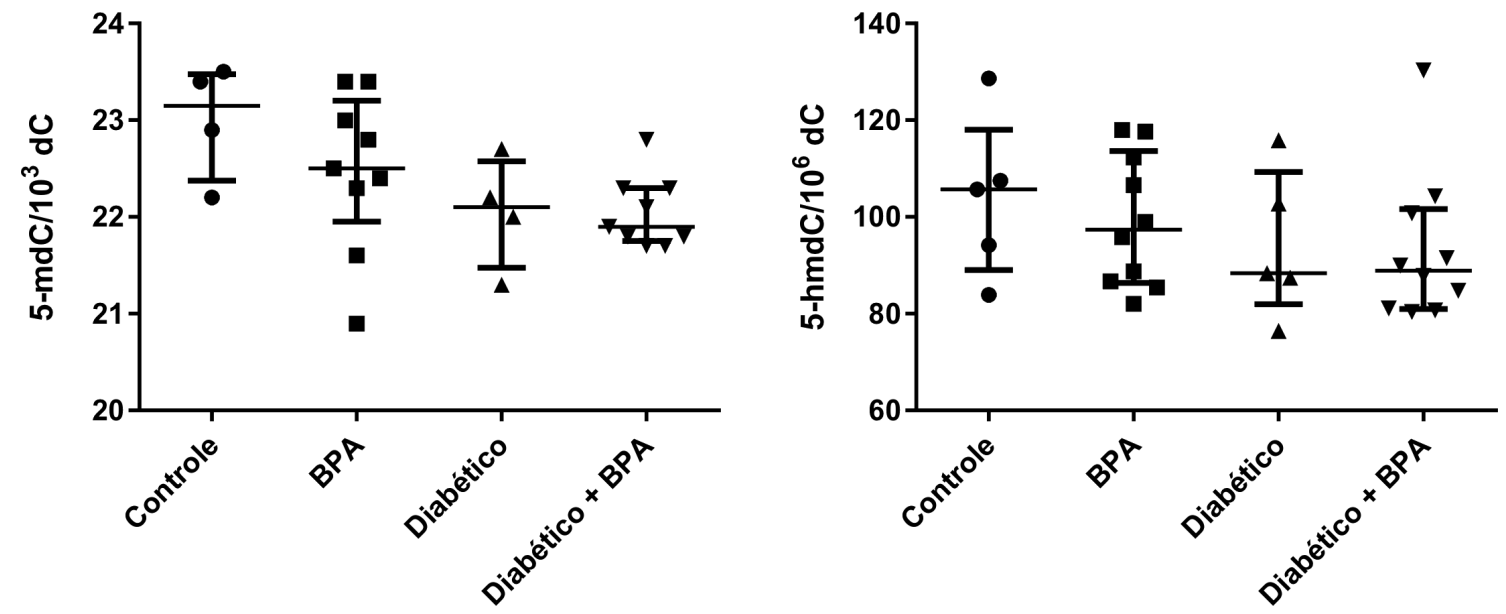

Figura 48 - Níveis de 5-mdC e 5-hmdC em DNA de rim dos ratos dos diferentes grupos experimentais. Análise estatística utilizando o teste de Kruskal Wallis com pós teste de Dunn não mostrou diferença entre os grupos. 
Bancluseño 


\section{Conclusão}

- Os dados obtidos a partir da exposição das células HL-60 a BPA e $\mathrm{BPANO}_{2}$ nos indicam que as duas moléculas provocam alterações metabólicas distintas nesse tipo celular, independentes da via estrogênica, que levam a alterações epigenéticas (BPA) ou genéticas e epigenéticas $\left(\mathrm{BPANO}_{2}\right)$, que podem ter consequências fenotípicas, como progressão maligna, que precisam ser investigadas.

- As células MCF-7 foram mais resistentes que as células HL-60 à citotoxicidade induzida por BPA e $\mathrm{BPANO}_{2}$. Entretanto, observou-se aumento dos níveis de CEdG e 8-oxodG no DNA das células MCF-7 incubadas com BPA sem a ativação prévia de receptores Ah. A ativação dos receptores Ah com PCB126 levou a menor aumento do nível das lesões após as incubações com BPA. A maior resistência das células MCF-7 aos efeitos citotóxicos do BPA está provavelmente relacionada à ação estrogênica desse xenobiótico. A sinalização estrogênica juntamente com o aumento dos níveis de lesões no DNA aumenta a chance de mutações e de transformação maligna. Nas células com ativação do receptor Ah, BPA levou ainda ao aumento da hidroximetilação global, sem alteração da metilação global do DNA.

- Os animais não diabéticos expostos ao BPA apresentaram quantidades diminuídas de promielócitos, blastos e bastonetes na medula óssea (aplasia medular), sem alteração no hemograma. Houve aumento dos níveis de CEdG no fígado, da metilação e hidroximetilação global do DNA hepático, e não foi observada alteração das marcas epigenéticas e adutos de DNA no rim ou na urina. 
- Os animais diabéticos expostos ao BPA apresentaram aumento do número de eosinófilos e linfócitos na medula óssea, podendo-se sugerir a indução de um estado inflamatório alérgico, e aumento do número total de hemácias circulantes e do hematócrito. Houve aumento dos níveis de CEdG, da metilação e hidroximetilação global do DNA hepático, aumento dos níveis de 8-oxodG no DNA renal, sem alteração das marcas epigenéticas no rim, e não foi observada alteração dos adutos de DNA na urina.

- Os dados obtidos apontam para a geração de ROS como uma importante via de cito- e genotoxicidade induzidas por BPA. Sua biotransformação para BPA-3,4-quinona nos modelos utilizados parece ter menor importância para os efeitos, uma vez que não foi detectada a lesão BPA-Gua em nenhuma amostra de DNA, meio de cultura das células ou urina dos animais. Alterações metabólicas induzidas por BPA e ROS podem favorecer as alterações das marcas epigenéticas observadas no DNA das células HL-60, MCF-7 e fígado dos animais. Todas essas alterações podem contribuir para a transformação maligna de células expostas ao BPA. 


\section{Referências}

(2008). "Bisphenol A (BPA) in plastic bottles and metal cans--how dangerous?" Child Health Alert 26: 1-2.

Aekplakorn, W., L. O. Chailurkit and B. Ongphiphadhanakul (2014). "Relationship of serum bisphenol A with diabetes in the Thai population, National Health Examination Survey IV, 2009." J Diabetes.

Akcay, T., Y. Dincer, N. Celebi and H. Ilkova (2003). "O(6)-methylguanine DNA methyltransferase activity in diabetic patients." Diabetes Res Clin Pract 61(1): 1-6.

Alonso-Magdalena, P., E. Vieira, S. Soriano, L. Menes, D. Burks, I. Quesada and A. Nadal (2010). "Bisphenol A exposure during pregnancy disrupts glucose homeostasis in mothers and adult male offspring." Environ Health Perspect 118(9): 1243-1250.

American Dental Association Council on Scientific, A. (2014). "Determination of bisphenol a released from resin-based composite dental restoratives." J Am Dent Assoc 145(7): 763-765. Atkinson, A. and D. Roy (1995). "In vitro conversion of environmental estrogenic chemical bisphenol A to DNA binding metabolite(s)." Biochem Biophys Res Commun 210(2): 424-433. Atkinson, A. and D. Roy (1995). "In vivo DNA adduct formation by bisphenol A." Environmental and Molecular Mutagenesis 26(1): 60-66.

Babu, S., N. A. Vellore, A. V. Kasibotla, H. J. Dwayne, M. A. Stubblefield and R. M. Uppu (2012). "Molecular docking of bisphenol $\mathrm{A}$ and its nitrated and chlorinated metabolites onto human estrogen-related receptor-gamma." Biochem Biophys Res Commun 426(2): 215-220.

Baluchnejadmojarad, T. and M. Roghani (2008). "Chronic administration of genistein improves aortic reactivity of streptozotocin-diabetic rats: mode of action." Vascul Pharmacol 49(1): 1-5.

Ben-Jonathan, N. and R. Steinmetz (1998). "Xenoestrogens: the emerging story of bisphenol a." Trends Endocrinol Metab 9(3): 124-128.

Bennetts, L. E., G. N. De luliis, B. Nixon, M. Kime, K. Zelski, C. M. McVicar, S. E. Lewis and R. J. Aitken (2008). "Impact of estrogenic compounds on DNA integrity in human spermatozoa: evidence for cross-linking and redox cycling activities." Mutat Res 641(1-2): 1-11.

Bhan, A., I. Hussain, K. I. Ansari, S. A. Bobzean, L. I. Perrotti and S. S. Mandal (2014). "Histone methyltransferase EZH2 is transcriptionally induced by estradiol as well as estrogenic endocrine disruptors bisphenol-A and diethylstilbestrol." J Mol Biol 426(20): 3426-3441. Bindhumol, V., K. C. Chitra and P. P. Mathur (2003). "Bisphenol A induces reactive oxygen species generation in the liver of male rats." Toxicology 188(2-3): 117-124.

Bittner, G. D., M. S. Denison, C. Z. Yang, M. A. Stoner and G. He (2015). "Chemicals having estrogenic activity can be released from some bisphenol a-free, hard and clear, thermoplastic resins." Environ Health 14(1): 103.

Bonds, R. S. and T. Midoro-Horiuti (2013). "Estrogen effects in allergy and asthma." Current Opinion in Allergy and Clinical Immunology 13(1): 92-99.

Bontempo, P., L. Mita, A. Doto, M. Miceli, A. Nebbioso, I. Lepore, G. Franci, R. Menafra, V. Carafa, M. Conte, F. De Bellis, F. Manzo, V. Di Cerbo, R. Benedetti, L. D'Amato, M. Marino, A. Bolli, G. Del Pozzo, N. Diano, M. Portaccio, G. D. Mita, M. T. Vietri, M. Cioffi, E. Nola, C.

Dell'aversana, V. Sica, A. M. Molinari and L. Altucci (2009). "Molecular analysis of the apoptotic effects of BPA in acute myeloid leukemia cells." J Transl Med 7: 48.

Breyer, V., M. Frischmann, C. Bidmon, A. Schemm, K. Schiebel and M. Pischetsrieder (2008). "Analysis and biological relevance of advanced glycation end-products of DNA in eukaryotic cells." FEBS J 275(5): 914-925.

Broedbaek, K., V. Siersma, T. Henriksen, A. Weimann, M. Petersen, J. T. Andersen, E. JimenezSolem, E. S. Stovgaard, L. J. Hansen, J. E. Henriksen, S. J. Bonnema, F. Olivarius Nde and H. E. Poulsen (2011). "Urinary markers of nucleic acid oxidation and long-term mortality of newly diagnosed type 2 diabetic patients." Diabetes Care 34(12): 2594-2596. 
Calafat, A. M., Z. Kuklenyik, J. A. Reidy, S. P. Caudill, J. Ekong and L. L. Needham (2005). "Urinary concentrations of bisphenol A and 4-nonylphenol in a human reference population." Environ Health Perspect 113(4): 391-395.

Cao, H., Y. Jiang and Y. Wang (2007). "Stereospecific synthesis and characterization of oligodeoxyribonucleotides containing an N2-(1-carboxyethyl)-2'-deoxyguanosine." J Am Chem Soc 129(40): 12123-12130.

Cao, X. L., J. Corriveau and S. Popovic (2009). "Levels of bisphenol A in canned soft drink products in Canadian markets." J Agric Food Chem 57(4): 1307-1311.

Cavalieri, E. L. and E. G. Rogan (2010). "Is bisphenol A a weak carcinogen like the natural estrogens and diethylstilbestrol?" IUBMB Life 62(10): 746-751.

Chao, C., Y. Song, N. Cook, C. H. Tseng, J. E. Manson, C. Eaton, K. L. Margolis, B. Rodriguez, L. S. Phillips, L. F. Tinker and S. Liu (2010). "The lack of utility of circulating biomarkers of inflammation and endothelial dysfunction for type 2 diabetes risk prediction among postmenopausal women: the Women's Health Initiative Observational Study." Archives of Internal Medicine 170(17): 1557-1565.

Chen, M., K. Zhou, X. Chen, S. Qiao, Y. Hu, B. Xu, B. Xu, X. Han, R. Tang, Z. Mao, C. Dong, D. Wu, Y. Wang, S. Wang, Z. Zhou, Y. Xia and X. Wang (2014). "Metabolomic analysis reveals metabolic changes caused by bisphenol A in rats." Toxicol Sci 138(2): 256-267.

Chepelev, N. L., M. I. Enikanolaiye, L. L. Chepelev, A. Almohaisen, Q. Chen, K. A. Scoggan, M. C. Coughlan, X. L. Cao, X. Jin and W. G. Willmore (2013). "Bisphenol A activates the Nrf1/2antioxidant response element pathway in HEK 293 cells." Chem Res Toxicol 26(3): 498-506. Chia, N., L. Wang, X. Lu, M. C. Senut, C. Brenner and D. M. Ruden (2011). "Hypothesis: environmental regulation of 5-hydroxymethylcytosine by oxidative stress." Epigenetics 6(7): 853-856.

Chitra, K. C., C. Latchoumycandane and P. P. Mathur (2002). "Effect of nonylphenol on the antioxidant system in epididymal sperm of rats." Arch Toxicol 76(9): 545-551.

Chitra, K. C., K. R. Rao and P. P. Mathur (2003). "Effect of bisphenol A and co-administration of bisphenol A and vitamin $\mathrm{C}$ on epididymis of adult rats: a histological and biochemical study."

Asian J Androl 5(3): 203-208.

Chiu, J. and I. W. Dawes (2012). "Redox control of cell proliferation." Trends Cell Biol 22(11): 592-601.

Dahl, C., K. Gronbaek and P. Guldberg (2011). "Advances in DNA methylation: 5hydroxymethylcytosine revisited." Clin Chim Acta 412(11-12): 831-836.

Davis, S. and R. G. Burns (1990). "Decolorization of Phenolic Effluents by Soluble and Immobilized Phenol Oxidases." Applied Microbiology and Biotechnology 32(6): 721-726.

De Flora, S., R. T. Micale, S. La Maestra, A. Izzotti, F. D'Agostini, A. Camoirano, S. A. Davoli, M. G. Troglio, F. Rizzi, P. Davalli and S. Bettuzzi (2011). "Upregulation of clusterin in prostate and DNA damage in spermatozoa from bisphenol A-treated rats and formation of DNA adducts in cultured human prostatic cells." Toxicol Sci 122(1): 45-51.

De Flora, S., R. T. Micale, S. La Maestra, A. Izzotti, F. D'Agostini, A. Camoirano, S. A. Davoli, M. G. Troglio, F. Rizzi, P. Davalli and S. Bettuzzi (2011). "Upregulation of Clusterin in Prostate and DNA Damage in Spermatozoa from Bisphenol A-Treated Rats, and Formation of DNA Adducts in Cultured Human Prostatic Cells." Toxicol Sci.

Dederer, L., I. S. Sokolova, A. A. Bakhmedova, T. D. Miniker, S. Mel'nik and L. B. Gorbacheva (1995). "[Modulation of the antitumor activity of 1-(4-amino-2-methyl-5-pyrimidinyl)methyl-3(2-chloroethyl)-3-nitrosoure a by O(6)-methyl-2'-deoxyguanosine--a new inhibitor of O(6)alkylguanine-DNA-alkyltransferase]." Biokhimiia 60(9): 1521-1529.

Dekant, W. and W. Volkel (2008). "Human exposure to bisphenol A by biomonitoring: methods, results and assessment of environmental exposures." Toxicol Appl Pharmacol 228(1): 114-134. 
Donato, M. T., M. J. Gomez-Lechon and J. V. Castell (1993). "A microassay for measuring cytochrome P450IA1 and P450IIB1 activities in intact human and rat hepatocytes cultured on 96-well plates." Anal Biochem 213(1): 29-33.

Dong, S., S. Terasaka and R. Kiyama (2011). "Bisphenol A induces a rapid activation of Erk1/2 through GPR30 in human breast cancer cells." Environ Pollut 159(1): 212-218.

Edmonds, J. S., M. Nomachi, M. Terasaki, M. Morita, B. W. Skelton and A. H. White (2004). "The reaction of bisphenol A 3,4-quinone with DNA." Biochem Biophys Res Commun 319(2): 556-561.

Ehlert, K. A., C. W. E. Beumer and M. C. E. Groot (2008). "Migration of bisphenol A into water from polycarbonate baby bottles during microwave heating." Food Additives and Contaminants 25(7): 904-910.

Fasano, E., F. Esposito, G. Scognamiglio, F. Di Francesco, P. Montuori, R. Amodio Cocchieri and T. Cirillo (2015). "Bisphenol A contamination in soft drinks as a risk for children's health in Italy." Food Addit Contam Part A Chem Anal Control Expo Risk Assess 32(7): 1207-1214. Fenichel, P., N. Chevalier and F. Brucker-Davis (2013). "Bisphenol A: an endocrine and metabolic disruptor." Ann Endocrinol (Paris) 74(3): 211-220.

Furtmuller, P. G., M. Zederbauer, W. Jantschko, J. Helm, M. Bogner, C. Jakopitsch and C. Obinger (2006). "Active site structure and catalytic mechanisms of human peroxidases." Archives of Biochemistry and Biophysics 445(2): 199-213.

Galloway, T., R. Cipelli, J. Guralnik, L. Ferrucci, S. Bandinelli, A. M. Corsi, C. Money, P. McCormack and D. Melzer (2010). "Daily Bisphenol A Excretion and Associations with Sex Hormone Concentrations: Results from the InCHIANTI Adult Population Study." Environmental Health Perspectives 118(11): 1603-1608.

Geens, T., D. Aerts, C. Berthot, J. P. Bourguignon, L. Goeyens, P. Lecomte, G. Maghuin-Rogister, A. M. Pironnet, L. Pussemier, M. L. Scippo, J. Van Loco and A. Covaci (2012). "A review of dietary and non-dietary exposure to bisphenol-A." Food Chem Toxicol 50(10): 3725-3740. Goodwin, A. P., J. L. Mynar, Y. Ma, G. R. Fleming and J. M. Frechet (2005). "Synthetic micelle sensitive to IR light via a two-photon process." J Am Chem Soc 127(28): 9952-9953.

Gottschalg, E., G. B. Scott, P. A. Burns and D. E. Shuker (2007). "Potassium diazoacetateinduced p53 mutations in vitro in relation to formation of 06-carboxymethyl- and 06-methyl2'-deoxyguanosine DNA adducts: relevance for gastrointestinal cancer." Carcinogenesis 28(2): 356-362.

Groff, T. (2010). "Bisphenol A: invisible pollution." Curr Opin Pediatr 22(4): 524-529.

Gu, Z., T. Nakamura and S. A. Lipton (2010). "Redox reactions induced by nitrosative stress mediate protein misfolding and mitochondrial dysfunction in neurodegenerative diseases." Mol Neurobiol 41(2-3): 55-72.

Hampton, M. B., A. J. Kettle and C. C. Winterbourn (1998). "Inside the neutrophil phagosome: oxidants, myeloperoxidase, and bacterial killing." Blood 92(9): 3007-3017.

Hansson, M., I. Olsson and W. M. Nauseef (2006). "Biosynthesis, processing, and sorting of human myeloperoxidase." Arch Biochem Biophys 445(2): 214-224.

Hassan, Z. K., M. A. Elobeid, P. Virk, S. A. Omer, M. ElAmin, M. H. Daghestani and E. M. AlOlayan (2012). "Bisphenol A Induces Hepatotoxicity through Oxidative Stress in Rat Model." Oxidative Medicine and Cellular Longevity.

Hassold, T. and P. Hunt (2001). "To ERR (meiotically) is human: The genesis of human aneuploidy." Nature Reviews Genetics 2(4): 280-291.

Herath, C. B., W. Jin, G. Watanabe, K. Arai, A. K. Suzuki and K. Taya (2004). "Adverse effects of environmental toxicants, octylphenol and bisphenol $A$, on male reproductive functions in pubertal rats." Endocrine 25(2): 163-172.

Hiroi, H., O. Tsutsumi, M. Momoeda, Y. Takai, Y. Osuga and Y. Taketani (1999). "Differential interactions of bisphenol $A$ and 17 beta-estradiol with estrogen receptor alpha (ERalpha) and ERbeta." Endocrine Journal 46(6): 773-778. 
Hulak, M., I. Gazo, A. Shaliutina and P. Linhartova (2013). "In vitro effects of bisphenol A on the quality parameters, oxidative stress, DNA integrity and adenosine triphosphate content in sterlet (Acipenser ruthenus) spermatozoa." Comp Biochem Physiol C Toxicol Pharmacol 158(2): 64-71.

Hunt, P. A., K. E. Koehler, M. Susiarjo, C. A. Hodges, A. Ilagan, R. C. Voigt, S. Thomas, B. F. Thomas and T. J. Hassold (2003). "Bisphenol a exposure causes meiotic aneuploidy in the female mouse." Curr Biol 13(7): 546-553.

Ito, S., A. C. D'Alessio, O. V. Taranova, K. Hong, L. C. Sowers and Y. Zhang (2010). "Role of Tet proteins in $5 \mathrm{mC}$ to $5 \mathrm{hmC}$ conversion, ES-cell self-renewal and inner cell mass specification." Nature 466(7310): 1129-1133.

Izzotti, A., S. Kanitz, F. D'Agostini, A. Camoirano and S. De Flora (2009). "Formation of adducts by bisphenol $A$, an endocrine disruptor, in DNA in vitro and in liver and mammary tissue of mice." Mutat Res 679(1-2): 28-32.

Jaeg, J. P., E. Perdu, L. Dolo, L. Debrauwer, J. P. Cravedi and D. Zalko (2004). "Characterization of new bisphenol a metabolites produced by CD1 mice liver microsomes and S9 fractions." J Agric Food Chem 52(15): 4935-4942.

Jin, S. G., S. Kadam and G. P. Pfeifer (2010). "Examination of the specificity of DNA methylation profiling techniques towards 5-methylcytosine and 5-hydroxymethylcytosine." Nucleic Acids Res 38(11): e125.

Jolanki, R., L. Kanerva and T. Estlander (1995). "Occupational allergic contact dermatitis caused by epoxy diacrylate in ultraviolet-light-cured paint, and bisphenol A in dental composite resin." Contact Dermatitis 33(2): 94-99.

Kabuto, H., M. Amakawa and T. Shishibori (2004). "Exposure to bisphenol A during embryonic/fetal life and infancy increases oxidative injury and causes underdevelopment of the brain and testis in mice." Life Sci 74(24): 2931-2940.

Kabuto, H., S. Hasuike, N. Minagawa and T. Shishibori (2003). "Effects of bisphenol A on the metabolisms of active oxygen species in mouse tissues." Environ Res 93(1): 31-35.

Kang, J. H., Y. Katayama and F. Kondo (2006). "Biodegradation or metabolism of bisphenol A: from microorganisms to mammals." Toxicology 217(2-3): 81-90.

Keri, R. A., S. M. Ho, P. A. Hunt, K. E. Knudsen, A. M. Soto and G. S. Prins (2007). "An evaluation of evidence for the carcinogenic activity of bisphenol A." Reprod Toxicol 24(2): 240-252.

Kim, J. Y. and H. G. Jeong (2003). "Down-regulation of inducible nitric oxide synthase and tumor necrosis factor-alpha expression by bisphenol A via nuclear factor-kappa B inactivation in macrophages." Cancer Letters 196(1): 69-76.

Korkmaz, A., M. A. Ahbab, D. Kolankaya and N. Barlas (2010). "Influence of vitamin C on bisphenol A, nonylphenol and octylphenol induced oxidative damages in liver of male rats." Food Chem Toxicol 48(10): 2865-2871.

Lang, I. A., T. S. Galloway, A. Scarlett, W. E. Henley, M. Depledge, R. B. Wallace and D. Melzer (2008). "Association of urinary bisphenol A concentration with medical disorders and laboratory abnormalities in adults." JAMA 300(11): 1303-1310.

Liehr, J. G. (1990). "Genotoxic effects of estrogens." Mutat Res 238(3): 269-276.

Loganathan, S. N. and K. Kannan (2011). "Occurrence of Bisphenol A in Indoor Dust from Two Locations in the Eastern United States and Implications for Human Exposures." Arch Environ Contam Toxicol.

Loureiro, A. P., W. Zhang, F. Kassie, S. Zhang, P. W. Villalta, M. Wang and S. S. Hecht (2009). "Mass spectrometric analysis of a cyclic 7,8-butanoguanine adduct of $\mathrm{N}$-nitrosopyrrolidine: comparison to other $\mathrm{N}$-nitrosopyrrolidine adducts in rat hepatic DNA." Chem Res Toxicol 22(10): 1728-1735.

Ma, Y., W. Xia, D. Q. Wang, Y. J. Wan, B. Xu, X. Chen, Y. Y. Li and S. Q. Xu (2013). "Hepatic DNA methylation modifications in early development of rats resulting from perinatal BPA exposure contribute to insulin resistance in adulthood." Diabetologia. 
Manfo, F. P., R. Jubendradass, E. A. Nantia, P. F. Moundipa and P. P. Mathur (2014). "Adverse effects of bisphenol A on male reproductive function." Rev Environ Contam Toxicol 228: 57-82. Marmugi, A., F. Lasserre, D. Beuzelin, S. Ducheix, L. Huc, A. Polizzi, M. Chetivaux, T. Pineau, P. Martin, H. Guillou and L. Mselli-Lakhal (2014). "Adverse effects of long-term exposure to bisphenol A during adulthood leading to hyperglycaemia and hypercholesterolemia in mice." Toxicology 325: 133-143.

Masuda, S., Y. Terashima, A. Sano, R. Kuruto, Y. Sugiyama, K. Shimoi, K. Tanji, H. Yoshioka, Y. Terao and N. Kinae (2005). "Changes in the mutagenic and estrogenic activities of bisphenol A upon treatment with nitrite." Mutation Research-Genetic Toxicology and Environmental Mutagenesis 585(1-2): 137-146.

Melzer, D., N. E. Rice, C. Lewis, W. E. Henley and T. S. Galloway (2010). "Association of Urinary Bisphenol A Concentration with Heart Disease: Evidence from NHANES 2003/06." PLoS One 5(1): - .

Mendiola, J., N. Jorgensen, A. M. Andersson, A. M. Calafat, X. Ye, J. B. Redmon, E. Z. Drobnis, C. Wang, A. Sparks, S. W. Thurston, F. Liu and S. H. Swan (2010). "Are environmental levels of bisphenol a associated with reproductive function in fertile men?" Environ Health Perspect 118(9): 1286-1291.

Moon, M. K., I. K. Jeong, T. Jung Oh, H. Y. Ahn, H. H. Kim, Y. J. Park, H. C. Jang and K. S. Park (2015). "Long-term oral exposure to bisphenol A induces glucose intolerance and insulin resistance." J Endocrinol 226(1): 35-42.

Moon, M. K., M. J. Kim, I. K. Jung, Y. D. Koo, H. Y. Ann, K. J. Lee, S. H. Kim, Y. C. Yoon, B. J. Cho, K. S. Park, H. C. Jang and Y. J. Park (2012). "Bisphenol A Impairs Mitochondrial Function in the Liver at Doses below the No Observed Adverse Effect Level." Journal of Korean Medical Science 27(6): 644-652.

Nadal-Serrano, M., J. Sastre-Serra, D. G. Pons, A. M. Miro, J. Oliver and P. Roca (2012). "The ERalpha/ERbeta ratio determines oxidative stress in breast cancer cell lines in response to 17beta-estradiol." J Cell Biochem 113(10): 3178-3185.

Naik, P. and K. K. Vijayalaxmi (2009). "Cytogenetic evaluation for genotoxicity of bisphenol-A in bone marrow cells of Swiss albino mice." Mutat Res 676(1-2): 106-112.

Nomura, H., M. Matoda, S. Okamoto, K. Omatsu, E. Kondo, K. Kato, K. Umayahara and N. Takeshima (2015). "Clinical Characteristics of Non-Squamous Cell Carcinoma of the Vagina." Int J Gynecol Cancer.

O'Brien, E., D. C. Dolinoy and P. Mancuso (2014). "Perinatal bisphenol A exposures increase production of pro-inflammatory mediators in bone marrow-derived mast cells of adult mice." J Immunotoxicol 11(3): 205-212.

Oh, P. S. and K. T. Lim (2008). "Blocking of intracellular ROS production by phytoglycoprotein $(30 \mathrm{kDa})$ causes anti-proliferation in bisphenol A-stimulated Chang liver cells." Journal of Applied Toxicology 28(6): 749-758.

Park, H. S., J. R. Koduru, K. H. Choo and B. Lee (2014). "Activated carbons impregnated with iron oxide nanoparticles for enhanced removal of bisphenol A and natural organic matter." J Hazard Mater 286C: 315-324.

Patterson, A. R., X. Mo, A. Shapiro, K. E. Wernke, T. K. Archer and C. J. Burd (2015). "Sustained Reprogramming of the Estrogen Response Following Chronic Exposure to Endocrine Disruptors." Mol Endocrinol: me20141237.

Popovic, R., E. Martinez-Garcia, E. G. Giannopoulou, Q. Zhang, Q. Zhang, T. Ezponda, M. Y. Shah, Y. Zheng, C. M. Will, E. C. Small, Y. Hua, M. Bulic, Y. Jiang, M. Carrara, R. A. Calogero, W. L. Kath, N. L. Kelleher, J. P. Wang, O. Elemento and J. D. Licht (2014). "Histone methyltransferase MMSET/NSD2 alters EZH2 binding and reprograms the myeloma epigenome through global and focal changes in H3K36 and H3K27 methylation." PLoS Genet 10(9): e1004566. 
Qiu, S. X., R. Z. Yang and M. L. Gross (2004). "Synthesis and liquid chromatography/tandem mass spectrometric characterization of the adducts of bisphenol A o-quinone with glutathione and nucleotide monophosphates." Chem Res Toxicol 17(8): 1038-1046.

Ranciere, F., J. G. Lyons, V. H. Loh, J. Botton, T. Galloway, T. Wang, J. E. Shaw and D. J. Magliano (2015). "Bisphenol A and the risk of cardiometabolic disorders: a systematic review with meta-analysis of the epidemiological evidence." Environ Health 14: 46.

Reed, C. E. and S. E. Fenton (2013). "Exposure to diethylstilbestrol during sensitive life stages: a legacy of heritable health effects." Birth Defects Res C Embryo Today 99(2): 134-146.

Renz, L., C. Volz, D. Michanowicz, K. Ferrar, C. Christian, D. Lenzner and T. El-Hefnawy (2013). "A study of parabens and bisphenol A in surface water and fish brain tissue from the Greater Pittsburgh Area." Ecotoxicology 22(4): 632-641.

Reusser, F. (1971). "Mode of action of streptozotocin." J Bacteriol 105(2): 580-588.

Rogers, J. A., L. Metz and V. W. Yong (2013). "Review: Endocrine disrupting chemicals and immune responses: a focus on bisphenol-A and its potential mechanisms." Mol Immunol 53(4): 421-430.

Roos, W. P. and B. Kaina (2013). "DNA damage-induced cell death: from specific DNA lesions to the DNA damage response and apoptosis." Cancer Lett 332(2): 237-248.

Schecter, A., N. Malik, D. Haffner, S. Smith, T. R. Harris, O. Paepke and L. Birnbaum (2010). "Bisphenol A (BPA) in U.S. food." Environ Sci Technol 44(24): 9425-9430.

Schrader, T. J., I. Langlois, K. Soper and W. Cherry (2002). "Mutagenicity of bisphenol A (4,4'isopropylidenediphenol) in vitro: effects of nitrosylation." Teratog Carcinog Mutagen 22(6): 425-441.

Schug, T. T., A. Janesick, B. Blumberg and J. J. Heindel (2011). "Endocrine disrupting chemicals and disease susceptibility." J Steroid Biochem Mol Biol 127(3-5): 204-215.

Shapiro, G. D., L. Dodds, T. E. Arbuckle, J. Ashley-Martin, W. Fraser, M. Fisher, S. Taback, E. Keely, M. F. Bouchard, P. Monnier, R. Dallaire, A. Morisset and A. S. Ettinger (2015). "Exposure to phthalates, bisphenol $A$ and metals in pregnancy and the association with impaired glucose tolerance and gestational diabetes mellitus: The MIREC study." Environ Int 83: 63-71.

Shill, J. E., M. N. Feinglos and E. C. Suarez (2007). "Gender as moderator of inflammatory markers and risk of type 2 diabetes in apparently healthy subjects." Diabetes 56: A630-A631. Song, Y., E. L. Chou, A. Baecker, N. Y. You, Y. Song, Q. Sun and S. Liu (2015). "EndocrineDisrupting Chemicals, Risk of Type 2 Diabetes, and Diabetes-Related Metabolic Traits: A Systematic Review and Meta-analysis." J Diabetes.

Spink, B. C., M. M. Hussain, B. H. Katz, L. Eisele and D. C. Spink (2003). "Transient induction of cytochromes P450 $1 \mathrm{~A} 1$ and 1B1 in MCF-7 human breast cancer cells by indirubin." Biochem Pharmacol 66(12): 2313-2321.

Stahlhut, R. W., W. V. Welshons and S. H. Swan (2009). "Bisphenol A data in NHANES suggest longer than expected half-life, substantial nonfood exposure, or both." Environ Health Perspect 117(5): 784-789.

Staples, C. A., P. B. Dorn, G. M. Klecka, S. T. O'Block and L. R. Harris (1998). "A review of the environmental fate, effects, and exposures of bisphenol A." Chemosphere 36(10): 2149-2173. Tahiliani, M., K. P. Koh, Y. Shen, W. A. Pastor, H. Bandukwala, Y. Brudno, S. Agarwal, L. M. Iyer, D. R. Liu, L. Aravind and A. Rao (2009). "Conversion of 5-methylcytosine to 5hydroxymethylcytosine in mammalian DNA by MLL partner TET1." Science 324(5929): 930-935. Tamae, D., P. Lim, G. E. Wuenschell and J. Termini (2011). "Mutagenesis and repair induced by the DNA advanced glycation end product N2-1-(carboxyethyl)-2'-deoxyguanosine in human cells." Biochemistry 50(12): 2321-2329.

Terasaka, H., Y. Kadoma, H. Sakagami and S. Fujisawa (2005). "Cytotoxicity and apoptosisinducing activity of bisphenol A and hydroquinone in HL-60 cells." Anticancer Res 25(3B): 22412247.

Thigpen, J. E., K. D. Setchell, G. E. Kissling, J. Locklear, G. F. Caviness, T. Whiteside, S. M. Belcher, N. M. Brown, B. J. Collins, F. B. Lih, K. B. Tomer, E. Padilla-Banks, L. Camacho, F. G. 
Adsit and M. Grant (2013). "The estrogenic content of rodent diets, bedding, cages, and water bottles and its effect on bisphenol a studies." J Am Assoc Lab Anim Sci 52(2): 130-141.

Toyoizumi, T., Y. Deguchi, S. Masuda and N. Kinae (2008). "Genotoxicity and estrogenic activity of 3,3'-dinitrobisphenol A in goldfish." Biosci Biotechnol Biochem 72(8): 2118-2123.

Ulutas, O. K., N. Yildiz, E. Durmaz, M. A. Ahbab, N. Barlas and I. Cok (2011). "An in vivo assessment of the genotoxic potential of bisphenol A and 4-tert-octylphenol in rats." Arch Toxicol 85(8): 995-1001.

Valinluck, V. and L. C. Sowers (2007). "Endogenous cytosine damage products alter the site selectivity of human DNA maintenance methyltransferase DNMT1." Cancer Res 67(3): 946-950. Vandenberg, L. N., T. Colborn, T. B. Hayes, J. J. Heindel, D. R. Jacobs, Jr., D. H. Lee, T. Shioda, A. M. Soto, F. S. Vom Saal, W. V. Welshons, R. T. Zoeller and J. P. Myers (2012). "Hormones and Endocrine-Disrupting Chemicals: Low-Dose Effects and Nonmonotonic Dose Responses." Endocrine Reviews.

Vandenberg, L. N., R. Hauser, M. Marcus, N. Olea and W. V. Welshons (2007). "Human exposure to bisphenol A (BPA)." Reprod Toxicol 24(2): 139-177.

Vistoli, G., D. De Maddis, A. Cipak, N. Zarkovic, M. Carini and G. Aldini (2013). "Advanced glycoxidation and lipoxidation end products (AGEs and ALEs): an overview of their mechanisms of formation." Free Radic Res 47 Suppl 1: 3-27.

Volkel, W., T. Colnot, G. A. Csanady, J. G. Filser and W. Dekant (2002). "Metabolism and kinetics of bisphenol a in humans at low doses following oral administration." Chem Res Toxicol 15(10): 1281-1287.

Vrooman, L. A., J. M. Oatley, J. E. Griswold, T. J. Hassold and P. A. Hunt (2015). "Estrogenic exposure alters the spermatogonial stem cells in the developing testis, permanently reducing crossover levels in the adult." PLoS Genet 11(1): e1004949.

Wang, X., W. Bao, J. Liu, Y. Y. OuYang, D. Wang, S. Rong, X. Xiao, Z. L. Shan, Y. Zhang, P. Yao and L. G. Liu (2013). "Inflammatory Markers and Risk of Type 2 Diabetes A systematic review and meta-analysis." Diabetes Care 36(1): 166-175.

Watanabe, H., R. Adachi, K. Kusui, A. Hirayama, T. Kasahara and K. Suzuki (2003). "Bisphenol A significantly enhances the neutrophilic differentiation of promyelocytic HL-60 cells." International Immunopharmacology 3(12): 1601-1608.

Welshons, W. V., S. C. Nagel and F. S. vom Saal (2006). "Large effects from small exposures. III. Endocrine mechanisms mediating effects of bisphenol A at levels of human exposure." Endocrinology 147(6 Suppl): S56-69.

West, R. J., P. A. Goodwin and G. M. Klecka (2001). "Assessment of the ready biodegradability of Bisphenol A." Bull Environ Contam Toxicol 67(1): 106-112.

Wetherill, Y. B., B. T. Akingbemi, J. Kanno, J. A. McLachlan, A. Nadal, C. Sonnenschein, C. S. Watson, R. T. Zoeller and S. M. Belcher (2007). "In vitro molecular mechanisms of bisphenol A action." Reprod Toxicol 24(2): 178-198.

Williams, K., J. Christensen and K. Helin (2012). "DNA methylation: TET proteins-guardians of CpG islands?" EMBO Rep 13(1): 28-35.

Wu, H. J., C. Liu, W. X. Duan, S. C. Xu, M. D. He, C. H. Chen, Y. Wang, Z. Zhou, Z. P. Yu, L. Zhang and Y. Chen (2013). "Melatonin ameliorates bisphenol A-induced DNA damage in the germ cells of adult male rats." Mutat Res 752(1-2): 57-67.

Xu, R., C. Chi, F. Li and B. Zhang (2013). "Immobilization of horseradish peroxidase on electrospun microfibrous membranes for biodegradation and adsorption of bisphenol A." Bioresour Technol 149: 111-116.

Yager, J. D. (2015). "Mechanisms of estrogen carcinogenesis: The role of E2/E1-quinone metabolites suggests new approaches to preventive intervention--A review." Steroids 99(Pt A): 56-60.

Yang, Y. J., Y. C. Hong, S. Y. Oh, M. S. Park, H. Kim, J. H. Leem and E. H. Ha (2009). "Bisphenol A exposure is associated with oxidative stress and inflammation in postmenopausal women." Environmental Research 109(6): 797-801. 
Yoshihara, S., M. Makishima, N. Suzuki and S. Ohta (2001). "Metabolic activation of bisphenol A by rat liver S9 fraction." Toxicol Sci 62(2): 221-227.

Yoshihara, S., T. Mizutare, M. Makishima, N. Suzuki, N. Fujimoto, K. Igarashi and S. Ohta (2004). "Potent estrogenic metabolites of bisphenol A and bisphenol B formed by rat liver S9 fraction: their structures and estrogenic potency." Toxicol Sci 78(1): 50-59.

Zalko, D., A. M. Soto, L. Dolo, C. Dorio, E. Rathahao, L. Debrauwer, R. Faure and J. P. Cravedi (2003). "Biotransformations of bisphenol A in a mammalian model: answers and new questions raised by low-dose metabolic fate studies in pregnant CD1 mice." Environ Health Perspect 111(3): 309-319.

Zhang, Q., X. Xu, T. Li, Y. Lu, Q. Ruan, Y. Lu, Q. Wang, F. Dong, Y. Yang and G. Zhang (2014). "Exposure to bisphenol-A affects fear memory and histone acetylation of the hippocampus in adult mice." Horm Behav 65(2): 106-113.

Zoeller, R. T., R. Bansal and C. Parris (2005). "Bisphenol-A, an environmental contaminant that acts as a thyroid hormone receptor antagonist in vitro, increases serum thyroxine, and alters RC3/neurogranin expression in the developing rat brain." Endocrinology 146(2): 607-612. 


\section{Anexos}

\subsection{Ficha do Aluno}

Fanus - Sistema Administrativo da Pós-Graduação

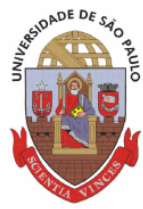

Universidade de São Paulo

Faculdade de Ciências Farmacêuticas

Documento sem validade oficial

FICHA DO ALUNO

9141 - 6726185/2 - André Luiz Teroso
Email:
Data de Nascimento:
Cédula de Identidade:
Local de Nascimento:
Nacionalidade:
Graduação:
Mestrado:
Curso:
Programa:
Data de Matrícula:
Início da Contagem de Prazo:
Data Limite:
Orientador:
Proficiência em Línguas:
Prazo para Realização do Exame
de Qualificação:
Data de Aprovação no Exame de
Qualificação:
Data do Depósito do Trabalho:
Banca:
Data de Aprovabalho:
Data Máxima paro da Defesa:
Raltado da Defesa:
Dana Aprovação da
Defesa:
Danca:
Data

Resultado da Defesa:

Histórico de Ocorrências:
Doutorado

Toxicologia e Análises Toxicológicas

$10 / 06 / 2011$

$10 / 06 / 2011$

$10 / 06 / 2015$

Prof(a). Dr(a). Ana Paula de Melo Loureiro - 10/06/2011 até o presente. E.Mail: apmlou@usp.br

Inglês, Aprovado em 10/06/2011

$04 / 09 / 2013$

Aluno matriculado nas normas vigentes a partir de 01/07/2009

Última ocorrência: Matrícula de Acompanhamento em 18/02/2013 
Fanus - Sistema Administrativo da Pós-Graduação

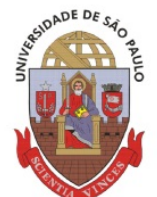

Universidade de São Paulo

Faculdade de Ciências Farmacêuticas

Documento sem validade oficial

FICHA DO ALUNO

\section{1 - 6726185/2 - André Luiz Teroso Ribeiro}

\begin{tabular}{|c|c|c|c|c|c|c|c|c|c|}
\hline Sigla & Nome da Disciplina & Início & Término & $\begin{array}{l}\text { Carga } \\
\text { Horária } \\
\end{array}$ & Cred. & Freq. & onc & Exc. & Situação \\
\hline $\begin{array}{l}\text { FBC5803- } \\
1 / 4\end{array}$ & $\begin{array}{l}\text { Sistemas da Garantia da Qualidade em } \\
\text { Laboratórios Analíticos }\end{array}$ & 09/08/2011 & 1 22/08/2011 & 30 & 2 & 75 & A & $\mathrm{N}$ & Concluida \\
\hline $\begin{array}{l}\text { FBC5784- } \\
2 / 6\end{array}$ & Tópicos Avançados em Toxicologia ॥ & 09/08/2011 & 1 29/11/2011 & 30 & 0 & 0 & - & $\mathrm{N}$ & $\begin{array}{l}\text { Matrícula } \\
\text { cancelada }\end{array}$ \\
\hline $\begin{array}{l}\text { TNM5791- } \\
2 / 2\end{array}$ & $\begin{array}{l}\text { Metodologia da Pesquisa Cientifica (Instituto de } \\
\text { Pesquisas Energéticas e Nucleares - } \\
\text { Universidade de São Paulo) }\end{array}$ & $13 / 09 / 2011$ & 1 05/12/2011 & 60 & 4 & 75 & B & $\mathrm{N}$ & Concluida \\
\hline $\begin{array}{l}\text { FBC5800- } \\
4 / 1\end{array}$ & $\begin{array}{l}\text { Temas Avançados em Ciências e Tecnologia } \\
\text { Farmacêutica I }\end{array}$ & $17 / 10 / 2011$ & 1 23/10/2011 & 30 & 2 & 100 & A & $\mathrm{N}$ & Concluida \\
\hline $\begin{array}{c}\text { FBC5813- } \\
3 / 1\end{array}$ & $\begin{array}{l}\text { Aplicações de Cromatografia em Análises } \\
\text { Toxicológicas }\end{array}$ & $27 / 02 / 2012$ & 2 04/04/2012 & 60 & 4 & 80 & A & $\mathrm{N}$ & Concluida \\
\hline $\begin{array}{l}\text { FBC5784- } \\
2 / 7\end{array}$ & Tópicos Avançados em Toxicologia II & 06/03/2012 & $26 / 06 / 2012$ & 30 & 2 & 90 & A & $\mathrm{N}$ & Concluida \\
\hline $\begin{array}{l}\text { FBC5748- } \\
3 / 3\end{array}$ & Trabalhos Cientificos: da Elaboração à Publicação & $24 / 04 / 2012$ & 2 05/06/2012 & 60 & 4 & 90 & A & $\mathrm{N}$ & Concluida \\
\hline $\begin{array}{l}\text { Atividade } \\
\text { do } \\
\text { Programa }\end{array}$ & $\begin{array}{l}\text { Participou da Etapa de Estágio Supervisionado em } \\
\text { Docência do Programa de Aperfeiçoamento de } \\
\text { Ensino junto à Disciplina FBC0 } 425 \text { Toxicologia } \\
\text { Geral I, ministrada aos alunos de graduação do } \\
\text { curso de Farmácia-Bioquímica da Faculdade de } \\
\text { Ciências Farmacêuticas da Universidade de São } \\
\text { Paulo (1) }\end{array}$ & $01 / 07 / 2012$ & 2 30/11/2012 & - & 3 & 0 & - & - & - \\
\hline
\end{tabular}

\begin{tabular}{|c|c|c|c|}
\hline & \multicolumn{2}{|c|}{ Créditos mínimos exigidos } & \multirow[t]{2}{*}{ Créditos obtidos } \\
\hline & Para exame de qualificação & Para depósito de tese & \\
\hline Disciplinas: & 10 & 20 & 21 \\
\hline \multicolumn{4}{|l|}{ Estágios: } \\
\hline Total: & 10 & 20 & 21 \\
\hline
\end{tabular}

Créditos Atribuídos à Tese: 167

\section{Observações:}

1) Créditos atribuídos de acordo com o disposto na Portaria GR-3588 e GR-4391 - PAE, de 31.08 .09 e aprovados pela Comissão de Pós-Graduação, em Sessão de 15/05/2013.

\section{Conceito a partir de 02/01/1997:}

A - Excelente, com direito a crédito; B - Bom, com direito a crédito; C - Regular, com direito a crédito; R - Reprovado; T Transferência.

Um(1) crédito equivale a 15 horas de atividade programada. 


\subsection{Currículo Lattes}

(9) curriculu Lattes

André Luiz Teroso Ribeiro

Endereço para acessar este CV:http: //lattes.cnpq br/4163660610117459

Última atualizaçăo do curiculo em 29/09/2015

Resumo informado pelo autor

Possui graduação em Farmácia e Bioquímica pela Universidade Paulista (2008) e mestrado em Toxicologia e Análises Toxicológicas pela Universidade de Säo Paulo (2011), atuou principalmente nos seguintes temas: imunotoxicologia, toxicologia ambiental e inflamaçăo pulmonar. Atualmente é doutorando no departamento de Análises Clínicas e Toxicológicas da Universidade de Säo Paulo, atuando principalmente com avaliação de parâmetros relacionados a genotoxicidade condicionada a exposição à xenobióticos presentes no meio ambiente, identificação e quantificaçăo de lesöes em DNA por LC-MS/MS. Atua também como analista antidoping no Departamento de Controle e Pesquisa Antidopagem do Jockey Club de Säo Paulo.

(Texto informado pelo autor)

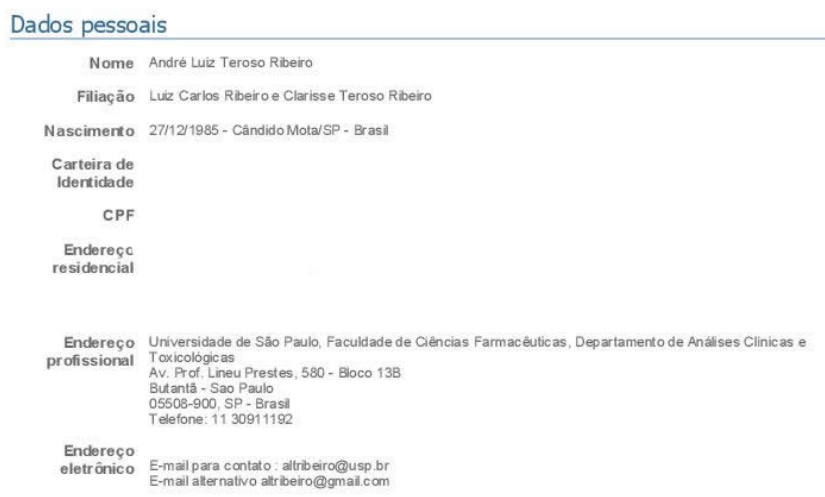

Formação acadêmica/titulação

2011 Doutorado en Toxicalogia e Analises Toxicologicas
Universidade de Såo Paulo, USP, Sao Paulo, grasi

Titulo: Caracterizaçăo de uma nova via metabobilca de biotrasnformaç ăo do bisfenol A e quantífic açăo de

lesōes em DNA de células HL-60 e MCF-7

2009 - 2011 Mestrado em Toxicologia e Analises Toxic clogicas

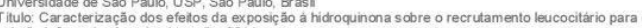

Orientador: Sandra Helena Polisell Farsky (1)

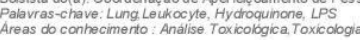

2004 - 2008 Graduaçăo em Farmácia e Bioquimica
Universidade Paulsta, UNIP, Sao Paulo, Bras

Formação complementar
2011 - 2011 Curso de curta duraçắ em Avaliacắo de Risco.
Sociedade Brasliera de Toxicologia, SBTOx, Sao Paulo, Brasil
2011 - 2011 Curso de curta duraçăo em Manus eio transporte e descarte de res iduo quimico
2011 - 2011 Curso de curta duraçăo em Epigenetica:
Universidade de Săo Paulo, USP, Sac Paulo, Brasi

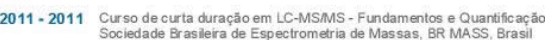
2009 - 2009 Escoda de Atos Estudos em Toxicologia.
Universidade de Săo Paulo, USP, Sao Paulo, Brasi

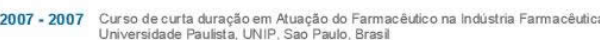




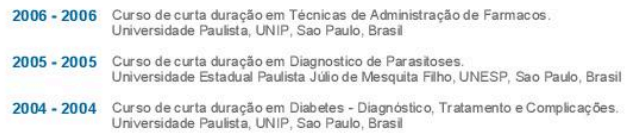


Palavras-chave: Weight of evidence,., Evidence-based Toxicology, BisphenolA, Integrated Testing Strategies : Andise Toxiogibge

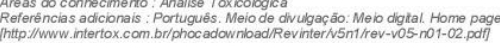

3. Ludwig, K M. RIBEERO, A. L.T., CONTE, A.C. DECLEVA, D.V. L., RIBERO, J. T. D. instituto de Ciencias da Saude (UNIP) v . 30, p. 271-276-,2012.

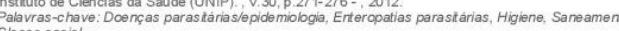

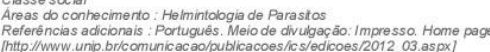

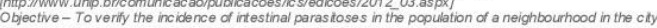
of Candio Mda-SP, and the possibitity of as sociation between parastosis condtions and santation and where basic santation condtions, personal hygiene and educational level of the individual are cracariaveas which may favour transmission. Methods - The collections were made in residences and the faecess were

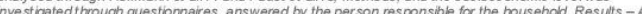
lotal of 177 samples were analysed and $35 \%$ of them were postive for one or more types of parasites, and

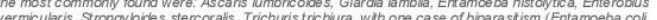
with Ancybstomidae) and the youngest age range was the most affected. Of the studied population $69 \%$ claimed not to have or have vern ititie knowledge of enteropara sitioses. Conclusion- Most of the population precarious personal, envirormental and residential hygiene, and litite knowledge of enteroparastosics.

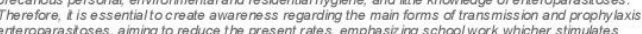
erteroparastoses, aiming to reduce the pres
ervivormertal and presonal hygliene habts.

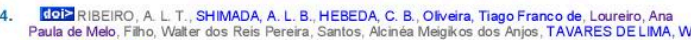
FARSKY, S. H. P.
In vivo yydroquine exposure alters circulating neutrophil activities and impairs LPS-induced lung Palavras-chave: Lung Leukocyte, Hy droquinone, LPS

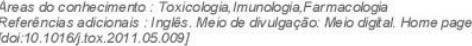

Trabalhos publicados em anais de eventos (resumo)

1. RIBERRO, A. L.T., SANTOS, F. A, OLIVEIRA, A.A. F, de OLIVERA, T. F, LOURERO, A.PM.
BPA EXPOSURE DISRUPTS BONEMARROW CEL COUNT IN VIVO AND INDUCESOXIDATIVE STRESS AND EPIGENETIC ALT RRATIONS IN VITRO In: XVIII Congresso Brasierio de Toxicologia, 2013, Porto Alegre AnIII CBTOX, 2013

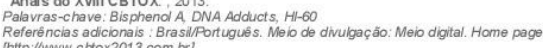

RIBEIRO, A. L.T., de OLIVEIRA, T. F. LOURERO, A.P.M Congress, Society for Free Radical Biology and Medicine, South American Group. 2013, 2013, Buenos

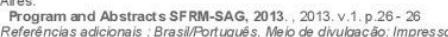

3. RIBEIRO. A T de OLVEIRA T F LOURERO APM

EPIGENETIC ALTERATIONS AND TOXICITY INDUCED BY BISPHENOL A ON HL-GOAND MCF-7 CELLS LINES In: Artioxidants and Redox Process in Heath, 2013, Säo Paulo. Palavras-chave: Bisphenol A DNA Adducts MCE-7 Cets

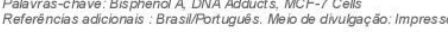

4. SANTOS, F. A. DURAO, A. C. S., SILVA, A. M. O., RIBEIRO, A. L. T., OLIVEIRA, A. A. F., de OLIVERA, T. V. LOULREIRO, A.PM. Semana Universtánia Paulista de Farmácia e Bioquimica. Simposio Anual de Pesquisa em Ciências

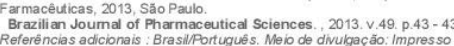

5. SANTOS, F. A. LOIOLA, J. F., OLIVERA, A. A. F., DURAO, A. C. S., MARCOURAKIS, T., SILVA, A. M EVALUATION OF OXIDATIVE AND GLYCATION DAMAGE INA MODEL OF DIABETIC RATS I Antioxidants and Redox Process in Health, 2013, Sä. Paulo.
Program and Abstracts ARPH 2013, 2013. v.1. p.69-69.

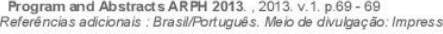

6. SANTOS, F. A., DURAO, A.C. S., MARCOURAKIS, T, SILVA, A. M. O., OLIVERA, A. A. F. de OLIVEIRA, T.F, RIBEIRO, A. L.T., LOUREIRO, A.PM M M M OF OF DIABETIC RATS In: XVII OXIDATIVEAND ADVANCED GLYCATION DAMAGE INA AN

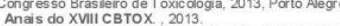

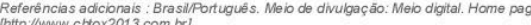

7. SANTOS, F. A. OLIVEIRA, A. A. F. RIBEIRO, A. L.T. DURAO, A. C. S., SILVA, A.M. O. MARIATIVESTRESS INELAMMATION AND ADVANCED GLYCATION AS DAMAGE PATHWAYS IN A
MODEL OF EXPERIMENTAL DIABETES In VIII International Congress, Society for Free Radical Biology and Medicine, South American Group, 2013, 2013 , Buenos Aires.
Program and Astracts SFRM-SAG, 2013 , 2013. v.1. p.91-91

8. RIBEIRO, A. L. T. LOUREIRO, A.P.M
TOXICTYY OF BISPHENOLA (BPA) AND 3-NITROBISPHENOL A (NITRO-BPA) TO HL-60 AND MCF-7 Ciências Farnates

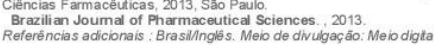

9. RIBERRO, A. L.T., Lourero, Ana Paula de Melo
EVIDENCES OF TOXICTTY YNDUCE BY BISPHENOLA EXPORSURE AT LOWCONCENTRATION ON HL-60 CELLS In: XIIIECOTOX, 2012, Portode Gallnhas. 2012. Journal of the Brazilian Society of Ecotoxicol
Palavras-chave: Bisphenol A DNA Adducts, Hll-60

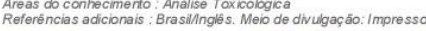

10. SHIMADA, A. L. B. RIBEIRO, A. L. T. HEBEDA, C. B., BOLONHEIS, S. M., Lino dos Santos Franco, A. TAVARES DE L LMA, W. FARSKY, S. H. P. P.
Effects of hydroquinone inhalation on functions of tracheal tissue In: XV Semana Farmacêutica de Ciència e Tecnologia, 2010, Săo Paulo.
Brazilian Joumal of Pharmaceutical Sciences. Săo Paulo: Faculdade de Ciências Farmacêuticas da USP, 2010. v.46. p.43-

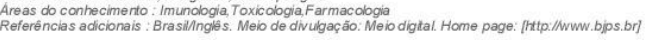




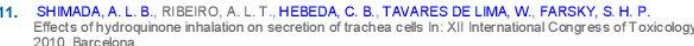

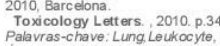
Palavras-chave: Lung Le Lukocyte, Hydroquinone, LPS, Trachea Areas do conhecimerto: Imunologia Toxicologia Farmacologia
Referénncias adicionais : Espanhalingliss. Meio de divulgaçäo: Impresso

12. RIBEIRO, A. L. T., SHIMADA, A. L. B., HEBEDA, C. B., BOLONHEIS, S. M. TAVARES DE LIMA, W
FARSKY, S. . P. In vivo hydroquinone exposure affects leukocyte recrutment and achesion molecules expres sion on LPS Brazilian Journal of Pharmaceutical Sciences. Săo Paulo: Faculdade de Ciências Farmacêuticas da USP, $2010 . v .46 . p .59-59$
Palavras-chave: Ling Leukocyte, Hydroquinone, LPS

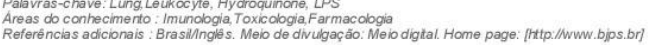

13. RIBEIRO, A L. T. SHIMADA, A. L. B. HEBEDA, C. B. TAVARES DE LIMA, W. FARSKY, S. H. P. INHALED HYDROQUINONE AFFECTS LEUKICYTERECRUITMENT INTO LUNG AND ADHES
MOLECULES EXPRESSION In. XIII International Congress of Toxicology, 2010, Barcelona.

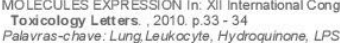

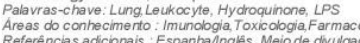

14. RIBEIRO, A. L. T., SHIMADA, A. L. B., SILVA, P. C. B., HEBEDA, C. B., TAVARES DE LIMA, W. FARSKY, Effects of Inhalation of Hydroquinone on Lung Leukocyte Recrultment induced by LPS In: XIV Semana

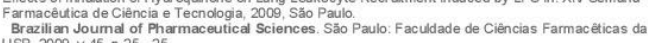

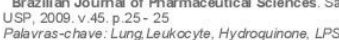

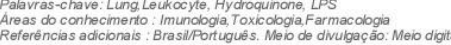

15. RIBEIRO, A. L. T., SHIMADA, A. L. B., HEBEDA, C. B. TAVARES DE LIMA, W. FARSKY, S. H. P. Effects of inhalation of Hyddroquinone on Phagocitic and Fungicidal Activities on Alveolar Macrophages in. XVI Congresso Brasierro de Toxicologia, 2009 B Belo Horizonte.
Revista Brasileira de Toxicologia Säo Paulo: Sociedade Brasiera de Toxicologia, 2009. v.22. p. 220 Revista Brasileira de Toxicologia Săo Paulo: Sociedade Braster, de
220
Palavras-chave: Aveolar, Phagoctic, Macrophages, hydroquinone

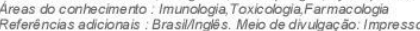

16. SHIMADA, A. L. B., RIBEIRO, A. L. T., SILVA, P. C. B., HEBEDA, C. B., TAVARES DE LIMA, W. FARSKY,

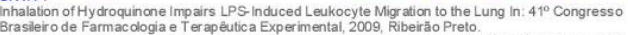
$41^{\circ}$ Congresso Brasileiro de Farmacologia e Terapêutica Experimental. Riber ăo Preto.', 2009 Palavras-chave: Lung Le Lukocyle, Hy droquinone, LPS

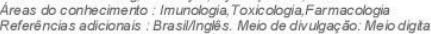

17. Ut RIBEIRO,A.L.T.

政 Enc ontro de Inicicaçăo Cientifíca- UNIP, 2008, Săo Paulo. Educaçăo Dighal - UNIIP, 2008 incidéncia Cândido Mota Setores de atividade. Saude e Senvicicos Sociais

18. CONTE, A.C., RIBEIRO, A. L. T. ARAUJO, J., MONTEQUESE, A.

E Educ ativas In EBA VII Encontro de Biociencias e biotecnolog
CD de divulgaçấo do EBBA, 2005

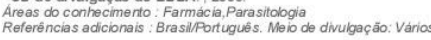

Apresentação de trabalho e palestra

1. RIBEIRO, A. L. T. ATALLAH, P.M.

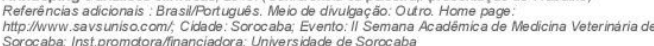
RIBEIRO, A. L. T., ATALLAH, P.M.

Controle Antidopagem nos Esportes Equestres, 2015. (Confere encia ou palestra, Apresentaçăo de Palaviras-chave: Articopagem, Esporte Equestre
Areas do conhecimerto :Zodogia

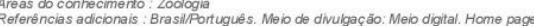

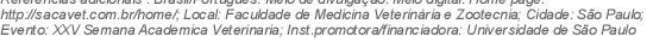

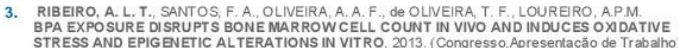
Palavras-chave: Bisphenol A, Hi-O0, DNA Adducis

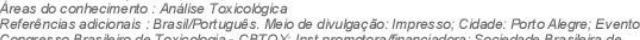

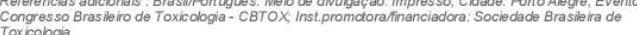

RIBEIRO, A. L. T. SHIMADA, A. L. B., HEBEDA, C. B. Olveria, Tiago Franco de Loureiro, Ana Paula de
Melo, Santos, Alcinea Meigkos dos Anjos, Filho, Water dos Reis Pereira, Lima, Wothan Tavares de.

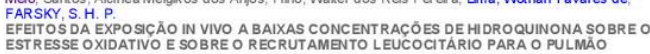
ESTRESSE OXIDATIVO E SO BRE O REC RUTAMENTO LEUCOCCITARI
INFLAMADO, 2011. (Conferéncia ou palestra.Apresentaçáo de Trabalho)

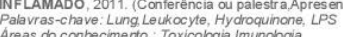

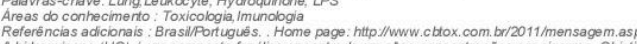

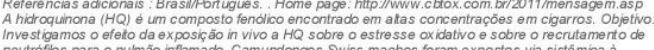

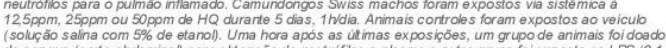

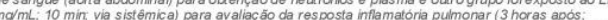

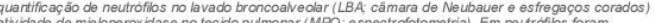

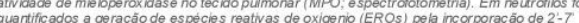

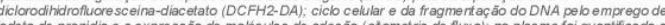

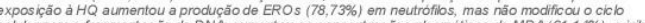

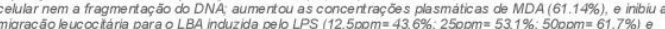

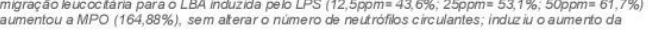




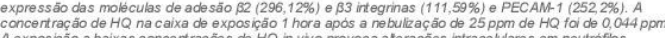

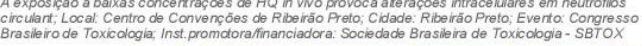

5. RIBEIRO, A L T. SHIMADA, A. L. B. HEBEDA, C. B. Olveira, Tiago Franco de Loureiro, Ana Paula de
Melo, Filho, Watter dos Reis Pereria, Santos, Alcinea Meigikos dos Anjos, Lima, Wahan Tavares de,

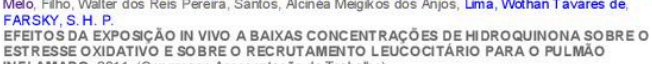
INFLAMADO, 2011. (Congresso. Apresentac ắa de Trab L
Palavras-chave: Lurg Leukocyte, Hydroguinone. LPS

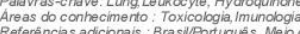

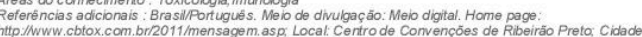

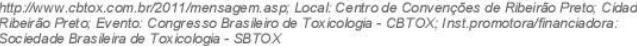

6. RIBEIRO, A. L.T.

(Conferência ou palestra Apresentaçăa de Trabatho

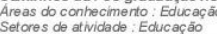

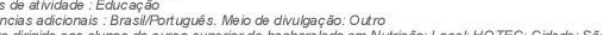

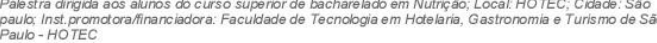

7. SHIMADA, A. L. B., RIBEIRO, A. L. T. HEBEDA, C. B. BOLONHEIS, S. M., Lino dos Santos Franco, A. TAVARES DE LIMA, W. FARSKY, S. H. P. PATON ON FUNCTIONS OF TRACHEAL TISSUE, 2010
EFFECTS OF HYDROQUINONEINHALATIN Palavras-chave: Trachea, Lung, Leukocyte, Hydroquinone, LPS

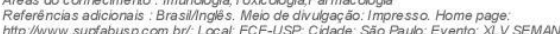

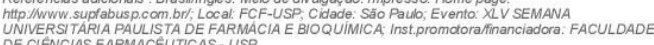

B. II SHIMADA, A. L. B. RIBEIRO, A. L. T. HEBEDA, C. B., BOLONHEIS, S. M. Lino dos Santos Franco, A. TAVARES DE LIMA, W. FARSKY, S. H. P.
Eftects of fHdroquinone Inhalation on Functions of Tracheal Tissue, 2010
(Congresso.Apresentacacáo de Trabaho) Palavras-chave: Trachea, Lung Leukocyte, Hycroquinone, LPS

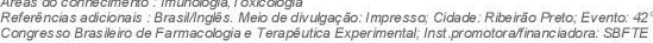

9. SHIMADA, A. L. B, RIBEIRO, A. L. T. HEBEDA, C. B. TAVARES DE LIMA, W. FARSKY, S. H. P.
EFFECTS OF HYDROQUINONEINHALATION ON SECRETION OF TRACHEA CELLS, 2010.

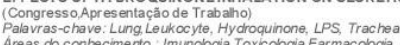

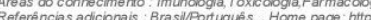

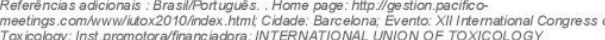

10. RIBEIRO, A. L. T., SHIMADA, A. L. B., HEBEDA, C. B. BOLONHEIS, S. M., TAVARES DE LIMA, W. FARSKY, S.H. P.
IN VIIIO HYDROQUNONE EXPOSURE AFFECTS LEUKOCYTE RECRUITMENT AND ADHESION
MOLECULES EXPRESSION ON LPS INFLAMED LUNG, 2010. (Congresso,Apresentaçäo de Trabaho

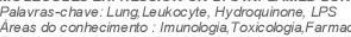

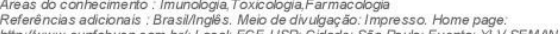

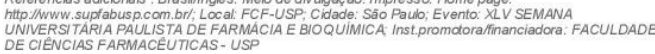

11. A) RIBEIRO, A. L. T. SHIMADA, A. L. B. HEBEDA C. B. TAVARES DE LIMA, W. FARSKY, S. H.P.
INHALED HYDROQUINONEAFECTS LEUKOCYTE RECRUITMENT INTO LUNG AND ADHESIO MOLECULES EXPRESSION, 2010. (Congresso, Apresentaçăo de Trabalho Palaveras-chave: Lung, Leuko conte, Hy droquinone, LPS

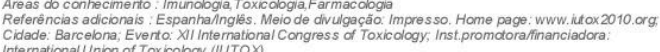

12. RIBEIRO, A. L. T., SHIMADA, A. L. B., LIMA, P. C. B., HEBEDA, C. B., TAVARES DE LIMA, W. FARSKY, EFFECTS OF INHALATION OF HYDROQUINONE ON LUNG LEUKOCYTE RECRUITMENT INDUCED

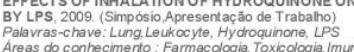

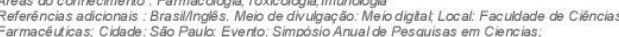

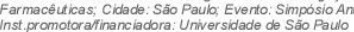

13. I) RIBEIRO, A. L. T. SHIMADA, A. L. B. HEBEDA C. B. TAVARES DE LIMA, W. FARSKY, S. H. P.
EFFECTS OF INHALATION OF HYDROQUINONE ON PHAGOCYTIC AND FUNGICIDAL ACTIVITIES ON ALVEOLAR MACROPHAGES, 2009. (Congresso, Apresentaçăo de Trabaho) Pelaurras-chave: ANveolar, Phagoctic, Macrophagess, Hitroquinon

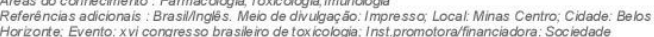

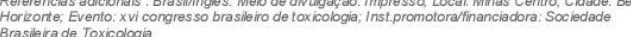

14. SHIMADA, A. L. B. RIBEIRO, A. L. T. LIMA, P. C. B. TAVARES DE LIMA, W. FARSKY, S. H. P.
INHALATION OF HYDROQUINONE IMPAIRS LPS-INDUCED LEUKOCITEMIGRATION TO THE Palavras-chave: Lung, Le uk oc yte, Hy droquinone. LPS

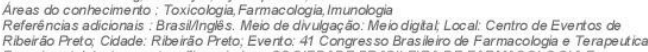

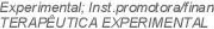

15. RIBEIRO, A L. T., CONTE, A. C. Ludwig, K.M.

(a)

2008. (Outra, Apresentaçăo de Trabalho) Áreas do conhecimento: Parastologia

Setcres de atvidade: Saùde e Servicos Sociais

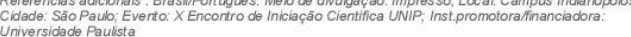

16. Î" RIBEIRO, A. L. T. DECLEVA, D.V. L., CONTE, A.C. Ludwig, K. M
Estudo da incidencia de Entereparasitoses na Cidade de Candido Mota - Estado de São Paulo

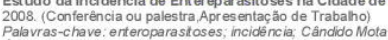
Palavras-chave: erteroparastoses, incilid
Areas do conhecimerto: Parastiogia

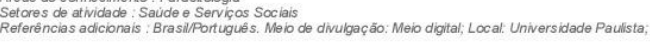


Redes sociais, websites, blogs

1. RIBEIRO, A. L. T., OLIVERA, T. F.
Escola de Invermo em Toxicologia 2012

Palavras-chave: Toxicologia
AAreas do conthecmento Andise Toxicolbgica,Farmácia

Entrevistas, mesas redondas, programas e comentários na midia

1. RIBEIRO, A. L.T.

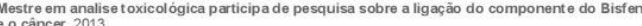

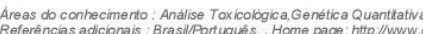

Demais produções técnicas

1. RIBERO, ALT, SHIMADA, ALB, BAIRROS, AV, DREWES, CC, OLIVERA, C D R
ANDREGUETTI, D X et all Escola de Inverno em Toxicologia, 2012 (Extensăo, Curso de curta

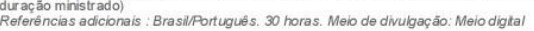

Educação e Popularizaçāo de C\&T

Apresentação de trabalho e palestra

1. RIBERO, A L T ATALAH P. M Controle Antidopagem nos Esportes Equestres, 2015. (Conferência ou palestra.,Apresentaçăo de Trabalho)
Palavras-chave: Artidopagem Esporte Equestre Areas do conhecimento : Zoobog

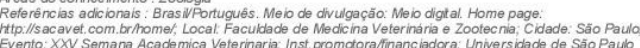

2. RIBERO, A L.T., SANTOS, F. A. OLIVEIRA, A. A. F, de OLIVERA, T. F, LOUREIRO, A.P.M.

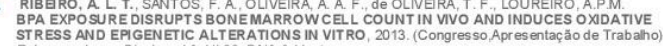

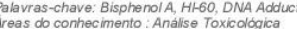
Referéncias adicionais: Brasiliportugués. Meio de divulgacắ: Impresso; Cidade: Porto Alegre: Everto

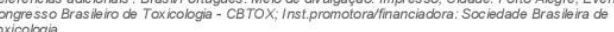

Redes sociais, websites e blogs

1. RIBERO, A L.T., OLVEIRA, T. F.
Escola de Inverno em Toxicologia, 2012. (Site, Midias sociais, websites, blogs) Palavras-chave: Toxicologia Areas do cornhecimento Andilse Toxicoldogica, Farmicia

Orientações e Supervisões

Orientaçöes e supervisōes

Orientações e supervisões concluidas

Trabalhos de conclusão de curso de graduação

1. Gisele Carmelita SiNa Consumo Alimentar de Praticantes de Maratona 2013. Curso (Nutriç̧ăo)Areas do conhecimento : Bioquimica da Nutriçāo, Nutriçâa

Eventos

Eventos

Participação em eventos

1. Conferencista nơ (a) II Semana Acadêmica de Medicina Veterinária de Sorocaba, 2015. (Congresso)

2. Conferencista no(a) XXV Semana Academica Veterinaria, 2015. (Congresso)

3. Avaliador no(a) Feira Brasileira de Ciências e Engenharia - FEBRACE, 2013. (Outra)

4. Apresentaçăo de Poster / Painel no(a) Congresso Brasileiro de Toxicologia - CBTOX, 2013. (COAgresSO)

5. Avaliador no(a) Simpósio Internacional de Iniciaçāo Cientifica da USP, 2012 (Simpósio) 
6. Avaliador no(a) Feira Brasileira de Ciênciae Engenharia - FEBRACE, 2012 (Congresso)

7. Apresentacă ăo de Poster / Painel no(a) XII ECOTOX, 2012 (Congresso)
EVIDENCESOF TOXICITY INDUCED BY BISPHENOL A EXPORSURE AT LOWCONCENTRATION ON

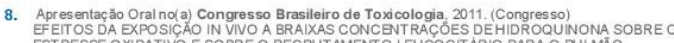
ESTRESSE OXIDATIVO E SOBRE O RECRUTAMENTO LEUCOCITARIO PARA O PULMAO

9. XLVI Semana Universitária Paulista de Farmácia e Bioquímica, 2011. (Congresso)

10. Apresentaçăo de Poster / Painel no(a) XLV SUPFAB - Semana universit tária Paulista de farmácia e IN VIVO HYDROOUINONE EXPOSURE AFFECTS LEUKOCYTE RECRUITMENT AND ADHESION MOLECULES EXPRESSION ON LPS INFLAMED LUNG.

11. Apresentaçăo de Poster / Painel no(a) IUTOX - XII Intermational Congress of Toxicology, 2010 (COngresso)
INHALED HYDOQQUINONE EFFECTS ON LEUKOCYTE RECRUITMENT INTO THE LUNG AND
ADHESONMOLECUES FROM CIRUIATTNG BLOOD

12. Apresentacăo de Poster / Painel no(a) Simpósio Anual de Pesquisas em Ciẻncias, 2009. (Simpósio)
EFFECTS OF INHALATION OF HYROROQUINONE ON LUNG LEUKOCYTE RECRUITMENT INDUCED
BY LPS.

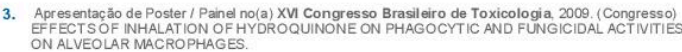

14. Apresentaçăo de Poster / Painel no(a) 41 Congresso Brasileiro de Farmacologia e Terapeutica INHLATION OF HYOROQUUNONE IMPAIRS LPS-INDUCED LEUKOCYTE MIGRATION TO THE LUNG.

15. ESCOLA DE ALTOS ESTUDOS EM TOXICOLOGIA, 2009. (OUtra)

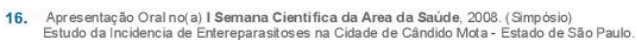

17. Apresentaçăo de Poster / Painel no(a) Semana da Saide, 2007 . (Outra)
Parasitoses Intestinais em escolares: Ocarerencia e Campanhas Eductitivas.

18. XV Congresso Paulista de Farmacéuticos e VII Seminário Internacional de Farmacêuticos, 200 .
(Congresso)

19. Apresentaçăo de Poster / Painel no(a) PARASITOSES INTESTINAIS EM ESCOLARES: Ocorrência EBBA VII Encontro de Biociéncia e Biotecnologia.

20. Apresentaçăo Oral no (a) IJORNADA INTEGRADA DA SAỦDE, 2005 (Encontro)
PARASITOSES INTESTINAIS BM ESCOLARES: Ocorrencia e Campanhas Educativas.

Organização de evento

1. LOURERO, A.P.M. DREWES, C. C. Eler, S.C.W.S. Barioni, ED, OLIVERA, A.A. F., DURAO, A. C. S., Iil Escola de Inverno em Toxicologia - III ETox, 2014. (Outro, Organizaçăo de evento

2. RIBERO, A L. T.
II Escola de Invermo em Toxicologia - II EIT ox 2013. (Outro, Organizaçăo de evento

3. PINTO, E, SHIMADA, A. L. B. RIB BRO, A. L. T., Torres, L. H. L. ALMEIDA, R. M., OLIVEIRA, C. D. R.,

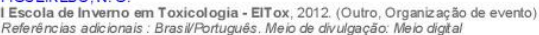

Totais de produção

\section{Produção bibliográfica}

\begin{tabular}{|c|c|}
\hline Artigos completos pubic ados em periodico & 4 \\
\hline Trabalhos pubicicados em anais de eventos & 18 \\
\hline Apresentaçōes de trabahos (Conferência ou palestra) & 5 \\
\hline Apresentaç̄os de trabahlhos (Congresso) & 9 \\
\hline Apresentaçōes de trabahos (Simpósio) & 7 \\
\hline
\end{tabular}

Produção técnica

Curso de curta diraçonisistato(eriensa)

Programa de Rádio ou TV (entrevista)

Orientaçōes

Orientaçắo concluida (trabalho de conclusăo de curso de graduaçăo)

Evertos

Participaçōes em evertos (congresso) 13

Participą̧ öes em eventos (simposio)

Participaçōes em eventos (encontro)

Participaçốes em eventos (outra) 
Outras informações relevantes

1 1) Vice-Representante discente dos alunos de pos-graduaca a do Programa de Analisises Clilinicas e
Toxicologicas na Faculdade de Ciencias Farmaceutic as da Universidade de Sao Paulo. Periodo. Janeiro
2010 - Janeiro 2011 .

Página gerada pelo sistema Curriculo Lattes em 29/09/2015 às 20:15:08 


\subsection{Intrusções para os membros da banca}

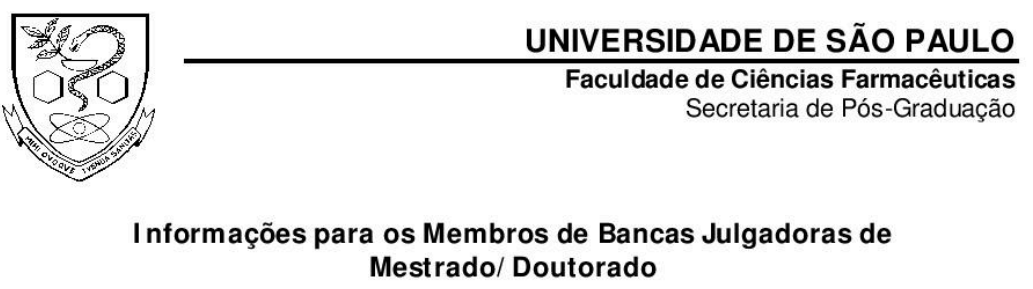

1. O candidato fará uma apresentação oral do seu trabalho, com duração máxima de trinta minutos.

2. Os membros da banca farão a argüição oral. Cada examinador disporá, no máximo, de trinta minutos para argüir o candidato, exclusivamente sobre o tema do trabalho apresentado, e o candidato disporá de trinta minutos para sua resposta.

2.1 Com a devida anuência das partes (examinador e candidato), é facultada a argüição na forma de diálogo em até sessenta minutos por examinador.

3. A sessão de defesa será aberta ao público.

4. Terminada a argüição por todos os membros da banca, a mesma se reunirá reservadamente e expressará na ata (relatório de defesa) a aprovação ou reprovação do candidato, baseando-se no trabalho escrito e na argüição.

4.1 Caso algum membro da banca reprove o candidato, a Comissão Julgadora deverá emitir um parecer a ser escrito em campo exclusivamente indicado na ata.

4.2 Será considerado aprovado o aluno que obtiver aprovação por unanimidade ou pela maioria da banca.

5. Dúvidas poderão ser esclarecidas junto à Secretaria de PósGraduação: pgfarma@usp.br, (11) 30913621.

São Paulo, 23 de maio de 2014.

Prof. Dr. Adalberto Pessoa Junior Presidente da CPG/FCF/USP 
8.4. Certificado da Comissão de Ética no Uso de Animais (CEUA) da FCFUSP

O título desta Tese foi alterado ao final do desenvolvimento do projeto por motivo de clareza. Entretanto, o uso dos animais ocorreu exatamente como descrito no processo aprovado pela Comissão de Ética no Uso de Animais da Faculdade de Ciências Farmacêuticas da USP (certificado apresentado abaixo). 


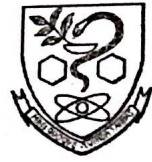

Oficio CEUA/FCF/71/2012

\section{CERTIFICADO}

A Comissão de Ética no Uso de Animais da Faculdade de Ciências Farmacêuticas da Universidade de São Paulo Certifica que o Projeto "CARACTERIZAÇÃO DE UMA NOVA VIA DE BIOTRANSFORMAÇÃO DO BISFENOL A E QUANTIFICAÇÃO DE LESÕES EM DNA DE CÉLULAS HL-60 E MCF-7 E RATOS DIABÉTICOS" (Protocolo CEUA/FCF/369), de responsabilidade do pesquisador André Luiz Teroso Ribeiro, sob a orientação da Profa. Dra. Ana Paula de Melo Loureiro, está de acordo com as normas do Conselho Nacional de Controle de Experimentação Animal - CONCEA e foi APROVADO em reunião de 06 de agosto de 2012.

São Paulo, 06 de agosto de 2012.

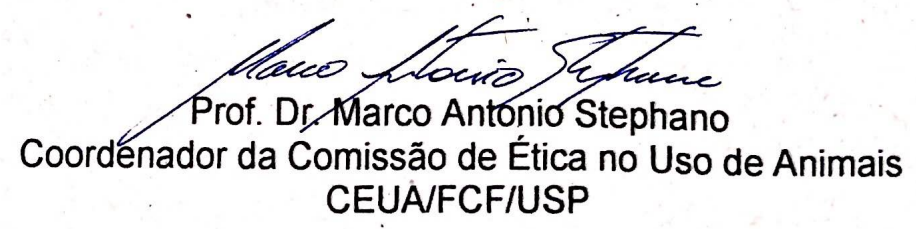

Av. Prof. Lineu Prestes, 580 - Bloco 13 A - Cidade Universitárla - CEP 05508-900 - São Paulo - SP Fone: (11) 3091-3622 I Fax: (11) 3091-3677 - e-mail: ceuafcf@usp.br 